UNIVERSIDADE DE SÃO PAULO

INSTITUTO DE GEOCIENNCIAS

\title{
IMPACTOS DOS SISTEMAS DE SANEAMENTO “IN SITU” NAS ÁGUAS SUBTERRÂNEAS, MUNICÍPIO DE ITAQUAQUECETUBA (SP)
}

\section{RODRIGO DOS SANTOS ESPINDOLA}

Orientador: Dr. Alberto Pacheco

DISSERTAÇÃO DE MESTRADO

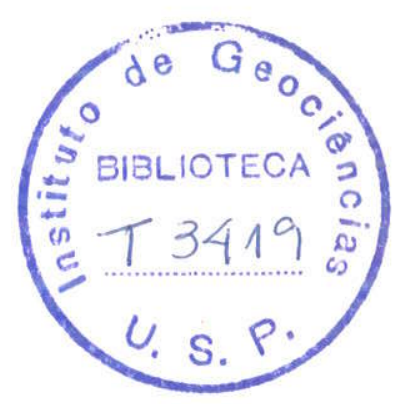

COMISSÃO JULGADORA

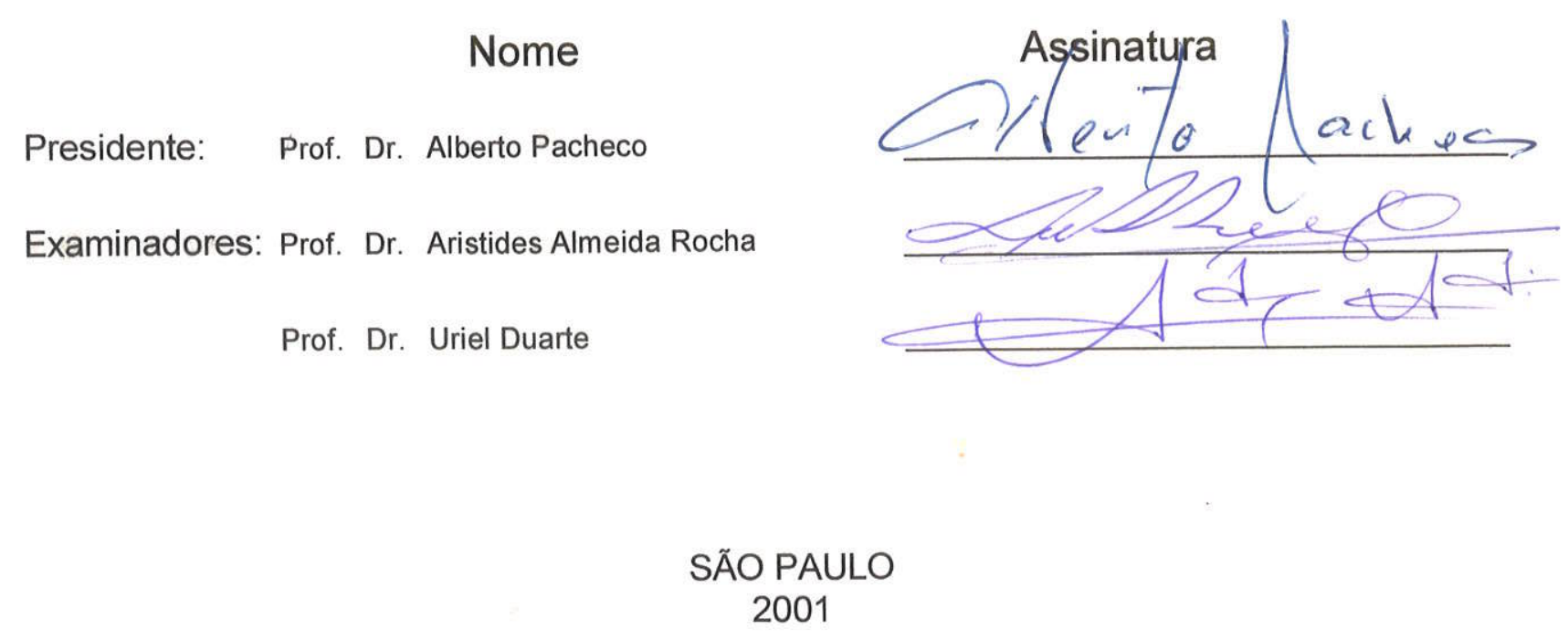


UNIVERSIDADE DE SÃO PAULO

INSTITUTO DE GEOCIÊNCIAS

\section{IMPACTOS DOS SISTEMAS DE SANEAMENTO IN SITU NAS ÁGUAS SUBTERRÂNEAS, MUNICÍPIO DE ITAQUAQUECETUBA (SP)}

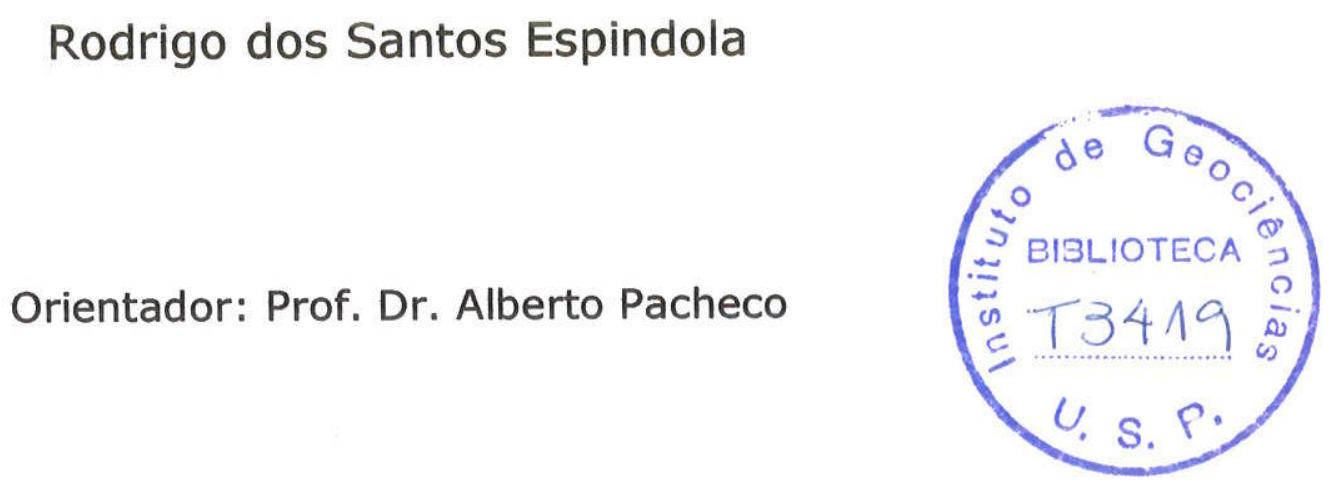

Dissertação de Mestrado

Programa de Pós-Graduação em Recursos Minerais e Hidrogeologia

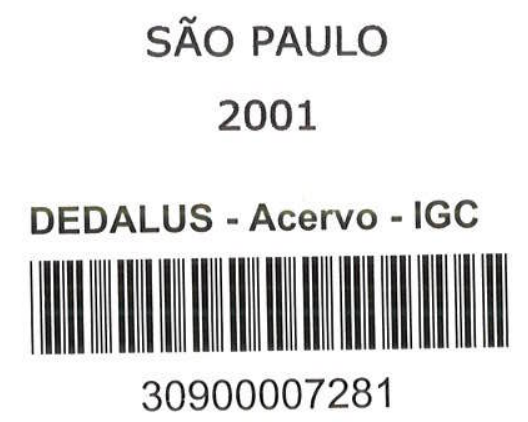




\section{AGRADECIMENTOS}

A realização deste trabalho não seria possivel sem a colaboração de várias instituições e pessoas, às quais o autor expressa sinceros agradecimentos.

Ao Prof. Dr. Alberto Pacheco pela orientação da pesquisa e amizade, desde a época de graduação.

Ao Instituto de Geociências da Universidade de São Paulo (IGc / USP) pela formação acadêmica e especialização científica.

À Fundação de Amparo à Pesquisa do Estado de São Paulo (FAPESP) pela concessão de Auxílio à Pesquisa (Processo No 1996/12.656-5), essencial para a execução deste projeto.

Ao CNPq pela bolsa de estudo na etapa inicial da pesquisa.

Ao Edson Rogério Batello pelo auxílio nos trabalhos de campo e amizade.

Ao Centro de Pesquisas de Águas Subterrâneas (CEPAS / USP), em especial ao Laboratório de Hidroquímica II pela realização das análises químicas.

Ao laboratório CEIMIC Análises Ambientais S/C Ltda. pelas análises químicas realizadas.

Ao Laboratório de Microbiologia Ambiental do Instituto de Ciências Biomédicas da USP, em nome da Prof ${ }^{\mathrm{a}} \mathrm{Dr}^{\mathrm{a}}$ Vivian Pellizari, pela realização das análises microbiológicas.

À Rosa Gamba e Elisa Ciapina pelo apoio e participação nas coletas de água para análises microbiológicas e execução de análises laboratoriais.

Ao William Sallum Filho e José Donizetti de Souza pelo apoio na digitalização de arquivos em AutoCAD ${ }^{\circledR}$. 
Ao Jean Carlos Marcelino, Edval Barbosa da Silva e Jenilton dos Santos pela execução das sondagens a trado e auxílio nos ensaios de permeabilidade.

À Jamile Dehaine pela execução das sondagens elétricas e discussão sobre métodos geofísicos de investigação.

À Sandra Akemi Iwata pela tradução do resumo.

Ao Sérgio Matos pelo apoio.

Aos moradores do bairro Recanto Mônica (área de estudo) pela participação e envolvimento na pesquisa.

Aos meus pais e irmãos pelo incentivo e apoio, em especial ao meu pai, Carlos Roberto Espindola, pelo exemplo científico e profissional.

À minha esposa Elza pelo constante incentivo, principalmente na fase final da pesquisa, agradeço de coração o apoio e o auxílio prestados. 
À Elza, minha esposa, e ao meu filho Rafael. 


\section{ÍNDICE}

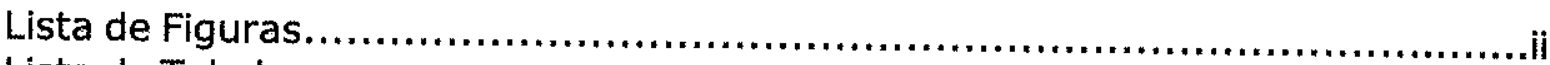

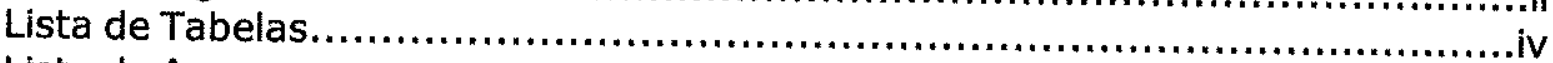

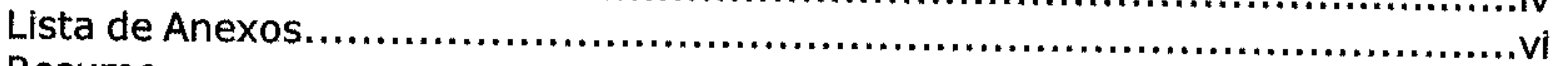

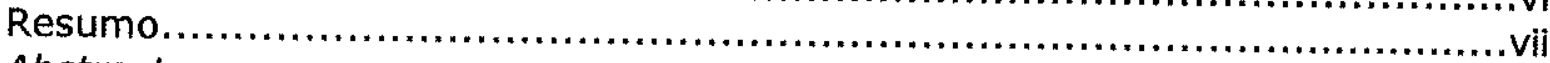

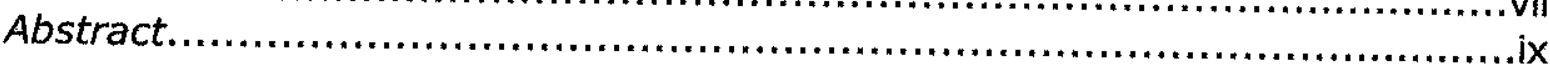

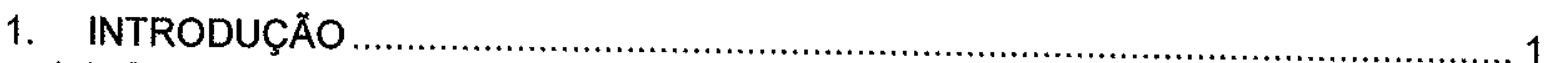

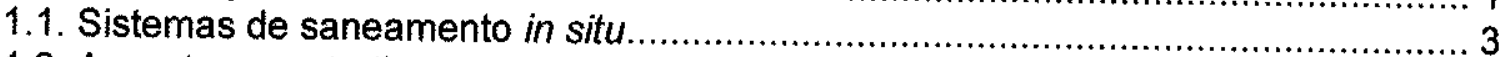

1.2. Aspectos construtivos e tipos de fossas sépticas ................................................. 4

1.3. Aspectos geoquímicos relacionados aos sistemas de saneamento in situ ................ 6

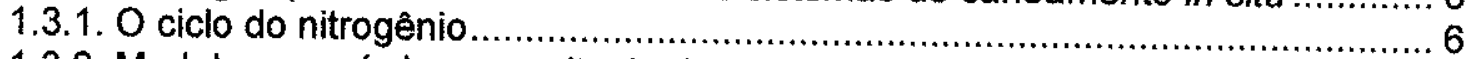

1.3.2. Modelo geoquímico conceitual relacionado às fossas sépticas ....................... 15

1.4. Aspectos microbiológicos relacionados ao esgoto doméstico ................................ 17

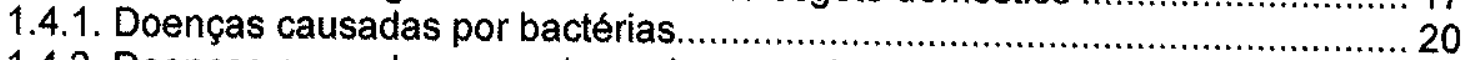

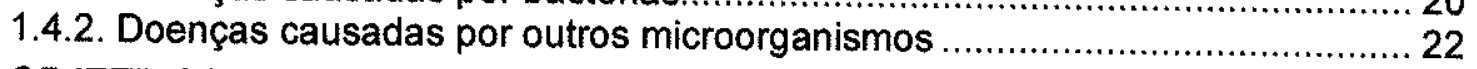

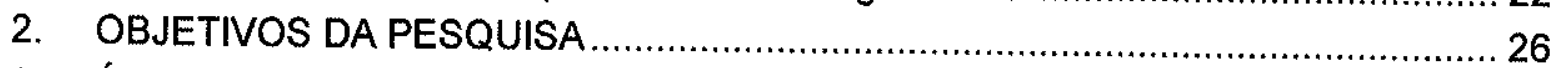

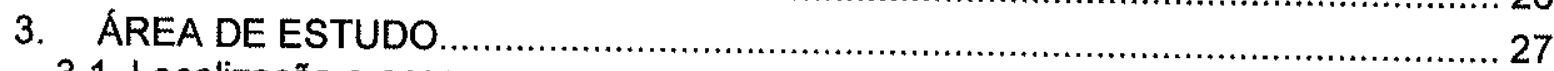

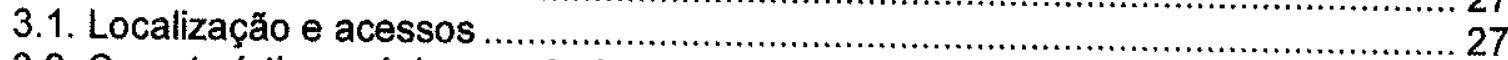

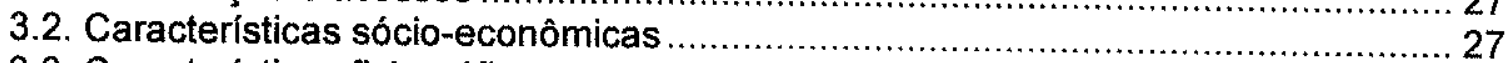

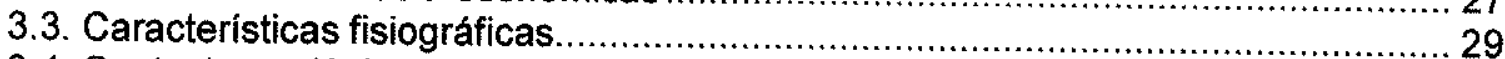

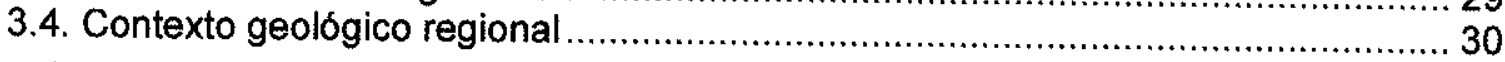

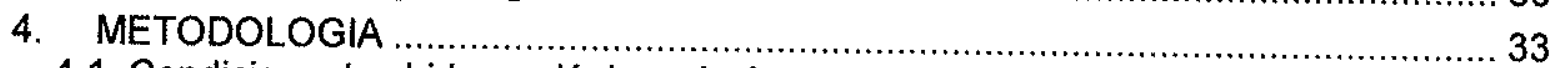

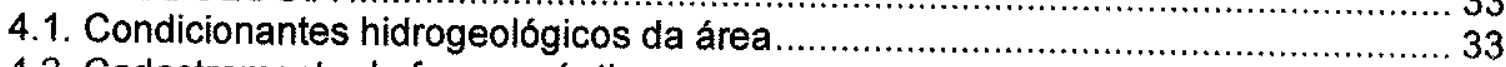

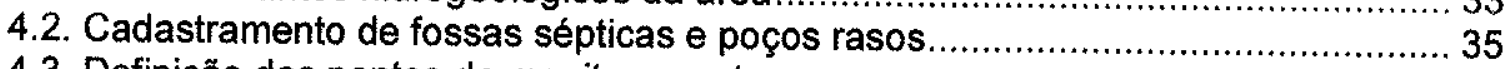

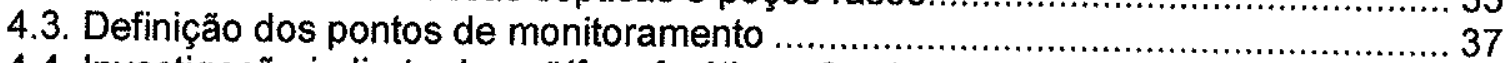

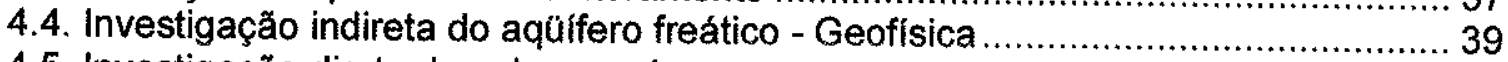

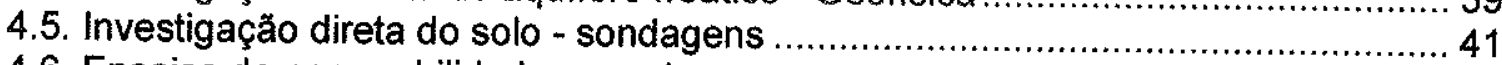

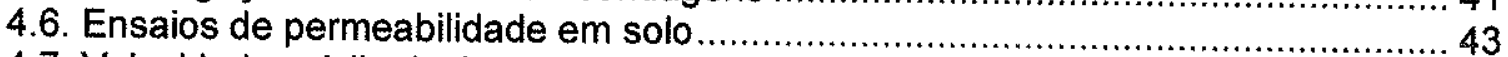

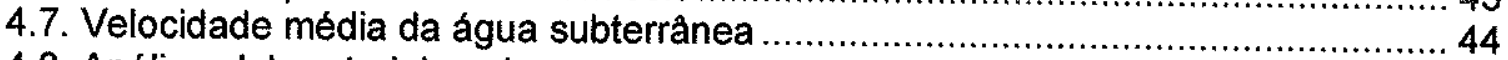

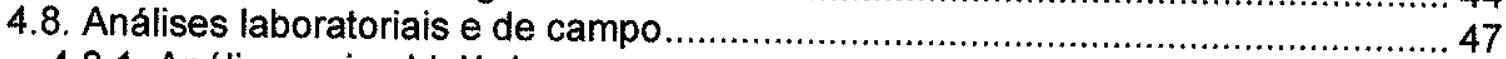

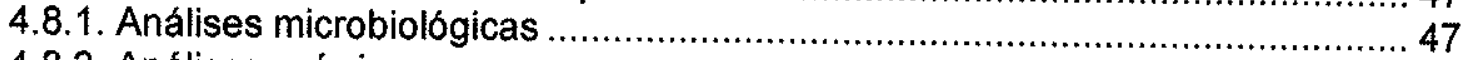

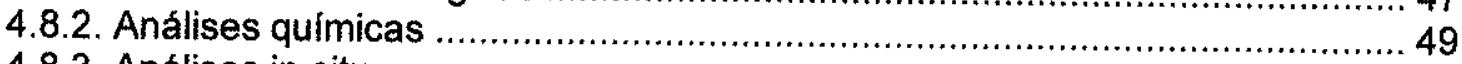

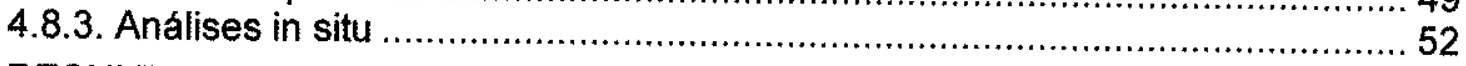

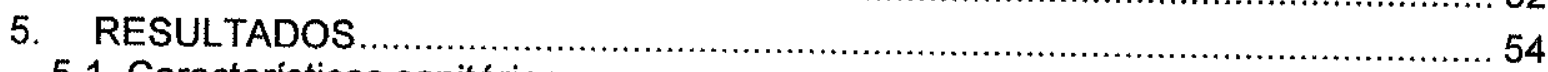

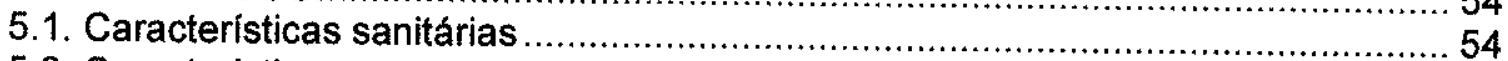

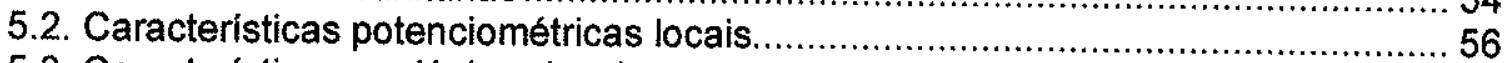

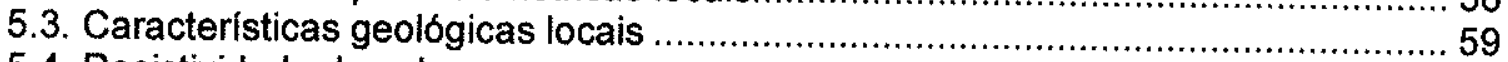

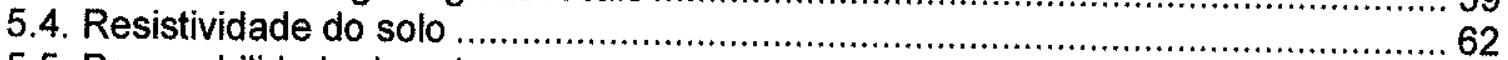

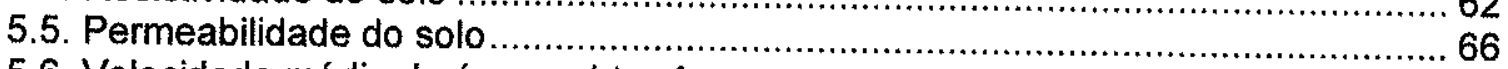

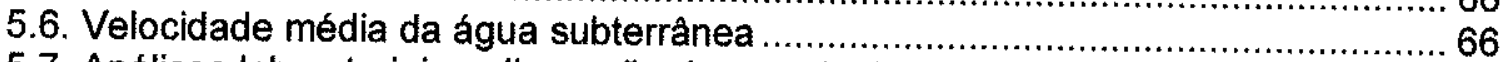

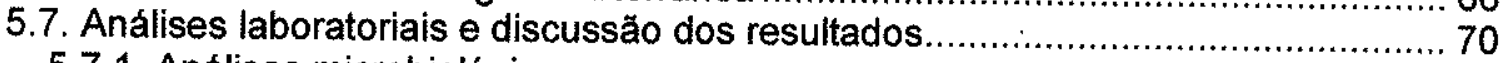

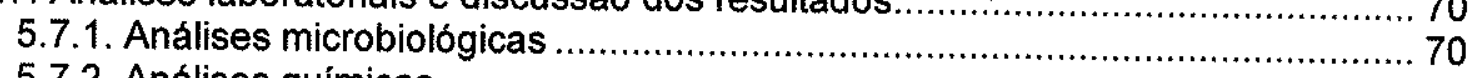

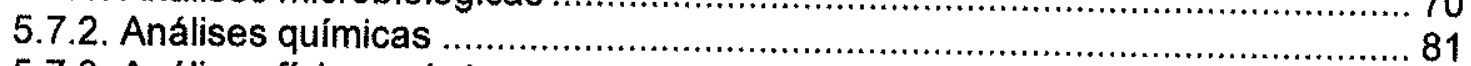

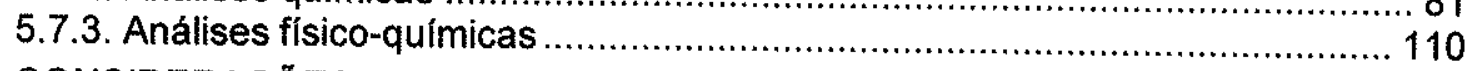

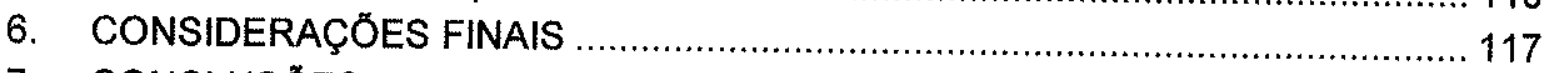

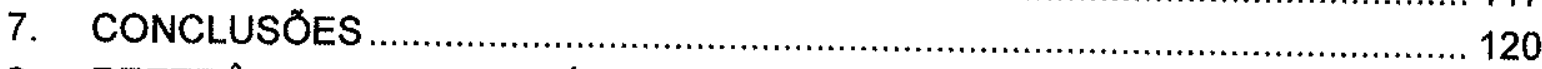

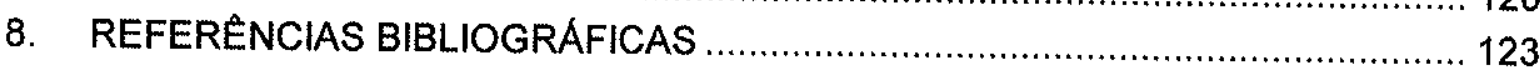




\section{LISTA DE FIGURAS}

Figura 1.1 - Visualização de um sistema de saneamento in situ (Batalha, 1989)

Figura 1.2 - Detalhe da fossa séptica, onde o esgoto é processado (Batalha, 1989)

Figura 1.3 - Fossa seca (a) e fossa negra (b)

Figura 1.4 - Diagrama de óxido-redução das espécies químicas da série nitrogenada (Appelo \& Postma, 1993)

Figura 1.5 - Seqüência de importantes processos de óxido redução ( $\mathrm{pH} 7$ ) em sistemas naturais (Stumm \& Morgan, 1981)

Figura 1.6 - Composição da água subterrânea como reflexo da seqüência de processos redutores (Appelo \& Postma, 1993)

Figura 1.7 - Esquema genérico de uma fossa séptica (Wilhelm et al., 1994)

Figura 1.8 - Modelo conceitual da contaminação da água subterrânea pelo esgoto sanitário doméstico

Figura 3.1 - Localização da área de estudo e principais acessos rodoviários

Figura 3.2 - Principais unidade geológicas que afloram em Itaquaquecetuba

Figura 4.1 - Condicionantes hidrogeológicos do bairro Recanto Mônica

Figura 4.2 - Posicionamento das residências do bairro Recanto Mônica

Figura 4.3 - Poços, fossas e córregos monitorados no bairro Recanto Mônica

Figura 4.4 - Arranjo Schumberger - sondagem elétrica vertical

Figura 4.5 - Representação esquemática do ensaio de rebaixamento

Figura 4.6 - Posicionamento dos ensaios de permeabilidade em solo

Figura 5.1 - Poços e fossas cadastradas no bairro Recanto Mônica

Figura 5.2 - Mapa potenciométrico

Figura 5.3 - Seções geológicas esquemáticas

Figura 5.4 - Posicionamento das sondagens elétricas verticais

Figura 5.5 - Gráficos de rebaixamento do nivel d'água em função do tempo

Figura 5.6 - Variação da concentração de coliformes fecais nos poços monitorados

Figura 5.7 - Variação da concentração de coliformes totais nos poços monitorados 
Figura 5.8 - Variação da concentração de colifagos nos poços monitorados Figura 5.9 - Variação da concentração de cloreto nos poços monitorados

Figura 5.10 - Variação da concentração de fluoreto nos poços monitorados Figura 5.11 - Variação da concentração de nitrato nos poços monitorados Figura 5.12 - Variação da concentração de brometo nos poços monitorados Figura 5.13 - Variação da concentração de fosfato nos poços monitorados Figura 5.14 - Variação da concentração de sulfato nos poços monitorados Figura 5.15 - Variação da concentração de sódio nos poços monitorados Figura 5.16 - Variação da concentração de potássio nos poços monitorados Figura 5.17 - Variação da concentração de cálcio nos poços monitorados Figura 5.18 - Variação da concentração de magnésio nos poços monitorados Figura 5.19 - Variação da concentração de ferro nos poços monitorados Figura 5.20 - Variação da concentração de manganês nos poços monitorados Figura 5.21 - Variação da concentração de alumínio nos poços monitorados Figura 5.22 - Variação da concentração de bário nos poços monitorados Figura 5.23 - Variação da concentração de estrôncio nos poços monitorados Figura 5.24 - Variação de pH nos poços monitorados

Figura 5.25 - Variação de Eh nos poços monitorados

Figura 5.26 - Variação da condutividade elétrica nos poços monitorados Figura 5.27 - Variação da alcalinidade nos poços monitorados 


\section{LISTA DE TABELAS}

Tabela 1.1 - Estimativa da eficiência de uma fossa séptica

Tabela 1.2 - Dimensões de fossas sépticas

Tabela 1.3 - Principais reações biogeoquímicas relacionadas aos sistemas sépticos subterrâneos

Tabela 1.4 - Características morfológicas das bactérias

Tabela 1.5 - Principais estruturas das bactérias

Tabela 1.6 - Nutrição bacteriana

Tabela 1.7 - Principais doenças causadas por bactérias

Tabela 4.1 - Parâmetros analíticos e freqüência de amostragem

Tabela 4.2 - Parâmetros, metodologia e equipamentos analíticos (CEPAS)

Tabela 4.3 - Parâmetros e metodologia analítica (CEIMIC Análises Ambientais)

Tabela 4.4 - Equipamentos utilizados para análises físico-químicas in situ

Tabela 5.1 - Características hidráulicas dos poços cadastrados

Tabela 5.2 - Dados geológico-estruturais medidos em campo

Tabela 5.3 - Síntese dos resultados da investigação geofísica

Tabela 5.4 - Ensaios de Permeabilidade em solo

Tabela 5.5 - Cálculo da velocidade média da água subterrânea nas 05 vertentes estudadas

Tabela 5.6 - Resultados analíticos de coliformes fecais e totais dos 15 poços monitorados - 01 ano hidrológico (NMP/100mL)

Tabela 5.7 - Resultados analíticos de colifagos em 15 poços monitorados (01 ano hidrológico)

Tabela 5.8 - Resultados analíticos de Salmonella e Cryptosporidium em 06 poços monitorados

Tabela 5.9 - Resultados analíticos de coliformes fecais e totais em 02 córregos monitorados 
Tabela 5.10 - Resultados analíticos de Salmonella e Cryptosporidium em 02 fossas monitoradas

Tabela 5.11 - Concentraçăo de ánions na água subterránea dos 15 poços monitorados ( $1^{\circ}$ monitoramento)

Tabela 5.12 - Concentração de ânions na água subterrânea dos 15 poços monitorados ( $2^{\circ}$ monitoramento)

Tabela 5.13 - Concentração de ânions na água subterrânea dos 15 poços monitorados ( $3^{\circ}$ monitoramento)

Tabela 5.14 - Concentração de cátions na água subterrânea dos 15 poços monitorados ( $1^{\circ}$ monitoramento)

Tabela 5.15 - Concentração de cátions na água subterrânea dos 15 poços monitorados ( $2^{\circ}$ monitoramento)

Tabela 5.16 - Resultados dos parâmetros físico-químicos analisados in situ

Tabela 5.17 - Variação da alcalinidade nos 15 poços monitorados durante 01 ano hidrológico 


\section{LISTA DE ANEXOS}

Anexo A - Dados geofísicos processados pelo programa RESIST ${ }^{\mathrm{TM}}$

Anexo B - Laudos laboratoriais das análises microbiológicas

Anexo C - Laudos laboratoriais das análises químicas

Anexo D - Anexo fotográfico 


\section{RESUMO}

Esta pesquisa teve: o objetivo de caracterizar a qualidade da água subterrânea influenciada por fossas sépticas e comuns no Bairro Recanto Mônica, Município de Itaquaquecetuba (SP), quanto aos aspectos químicos e microbiológicos.

Trata-se de um bairro onde residem aproximadamente 750 famílias de baixo poder aquisitivo, sem saneamento básico. A água subterrânea é captada pelos moradores através de poços rasos (cacimbas) e o esgoto sanitário gerado é disposto em fossas. A maioria das fossas cadastradas (95\%) é do tipo comum, sem critérios técnicos construtivos e com características sanitárias precárias. Deste total, cerca de $1 / 4$ são fossas negras, em contato direto com a água subterrânea local.

O bairro Recanto Mônica apresenta um relevo acidentado, com altitudes que variam de 700 a $800 \mathrm{~m}$ acima do nível do mar. O manto de intemperismo (solo) que recobre a área possui cerca de 10 a $15 \mathrm{~m}$ de espessura; a partir dessas profundidades, ocorre rocha alterada derivada de gnaisses graníticos (Complexo Embu, Grupo Açungui).

O aqüífero local é do tipo livre ou freático, constituido pelo material de alteração intempérica (solo e rocha alterada), cuja condutividade hidráulica calculada é da ordem de $10^{-4} \mathrm{~cm} / \mathrm{s}$. A velocidade média da água subterrânea local é de 25 m/ano, variando de 10,3 a 38,6 m/ano, em função de diferentes gradientes hidráulicos da área, associados à amplitude do relevo.

A qualidade da água subterrânea foi monitorada regularmente em 15 poços, utilizados para abastecimento doméstico (cacimbas), durante 01 ano hidrológico. A definição dos pontos de monitoramento foi em função do sentido de fluxo da água subterrânea e da localização das fossas existente (fontes de contaminação).

Foram monitorados poços de montante, de posição intermediária e de jusante em relação a 05 vertentes topográficas, onde existem diversas fossas instaladas. As amostras de água coletadas foram analisadas em campo e em laboratório. 
Em relação ao monitoramento microbiológico, foram detectadas elevadas concentrações de coliformes fecais e totais na água subterrânea (bactérias), além de colifagos (vírus indicativo de contaminação fecal) e Cryptosporidium (protozoário). Também foram detectados coliformes fecais e totais em elevadas concentrações em 02 córregos monitorados. Cryptosporidium foi detectado no material aquoso de 02 fossas analisadas, atestando que este protozoário provém do efluente das fossas e parasita o intestino humano. Não foi detectada a bactéria Salmonella nas amostras analisadas.

Em relação às análises químicas, o ion mais importante que foi detectado nas amostras de água subterrânea é o nitrato, por ser prejudicial à saúde, principalmente às crianças, quando ingerido acima de $10 \mathrm{mg} / \mathrm{L}$. Foram obtidas concentrações muito elevadas, até $604,94 \mathrm{mg} / \mathrm{L}$.

A sazonalidade (precipitação pluviométrica) e o posicionamento dos poços nas vertentes topográficas (influência de fossas) foram fatores que influenciaram a variação das concentrações das diversas substâncias dissolvidas na água subterrânea. Os aspectos sanitários e a densidade populacional do bairro Recanto Mônica, com características heterogêneas, também influenciaram as concentrações dos parâmetros monitorados.

A incidência de doenças relacionadas à ingestão de água contaminada na população do bairro, de acordo com dados do Posto de Saúde local, é maior no verão. A principal enfermidade é a diarréia causada por parasitas, que, quando não tratada, pode ocasionar complicações mais sérias, como a desidratação. Nos meses mais frios e menos chuvosos, ocorrem, principalmente, doenças respiratórias (bronquite e pneumonia).

Como medida de saúde preventiva, foi desenvolvido um programa informativo sobre métodos adequados de desinfecção da água para consumo junto à população do baịro Recanto Mônica, principalmente àquelas famílias que foram regularmente visitadas durante os trabalhos de campo para coleta de amostras de água. Também foi proferida uma palestra na escola pública do bairro, para crianças de diversas idades, onde foram discutidas questões sobre a pesquisa desenvolvida, métodos de saúde preventiva e higiene. 


\section{ABSTRACT}

The aim of this research was to investigate the influence of domestic septic system on the chemical and microbiological quality of groundwater in the Recanto Mônlca District, Itaquaquecetuba Town, São Paulo State.

The aproximately 750 lower class families who reside in the area do not have access to basic sanitation. The groundwater is exploited by the inhabitants through shallow wells (cacimbas) and the domestic sewage is discharged into septic system. Most of the recorded septic system are of the common type (95\%), i.e., whitout constructive criteria and showing precarious sanitary conditions. From this total amount, about $1 / 4$ are wet septic system, in direct contact with the local groundwater.

The relief in the Recanto Mônica District is rough, with altitudes ranging from 700 to $800 \mathrm{~m}$ above sea level. The weathering layer (soil), which covers the area, is about 10 to $15 \mathrm{~m}$ thick; beneath those depths there occurs the weathered rock originated from granitic gneisses (Embu Complex, Açungui Group).

The local aquifer, composed by the weathered material (soil and weathered rock), is a non-artesian one, whose calculated hydraulic conductivity is situated around $10^{-4} \mathrm{~cm} / \mathrm{s}$. The local groundwater medium velocity is $25 \mathrm{~m} / \mathrm{ano}$, ranging from 10,3 to $38,6 \mathrm{~m} / \mathrm{ano}$, as a function of different hydraulic gradients and relif amplitude in the area.

During one hydrologic year, the groundwater quality was monitored in 15 wells used for domestic water supply (cacimbas). The definition of the monitoring points has taken into account the direction of the groundwater flow and the location of the existing septic system (contamination sources).

The position of the controlled wells has been decided as a function of five topographic slopes where many septic system are installed, having been studied wells upgradient, in intermediate positions and downgradient. The water samples were analised in the field and in the laboratory.

The microbiologic monitoring has detected high fecal and total coliforms concentrations in the groundwater (bacteria), as well as colifags (an indication 
of fecal contamination) and Cryptosporidium (protozoan). High fecal and total coliforms concentrations have also been found in two creeks. Cryptosporidium has been detected in the aqueous material from two septic systems, attesting that this protozoa comes from the septic effluent and is a parasite in the human intestine. The bacteria Salmonella has not been found in the analysed samples.

Considering the chemical analyses, the most important ion detected in the groundwater samples was the nitrate, which can be harmful, mainly to children, when ingested above $10 \mathrm{mg} / \mathrm{L}$. Very high concentrations have been obtained, up to $604,94 \mathrm{mg} / \mathrm{L}$.

The sazonality (pluviometric precipitation) and the positioning of the wells in the topographic slopes (septic system influence) were the factors responsible for the concentration variation of the different substances dissolved in the groundwater. The sanitary aspects and the heterogeneous population density in the Recanto Mônica District also influenced the concentration of the monitored parameters.

According to data from the local Health Centre, the occurrence of contaminated water-related diseases in the district population is higher in the summer. The main disease is diarrhea caused by parasites, that can result in more serious complication if not properly treated, for example dehydration. During the colder and less rainy months the main diseases are respiratory ones (bronchitis and pneumonia).

As a measure of preventive medicine, an informative program has been developed with the inhabitants of the Recanto Mônica District, mainly those which had been regularly visited during the water sampling period, focusing on adequate methods of water disinfection for human consumption. A public lecture has also been carried out for children at the district school, when questions involving the present research, methods of preventive medicine and hygiene have been discussed. 


\section{INTRODUÇÃO}

Em 1984, no relatório do Senado Americano "Protegendo as Águas Subterrâneas", foram listadas mais de 30 fontes potenciais de contaminação divididas em 06 categorias principais. As fossas sépticas aparecem, entre outras, na Categoria 1, como fontes dimensionadas para descarregar substâncias (Fetter, 1993).

Nos Estados Unidos; relatórios de inventários estaduais mostraram que mais de metade dos estados consideram um conjunto de fontes como as mais poluidoras, entre as quais estão as fossas sépticas (Caicedo, 1996).

Aproximadamente 22 milhões de tanques sépticos são operados nos Estados Unidos e cerca de meio milhão de novos sistemas são instalados a cada ano. Estes sistemas atendem cerca de $30 \%$ da população americana (Fetter, op. cit.).

O relatório elaborado em conjunto por organizações internacionais, com destaque para a Organização Mundial da Saúde (OMS), calcula que 2,4 bilhões de pessoas não têm saneamento básico. Mais da metade desta população sem acesso a estes recursos vivem na Ásia e na África (ABES Informa, 2000).

Ainda segundo aquele relatório, as doenças que mais afetam a população sem água e esgoto são a diarréia, as verminoses e a cegueira por tracoma (conjuntivite contagiosa). Todo ano, 2,2 milhões de pessoas morrem de doenças diarréicas.

A situação em termos de sảneamento básico não é mais animadora na América latina, onde uma imensa população vive à margem das políticas sociais e, conseqüentemente, privada daqueles recursos necessários e indispensáveis à qualidade de vida do ser humano.

No que tange ao Brasil, para uma população superior a 161 milhões de pessoas, $47,50 \%$ estão conectados à rede de esgoto e $52,50 \%$ não estão. Destes, 37,32 \% têm sistemas de saneamento in situ e 15,18 \% não têm esgotamento sanitário (Cepis, 2000).

Ainda segundo o Centro Panamericano de Engenharia Sanitária (CEPIS, 2000), na cidade de São Paulo, para uma população superior a 16 milhões de 
pessoas, $88,95 \%$ têm ligação domiciliar e $11,05 \%$ não estão conectados à rede de esgoto. Destes, $7,76 \%$ usam fossas sépticas e 3,38 \% outros meios. Cremos que não estão computadas famílias que utilizam as fossas comuns, isto é, as fossas secas e as fossas negras, que são freqüentes não só nos bairros pobres da região Metropolitana de São Paulo, como em todas as periferias dos grandes centros urbanos brasileiros.

A contaminação das águas subterrâneas pelos sistemas de saneamento in situ - fossas sépticas, fossas secas e fossas negras, é um problema crônico nos países em desenvolvimento, com conseqüências muito sérias na saúde das populações.

No Brasil, a Associação Brasileira de Engenharia Sanitária (ABES), no cumprimento dos seus objetivos, entre os quais está a defesa intransigente da qualidade de vida da população brasileira, vem chamando de forma insistente a atenção das autoridades para a questão seríssima, que é a falta de uma política de saneamento ambiental adequado no país.

Acreditamos que a falta de saneamento básico no Brasil é o maior problema em termos sócio-ambientais. A maioria da população de baixa renda não tem coleta e tratamento de esgoto, sendo o mesmo disposto no local através de fossas ou lançados diretamente em córregos e rios.

Aquele quadro é responsável por problemas de saúde que afetam, principalmente, as crianças. Com efeito, onde não há esgotamento sanitário, em geral, também não existe água tratada e encanada. Como conseqüência, aquelas fossas contaminam o aqüífero freático, que é utilizado para abastecimento através de poços rasos, deficientemente construídos, cuja água subterrânea é utilizada nas atividades domésticas, inclusive para beber. As crianças são as grandes vítimas da ingestão de água de poço ou de rio contaminado por esgoto lançàdo in natura.

O trabalho efetuado em um bairro do município de Itaquaquecetuba, na Região Metropolitana de São Paulo, mostra uma situação precária em termos sanitários, ambientais e de saúde pública, comum no Brasil, naqueles lugares onde vive a população pobre. 


\subsection{Sistemas de saneamento in situ}

O esgoto doméstico municipal é usualmente coletado e destinado às Estações de Tratamento de Esgoto (ETE), onde este material é processado bioquimicamente, sob condições aeróbias. O efluente resultante, asséptico e com pequena carga orgânica, é então descartado no ambiente.

Os sistemas de saneamento in situ diferem do sistema convencional por tratar o esgoto doméstico no próprio local de sua produção. A fossa séptica é a principal representante desta técnica, muito utilizada em locais onde não existe rede coletora de esgotos, principalmente na zona rural e em áreas periféricas aos centros urbanos.

Como forma alternativa de tratar o esgoto doméstico sem comprometer a qualidade das águas subterrâneas, a eficiência das fossas sépticas está relacionada a características construtivas (características intrínsecas) e propriedades do terreno onde ela está instalada (características extrínsecas).

As características intrínsecas estão relacionadas ao projeto construtivo da fossa séptica, como compartimentos internos, entradas e saídas adequadas, compartimentos de inspeção e de saída de gases, além de suas dimensões em função do número de usuários.

As características extrínsecas estão relacionadas às propriedades hidrogeológicas do terreno onde está instalada, principalmente a permeabilidade do solo e seu posicionamento em relação à zona saturada do solo (lençol freático).

Além dessas características, a eficiência de tratamento do esgoto in situ depende da manutenção das fossas sépticas, executada periodicamente pelos próprios usuários ou por empresas especializadas nestes serviços. A manutenção das fossas sépticas deve ser feita, em média, a cada ano. Nesta operação, é removida a fração sólida acumulada neste período, a fim de evitar entupimentos e o baixo rendimento da digestão do esgoto.

Outro fator que pode comprometer a qualidade da água subterrânea de uma região onde existem sistemas de saneamento in situ, é a alta densidade de fossas sépticas por unidade de área. Em geral, quanto maior o número de fossas sépticas numa determinada região, maior será o risco de 
contaminação da água subterrânea local pelos efluentes gerados, podendo torná-la imprópria para o consumo humano sem prévio tratamento.

Em locais onde não há saneamento básico, muitas vezes as fossas sépticas são construídas de maneira inadequada, sem critérios técnicos, em posição indevida em relação à zona saturada do solo e com alta densidade de fossas por unidade de área. Nessas regiões, usualmente não há rede de distrlbulçăo de água tratada, sendo os poços rasos (caclmbas) a única opção de abastecimento de água da população. Neste caso, o risco à saúde humana é muito elevado, pois a água consumida pode conter microorganismos patogênicos e substâncias químicas tóxicas.

Dados do censo demográfico realizado pelo Instituto Brasileiro de Geografia e Estatística (IBGE, 1996, in SEADE 1997), mostram um aumento populacional das cidades periféricas às grandes metrópoles brasileiras, o que tem piorado as condições de vida da população que migrou para estas áreas.

Nos locais com ligações inadequadas de água e esgoto ou sem qualquer tipo de saneamento, a mortalidade infantil brasileira é de 78 por 1000, quase três vezes o observado em regiões onde há ligações adequadas (29 por 1000), - que revela uma estreita relação entre saneamento básico e saúde pública.

Segundo dados da Organização Mundial de Saúde (OMS) (Foster et al., 1987) a interação fossa-poço gera má qualidade de numerosos poços de abastecimento público e privado nos países menos desenvolvidos, sendo que, no Brasil, este binômio é responsável por cerca de $70 \%$ da taxa de mortalidade infantil.

\subsection{Aspectos construtivos e tipos de fossas sépticas}

Os projetos construtivos de fossas sépticas são normalizados pela Associação Brasileira de Normas Técnicas (ABNT), através da NBR 7.229 (ABNT 1982).

A Figura 1.1 mostra o posicionamento de uma fossa séptica no terreno, que recebe e processa o esgoto doméstico, eliminando o efluente por infiltração no solo. Na Figura 1.2 é apresentado um detalhe da caixa séptica, local onde o esgoto doméstico é processado (Batalha, 1989). 


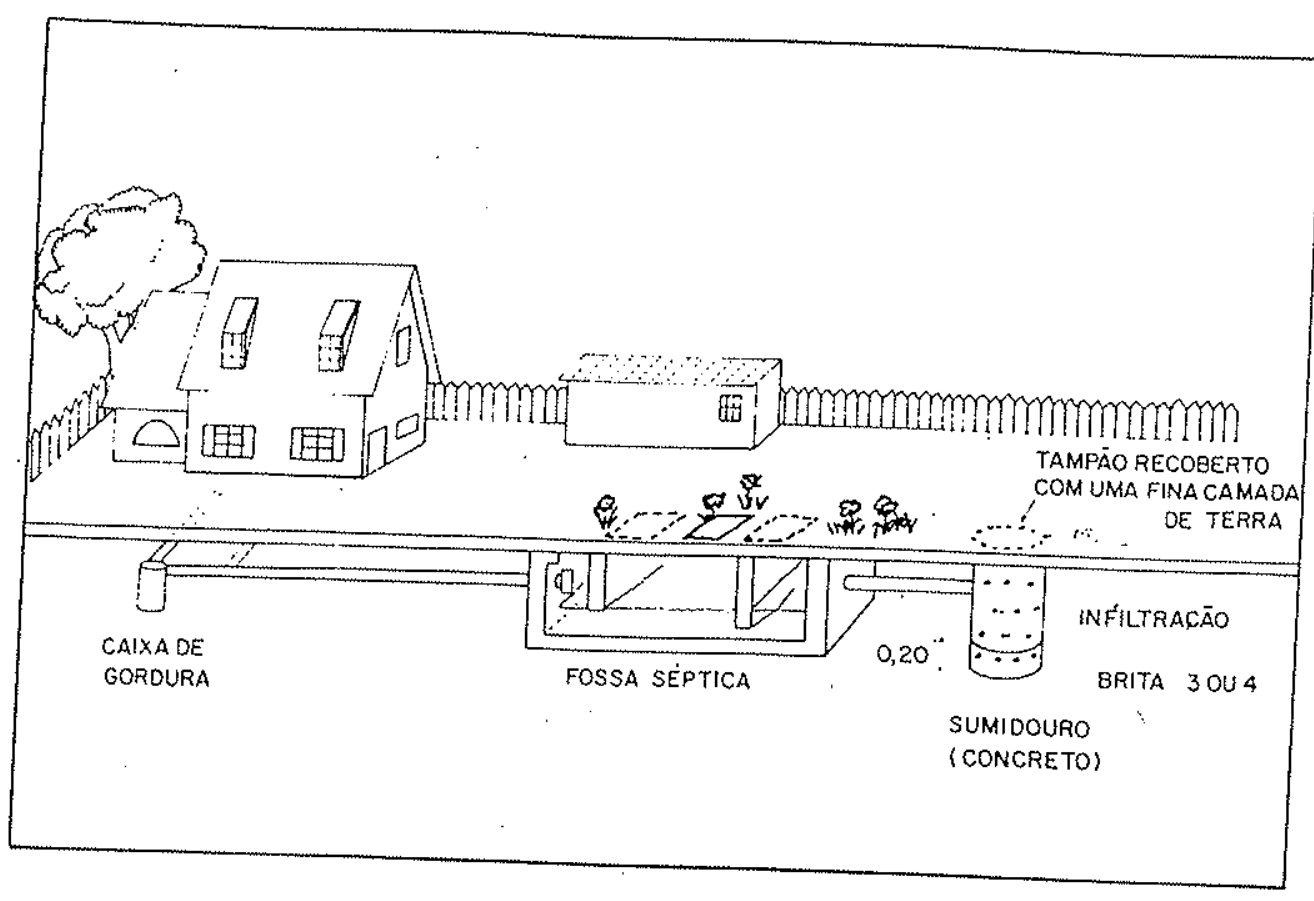

Figura 1.1 - Visualização de um sistema de saneamento în situ (extraído de Batalha, 1989)

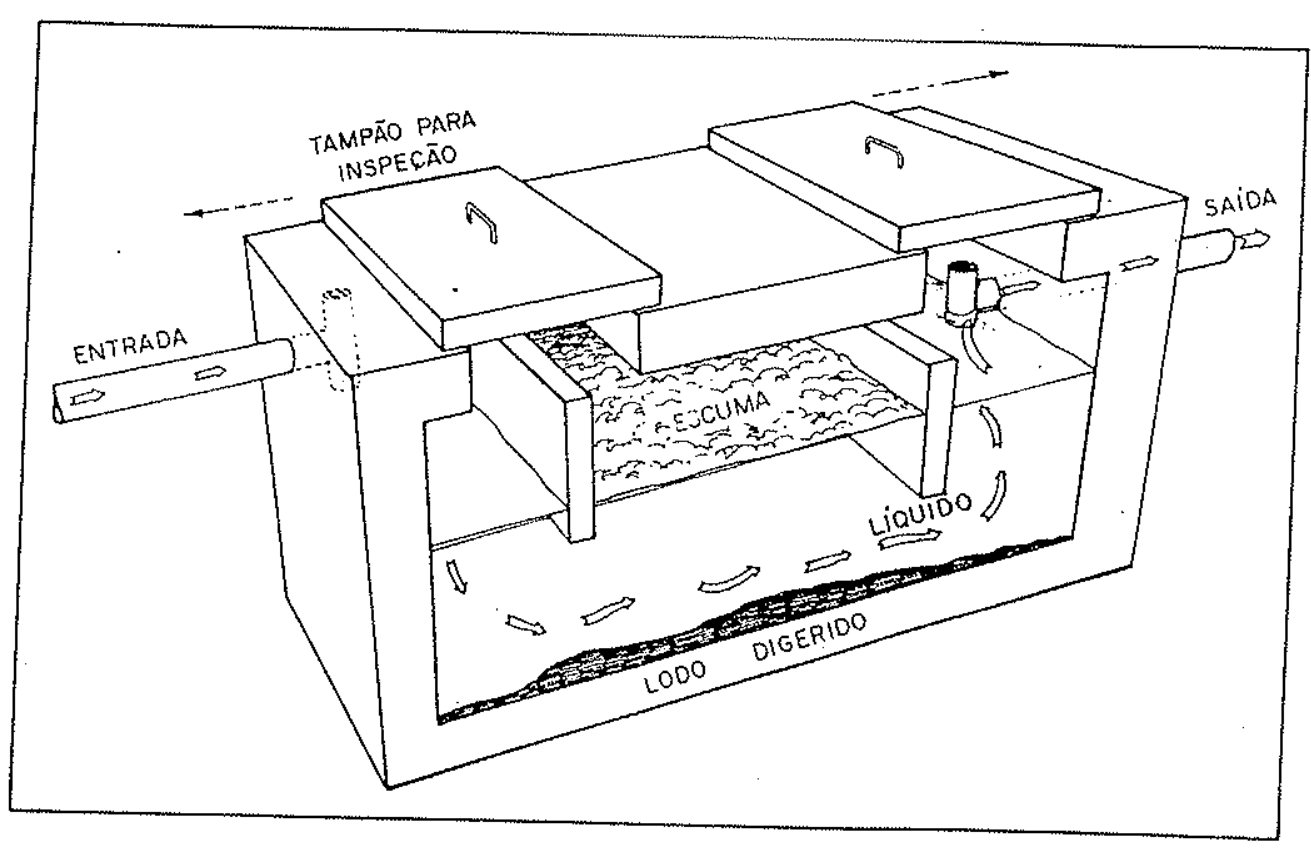

Figura 1.2 - Detalhe da fossa séptica, onde o esgoto é processado (extraído de Batalha, 1989) 
As Tabelas 1.1 e $\mathbf{1 . 2}$ mostram, respectivamente a eficiência de remoção de determinados compostos químicos e as dimensões das fossas em função do número de usuários (Batalha, op. cit.).

Em função das características intrínsecas e extrínsecas relacionadas às fossas sépticas, discutidas no item anterior, foram dadas denominações distintas às modalidades dos sistemas de saneamento in situ, que são:

(a) Fossa séptica: construção sanitária de acordo com as normas da ABNT e com projeto técnico executado por profissional ou empresa habilitados;

(b) Fossa comum: construção sanitária que não apresenta conformidade com as normas da ABNT, construída sem projeto técnico de engenharia. Se estiver posicionada na zona não saturada do solo é denominada fossa seca; posicionada na zona saturada do solo é denominada fossa negra. A Figura $\mathbf{1 . 3}$ representa de maneira esquemática estas duas modalidades de fossas comuns.

\subsection{Aspectos geoquímicos relacionados aos sistemas de saneamento in situ}

\subsubsection{O ciclo do nitrogênio}

O nitrogênio é o elemento químico mais importante a ser avaliado em estudos de contaminação das águas pelo esgoto doméstico em função dos seguintes aspectos:

(a) Elevada concentração relativa no esgoto e nos efluentes derivados das fossas sépticas;

(b) Diversidade de espécies químicas em que pode estar presente;

(c) Susceptibilidade geoquímica em função de variações das características ambientais. 
Tabela 1.1 - Estimativa da eficiência de uma fossa séptica (Batalha, 1989)

\begin{tabular}{|c|c|c|}
\hline Parâmetro & $\begin{array}{c}\text { Valor em mg/L no efluente } \\
\text { da fossa séptica }\end{array}$ & \% da Remoção \\
\hline Alcalinidade & 390 & 225 \\
\hline Carbono orgânico total & 129 & 46 \\
\hline Cloretos & 95 & 111 \\
\hline DBO & 160 & 27 \\
\hline DQO & 323 & 47 \\
\hline Fosfatos & 34 & 240 \\
\hline Fósforo total & 18 & 40 \\
\hline Nitrogênio amoniacal & 27 & 8 \\
\hline Nitrogênio total & 32 & 8 \\
\hline Sólidos em suspensão & 90 & 70 \\
\hline Sólidos totais & 378 & 46 \\
\hline Surfactantes & 7,6 & 67 \\
\hline
\end{tabular}


Tabela 1.2 - Dimensões de fossas sépticas (Batalha, 1989)

\begin{tabular}{|c|c|c|c|c|}
\hline \multicolumn{5}{|c|}{ Dimensões internas } \\
\hline Número de pessoas & Comprimento $(\mathrm{m})$ & Largura $(\mathrm{m})$ & Altura $(\mathrm{m})$ & Cäpacidade $(\mathrm{L})$ \\
\hline até 7 & 1,60 & 0,80 & & 1535 \\
\hline 9 & 1,80 & 0,90 & & 1945 \\
\hline 12 & 2,10 & 1,05 & 1,50 & 2645 \\
\hline 15 & 2,35 & 1,15 & & 3240 \\
\hline 20 & 3,00 & 1,20 & & 4320 \\
\hline
\end{tabular}




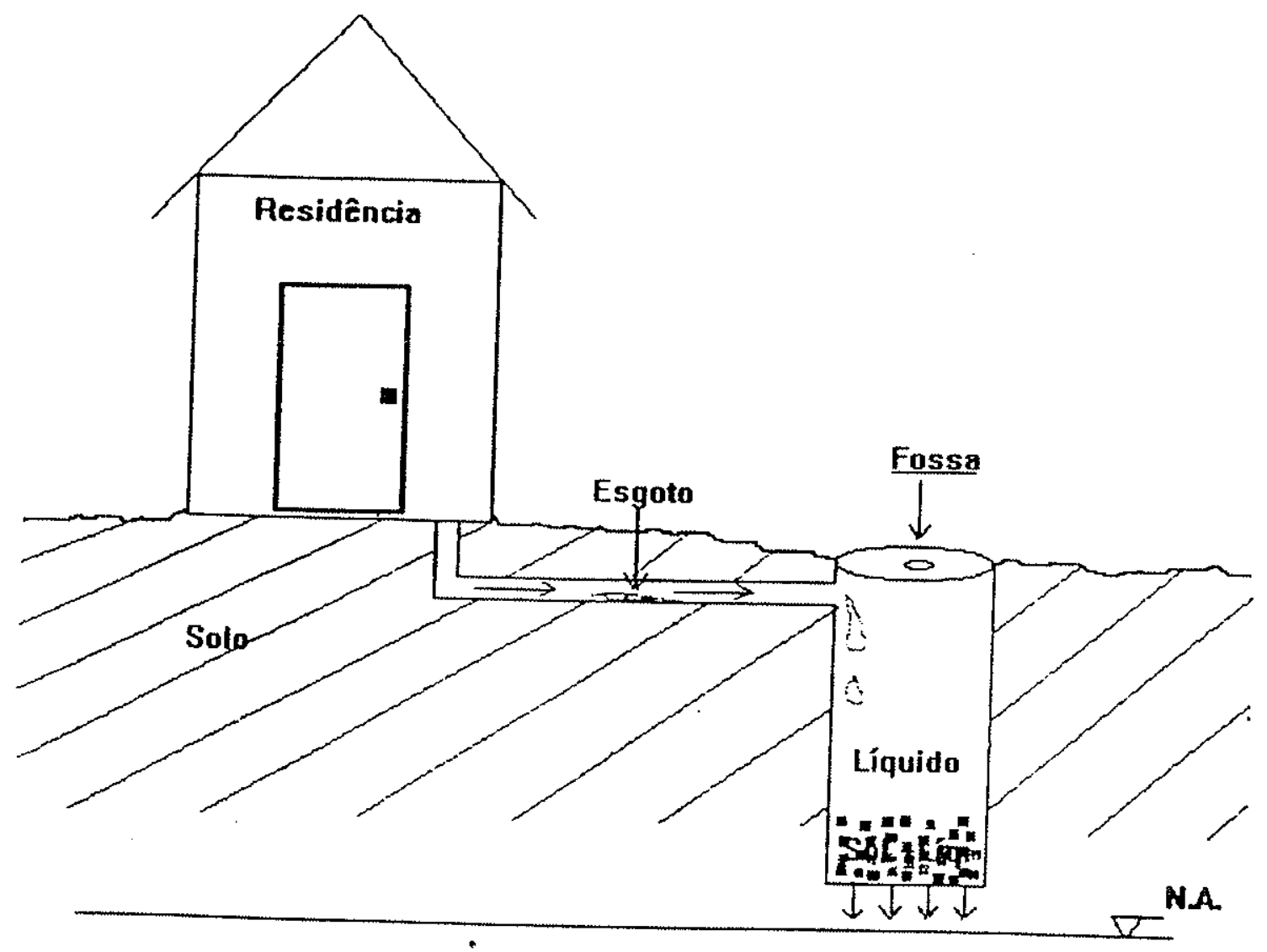

(a)

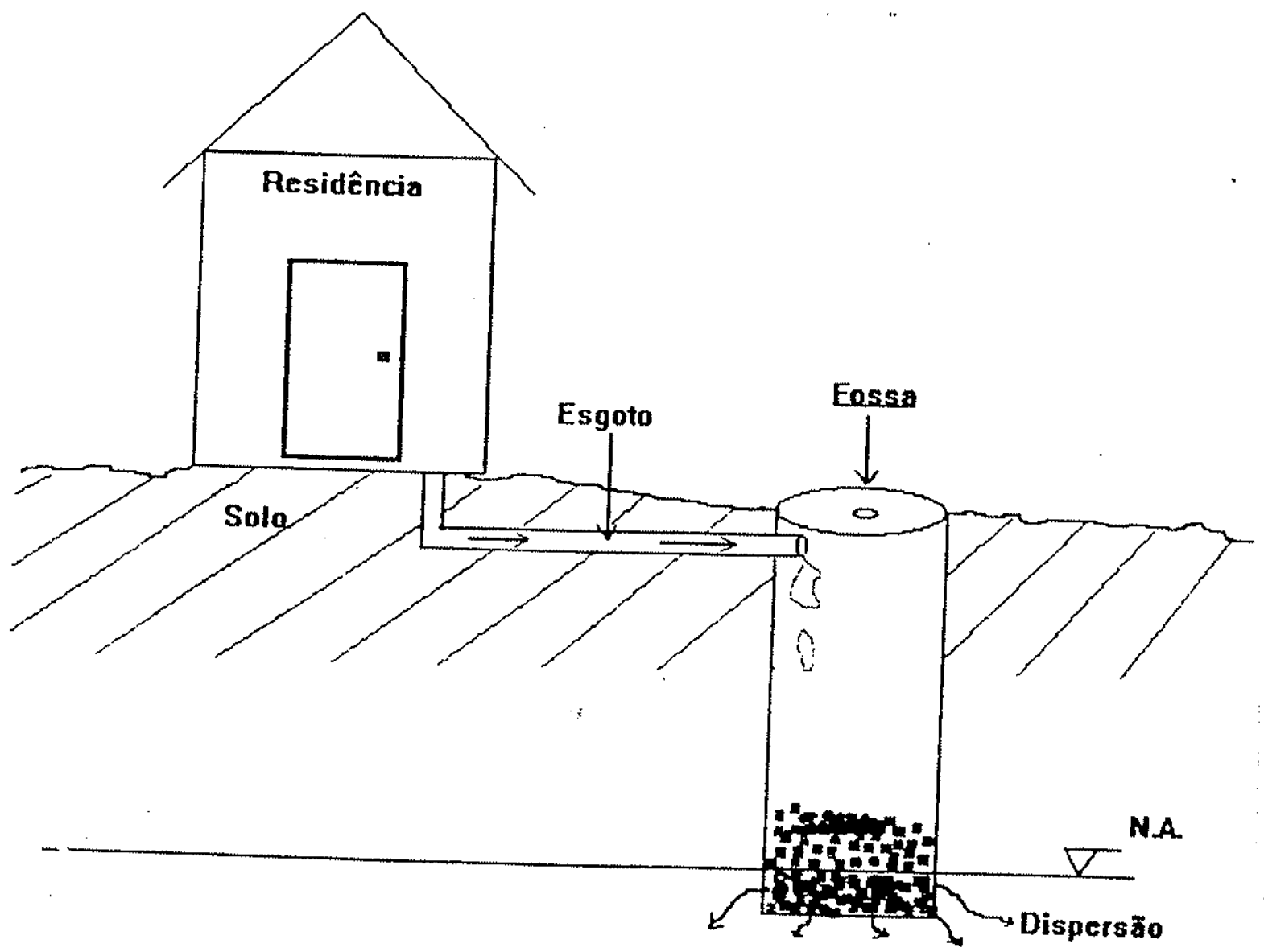

(b)

Figura 1.3 - Fossa seca (a) e fossa negra (b) 
O reservatório natural de nitrogênio do planeta é a atmosfera, na forma

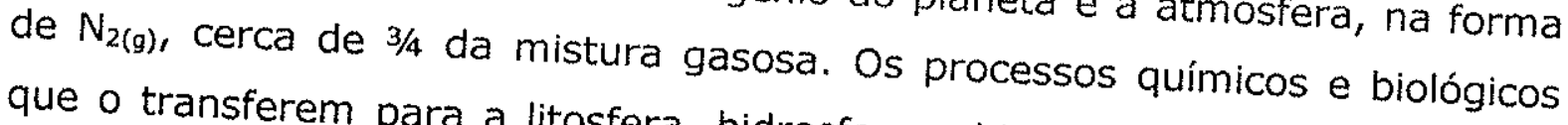

O elemento nitrogênio é encontrado na natureza em compostos químicos cujas valências variam de $+05\left(\mathrm{NO}_{3}{ }^{-}\right)$até $-03\left(\mathrm{NH}_{4}{ }^{+}\right)$(Appelo \& Postma,
1993):

$$
\mathrm{NO}_{3}^{-} \rightarrow \mathrm{NO}_{2}^{-} \rightarrow \mathrm{N}_{2(g)} \rightarrow \mathrm{NH}_{4}^{+} \quad \text { (série de redução) }
$$

As concentrações naturais das espécies nitrogenadas nas águas subterrâneas e superficiais são baixas. Entretanto, devido à influência antrópica no meio físico, estas concentrações podem ser localmente ou regionalmente elevadas.

A indução de compostos nitrogenados nas águas subterrâneas e superficiais ocorre da seguinte forma:

(a) Indução natural (Hem, 1985). A fixação do nitrogênio pode ocorrer pela oxidação do $\mathrm{N}_{2(\mathrm{~g})}$ devido a descargas elétricas (relâmpagos) produzindo $\mathrm{NO}_{2}{ }^{-}$e $\mathrm{NO}_{3}{ }^{-}$. Outra forma é a fixação biológica realizada principalmente por algas azuis e verdes, além de bactérias que vivem em simbiose nas raízes de determinadas plantas (leguminosas);

(b) Indução antrópica: As principais fontes de compostos químicos nitrogenados são os fertilizantes, efluentes de fossas sépticas, esgoto municipal não tratado, efluentes industriais nitrogenados e a fração orgânica dos resíduos sólidos urbanos depositados em aterros sanitários e lixões (Domenico \& Schwartz, 1990; Alloway \& Ayres, 1997; Bowen, 1986).

Dentre as espécies químicas nitrogenadas, o nitrato $\left(\mathrm{NO}_{3}{ }^{-}\right)$é o composto mais investigado por ser prejudicial à saúde humana quando ingerido em determinadas quantidades. Cabe referir que o nitrito também é prejudicial à saúde humana, porém este composto é muito instável no ambiente, oxidandose rapidamente a nitrato. De acordo com a Portaria $n^{\circ} 1.469$ do Ministério da Saúde de 29.12.2000, a concentração máxima permitida de nitrato na água 
potável é de $10 \mathrm{mg} / \mathrm{L}$. Acima desta concentração, o nitrato pode causar metahemoglobinemia principalmente em crianças. Após ser ingerido, o nitrato é convertido em nitrito $\left(\mathrm{NO}_{2}{ }^{-}\right)$, o qual oxida o ferro ferroso $\left(\mathrm{Fe}^{2+}\right)$ das moléculas de hemoglobina em ferro férrico $\left(\mathrm{Fe}^{3+}\right)$, tornando o sangue incapaz de fixar oxigênio, causando anoxia e, em casos agudos, a morte.

Há 02 reações químicas principais que controlam a concentração de nitrato no ambiente aquoso e que são catalisadas por microorganismos (Freeze \& Cherry, 1979):

(a) Desnitrificação, onde $\mathrm{O} \mathrm{NO}_{3}{ }^{-}$é reduzido a $\mathrm{N}_{2(g)}$. $\mathrm{O}$ nitrato pode se reduzir a $\mathrm{NH}_{4}{ }^{+}$, porém em proporções restritas;

(b) Nitrificação, onde as aminas da matéria orgânica (esgoto, por exemplo) são oxidadas em nitrito e nitrato.

A estabilidade dos compostos nitrogenados em meio aquoso pode ser representada em diagramas de óxido-redução, em função do $\mathbf{p H}$ e Eh da água. A Figura 1.4 mostra um diagrama de óxido-redução (Apello \& Postma, 1993) com as principais espécies nitrogenadas.

A partir das condições de estabilidade geoquímica das principais espécies encontradas na água subterrânea, pode-se hierarquizar as reações que ocorrem em ambientes extremamente redutores até em ambientes extremamente oxidantes. A Figura 1.5 representa esta seqüência, incluindo a reação de desnitrificação, a redução do nitrato, a oxidação do amônio e oxidação do nitrogênio gasoso.

É possivel estabelecer um zoneamento vertical de estabilidade de algumas espécies químicas encontradas na água subterrânea em função da profundidade (Appelo \& Postma, 1993). Espécies químicas na forma oxidada $\left(\mathrm{O}_{2}, \mathrm{NO}_{3}{ }^{-}\right.$e $\left.\mathrm{SO}_{4}{ }^{2-}\right)$ ocorrem nas porções mais rasas do aqüífero, enquanto que compostos sob a forma reduzida $\left(\mathrm{Mn}^{2+}, \mathrm{Fe}^{2+}, \mathrm{H}_{2} \mathrm{~S}\right.$ e $\left.\mathrm{CH}_{4}\right)$ ocorrem em profundidades maiores, como mostrado esquematicamente na Figura 1.6. 


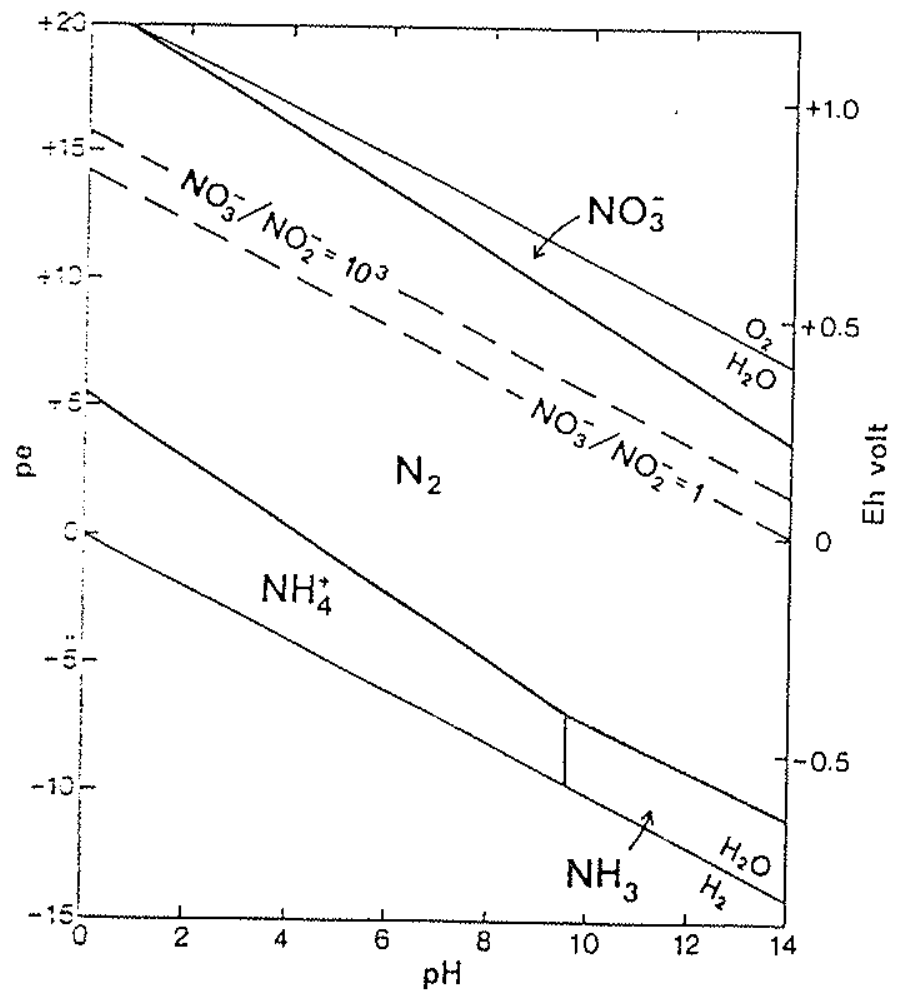

Figura 1.4 - Diagrama de óxido-redução das espécies químicas da série nitrogenada

(válido para condições dePN $\mathrm{N}_{2}=0,70 \mathrm{~atm}$ a $20^{\circ} \mathrm{C}$ )

(extraído de Appelo \& Postma, 1993) 


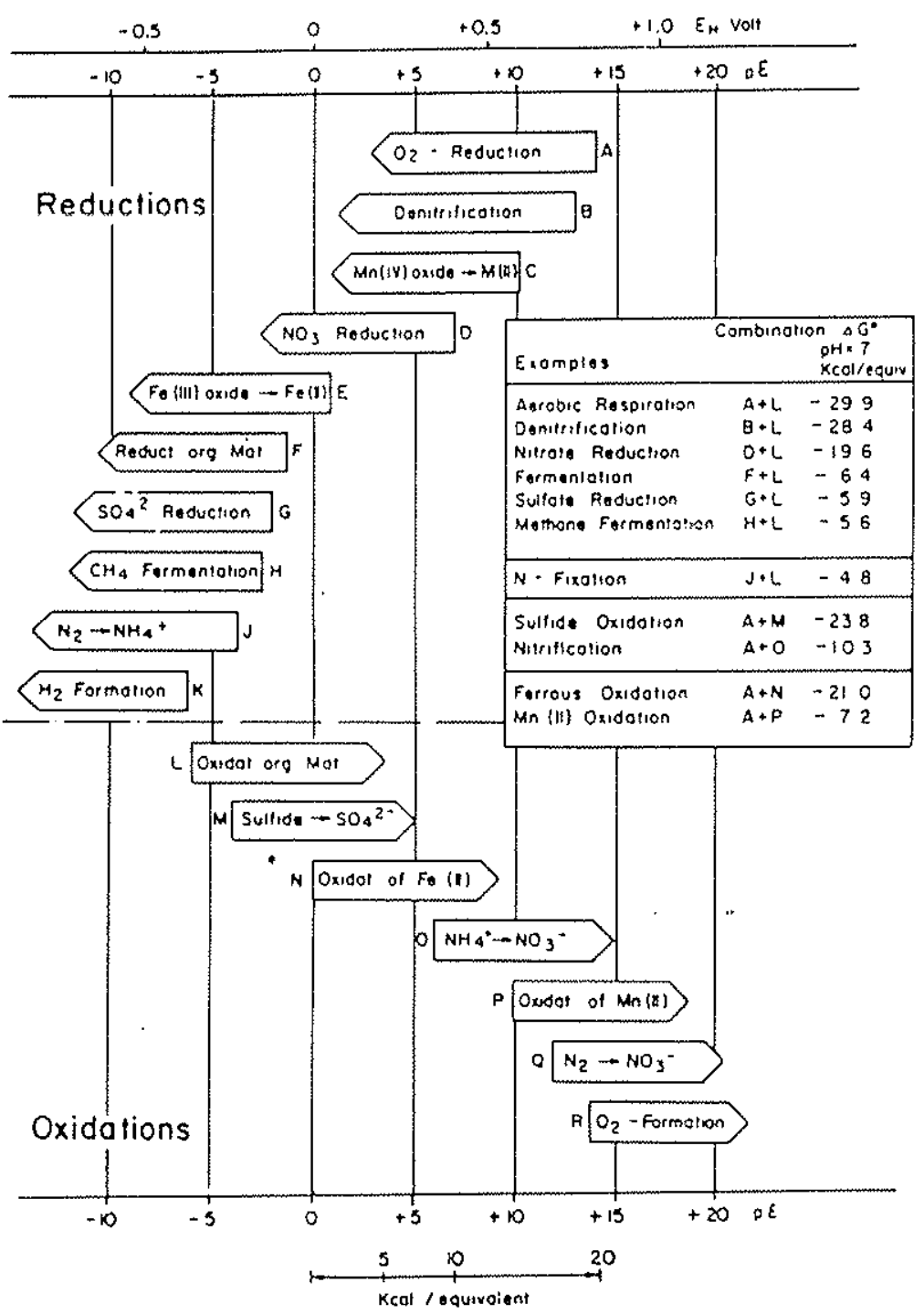

Figure 7.9. Sequences of important redox processes at $\mathrm{pH} 7$ in natural systems (Stumm and Morgan, 1981, reproduced with permission of John Wiley \& Sons, copyright 1981).

Figura 1.5 - Seqüência de importantes processos de óxidoredução $(\mathrm{pH} \mathrm{7}) \mathrm{em}$ sistemas naturais

(extraído de Stumm \& Morgan, 1981) 

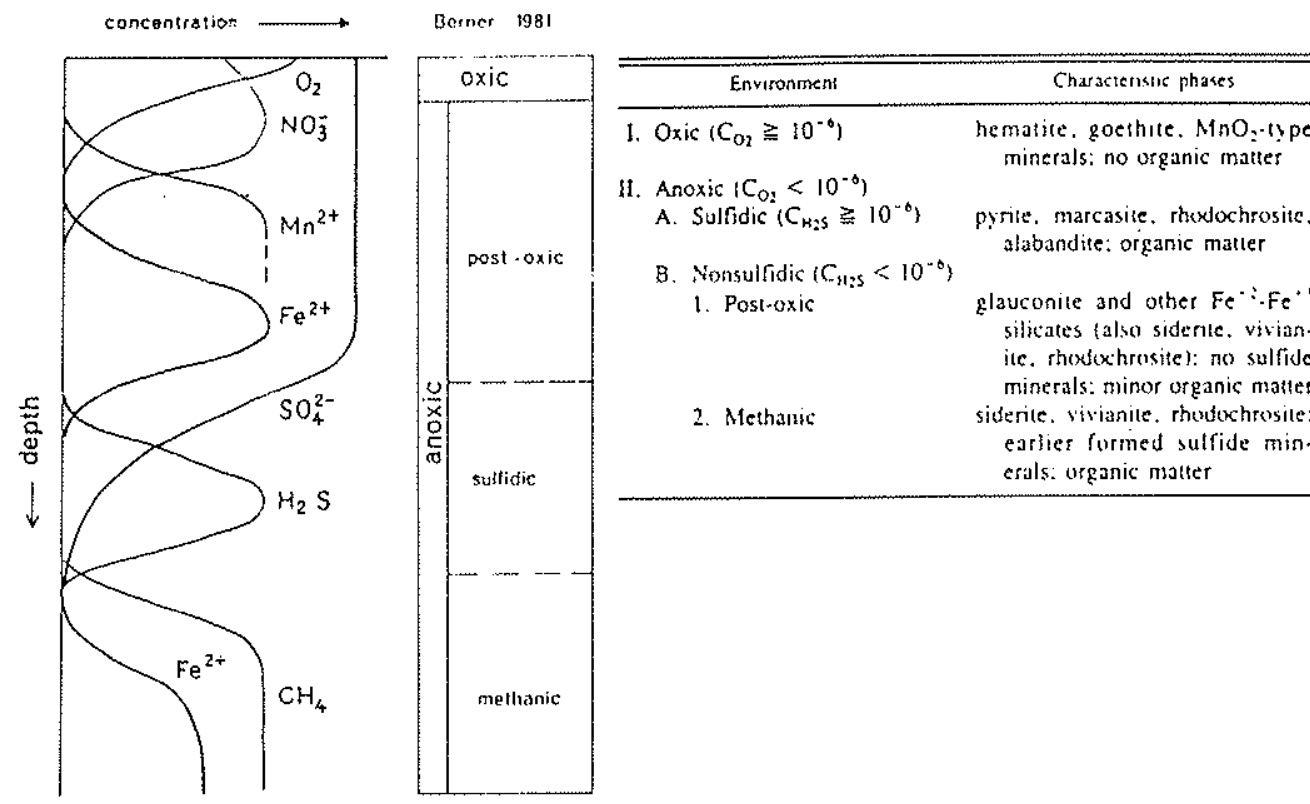

11. Anoxic $\left(\mathrm{C}_{02}<10^{-6}\right)$

A. Sulfidic $\left(C_{k, S} \geq 10^{-6}\right)$ pysite, marcasite, rhexdochrosite.

B. Fonsulfidic $\left(\mathrm{C}_{9135}<10^{-0}\right)$

1. Post-oxic alabandite: organic matter

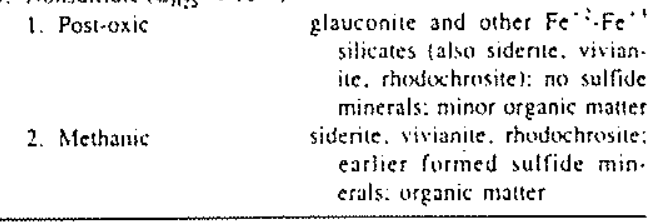

Figura 1.6 - Composição da água subterrânea como reflexo da seqüência de processos redutores

(extraído de Appelo \& Postma, 1993) 


\subsubsection{Modelo geoquímico conceitual relacionado às fossas sépticas}

No campo da Hidrogeologia, tanto no Brasil como no exterior, existem relativamente poucos estudos sobre os impactos causados pelos efluentes de fossas sépticas nas águas subterrâneas. As fossas sépticas são pesquisadas mais freqüentemente na árẻa da Engenharia Sanitária, porém em estudos relacionados aos aspectos construtivos e operacionais desses sistemas. Alguns estudos relacionados à hidrogeologia urbana incluem as fossas sépticas como fontes de contaminação química e microbiológica (Ferreira, 1999; Cavalcanti, 1996; Castro, 1994; Melo, 1998).

Um dos estudos mais completos sobre os impactos de fossas sépticas no sistema hídrico subterrâneo, que discute os aspectos geoquímicos das fossas sépticas, é de autorla de Wilhelm et al. (1994). Segundo estes autores, há 02 regiões geoquimicamente distintas relacionadas às fossas sépticas:

(a) Tanque séptico - principal compartimento da fossa séptica, no qual ocorrem reações bioquímicas anaeróbias devido à escassez de $\mathrm{O}_{2}$ livre (ambiente redutor). É a região onde ocorrem as principais reações de decomposição da matéria orgânica e de seus subprodutos;

(b) Dreno de efluentes - é o compartimento de saída da fossa séptica, onde ocorre a infiltração do efluente sanitário na zona não saturada do solo. Como nesta região há $\mathrm{O}_{2}$ disponível, ocorrem reações bioquímicas aeróbias (ambiente oxidante).

A Figura 1.7 mostra (a) uma representação esquemática de fossa séptica posicionada corretamente no solo (aqüífero freático) e (b) as principais reações químicas que ocorrem nas duas regiões definidas.

Wilhelm et al. (1994) consideram a água subterrânea (zona saturada) uma segunda zona anaeróbia, pois, ao contrário da zona não saturada do solo, apresenta pouco $\mathrm{O}_{2}$ dissolvido. Ao atingir a zona saturada pela ação gravitacional (fluxo descendente), o efluente sanitário sofre novas reações anaeróbias. A reação química principal nesta região é a desnitrificação, onde o nitrato previamente gerado é transformado em nitrogênio gasoso, podendo ser eliminado do sistema hídrico subterrâneo. 


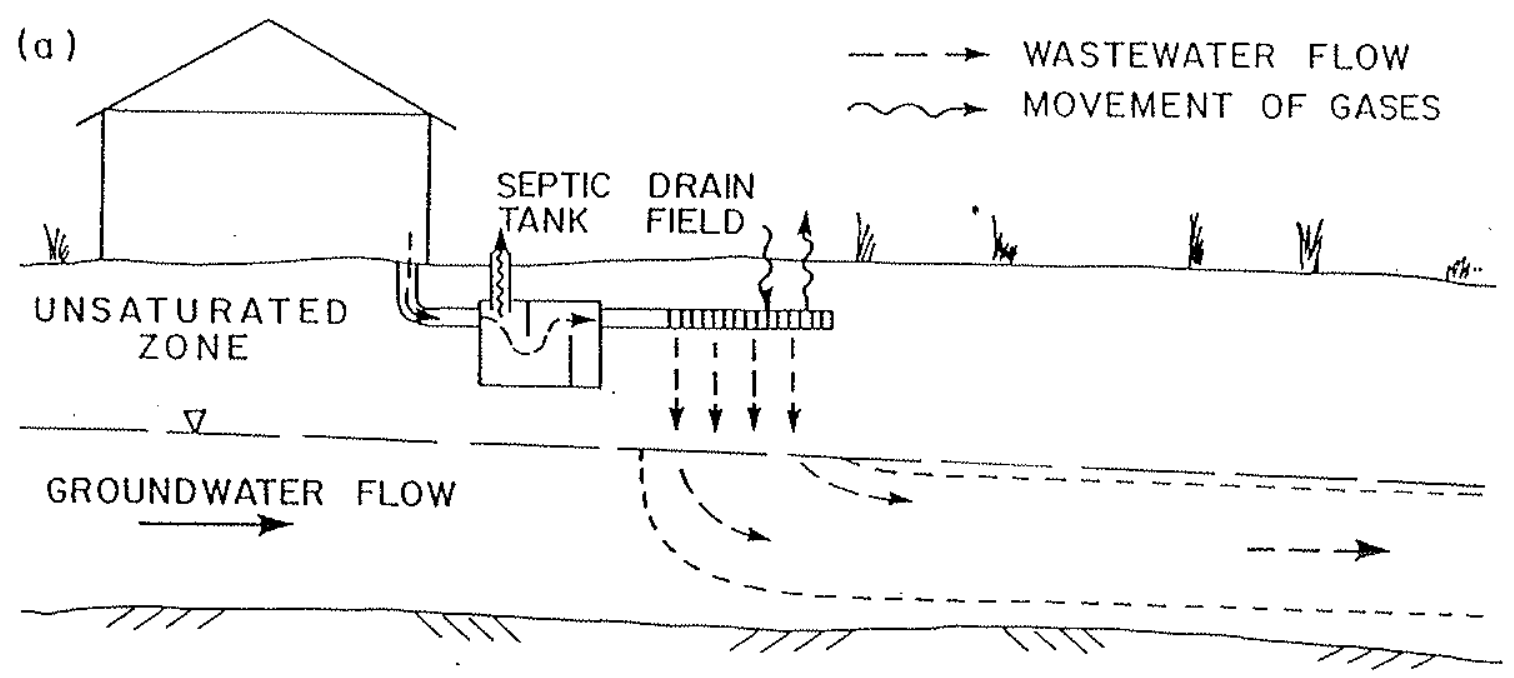

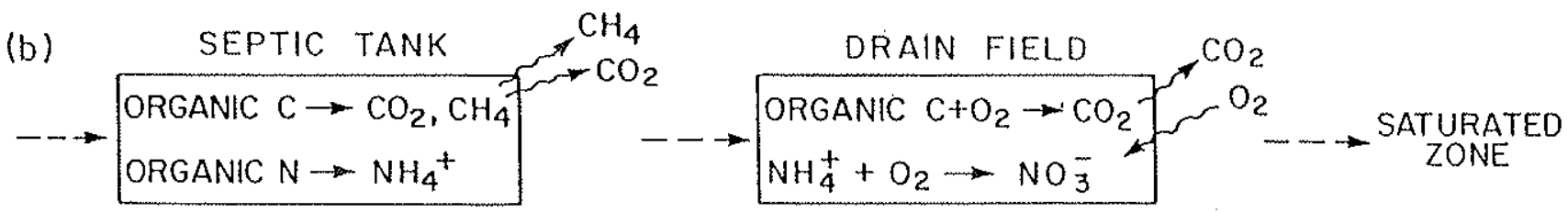

Figura 1.7 - Esquema genérico de uma fossa séptica

(a) Seção esquemática de uma fossa séptica, incluindo o tanque séptico, o dreno de efluentes e a pluma de solutos dissolvidos na água subterrânea;

(b) Seqüência simplificada das reações de óxido-redução que ocorrem no tanque séptico e no dreno de efluentes 
As principais reaç̃̃es químicas que ocorrem nas três regiões descritas estão sumariadas na Tabela 1.3. Cabe salientar que estas reações são catalisadas por microorganismos presentes naturalmente no solo. Os microorganismos patogênicos, eventualmente presentes nos efluentes de fossas sépticas, serão discutidos no item 1.4.

$\mathrm{Na}$ área estudada, o número de fossas, principalmente do tipo comum, é elevado, cerca de 750 fossas se contabilizarmos que há 01 fossa para cada residência no bairro. Neste caso as fossas existentes podem ser classificadas como fontes de contaminação difusas, por estarem disseminadas por todo bairro.

A Figura 1.8 representa esquematicamente o modelo conceitual do mecanismo de contaminação da água subterrânea, incluindo os diferentes sistemas de saneamento existentes na área (fossas sépticas e comuns), instalados num aqüífero freático ao longo de uma vertente topográfica. Assumiu-se que a amplitude de contaminação da água subterrânea é limitada e própria para cada vertente topográfica, com grau de contaminação progressivo de montante para jusante. A magnitude da contaminação é função da densidade de fossas ao longo das vertentes e das características sanitárias relacionadas às mesmas (aspectos construtivos e operacionais).

\subsection{Aspectos microbiológicos relacionados ao esgoto doméstico}

A Microbiologia é o ramo da Biologia que estuda os organismos microscópicos quanto à taxonomia, morfologia, reprodução, fisiologia, e sua interação com outros organismos e o ambiente.

A Microbiologia Ambiental estuda os microorganismos presentes nos diversos elementos do ambiente - solo, água e ar. Tradicionalmente, estes estudos são realizados em laboratório, em meios de cultura e condições ambientais controlados (acidez, oxigenação, temperatura, luminosidade, etc.). Tais condições são denominadas microcosmos, os quais visam reproduzir as condições ambientais reais. 
Tabela 1.3: Principais reações biogeoquímicas relacionadas aos sistemas sépticos subterrâneos (baseado em Wilhelm et al., 1994)

\begin{tabular}{|c|c|c|}
\hline Tanque séptico - ambiente anaerobio & Zona náo saturada - ambiente aeróbio & Zona saturada-ambiente anaeróbio \\
\hline $\begin{array}{c}\text { Hidrólise das molécula orgânicas: } \\
\text { proteínas }+\mathrm{H}_{2} \mathrm{O} \rightarrow \text { aminoácidos } \\
\text { carboidratos }+\mathrm{H}_{2} \mathrm{O} \rightarrow \text { açúcares simples } \\
\text { gorduras }+\mathrm{H}_{2} \mathrm{O} \rightarrow \text { ácido graxo }+ \text { glicerol } \\
\text { Liberação do amônio: } \\
{\left[\mathrm{CO}\left(\mathrm{NH}_{3}^{+}\right)_{2}\right]^{*}+\mathrm{H}_{2} \mathrm{O} \rightarrow 2 \mathrm{NH}_{4}^{+}+\mathrm{CO}_{2}} \\
\text { aminoácidos }+\mathrm{H}_{2} \mathrm{O} \rightarrow \mathrm{NH}_{4}^{+}+\text {compostos orgânicos } \\
\text { Fermentação: } \\
\text { aminoácidos, açúrares } \rightarrow \mathrm{H}_{2}, \mathrm{CH}_{3} \mathrm{OO} * * \text { ácidos orgânicos } \\
\text { Oxidação anaeróbia: } \\
\text { Ácido graxo }+\mathrm{H}_{2} \mathrm{O} \rightarrow \mathrm{H}_{2}, \mathrm{CH}_{3} \mathrm{OO} \\
\text { Redução do sulfato: } \\
\mathrm{SO}_{4}^{2-}+2 \mathrm{CH}_{2} \mathrm{O}^{* * *}+2 \mathrm{H}^{+} \rightarrow \mathrm{H}_{2} \mathrm{~S}+2 \mathrm{CO}_{2}+2 \mathrm{H}_{2} \mathrm{O} \\
\text { Metanogênese: } \\
\mathrm{CH}_{3} \mathrm{OO}^{-}+\mathrm{H}^{+} \rightarrow \mathrm{CH}_{4}+\mathrm{CO}_{2} \\
\mathrm{CO}_{2}+4 \mathrm{H}_{2} \rightarrow \mathrm{CH}_{4}+2 \mathrm{H}_{2} \mathrm{O}\end{array}$ & $\begin{array}{l}\text { Oxidação da matéria orgânica: } \\
\qquad \begin{array}{c}\mathrm{CH}_{2} \mathrm{O}+\mathrm{O}_{2} \rightarrow \mathrm{CO}_{2}+\mathrm{H}_{2} \mathrm{O} \\
\text { Nitrificação: } \\
\mathrm{NH}_{4}^{+}+2 \mathrm{O}_{2} \rightarrow \mathrm{NO}_{3}^{-}+2 \mathrm{H}^{+}+\mathrm{H}_{2} \mathrm{O} \\
\text { Oxidação do sulfeto: } \\
\mathrm{H}_{2} \mathrm{~S}+2 \mathrm{O}_{2} \rightarrow \mathrm{SO}_{4}^{2-}+2 \mathrm{H}^{+} \\
\text {Solução tampão do carbonato: } \\
\mathrm{H}^{+}+\mathrm{HCO}_{3} \rightarrow \mathrm{H}_{2} \mathrm{CO}_{3} \\
\mathrm{CaCO}_{3}+\mathrm{H}^{+} \rightarrow \mathrm{Ca}^{2+}+\mathrm{HCO}_{3} \\
\mathrm{CaCO}_{3}+\mathrm{CO}_{2}+\mathrm{H}_{2} \mathrm{O} \rightarrow \mathrm{Ca}^{2+}+\mathrm{HCO}_{3}\end{array}\end{array}$ & $\begin{array}{c}\text { Desnitrificação: } \\
4 \mathrm{NO}_{3} \cdot 5 \mathrm{CH}_{2} \mathrm{O}+4 \mathrm{H}^{+} \rightarrow 2 \mathrm{~N}_{2}+5 \mathrm{CO}_{2}+7 \mathrm{H}_{2} \mathrm{O}\end{array}$ \\
\hline
\end{tabular}

$\times\left[\mathrm{CO}\left(\mathrm{NH}_{3}^{+}\right)_{2}\right]=$ uréia

$* * \mathrm{CH}_{3} \mathrm{OO}^{*}=$ ácido acético

$* * * \mathrm{CH}_{2} \mathrm{O}=$ matéria orgânica 


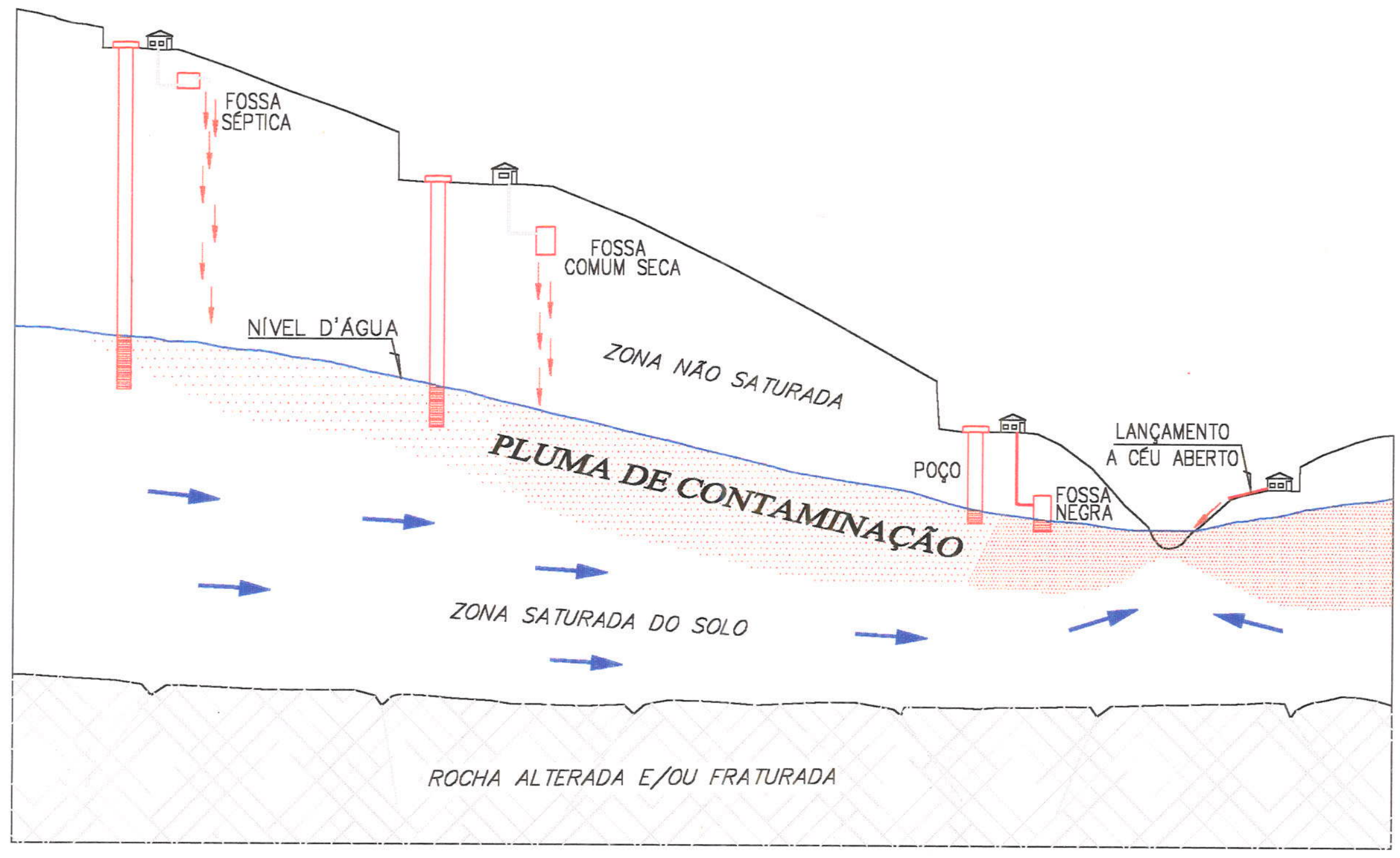

Figura 1.8 - MODELO CONCEITUAL DA CONTAMINAÇÃO DA ÁGUA SUBTERRÂNEA PELO ESGOTO SANITÁRIO DOMÉSTICO 
Nos últimos anos, vários estudos estão sendo realizados in $10 c 0$, sob condições reais. Em estudos de contaminação do solo e da água, a Microbiologia tem sido útil para esclarecer a degradação de diversos compostos, orgânicos e inorgânicos, contribuindo para o aprimoramento de técnicas de remediação de áreas contaminadas. Por outro lado, no campo da saúde pública, métodos eficazes e mais baratos de detecção dos agentes patogênicos, causadores de doenças aos seres humanos, têm sido desenvolvidos.

A água é um importante meio de transmissão de doenças, que podem ser de dois tipos (Sanchez, 1997):

(a) Doenças de transmissão hídrica: a água atua como veículo do agente etiológico, proveniente de excretas de pessoas ou animais infectados;

(b) Doenças de origem hídrica: causadas por substâncias químicas presentes na água em concentrações inadequadas para o consumo humano, de origem natural ou antrópica (metahemoglobinemia, por exemplo, causada.por nitrato).

\subsubsection{Doenças causadas por bactérias}

Dos microorganismos existentes, as bactérias apresentam o maior número de espécies conhecidas e, sem dúvida, é o grupo de organismos mais importante para a manutenção da vida em nosso planeta (Sanchez, 1997).

Por outro lado, são as principais causadoras das doenças de veiculação hídrica de diversas fontes, pois apresentam formas variadas e aptas a ambientes variados e extremos.

Pertencem ao Reino Monera e, morfologicamente, são organismos procariontes, não possuindo núcleo organizado. Seu tamanho varia de 0,3 a $10 \mu \mathrm{m}(1 \mu \mathrm{m}=1 / 1000 \mathrm{~mm})$. A Tabela 1.4 mostra as principais características morfológicas das bactérias.

As bactérias possuem variadas estruturas, sendo que as principais são mostradas na Tabela 1.5. 
Tabela 1.4: Características morfológicas das bactérias

\begin{tabular}{|c|c|c|}
\hline Forma & Variedades & Especificaçóes / Exemplos \\
\hline \multirow{3}{*}{ Cocos } & Diplococos & agrupados em pares \\
\hline & Estafilococos & agrupados em cachos \\
\hline & Estreptococos & agrupados em cadeias \\
\hline \multirow[b]{2}{*}{ Bacilos } & Extremidade reta & \\
\hline & Extremidade curva & $\begin{array}{l}\text { bacilo da tuberculose; bactérias } \\
\text { intestinais }\end{array}$ \\
\hline \multirow[t]{2}{*}{ Espirilos } & Forma de hélice & sifilis \\
\hline & Vibrião & Vibrio cholerae \\
\hline
\end{tabular}

(Fonte: Sanchez, 1997)

Tabela 1.5: Principais estruturas das bactérias

\begin{tabular}{|c|c|}
\hline Estrutura & Características \\
\hline Parede celular & Rígida e porosa; de peptidoglicano \\
\hline Membrana celular & $30-40 \%$ de lipidio e $60-70 \%$ de proteína \\
\hline Citoplasma & Protéico \\
\hline Área nuclear & $\begin{array}{l}\text { Sem membrana; cromossomo circular constituído por } 1 \\
\text { macromolécula de DNA }\end{array}$ \\
\hline Flagelos & Relacionados à locomoção \\
\hline Fimbrias & $\begin{array}{l}\text { Relacionadas à adesão (fator de colonização) e transferência de } \\
\text { material genético (conjugação) }\end{array}$ \\
\hline Esporos & $\begin{array}{l}\text { Protélcos; formas de resistência a agentes químicos e físicos; } \\
\text { estado latente }\end{array}$ \\
\hline Cápsula & Polissacarídia; protege a bactéria dos anticorpos \\
\hline
\end{tabular}

(Fonte: Sanchez, 1997) 
A reprodução bacteriana pode ocorrer de 02 modos:

(a) Cissiparidade (assexuada): divisão binária (bipartição), com freqüência média de 15 a 30 minutos;

(b) Conjugação (sexuada): transferência de material genético - contato físico entre organismos.

A nutrição bacteriana pode ser avaliada quanto à fonte de energia (luminosa ou química) e à natureza da fonte de carbono $\left(\mathrm{CO}_{2}\right.$ ou composto orgânico), de acordo com a Tabela 1.6.

Em relação ao crescimento em função do oxigênio disponível, as bactérias podem ser:

(a) Anaeróbias - crescem na ausência de $\mathrm{O}_{2}$ livre (exemplo: clostrídios);

(b) Anaeróbias facultativas - crescem tanto na presença como na ausência de $\mathrm{O}_{2}$ livre (exemplo: enterobactérias);

(c) Microaerófilas: crescem na presença de quantidades mínimas de $\mathrm{O}_{2}$ livre (exemplos: brucelas e meningococos).

Existem diversas doenças de transmissão hídrica causadas por bactérias. Na Tabela 1.7 é apresentada uma síntese das principais doenças bacterianas, suas características e agente etiológico.

\subsubsection{Doenças causadas por outros mícroorganismos}

Outro importante grupo de microorganismos patogênicos está relacionado aos protozoários. São organismos unicelulares, eucariontes e pertencentes ao Reino Protista.

A giardíase é uma doença relativamente comum, causada pelo protozoário flagelado Giardia lamblia, que causa infeç̧ão do intestino delgado superior (Sanchez, 1997). O indivíduo infectado pode eliminar mais de $10^{6}$ cistos por grama de fezes, sendo que poucos cistos ingeridos podem iniciar a infeç̧ão no ser humano. Os cistos de Giardia podem sobreviver por 02 meses no ambiente aquoso a $08^{\circ} \mathrm{C}$ (Sanchez, op. cit.). 
Tabela 1.6: Nutrição Bacteriana

\begin{tabular}{|l|c|c|c|}
\hline \multicolumn{1}{|c|}{ Tipo } & Fonte de energia & Fonte de carbono & Exemplo (gênero) \\
\hline $\begin{array}{l}\text { FOTOTRÓfICO } \\
\text { Fotolitotrófico } \\
\text { (autotrofico) }\end{array}$ & $\mathrm{Luz}$ & $\mathrm{CO}_{2}$ & Chromatium \\
\hline $\begin{array}{l}\text { Fotoorganotrófico } \\
\text { (heterotrófico) }\end{array}$ & $\mathrm{Luz}$ & Composto orgânico & Rhodopseudomonas \\
\hline $\begin{array}{l}\text { QuimiOTRófico } \\
\text { Quimiolitotrófico } \\
\text { (autotrófico) }\end{array}$ & $\begin{array}{c}\text { Oxidação de } \\
\text { composto orgânico }\end{array}$ & $\mathrm{CO}_{2}$ & Thiobacillus \\
\hline $\begin{array}{l}\text { Quimiorganotrófico } \\
\text { (heterotrófico) }\end{array}$ & $\begin{array}{c}\text { Oxidação de } \\
\text { composto orgânico }\end{array}$ & Composto orgânico & Escherichia \\
\hline
\end{tabular}

(Fonte: Sanchez, 1997) 
Tabela 1.7: Principais doenças causadas por bactérias

\begin{tabular}{|c|c|c|}
\hline Doença & Agente etiologico & Características \\
\hline Febre Tifóide & Salmonella typhi & $\begin{array}{l}\text { Doença infecciosa caracterizada por febre contínua, mal estar, manchas rosadas no } \\
\text { tronco, tosse, prisão de ventre e comprometimento dos tecidos linfóides; doença } \\
\text { restrita ao ser humano; taxa de mortalidade de } 10 \% \text { na ausência de tratamento }\end{array}$ \\
\hline Febre Paratifóide & Salmonella paratyphi A, B e C & Parecida com a febre tifóide, entretanto causa diarréia e é menos letal \\
\hline Outras Salmoneloses & S. typhimurium (mais comum) & 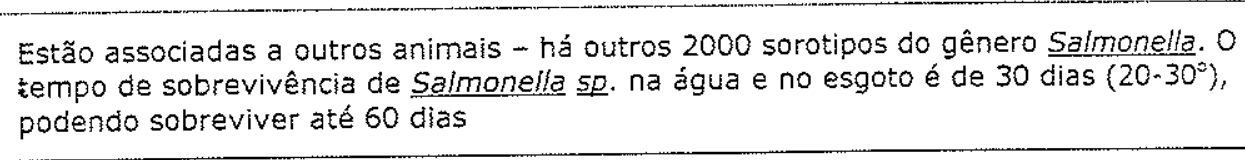 \\
\hline$\frac{\text { Escherichia coli }}{\text { enteroinvasoras }}$ & Escherichia coli & $\begin{array}{l}\text { Causam doenças localizadas principalmente no cólon (intestino) que se manifesta com } \\
\text { febre e diarréia mucóide e, muitas vezes, sanguinolenta }\end{array}$ \\
\hline $\begin{array}{l}\text { Escherichia coli } \\
\text { enterotoxigênicas }\end{array}$ & Escherichia coll & $\begin{array}{l}\text { Causam diarréia profusa e aquosa sem muco nem sangue, que duram menos que } 48 \\
\text { horas }\end{array}$ \\
\hline $\begin{array}{l}\text { Escherichia coli } \\
\text { enteropatogênicas clássicas }\end{array}$ & Escherichia colt & Relacionadas a surtos de diarréia em berçários \\
\hline Shigeloses & $\begin{array}{l}\text { S. dysenteriae S. flexneri, S. } \\
\text { boudii S. sonnei }\end{array}$ & \\
\hline Cólera & Vibrio cholerae & $\begin{array}{l}\text { Diarréia aguda que ocorre em surtos explosivos, com vômitos ocasionais, rápida } \\
\text { desidratação, acidose, cãibras musculares e colapso respiratório. Pode causar a morte } \\
\text { em periodo de } 48 \mathrm{~h} \text { em pessoas não tratadas }\end{array}$ \\
\hline
\end{tabular}

(Fonte: Sanchez, 1997) 
Outra doença comum causada por protozoário é a amebíase, causada pela Entamoeba histolytica, cuja infecção são muitas vezes assintomáticas (Sanchez, op.cit.). As enfermidades variam desde disenteria aguda e fulminante até diarréia sanguinolenta e mucóide. A E. histolytica é altamente resistente à desinfeç̧ão, sobrevivendo à concentração de até $100 \mathrm{mg} / \mathrm{L}$ de cloro.

Um outro protozoário que vem sendo pesquisado mais intensamente nos últimos anos é o Cryptosporidium. É um gênero da família Cryptosporiididae, subordem Elmerina, subclasse Coccidia. Existem 04 espécies conhecidas: $\underline{C}$. parvum (patogênica), C.muris, C. meleagridis e C. bailey (Mawdsley et al. 1996).

Cryptosporidium é um parasita protozoário capaz de causar diarréia crônica persistente no șer humano. Em pacientes aidéticos ou imunodeficientes, o Cryptosporidium pode invadir vários órgãos, podendo ser fatal. Atualmente, ele é considerado um patógeno emergente pelo aumento do número de casos relatados em humanos (Gamba et al., 1997).

O tempo de sobrevivência do Cryptosporidium fora do organismo humano não é conhecido. Trata-se de um protozoário resistente à desinfecção convencional (cloro). O tratamento térmico (fervura da água) a $100^{\circ} \mathrm{C}$ durante 05 minutos reduz a infectividade dos oocistos. A dose infectante de Cryptosporidium é relativamente baixa, em torno de 01 a 10 oocistos (Miller et al., 1986).

Os vírus também causam doenças transmitidas pela água, principalmente as gastroenterites (diarréia, vômito, desidratação e dores abdominais) e as enteroviroses (infeç̧ões assintomáticas até febre com paralisia, meningites e, muitas vezes, a morte). Outra doença causada por vírus é a hepatite ( $A$ e E), cuja gravidade e manifestações são variadas, podendo ser leve, moderada ou grave, aumentando, em geral, com a idade. 


\section{OBJETIVOS DA PESQUISA}

O objetivo principal desta pesquisa foi caracterizar os impactos causados pelos sistemas de saneamento in situ nas águas subterrâneas, do ponto de vista químico e microbiológico, no bairro Recanto Mônica, município de Itaquaquecetuba.

Visou também avaliar a influência do clima e dos aspectos sanitários sobre a concentração dos contaminantes nas águas subterrâneas e seus efeitos na população local

Comprovada a existência de contaminantes na água subterrânea acima dos limites estabelecidos pelos padrões de potabilidade, foram apresentadas medidas preventivas de desinfeç̧ão da água consumida pela população do bairro através de orientações aos moradores locais. 


\section{3. ÁREA DE ESTUdOO}

\subsection{Localização e acessos}

A área de estudo está localizada no município de Itaquaquecetuba, Região Metropolitana de São Paulo (RMSP).

A partir da Cidade de São Paulo, o acesso rodoviário é feito pela Rodovia Airton Senna (SP 70), até o trevo de Itaquaquecetuba. A área de estudo, bairro Recanto Mônica, localiza-se na região nordeste do município, divisa com o município de Mogi das Cruzes, cujo acesso interno é feito pela SP 88.

A Figura 3.1 mostra os principais acessos rodoviários e a localização da área de estudo.

\subsection{Características sócio-econômicas}

Um dos grandes problemas que vem ocorrendo na RMSP é a ocupação desordenada do solo urbano, tendo como conseqüência o surgimento $e$ aumento de favelas instaladás na beira de córregos, várzeas de rios e nas encostas íngremes sujeitas a desastres ambientais.

Terrenos públicos e particulares são irregularmente ocupados sem que os municípios adotem medidas corretas no que concerne ao controle da ocupação do espaço urbano. Como conseqüência, muitas famílias não têm saneamento básico e constata-se alto comprometimento ambiental: enchentes, erosão, assoreamentos de córregos, deslizamentos de terra, poluição do ar e das águas.

A carência de saneamento básico é o maior flagelo da RMSP, constituída por 39 municípios e 17.000 .000 de habitantes. Com a falta de saneamento básico, muitas famílias consomem água subterrânea captada através de poços rasos (cacimbas) e utilizam sistemas de saneamento in situ para tratar o esgoto produzido. 


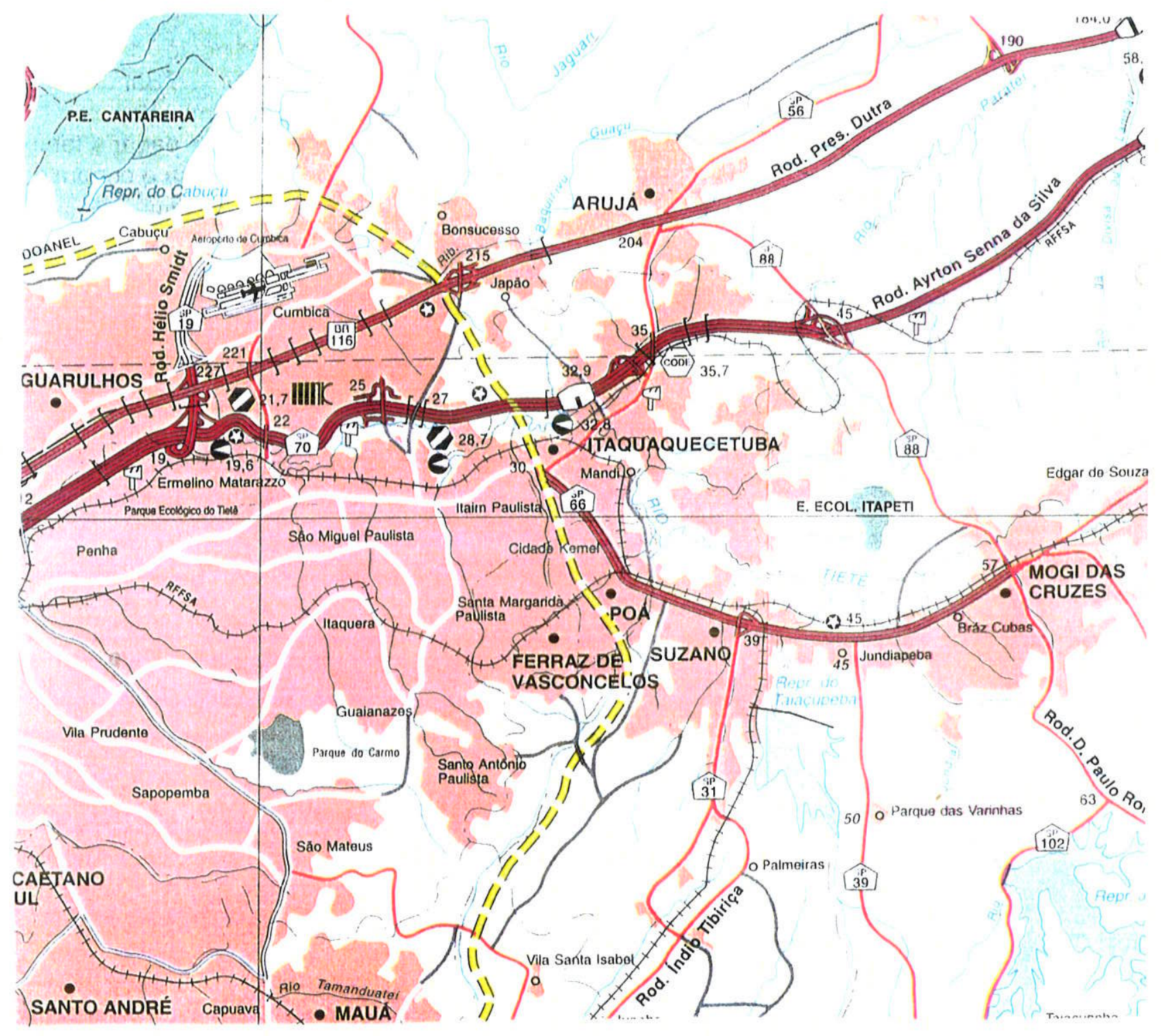

Figura 3.1 - Localização da área de estudo e principais acessos rodoviários 
Neste contexto está Itaquaquecetuba, cidade periférica à Capital Paulista, que teve crescimento demográfico acentuado num pequeno e recente intervalo de tempo. Dados da Fundação SEADE (1997) indicam que, em 1991, Itaquaquecetuba não figurava entre os 100 municípios mais populosos do Brasil, sendo que, em 1996, apareceu na $88^{a}$ posição, com crescimento anual de $6,86 \%$, bem superior ao de $0,35 \%$ observado na Capital do Estado (Espindola et al., 1997).

O setor industrial é a principal fonte de renda do município, compreendendo principalmente indústrias de pequeno e médio porte. A renda salarial é baixa, em torno de 01 salário mínimo mensal. O município também possui diversos estabelecimentos comerciais de pequeno porte.

O abastecimento de água atende cerca de $81 \%$ das economias residenciais, enquanto a rede de esgoto atinge apenas 35\% (SEADE, 1997). A população que não possui saneamento básico utiliza, em geral, fossas sépticas mal implementadas e consome água subterrânea, captada do aqüífero freático local através de poços rasos, muitas vezes com qualidade imprópria ao consumo humano sem prévio tratamento, contaminados pelos efluentes sanitários provenientes das próprias fossas.

\subsection{Características fisiográficas}

Itaquaquecetuba situa-se na Bacia Hidrográfica do Alto Tietê, cujo rio drena toda extensão do município. O clima da região é do tipo subtropical, com elevado índice pluviométrico, cuja precipitação é predominante no verão (estação chuvosa) e menos intensa no inverno (estação seca).

As características geomorfológicas do município de Itaquaquecetuba refletem as diferentes unidades geológicas que afloram na região. Os terrenos situados no contexto das rochas cristalinas possuem as maiores elevações e amplitude de relevo, com drenagens de padrão dendrítico a retangular. Quanto maior o grau de fraturamento dessas rochas, mais evidente é o padrão retangular das drenagens, com cristas e vales paralelos ao sistema de fraturas. Este padrão de relevo é denominado Relevo de Morros com Serras Restritas (IPT, 1981a). 
As extensas áreas cobertas pelos sedimentos terciários da Bacia de São Paulo possuem relevo suave com pequenas amplitudes (áreas de planícies). A densidade de drenagens é maior em sedimentos argilosos e menor em sedimentos arenosos, refletindo, desta forma, a permeabilidade do solo. Este padräo é classificado como Relevo colinoso (IPT, op. cit.), com colinas pequenas e espigões locais.

Os terrenos onde estão depositados os sedimentos recentes (quaternários) correspondem às áreas mais baixas, localizadas ao longo da várzea do Rio Tietê e de seus principais afluentes. São denominadas Planícies Aluviais.

No bairro Recanto Mônica, a amplitude topográfica é elevada, com altitudes que variam de 700 a $800 \mathrm{~m}$ acima do nível do mar.

As vertentes do bairro possuem perfil convexo a retilineo, com cristas mais ou menos alongadas nas cotas mais altas. O terreno é intensamente drenado, com diversos córregos aflorando nos vales. As cristas e os vales possuem atitude ENE, NNW (NW) e NNE (NE), refletindo as direções da foliação do embasamento rochoso (ENE) e dos sistemas de fraturas da rocha (NNW e NNE).

\subsection{Contexto geológico regional}

As rochas que afloram em Itaquaquecetuba são dos mais variados tipos e idades (IPT, 1981b). Entre as rochas pré-cambrianas, predominam os gnaisses graníticos e migmatitos (Complexo Embu, Grupo Açungui), intensamente cisalhados, incluindo gnaisses miloníticos em zonas de intensa movimentação tectônica. Localmente também afloram metassedimentos de variada granulação (micaxistos, metarenitos, metassiltitos e filitos) e metabasitos (anfibolitos, metadiabásio e metagabro).

Sedimentos terciários afloram em extensas áreas e pertencem à Bacia de São Paulo (Formações São Paulo, Resende e Itaquaquecetuba).

Ao longo da várzea do Rio Tietê e seus principais afluentes, ocorrem sedimentos quaternários de diversificada granulação (argila a cascalho). 
A Figura 3.2 mostra as principais unidades geológicas que afloram no município de Itaquaquecetuba.

O bairro Recanto Mônica situa-se no contexto de gnaisses graníticos, localmente migmatizados, que, quando preservados, exibem granulometria fina a média. A mineralogia principal é constituída por quartzo, plagioclásio, feldspato potássico e biotita.

Localmente, entretanto, são poucos os afloramentos de rochas, resumindo-se a alguns matacões em cortes de estradas e afloramentos em calha. Espesso manto de intemperismo (solo e rocha alterada) constitui o terreno, de granulação areno-siltosa e coloração avermelhada, com freqüentes bandamentos de coloração clara (minerais félsicos) e escura (minerais máficos) alternados. 


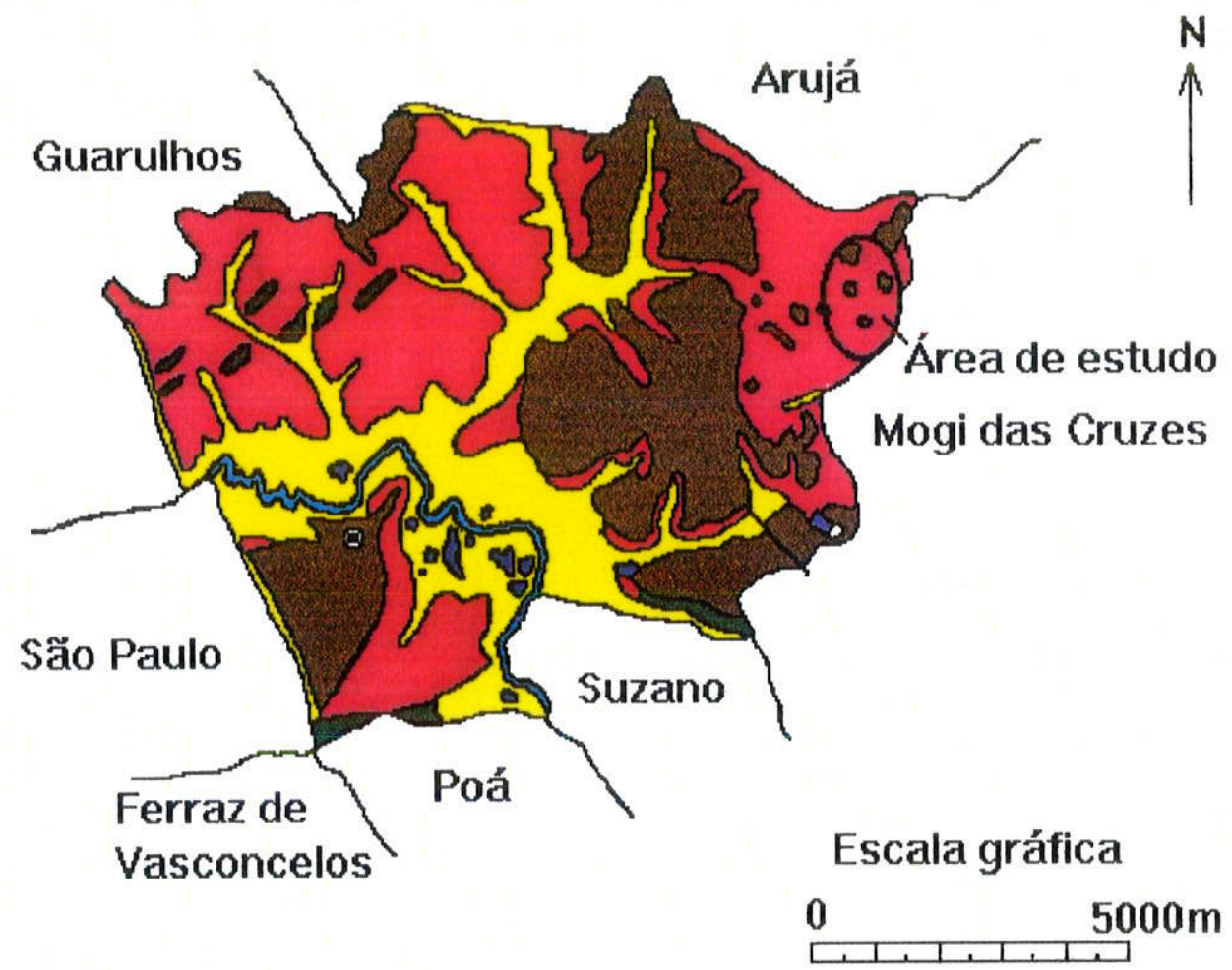

\section{LEGENDA}

Argilas, areias e cascalhos da Fm. São Paulo e da Fm. Caçapava

(Grupo Taubaté). Inclui depósitos elúvio-coluviais correlatos.

Migmatitos e gnáisses graníticos, podem achar-se cisalhados até gnaisses

miloníticos em zonas de movimentaçã̃o tectônica intensificada.

Aluvióes fluviais: argila, areia e cascalho.

Micaxisto e/ou meta-arenito de médio grau metamórfico, inclui também xistos miloníticos em zonas de movimentação tectônica.

Anfibolitos, metabasitos (metadiabásio, metagabro).

Filitos e/ou metassiltitos, inclui também milonitos em zonas de movimentação tectônica intensificada.

Rio Tietê.

Figura 3.2 - Principais unidades geológicas que afloram em Itaquaquecetuba (baseado em IPT, 1981b) 


\section{METODOLOGTA}

A fim de atingir os objetivos propostos nesta pesquisa, foram realizadas 07 (sete) atividades principais:

(a) Caracterização dos condicionantes hidrogeológicos da área investigada;

(b) Cadastramento de fossas e poços rasos no bairro Recanto Mônica;

(c) Definição dos pontos de monitoramento;

(d) Investigação indireta do aqüifero freático - Geofísica;

(e) Investigação direta do solo - sondagens;

(f) Ensaios de permeabilidade do solo;

(g) Análises laboratoriais e de campo.

As metodologias empregadas em cada atividade de investigação serão apresentadas neste capítulo.

\subsection{Condicionantes hidrogeológicos da área}

Os condicionantes hidrogeológicos na área do bairro Recanto Mônica estão relacionados ao relevo. As cristas topográficas e as drenagens na região de vales delimitam as áreas de recarga pluvial e de descarga das águas subterrâneas, respectivamente.

Todas as informações cartográficas desta pesquisa foram lançadas numa base topográfica de escala 1:5.000, a partir de uma planta confeccionada pela Prefeitura Municipal de Itaquaquecetuba. Na Figura 4.1 são apresentados os limites hidrogeológicos que definiram a área de investigação desta pesquisa, em função dos referidos elementos de relevo.

O limite norte da área é delimitado por um córrego (córrego norte), cujo traçado possui direção geral E-W e sentido leste de corrente. A região sul da área também é delimitada por uma drenagem (córrego sul), de direção $E-W$, com variação WSW no quadrante SW da área, e sentido de corrente para W a WSW, contrário ao córrego da região norte. 


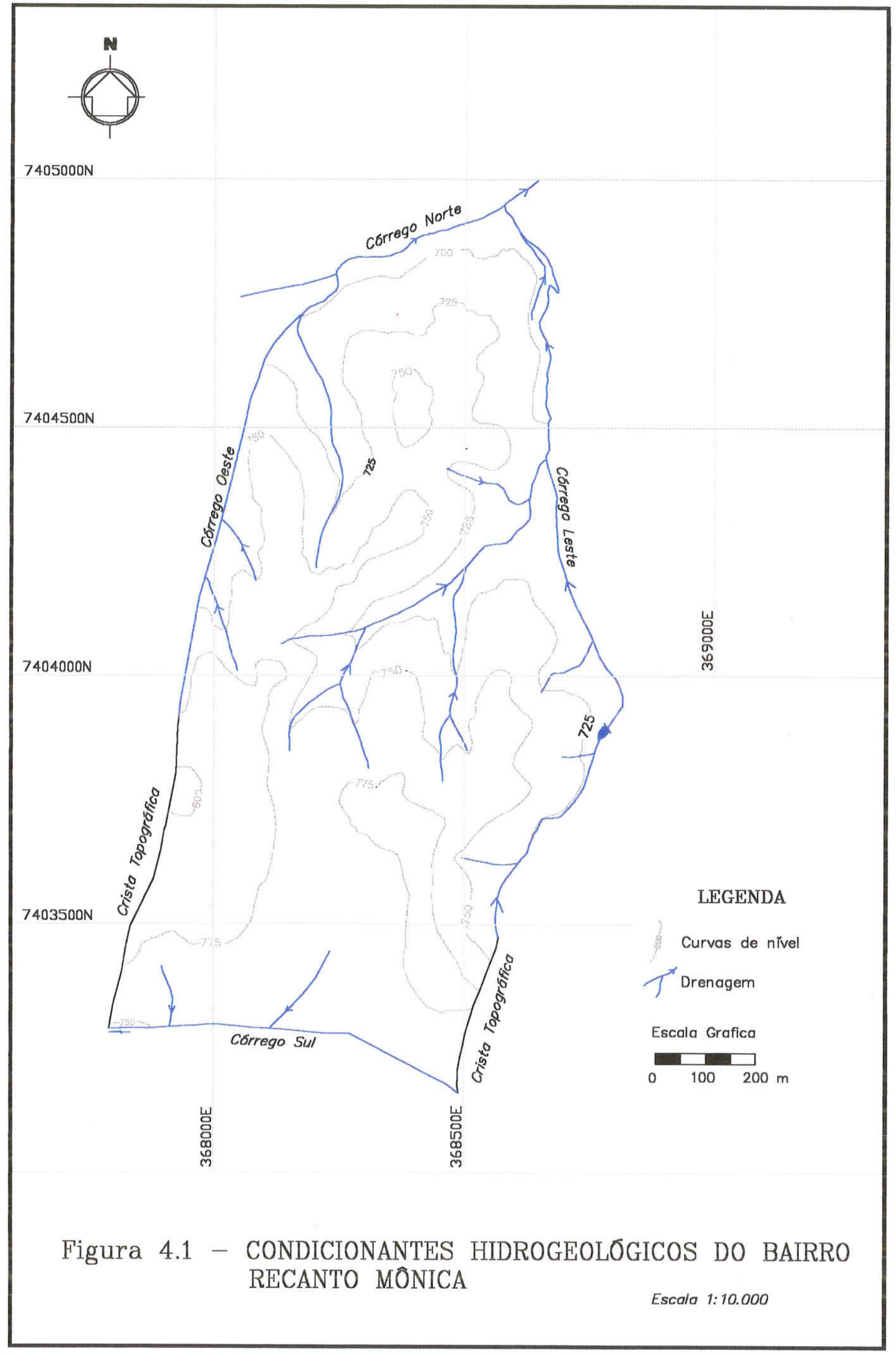


Os limites hidrogeológicos leste e oeste da área também apresentam simetria entre si. Nos quadrantes NE e NW da área, os limites hidrogeológicos são definidos por drenagens (córregos) afluentes do córrego norte. Os limites hidrogeológicos dos quadrantes SE e SW são definidos por cristas topográficas (divisores de águas).

Estes limites hidrogeológicos coincidem de maneira geral com os limites físicos do bairro Recanto Mônica. Todos os pontos de monitoramento definidos nesta pesquisa encontram-se dentro deste perímetro, cuja água subterrânea local é influenciada somente por fontes de contaminação inseridas nesta região.

No interior deste perímetro, foram definidas 05 vertentes principais, que representam compartimentos hidrogeológicos distintos do aqüífero freático local, cuja água subterrânea em cada vertente é influenciada somente por fontes de contaminação posicionadas nestes compartimentos.

\subsection{Cadastramento de fossas sépticas e poços rasos}

No bairro Recanto Mônica, existem aproximadamente $\mathbf{7 5 0}$ residências. Em geral, cada residência possui um poço raso (cacimba) e uma fossa. A Figura 4.2 mostra o posicionamento das residências no bairro.

Para se avaliar as características construtivas dos poços rasos e das fossas sépticas existentes no bairro, foi definido um universo de $\mathbf{5 2}$ residências nas quais foram avaliadas as características construtivas do sistema fossampoço. O critério de seleção dos poços e das fossas sépticas se baseou nos seguintes aspectos:

(a) distribuição uniforme pela área de estudo;

(b) localizados em todas as vertentes do bairro;

(c) posicionamento distinto em 03 porções das vertentes - topo (montante), meia vertente (posição intermediária) e baixada (jusante), alinhados entre si. 


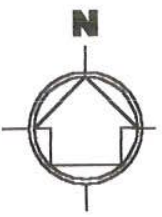

$7405000 \mathrm{~N}$

$7404000 N$

$7403500 \mathrm{~N}$

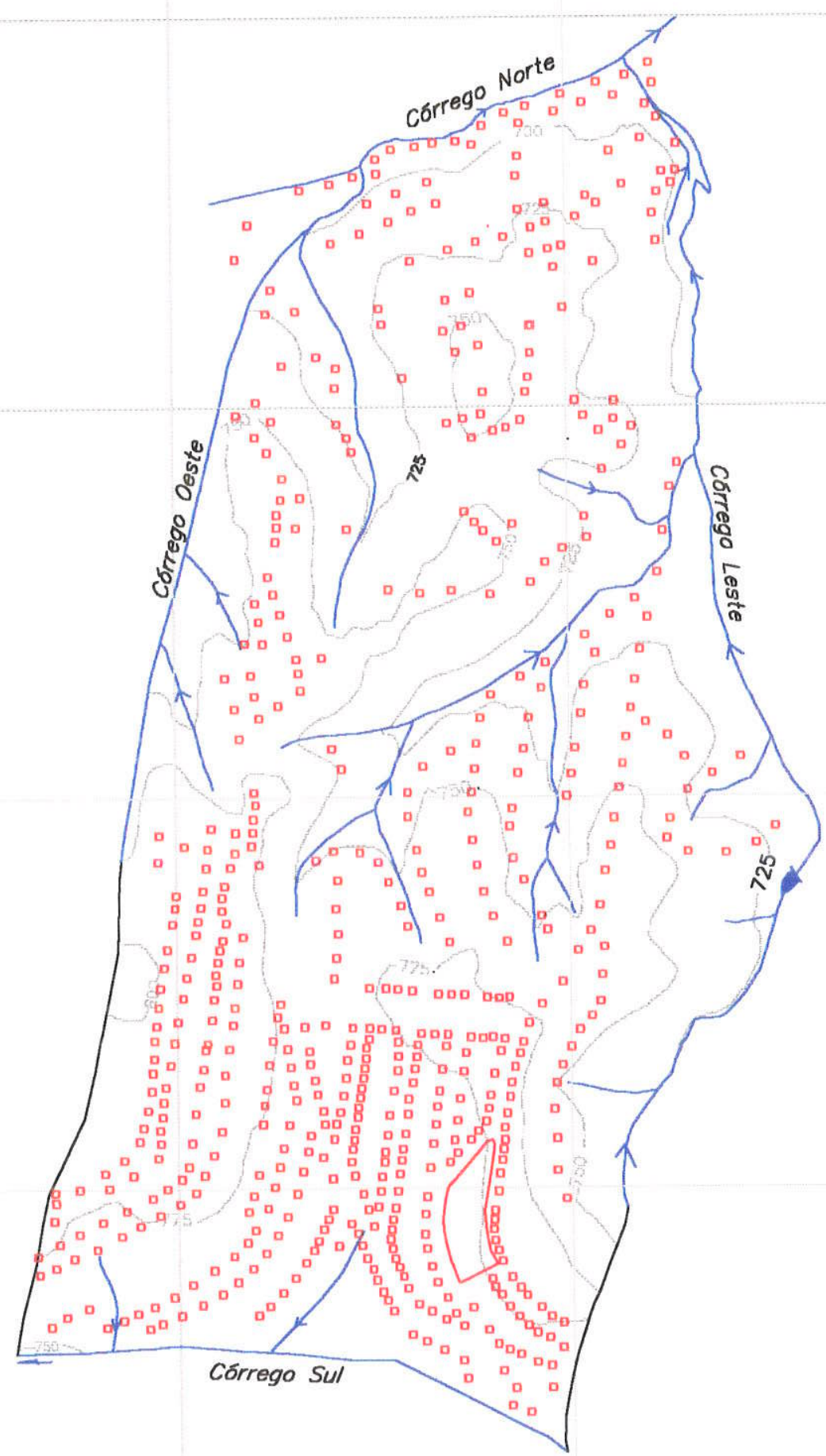

山्ㅇ
음
․

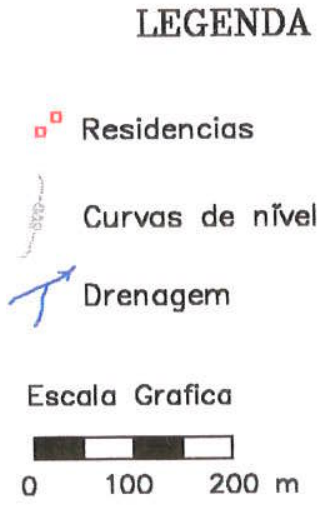

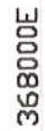

늠
1n
$\infty$
0
ल

Figura 4.2 - POSICIONAMENTO DAS RESIDENCIAS DO BAIRRO RECANTO MÔNICA

Escala 1:10.000 
Os dois primeiros critérios de seleção foram definidos com a finalidade de cobrir de maneira mais ampla possível a área do bairro Recanto Mônica. O terceiro critério visou possibilitar a comparação dos parâmetros monitorados (carga hidráulica e concentração química, por exemplo) em função dos diferentes compartimentos das vertentes e na mesma linha de fluxo da água subterrânea.

A profundidade do nível d'água dos 52 poços foi medida através de um medidor eletrônico de nível d’água. Através do posicionamento topográfico desses poços em mapa: (escala 1:5.000), foi possivel calcular a carga hidráulica em cada poço, subtraindo a profundidade do nível d'água da cota topográfica. Através da interpolação das cargas hidráulicas (cota do nível d'água) em planta, foi possível construir o mapa potenciométrico da área e verificar o sentido de fluxo da água subterrânea, verificando a inter-relação entre os poços cadastrados.

\subsection{Definição dos pontos de monitoramento}

Foram monitorados 15 poços rasos (cacimbas), 02 córregos e 02 fossas sépticas. O monitoramento foi realizado durante 01 ano hidrológico, de agosto de 1997 a julho de 1998, sob todas as estações climáticas do ano.

Foram realizados 03 tipos de análises nesta pesquisa: análises microbiológicas, análises químicas e análises físico-químicas in situ. Estas análises exigiram procedimentos de campo específicos (coleta e preservação de amostras), discutidos nos item 4.8 .

Na Tabela 4.1 são apresentados os parâmetros monitorados em cada tipo de análise e a freqüência de coleta no período monitorado.

Dentre os 52 poços cadastrados, foram escolhidos 15 poços rasos que foram monitorados periodicamente. Além de estarem distribuídos de forma regular pelo bairro Recanto Mônica, o principal critério de escolha foi o posicionamento destes poços nas 05 vertentes topográficas delimitadas. 
Tabela 4.1: Parâmetros analíticos e freqüência de amostragem

\begin{tabular}{|c|c|c|c|c|c|c|c|c|c|c|}
\hline \multirow[b]{2}{*}{ Tipo de análise } & \multicolumn{10}{|c|}{ DATA DE COLETA (01 ANO HIDROLÓGICO) } \\
\hline & 20.08 .1907 & 16.09 .1997 & 27.10 .1907 & 09.02 .1998 & 02.03 .1908 & 23031908 & 1604,098 & 08.051988 & 17.061008 & 2101998 \\
\hline \multicolumn{11}{|c|}{ Análises Microbiológicas } \\
\hline \multicolumn{11}{|l|}{15 Posos } \\
\hline Coliformes fecais e totais & $x$ & $x$ & $x$ & $x$ & $x$ & $x$ & $x$ & $x$ & $x$ & $x$ \\
\hline Colifagos & $x$ & $x$ & $x$ & $x$ & $x$ & $x$ & $x$ & $x$ & $x$ & $x$ \\
\hline Cryptosporidium & & $x$ & & $x$ & & $x$ & & $x$ & & \\
\hline Salmonella & & $x$ & & $x$ & & $x$ & & $x$ & & \\
\hline \multicolumn{11}{|l|}{02 córregos } \\
\hline Coliformes fecais e totais & & $x$ & & & $x$ & & & $x$ & & \\
\hline \multicolumn{11}{|l|}{02 Fossas } \\
\hline Cryptosporidium & & & & & & & $x$ & & $x$ & \\
\hline Salmonella & & & & & & & $x$ & & $x$ & \\
\hline \multicolumn{11}{|l|}{ Análises químicas } \\
\hline \multicolumn{11}{|l|}{15 Poços } \\
\hline Cátions e ânions & & $x$ & & & $x$ & & & & $x$ & \\
\hline \multicolumn{11}{|l|}{02 Córregos } \\
\hline Cátions e ânions & & & & & $x$ & & & & $x$ & \\
\hline \multicolumn{11}{|l|}{02 Fossas } \\
\hline Cátions e ânions & & & & & & & & & $x$ & \\
\hline \multicolumn{11}{|c|}{$\begin{array}{l}\text { Análises físico-químicas } \\
\text { (pocos) }\end{array}$} \\
\hline $\begin{array}{l}\text { Eh, ph, condutividade e } \\
\text { temperatura }\end{array}$ & & $x$ & & & $x$ & & & & $x$ & \\
\hline Alcalinidade & $x$ & $\mathrm{x}$ & $x$ & $x$ & $x$ & $x$ & $x$ & $x$ & $x$ & $x$ \\
\hline
\end{tabular}


Foram escolhidos 05 grupos de 03 poços rasos, cada grupo posicionado numa das 05 vertentes topográficas. Cada grupo possui um poço na região alta da vertente (poço montante), um segundo poço na região média da vertente (poço intermediário) e um terceiro poço na parte baixa da vertente (poço jusante). Estes grupos de 03 poços apresentam-se alinhados na vertente em que se encontram, perpendicularmente às cotas topográficas e na mesma linha de fluxo da água subterrânea, considerando o aqüifero freático homogêneo e isotrópico.

Como as fossas sépticas estão disseminadas em todas as vertentes do bairro Recanto Mônica, assumiu-se, por hipótese, que o poço montante seja menos influenciado pelos efluentes sanitários que o poço de meia vertente, que por sua vez sofre menos influência que o poço jusante, em processo conservativo e cumulativo de contaminação fecal originado pelo esgoto sanitário coletado pelas fossas sépticas e comuns.

Na Figura 4.3 são mostrados os poços, as fossas e os córregos monitorados.

\subsection{Investigação indireta do aquiífero freátíco - Geofísica}

Os métodos indiretos de investigação geofísica complementam os estudos hidrogeológicos na obtenção de dados sobre o solo e a água subterrânea. A Geofísica é uma ferramenta auxiliar na caracterização das dimensões do aqüífero freático, indicando a espessura de solo não saturado, a espessura da zona saturada e a profundidade do topo rochoso (base do aqüifero poroso).

Os métodos geofísicos, em geral, possuem maiores alcances de profundidade de investigação em comparação com os métodos de sondagem manual (trado) e menor custo quando comparado aos métodos mecanizados de sondagem. 


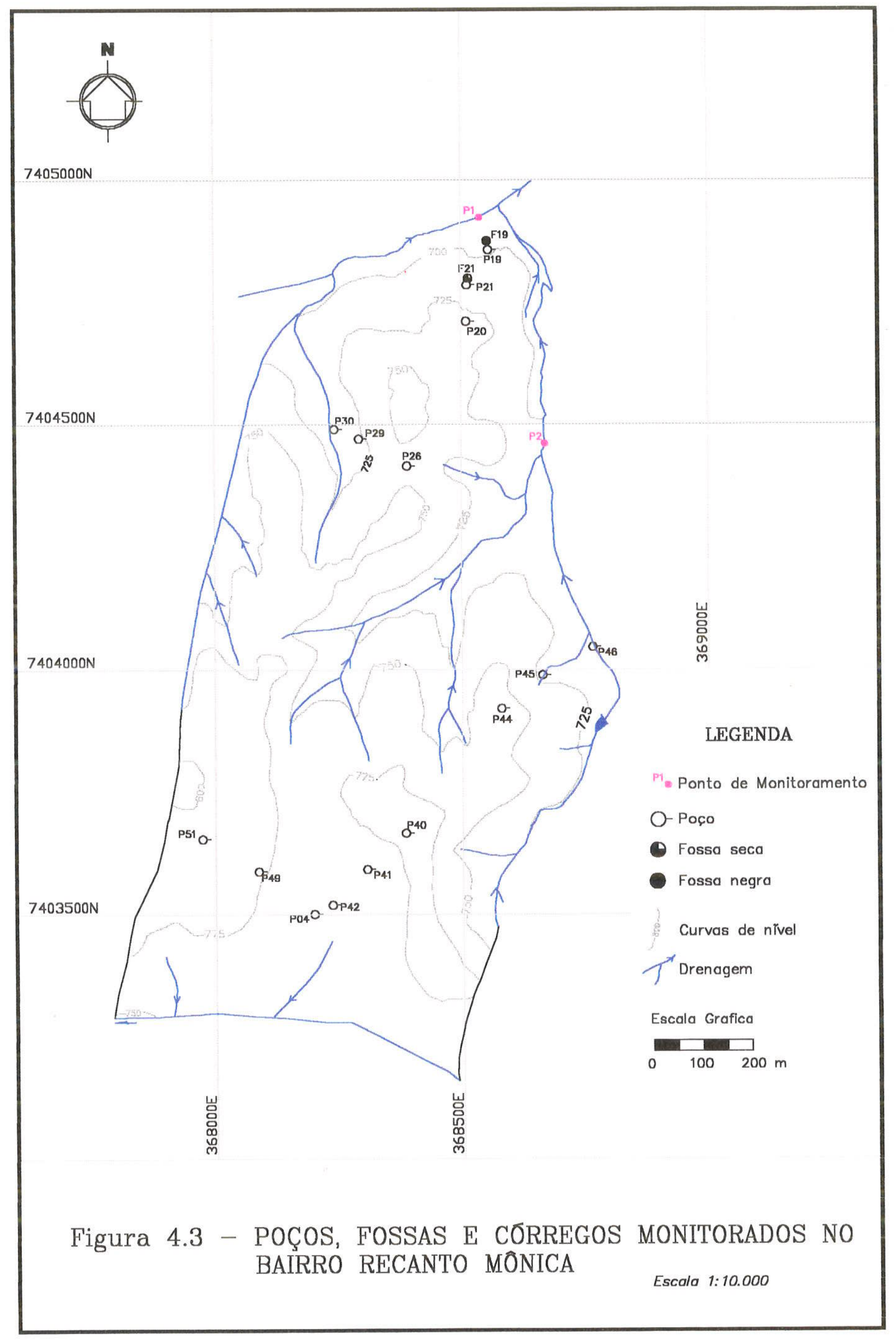


Nesta pesquisa, foi utilizado o método da eletrorresistividade, um dos mais versáteis da Geofísica Aplicada. A modalidade utilizada foi a sondagem elétrica vertical (SEV), que utiliza 02 grupos de eletrodos: 02 eletrodos de corrente $(A B)$ e 02 eletrodos de potencial $(M N)$, cravados na superfície do solo de maneira alinhada e interpolada denominada arranjo Schumberger, esquematicamente mostrado na Figura 4.4.

Os eletrodos $A B$ injetam corrente elétrica (I) no solo, produzindo uma diferença de potencial $(\Delta V)$ registrada nos eletrodos $M N$ centrais. $A$ profundidade de investigação é função direta do espaçamento dos eletrodos de corrente, sendo que o arranjo dos eletrodos deve ser $A B / 5>M N$. Com isso, pode-se calcular a resistência elétrica média de uma determinada porção do solo em diferentes profundidades pela relação $\Delta V$ / I, medidos a cada leitura em distâncias regularmente variadas de $A B$. O equipamento de leitura utillzado fol o TECTROL."

Os valores obtidos podem ser expressos num gráfico, na forma de resistividade aparente ( $\rho a)$ em função do espaçamento dos eletrodos de corrente. Nesta pesquisa foi utilizado o software RESIST ${ }^{\mathrm{rm}}$, que processa os valores de resistividade elétrica $x$ espaçamento $A B$ automaticamente. Este programa constrói a curva de resistividade aparente e calcula o número de camadas que apresentam resistividades elétricas distintas e a espessura relativa de cada uma.

A resistividade elétrica é uma grandeza física inversa à condutividade elétrica, tendo como unidade de medida ohm . $\mathbf{m}$.

\subsection{Investigação direta do solo - sondagens}

Foram realizadas 06 sondagens com trado manual de 04" de diâmetro, para caracterização geológica do solo de alteração local (descrição visualtáctil). Foram descritos os seguintes parâmetros: granulação, cor, mineralogia, umidade e resistência mecânica. Também foi observado a existência de odor, manchas ou substâncias anômalas, indicativos de contaminação. 


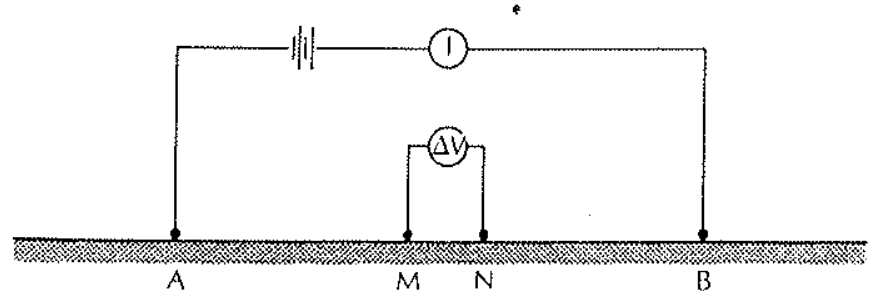

Figura 4.4 - Arranjo Schumberger - sondagem elétrica vertical 
Foram executadas 06 sondagens a trado em 02 vertentes topográficas distintas, cada vertente com 03 furos alinhados entre si ao longo do caimento topográfico do relevo (montante, meia vertente e baixada). A profundidade de investigação foi até o nível d’água local, início da zona saturada do solo.

A disposição desses furos de sondagem e seus respectivos resultados visaram (1) avaliar as variações geológicas verticais e horizontais do solo ao longo dessas vertentes; (2) auxiliar na interpretação dos dados obtidos através do levantamento geofísico.

\subsection{Ensaios de permeabilidade em solo}

Foram realizados 05 ensaios de permeabilidade na zona não saturada do solo, localizados na porção média de cada vertente topográfica investigada. A modalidade de ensaios foi de rebaixamento acima do nível d'água (carga variável), de acordo com a metodologia descrita pela Associação Brasileira de Geologia de Engenharia (ABGE, 1996). Estes ensaios visaram determinar a condutividade hidráulica $(K)$ do solo, parâmetro importante para caracterizar o material geológico e auxiliar no cálculo da velocidade da água subterrânea local.

Foram realizados furos de 02 metros de profundidade com trado manual de 04" de diâmetro. Esta profundidade é compatível com a profundidade média das fossas sépticas existentes no bairro Recanto Mônica.

O ensaio de infiltração consiste em introduzir água no furo até seu nível superficial durante aproximadamente 10 minutos, a fim de promover uma condição de saturação do solo ao redor do furo.

Em seguida, é cessada a fonte de água e monitorado o rebaixamento da coluna d'água em intervalos regulares de tempo, durante 30 minutos ou até atingir $20 \%$ da coluna d'água inicial. As leituras de nível d'água foram feitas através de um medidor eletrônico da marca Solinst ${ }^{\circledR}$.

O cálculo de $K$ foi executado através da seguinte equação:

$K=d h / d t \cdot(r / R)^{2}$ 
onde: $\quad d h=$ variação do nível d'água no furo durante o ensaio $[\mathrm{L}]$

$\mathrm{dt}=$ intervalo de tempo de duração do ensaio [T]

$r=$ raio do furo [L]

$R=$ raio da parábola com vértice no centro do furo, na altura do nível d'água inicial $(t=0)$, dada pela equaçăo $R^{2}+R-h=0$ (em metros) [L]

$\mathrm{K}=$ condutividade hidráulica $[\mathrm{L}] \times[\mathrm{T}]^{-1}$

A Figura 4.5 mostra de maneira esquemática a representação do ensaio de rebaixamento.

Cada valor de $\mathrm{K}$ determinado foi associado à vertente onde foi realizado o ensaio. A Figura 4.6 mostra o posicionamento dos ensaios de permeabilidade executados.

\subsection{Velocidade média da água subterrânea}

A partir da condutividade hidráulica calculada em cada vertente topográfica (item 4.6), foi calculada a velocidade média da água subterrânea em cada um desses trechos, utilizando o gradiente hidráulico entre 02 poços alinhados e em posições extremas em cada vertente (montante / jusante).

O gradiente hidráulico fọi calculado pela seguinte equação (Fetter, 1994):

$i=d H / d x$

onde: $\quad d H=$ diferença entre as cargas hidráulicas de dois poços [L]

$\mathrm{dx}=$ distância horizontal entre os dois poços [L]

$i=$ gradiente hidráulico (grandeza adimensional)

A velocidade média da água subterrânea foi calculada pela seguinte equação:

$v=k \cdot i / n_{e}$

onde: $\quad K=$ condutividade hidráulica $[\mathrm{L}] \times[\mathrm{T}]^{-1}$

$\mathbf{i}=$ gradiente hidráulico (grandeza adimensional)

$n_{e}=$ porosidade efetiva (grandeza adimensional)

$v=$ velocidade média $[\mathrm{L}] \times[\mathrm{T}]^{-1}$

A porosidade efetiva está relacionada à região intergranular do solo capaz de ser preenchida pela água subterrânea, expressa em percentagem. 


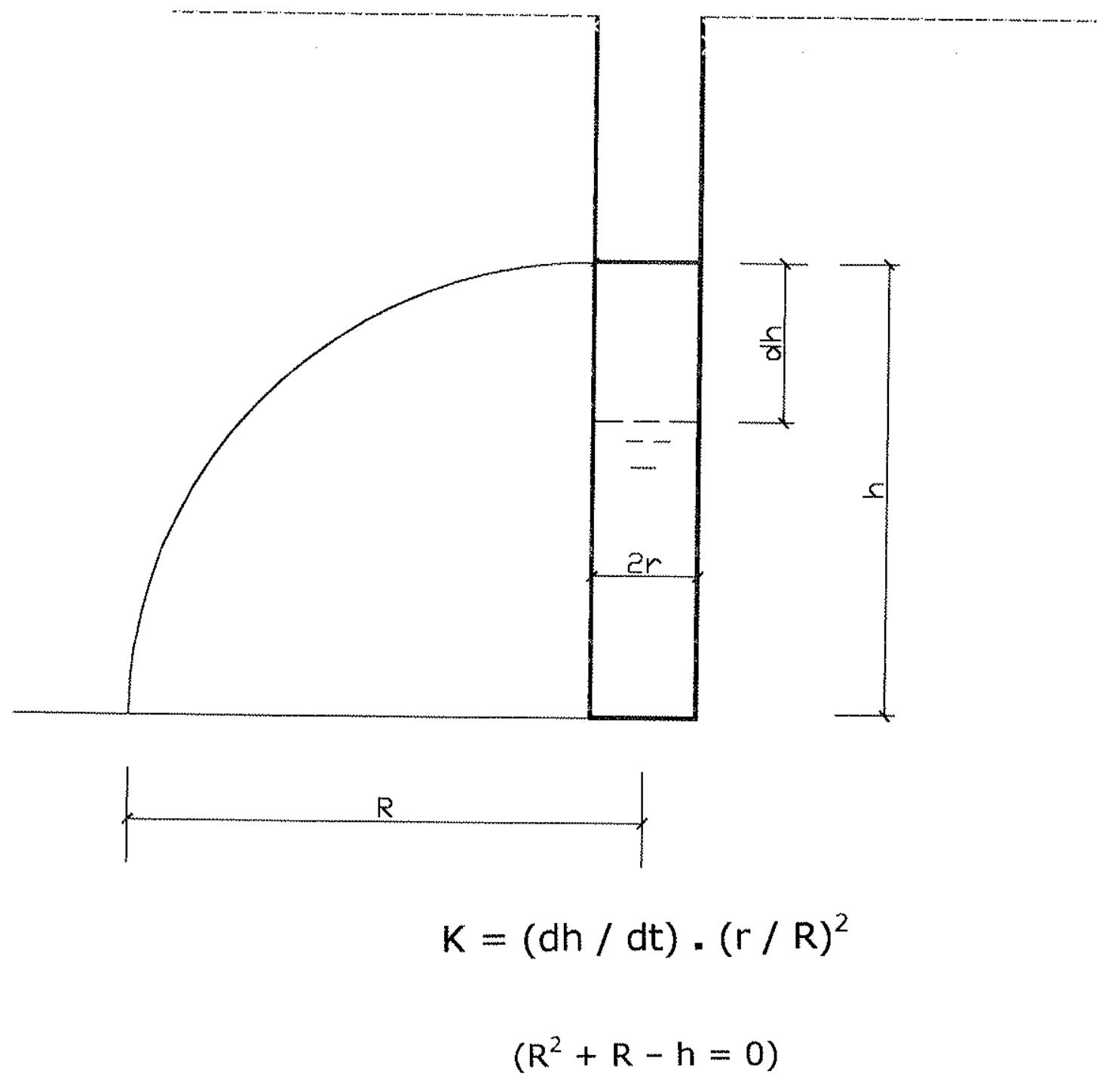

Figura 4.5 - Representação esquemática do ensaio de rebaixamento (ABGE, 1996) 


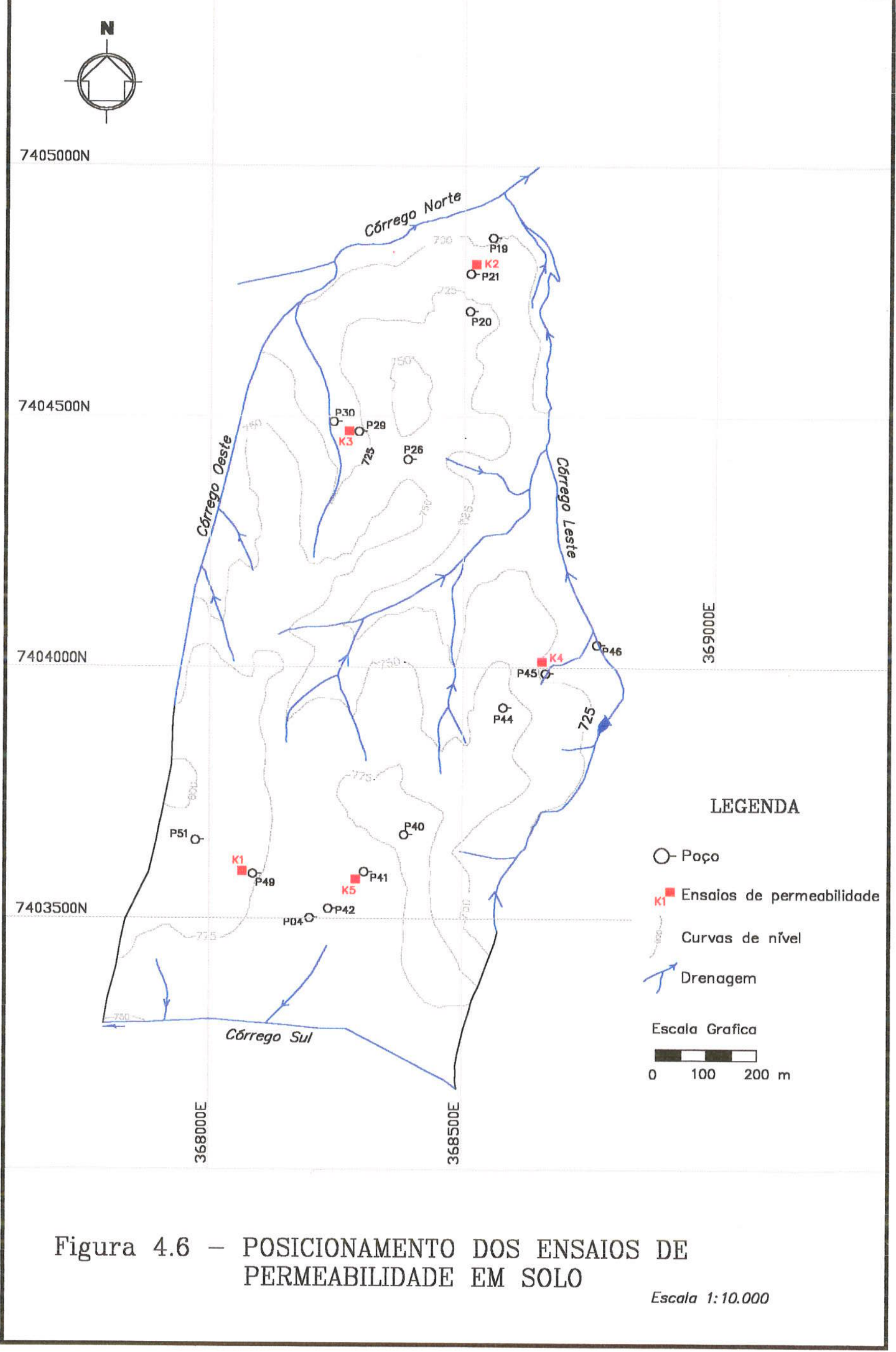




\subsection{Análises laboratoriais e de campo}

\subsubsection{Análises microbiológicas}

As análises microbiológicas foram realizadas no Laboratório de Microbiologia Ambiental do. Instituto de Ciências Biomédicas da Universidade de São Paulo (ICB / USP).

Foram analisadas amostras de água subterrânea (15 poços rasos), de água superficial (02 córregos) e de esgoto sanitário (02 fossas comuns). Em relação aos poços rasos, as amostras de água foram coletadas, em geral, pelo mesmo método utilizado pelos usuários dos poços, a fim de preservar as características da água consumida pela população.

Nos poços que possuíam bomba, a mesma era ligada minutos antes da coleta para permitir a circulação da água pela mangueira acoplada à bomba. A mangueira era então desconectada entre a bomba e a caixa d'água a fim de coletar a água proveniente diretamente do poço.

Nos poços que năo possuíam bomba, a coleta de água era feita manualmente através de baldes acoplados a sarilhos utilizados pelos moradores. Quando a bomba estava quebrada ou quando o balde não estava acoplado ao sarilho, era utilizado um coletor metálico de alumínio (fornecido pelo laboratório), lavado com água destilada, esterilizado com álcool etílico e posteriormente flambado cada vez que era utilizado, a fim de evitar contaminações cruzadas.

Nos córregos, a coleta era feita diretamente com os frascos fornecidos pelo laboratório para análise dos parâmetros microbiológicos. Nas fossas comuns, a coleta de esgoto sanitário foi feita com o coletor de alumínio esterilizado.

Nos procedimentos de coleta, foram utilizadas luvas descartáveis de látex e frascos descartáveis apropriados para cada parâmetro analítico.

Nos itens seguintes, serão discutidos os parâmetros microbiológicos e as técnicas analíticas empregadas. 


\subsubsection{Coliformes Totais e Fecais}

Os coliformes são bactérias indicadoras de contaminação fecal, pois ocorrem no intestino humano e podem persistir por determinado tempo no ambiente aquático.

Segundo Sanchez, (1997), coliformes são bacilos gram negativos, aeróbios ou anaeróbio facultativos, não formadores de esporos, que fermentam lactose com produção de gás em 24 a 48 horas a $35^{\circ} \mathrm{C}$. Estão incluídos os gêneros Escherichia, Enterobacter, Citrobacter e Klebsiella. Entretanto, $95 \%$ dos coliformes fecais são da espécie Escherichia coli.

Existem alguns requisitos para que um microoganismo seja indicador de contaminação fecal (Sanchez, op. cit.):

(a) Presentes no intestino humano ou de animais de sangue quente $e$, conseqüentemente, no esgoto doméstico;

(b) Sua densidade populacional deve ter relação direta com o grau de contaminação fecal (há proporção de 300.000 .000 de organismos por grama de fezes);

(c) Incapazes de se multiplicar no ambiente aquático ou, pelo menos, não mais que as bactérias entéricas;

(d) Serem mais resistentes que os patógenos;

(e) Serem quantificáveis por métodos simples, rápidos e eficientes de laboratório.

A técnica analítica utilizada foi a dos Tubos Múltiplos, que consiste na inoculação de volumes decrescentes de uma amostra previamente homogeneizada em meio de cultura adequado ao crescimento dos microoganismos pesquisados, sendo cada volume inoculado em uma série de tubos. Através de diluições sucessivas da amostra, são obtidos inóculos cuja semeadura fornece resultados negativos em pelo menos um tubo da série. A combinação de resultados positivos e negativos permite a obtenção de uma estimativa da densidade original da população, expressa em NMP - Número Mais Provável (Sanchez, op. cit.). 
Em relação à coleta, as amostras de água (aproximadamente $100 \mathrm{~mL}$ ) foram armazenadas em frascos plásticos, estéreis, acondicionados em caixa térmica sob refrigeração até serem entregues ao laboratório. O prazo máximo de armazenamento das amostras foi de 24 horas.

\subsubsection{Cryptosporidium}

A técnica analítica empregada foi a concentração por floculação de $10 \mathrm{~L}$ de amostra de água com carbonato de cálcio. As amostras coletadas em campo, armazenadas em balão volumétrico, foram posteriormente alcalinizadas em laboratório com hidróxido de sódio, em torno de pH 10, no mesmo dia da coleta. A adição de carbonato de sódio gera uma precipitado que é posteriormente filtrado. Este material foi analisado pelo teste de imunoflorescência para verificar a presença deste patógeno.

\subsubsection{Salmonella}

Para avaliar a presença de Salmonella sp, $05 \mathrm{~L}$ de água são filtrados em campo através de uma membrana de celulose de 0,45 $\mu \mathrm{m}$ de abertura. Esta membrana é colocada em meio de enriquecimento seletivo, Selenito Cistina, e incubada até 05 dias. Uma alíquota é plaqueada em meio agar X.L.D. (Agar Xilose-Lisina-Desoxicolato), cujas colônias de coloração negra são isoladas para identificação bioquímica e sorológica.

\subsubsection{Colifagos}

Esta técnica está baseada no fato de que colifagos (vírus) infectam e se multiplicam em células de E. coli. Como as células são lisadas, áreas visivelmente claras, conhecidas como placas de lise, indicam a presença do colifago. O resultado é obtido pela soma destas placas de lise e é expresso em colifagos / $100 \mathrm{~mL}$.

\subsubsection{Análíses químicas}

Ao longo do monitoramento das águas subterrâneas e superficiais, foram realizadas 03 campanhas de coleta de água para análises químicas, de acordo com a freqüência mostrada na Tabela 4.1 . 
Nas duas primeiras campanhas, as amostras foram analisadas no Laboratório de Hidroquímica II do Centro de Pesquisas de Águas Subterrâneas (CEPAS) do IGC / USP. Os parâmetros analisados, as metodologias empregadas e os equipamentos utilizados estão descritos na Tabela 4.2.

As análises químicas da terceira campanha foram realizadas num laboratório particular (CEIMIC Análises Ambientais S/C Ltda.). Neste monitoramento, foram analisadas espécies químicas da série nitrogenada e o ânion cloreto. A Tabela $\mathbf{4 . 3}$ mostra os parâmetros analisados, as metodologias e sua descrição.

O amônio e a amônia foram analisados como nitrogênio amoniacal. Suas concentrações foram calculadas pelas seguintes equações (proporções estequiométricas):

$$
\begin{aligned}
& \mathrm{NH}_{3(\mathrm{~g})}=\text { NAmoniacal }: 1,22 \\
& \mathrm{NH}_{4}{ }^{+}=\text {NAmoniacal } \cdot 1,29
\end{aligned}
$$

As amostras de água foram coletadas em frascos plásticos descartáveis de $150 \mathrm{~mL}$ de capacidade. As amostras coletadas foram acondicionadas em caixas térmicas sob refrigeração $\left(04{ }^{\circ} \mathrm{C}\right)$ até a entrega ao laboratório responsável.

Nos frascos que receberam amostras para análises de cátions, foi previamente adicionado ácido concentrado (cerca de 0,2 $\mathrm{mL}$ ) para facilitar as coletas de campo.

De cada poço raso, foram coletadas 03 alíquotas: um frasco de amostra preservada em ácido sulfúrico ( $\mathrm{pH}$ 02) para análise de sódio e potássio; um frasco de amostra preservada em ácido nítrico ( $\mathrm{pH}$ 02), para análise dos demais cátions; um terceiro frasco de amostra sem preservante para análise dos ânions. A adição de ácido nas amostras foi utilizada para manter os íons em solução nas amostras de água coletadas, evitando sua precipitação (CETESB, 1991). 
Tabela 4.2 - Parâmetros, metodologia e equipamentos analíticos (Laboratório de Hidroquímica II - CEPAS)

\begin{tabular}{|c|c|c|}
\hline Parametro Analítico & Metodologia & Equipamento \\
\hline $\begin{array}{l}\mathrm{F}^{-}, \mathrm{Cl}^{-}, \mathrm{NO}_{2}{ }^{-}, \mathrm{NO}_{3}{ }^{-}, \mathrm{Br}^{-}, \mathrm{PO}_{4}{ }^{2-} \\
\text { e } \mathrm{SO}_{4}^{2-}\end{array}$ & Cromatografia líquida & DIONEX $2010 \mathrm{i}$ \\
\hline $\mathrm{Na}^{+} \mathrm{eK}^{+}$ & Fotometria de chama & Fotômetro B 262 Micronal \\
\hline $\begin{array}{l}\mathrm{Cu}^{2+}, \mathrm{Pb}^{2+}, \mathrm{Zn}^{2+}, \mathrm{Fe}_{\text {total }} \\
\mathrm{Cr}_{\text {total }}, \mathrm{Mn}^{2+}, \mathrm{Ni}^{2+}, \mathrm{Ba}^{2+}, \mathrm{Al}^{3+}, \\
\mathrm{Sr}^{2+}, \mathrm{Ca}^{2+} \text { e } \mathrm{Mg}^{2+}\end{array}$ & Espectrofotometria & $\begin{array}{l}\text { Aparelho de absorção } \\
\text { atômica CGAA } 7000 \mathrm{BC}\end{array}$ \\
\hline
\end{tabular}

Tabela 4.3 - Parâmetros e metodologia analítica (CEIMIC Análises Ambientais)

\begin{tabular}{|c|c|c|}
\hline Parametro Analítico & Metodologia & Descrição \\
\hline $\mathrm{Cl}^{-}$ & Standard Methods $4500 \mathrm{~B} \mathrm{Cl}$ & Método Titrimétrico \\
\hline $\mathrm{NO}_{3}{ }^{-}$ & $E P A 353.3 \mathrm{NO}_{3}{ }^{-}$ & Método Colorimétrico \\
\hline $\mathrm{NH}_{4}{ }^{+}$ & $E P A 350.2 \mathrm{~N}$-Amoniacal & Método Titrimétrico \\
$\mathrm{NH}_{3(\mathrm{~g})}$ & $E P A 350.2 \mathrm{~N}$-Amoniacal & Método Titrimétrico \\
\hline
\end{tabular}




\subsubsection{Análises físico-químicas in situ}

As análises físico-químicas in situ foram realizadas durante a coleta de amostras de água para análises químicas, como mostrado na Tabela 4.1. Os parâmetros analisados foram:

(a) $\mathbf{p H}$ : potencial hidrogeniônico;

(b) Eh: potencial de redução, expresso em $\mathrm{mV}$;

(c) Condutividade elétrica, expressa em $\mu \mathrm{S} / \mathrm{cm}$;

(d) Temperatura $\left({ }^{\circ} \mathrm{C}\right)$.

$\mathrm{Na}$ Tabela 4.4 são descritos os equipamentos utilizados para medição desses parâmetros em campo.

A alcalinidade, outro parâmetro determinado in situ, fol avaliada durante todas as coletas. Este parâmetro representa a capacidade que uma solução possui de neutralizar ácidos num dado $\mathrm{pH}$ de viragem, utilizando métodos titulométricos (Hipólito, 1996).

Nesta pesquisa foi determinada a alcalinidade total ou completa, onde são calculadas as concentrações de $\mathrm{HCO}_{3}{ }^{\circ}, \mathrm{CO}_{3}{ }^{2-}$, e $\mathrm{OH}^{-}$, para $\mathrm{pH}$ ligeiramente ácido e até 05. Para realizar a titulação, foi utililizado o indicador misto, mistura do verde de bromo cresol $0,1 \%$ e vermelho de metila $0,2 \%$, na proporção de 3:1. O pH de viragem é 5,1 $(\mathrm{pH}<5,1$, cor vermelha; $\mathrm{pH}>5,1$, cor verde). A titulação foi feita com ácido sulfúrico $0,10 \mathrm{~N}$. O cálculo da alcalinidade total pode ser expresso pela seguinte equação:

$$
\begin{aligned}
& \mathrm{mHCO}_{3}(\mathrm{mg})=\mathrm{NH}_{2} \mathrm{SO}_{4} \cdot \mathrm{VH}_{2} \mathrm{SO}_{4}(\mathrm{~mL}) \cdot 61,0174 \cdot 10^{3} / \text { Vamostra }(\mathrm{mL}) \\
& \text { onde: } \quad \mathrm{m}=\text { molaridade } \\
& \qquad \mathrm{v}=\text { volume }
\end{aligned}
$$

Como usualmente a alcalinidade é expressa em ppm de $\mathrm{CaCO}_{3}$, multiplica-se o valor de $\mathrm{mHCO}_{3}^{-}$pelo fator 0,8202 :

$$
\left[\mathrm{CaCO}_{3}\right](\mathrm{ppm})=\mathrm{mHCO}_{3}^{-} \cdot 0,8202
$$


Tabela 4.4 - Equipamentos utilizados para análises físico-químicas in situ

\begin{tabular}{|c|c|}
\hline \multirow{2n}{*}{ Parâmetro } & Equipamento \\
\hline $\mathrm{pH}$ & HANNA Instruments - Watercheck \\
\hline $\mathrm{Eh}$ & ORP Testrim OAKTON \\
\hline Condutividade elétrica & HANNA Instruments - Watercheck \\
Temperatura & Termômetro Jenaer Normalglas JUMO \\
\hline
\end{tabular}




\section{RESULTADOS}

\subsection{Características sanitárias}

A partir do cadastramento das 52 residências distribuídas pelo bairro Recanto Mônica (item 4.2), verificou-se que os poços rasos (cacimbas) possuem 1,0 m de diâmetro interno, revestidos com manilhas de concreto em pelo menos $1 / 3$ de sua extensão. A profundidade média dos poços cadastrados é de 11,5 metros.

Usualmente os poços possuem proteção sanitária, construída com tijolos na sua porção superior (1,10 m de diâmetro externo), sobressalente 0,50 $\mathrm{m}$ acima do solo e lacrada com tampa de concreto, para impedir a entrada de águas pluviais.

Em $75 \%$ dos casos, a captação de água é feita através de bomba de pequena potência; $25 \%$ das famílias cadastradas captam a água manualmente, através de baldes acoplados em sarilhos.

Quanto à desinfecção da água, em $42 \%$ dos casos a água era clorada irregularmente e em $8 \%$ de forma permanente, enquanto que em $50 \%$ não havia tratamento. Quando efetuada, a cloração era feita nos próprios poços, nas caixas e/ou filtros d'água. Este levantamento estatístico foi realizado no início da pesquisa, juntamente com o cadastramento dos poços. No decorrer do estudo, a população foi informada sobre procedimentos corretos de desinfecção da água, com objetivo de reverter este quadro, diminuindo a incidência das doenças causadas pelo consumo de água contaminada. Este assunto será apresentado e discutido no capítulo 6.

Em relação aos sistemas de saneamento in situ, $95,12 \%$ das residências cadastradas possuem fossas comuns, sendo $17,07 \%$ fossas negras (lençol freático aflorante), e $78,05 \%$ do tipo fossas secas. Apenas $4,88 \%$ das residências possuem fossas sépticas rudimentares, construídas com padrões próximos aos estabelecidos pelas normas da ABNT.

A Figura 5.1 mostra a distribuição dos poços e fossas cadastrados. No caso das fossas, são apresentadas suas características sanitárias. 


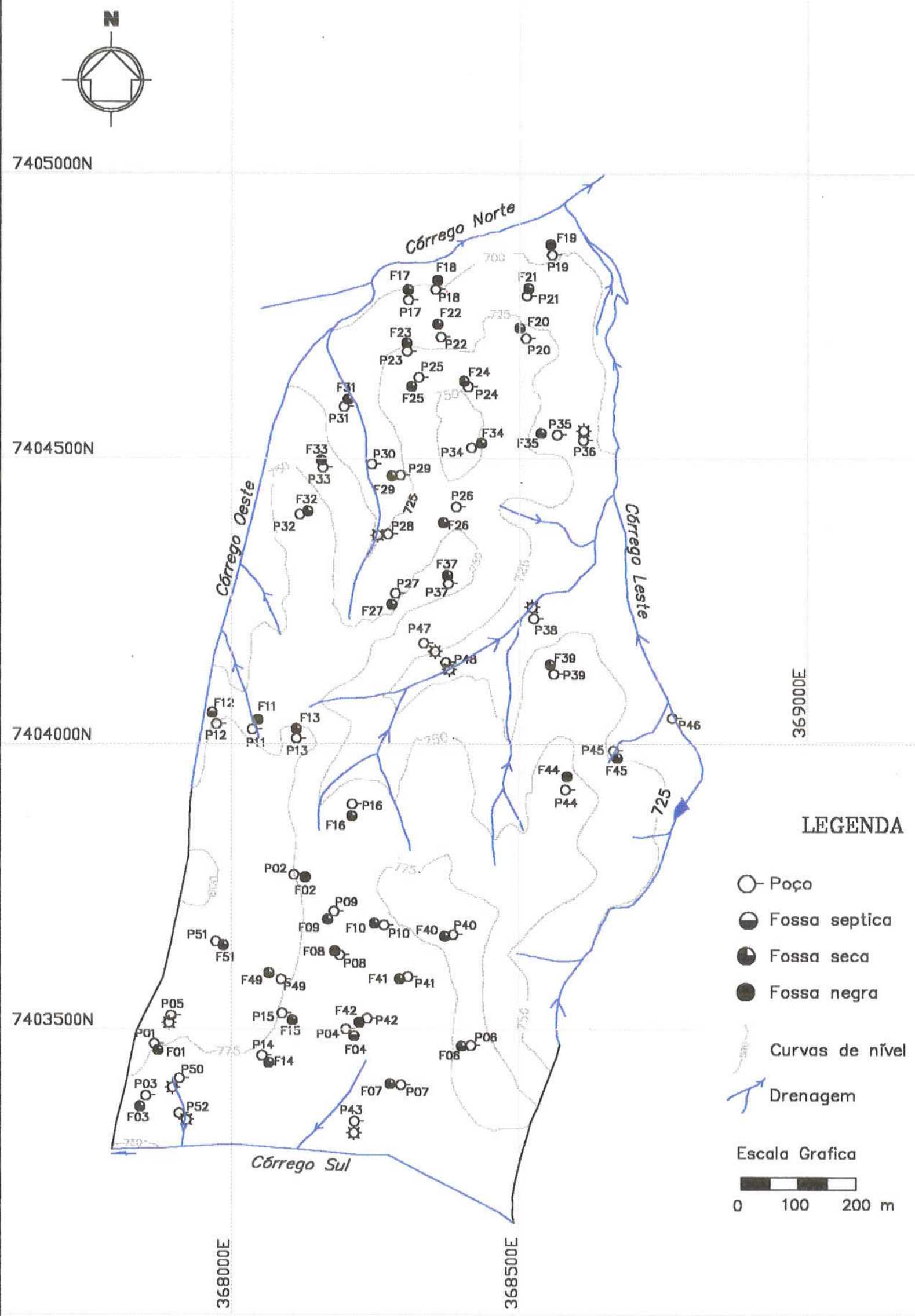

Figura 5.1 - POÇOS E FOSSAS CADASTRADAS NO BAIRRO RECANTO MÔNICA 


\subsection{Características potenciométricas locais}

A Tabela $\mathbf{5 . 1}$ apresenta a profundidade dos poços cadastrados e a profundidade do nível d'água avaliada durante a fase de cadastramento, no início desta pesquisa. A cota dos poços foi obtida a partir do mapa topográfico (escala 1:5.000) da Prefeitura Municipal de Itaquaquecetuba. Com isso, foi possivel calcular a carga hidráulica de cada de poço em relação ao nivel do mar.

Como referido no item 4.2, a partir do valor da carga hidráulica dos poços, foram interpoladas curvas equipotenciais, resultando no mapa potenciométrico, mostrado em planta na Figura 5.2. Supondo o aqüífero homogêneo e isotrópico, o fluxo da água subterrânea (setas azuis do mapa) é aproximadamente perpendicular às linhas equipotenciais. O sentido de movimento da água subterrânea ocorre do maior para o menor potencial hidráulico.

O mapa potenciométrico mostra que as maiores cargas hidráulicas estão localizadas na região sul do bairro, coincidindo com as maiores elevações topográficas. Na região norte, porém, o gradiente hidráulico é maior, refletindo uma seqüência de vales e morros em relevo acidentado.

Na região sul, em direção paralela e próxima aos poços 02 e 40, ocorre um divisor de água local, sendo que a sul deste divisor ocorrem 02 sentidos distintos de fluxo da água subterrânea:

(a) fluxo de sentido SE, entre P02 $\rightarrow$ P08, P51 $\rightarrow$ P04 e P05 $\rightarrow$ P14;

(b) fluxo de sentido SW, entre $\mathrm{P} 40 \rightarrow \mathrm{P} 42$ e P06 $\rightarrow$ P43.

Estes 02 sentidos de fluxo da água subterrânea coincidem de forma aproximada com o gradiente topográfico do relevo daquela região.

As elevadas cargas hidráulicas da região sul do bairro Recanto Mônica se projetam na região norte na direção NNE, alinhada de maneira aproximada com os poços $13,27,37,26$ e 34 . 
Tabela 5.1 - Características hidráulicas dos poços cadastrados

\begin{tabular}{|c|c|c|c|c|}
\hline Poço & Profundidade $(\mathrm{m})$ & Nível d'água (m) & $\operatorname{Cota}(m)$ & Carga Hidráulica $(m)$ \\
\hline PO1 & 8,0 & 6,0 & 780,0 & 774,0 \\
\hline $\mathrm{PO} 2$ & 9,5 & 7,8 & 775,0 & 767,2 \\
\hline $\mathrm{PO} 3$ & 18,0 & 16,6 & 770,0 & 753,4 \\
\hline PO4 & 2,0 & 0,5 & 760,0 & 759,5 \\
\hline P05 & 13,0 & 10,0 & 787,0 & 777,0 \\
\hline P06 & 22,0 & 19,2 & 780,0 & 760,8 \\
\hline P07 & 6,0 & 4,7 & 763,0 & 758,3 \\
\hline P 08 & 3,0 & 1,6 & 764,0 & 762,4 \\
\hline P09 & 3,5 & 1,3 & 766,0 & 764,7 \\
\hline$P 10$ & 8,0 & 6,4 & 772,0 & 765,6 \\
\hline P 11 & 6,0 & 4,7 & 765,0 & 760,3 \\
\hline P 12 & 20,0 & 18,0 & 775,0 & 757,0 \\
\hline$P 13$ & 15,0 & 13,2 & 777,0 & 763,8 \\
\hline P14 & 11,0 & 8,5 & 773,0 & 764,5 \\
\hline$P 15$ & 20,0 & 18,5 & 774,0 & 755,5 \\
\hline$P 16$ & 9,0 & 7,0 & 760,0 & 753,0 \\
\hline P 17 & 4,5 & 2,8 & 706,0 & 703,2 \\
\hline$P 18$ & 6,0 & 2,5 & 702,0 & 699,5 \\
\hline P 19 & 3,5 & 2,5 & 608,0 & 695,5 \\
\hline 1220 & 16,0 & 12,5 & 132,0 & 719,5 \\
\hline P 21 & 8,0 & 5,6 & 713,0 & 707,4 \\
\hline P 22 & 8,0 & 7,0 & 720,0 & 713,0 \\
\hline P 23 & 16,0 & 12,5 & 727,0 & 714,5 \\
\hline P24 & 20,0 & 18,5 & 745,0 & 726,5 \\
\hline P 25 & 16,0 & 15,0 & 738,0 & 723,0 \\
\hline P 26 & 21,0 & 20,1 & 747,0 & 726,9 \\
\hline P 27 & 14,0 & 13,8 & 748,0 & 734,2 \\
\hline P 28 & 9,0 & 5,0 & 728,0 & 723,0 \\
\hline P29 & 8,0 & 3,2 & 721,0 & 717,8 \\
\hline P 30 & 5,0 & 2,0 & 717,0 & 715,0 \\
\hline P 31 & 6,0 & 2,3 & 714,0 & 711,7 \\
\hline P 32 & 31,0 & 30,0 & 756,0 & 726,0 \\
\hline P 33 & 22,0 & 20,0 & 735,0 & 715,0 \\
\hline P 34 & 13,0 & 12,0 & 752,0 & 740,0 \\
\hline P 35 & 1,5 & 0,1 & 714,0 & 713,9 \\
\hline P 36 & 6,0 & 4,5 & 708,0 & 703,5 \\
\hline P 37 & 17,0 & 15,7 & 752,0 & 736,3 \\
\hline P 38 & 8,0 & 3,7 & 711,0 & 707,3 \\
\hline P 39 & 17,0 & 14,4 & 735,0 & 720,6 \\
\hline P 40 & 21,0 & 19,5 & 780,0 & 760,5 \\
\hline P41 & 14,0 & 11,3 & 770,0 & 758,7 \\
\hline P 42 & 8,0 & 4,0 & 761,0 & 757,0 \\
\hline P 43 & 2,0 & 0,8 & 757,0 & 756,2 \\
\hline P 44 & 17,0 & 14,0 & 758,0 & 744,0 \\
\hline P 45 & 2,5 & 0,3 & 723,0 & 722,7 \\
\hline P 46 & 3,0 & 1,8 & 713,0 & 711,2 \\
\hline P 47 & 15,0 & 11,8 & 730,0 & 718,2 \\
\hline P 48 & 8,0 & 3,9 & 715,0 & 711,1 \\
\hline P 49 & 20,0 & 18,8 & 779,0 & 760,2 \\
\hline P 50 & 4,0 & 2,2 & 764,0 & 761,8 \\
\hline P 51 & 25,0 & 19,0 & 796,0 & 777,0 \\
\hline P 52 & 5,0 & 3,6 & 758,0 & 754,4 \\
\hline
\end{tabular}


N

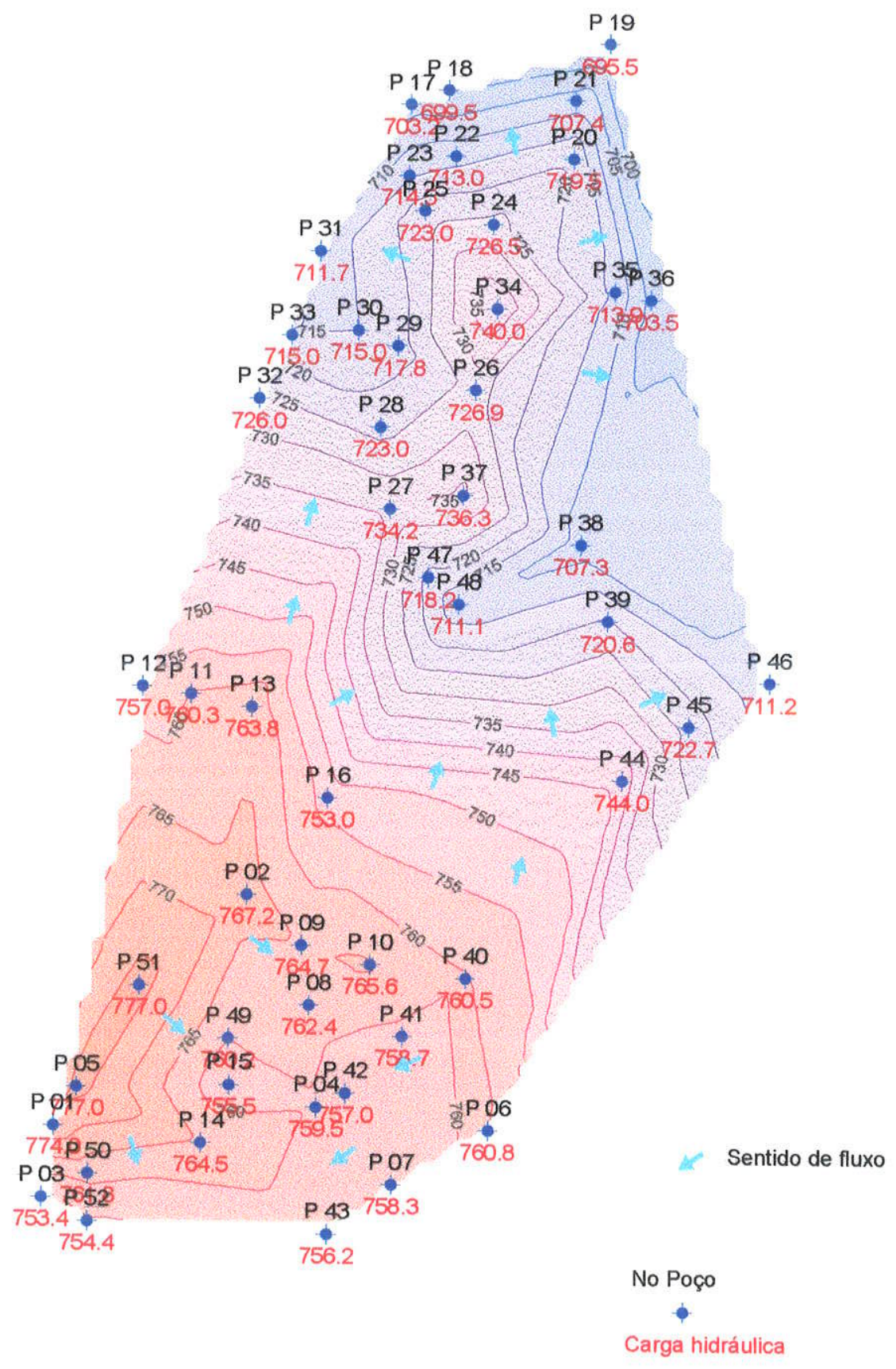

Figura 5.2 - Mapa potenciométrico 
Os poços 34 e 37 possuem as maiores cargas hidráulicas desta região Entre os poços 34 e 37, a oeste, o fluxo da água subterrânea é convergente, da mesma forma que ocorre entre os poços 37 e 44. Este padrão de fluxo está relacionado aos vales topográficos que ocorrem naquelas regiões.

As linhas de fluxo entre P34 $\rightarrow$ P31, P34 $\rightarrow$ P18, P34 $\rightarrow$ P19, P34 $\rightarrow$ P36, apresentam padrões divergentes de fluxo, da mesma forma que entre P44 $\rightarrow$ $\mathrm{P} 46$ e P44 $\rightarrow$ P39, refletindo as características locais do relevo.

\subsection{Características geológicas locais}

Na região do bairro Recanto Mônica, quase inexistem afloramentos de rocha sã. Em alguns cortes de estrada, é visível o bandamento gnáissico da rocha alterada conferido pela cor contrastante dos minerais de alteração (bandas claras e escuras).

Alguns pequenos e dispersos blocos de gnaisse ocorrem no bairro, com minerais de granulação fina a média, constituídos por quartzo $(30 \%)$, plagioclásio (25\%), feldspato potássico (40\%) e biotita $(05 \%)$. O bandamento da rocha é milimétrico, predominantemente.

Em relação aos aspectos estruturais, a rocha apresenta pronunciada foliação gnáissica, de direção N63E a N81E e mergulho médio de $59,5^{\circ}$. O plano de foliação contém lineações de estiramento mineral e dobras intrafoliais. Pelo menos dois sistemas de fraturas são evidentes, sendo um principal. A Tabela $\mathbf{5 . 2}$ resume os dados estruturais coletados em campo.

Para caracterizar o manto de alteração de rocha local, foram executadas 06 sondagens a trado em 02 vertentes topográficas distintas, como descrito no item 4.5. Três sondagens foram executadas na região norte do bairro, ao lado dos poços 21-20-19: (S21, S20 e S19). O outro grupo de sondagens foi executado ao lado dos poços 51-49-04 (\$51, S49 e S04).

A profundidade de investigação foi até o nível d'água local, início da zona saturada do solo. A Figura $\mathbf{5 . 3}$ apresenta 02 seções geológicas esquemáticas, construídas a partir dos dados de sondagem. 
Tabela 5.2 - Dados geológico-estruturais medidos em campo

\begin{tabular}{|c|c|}
\hline Elemento estrutural & Posicionamento espacial \\
\hline Foliação principal (bandamento gnáissico) & $\begin{array}{l}\text { N70E/72NW, N81E/67NW, N63E/8ONW, N75E/84NW, } \\
\text { N72E/8ONW, N63E/45NW, N75E/59NW, N77E/42NW, } \\
\text { N71E/41NW, N68E/54NW, N71E/3ONW }\end{array}$ \\
\hline Lineação de estiramento mineral & $\begin{array}{l}S 82 W / 22^{\circ}, S 84 W / 28^{\circ}, \text { OESTE } / 17^{\circ}, N 87 W / 24^{\circ}, \\
S 79 W / 23^{\circ}\end{array}$ \\
\hline Sistema de fratura principal* & N07E/55SE, N35W/84NE, N26W/86NE \\
\hline Sistema de fratura secundário** & NO4E/74NW, N15W/55NE \\
\hline
\end{tabular}

* a densidade de fraturas é de aproximadamente $1,5 \mathrm{~m}$; o rejeito máximo observado é de $1 \mathrm{~cm}$; há preenchimento de quartzo e óxido de manganês

$\times \times$ maior densidade de fraturas, quando presente $(1 \mathrm{~cm})$ 

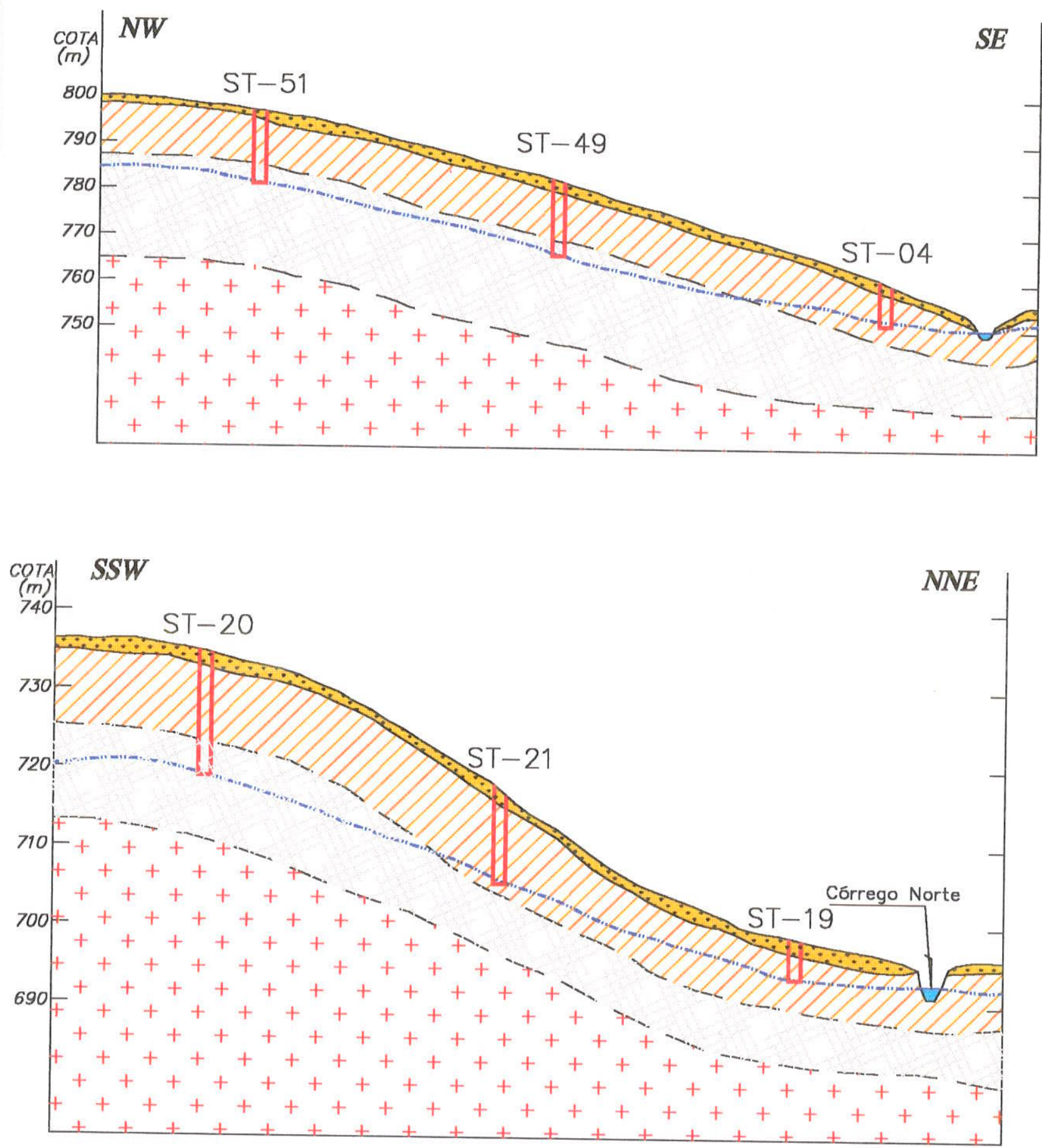

Solo silto-argiloso, com pouca areia fina, castonho, corn matéria orgânica

Rocha alterada constituida por material siltoso, com argila
e areia fina, presença de minerais residuais guartzo, feldspato alterado e pouca bjotita), vermelho -arroxeodo, estrutura residual da rocha (bandada)

Solo argilo-siltoso, com pouca areia fino vermelho, estrutura maciça

++ Rocha sô (em posiçש̃o inferida)

ST-19 Sondagem a Trado

- Nivel do lençol freático

Figura 5.3 - SEÇÕES GEOLÓGICAS ESQUEMÁTICAS 
Foram definidas 03 unidades geológicas distintas, a partir dos dados de sondagem (do topo para a base):

(a) Solo superficial silto-argiloso, com pouca areia fina, castanho, com matéria orgânica e restos vegetais (raízes);

(b) Solo argilo-siltoso, com pouca areia fina, vermelho e com estrutura maciça;

(c) Rocha alterada (alterita) constituída por material siltoso com argila e areia fina, presença de minerais residuais (quartzo, feldspato alterado e pouća biotita), vermelho-arroxeado, com estrutura residual da rocha original (bandada).

Próximo ao nível d'água, foi evidenciado solo saturado com evidência de contaminação fecal, com forte odor e coloração cinza-esverdeada, principalmente nas sondagens de posição jusante (S19 e S04).

\subsection{Resistividade do solo}

De acordo com os procedimentos relatados no item 4.4, foram realizadas 06 sondagens elétricas verticais (SEVS) no bairro Recanto Mônica. O posicionamento das SEVS é mostrado na Figura 5.4. Os resultados, processados pelo programa RESIST ${ }^{\mathrm{M}}$ encontram-se no Anexo A.

A Tabela $\mathbf{5 . 3}$ sintetiza os resultados obtidos e mostra para cada SEV O número de camadas com propriedades geofísicas distintas, suas espessuras e os valores de resistividade elétrica. Para cada camada, foi associada uma interpretação geológica correspondente.

Usualmente, num perfil geofísico idealizado, há 03 camadas com resistividades elétricas contrastantes. A primeira está relacionada à zona não saturada do solo, que apresenta, em geral, elevados valores de resistividade elétrica. A segunda camada corresponde à zona saturada, com valores relativamente baixos de resistividade elétrica devido à água que preenche os poros intergranulares. A terceira camada corresponde ao substrato rochoso, identificado pelo aumento da resistividade elétrica em relação à camada sobrejacente. 


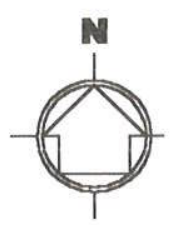

$7405000 \mathrm{~N}$

$7404500 \mathrm{~N}$

$7404000 \mathrm{~N}$

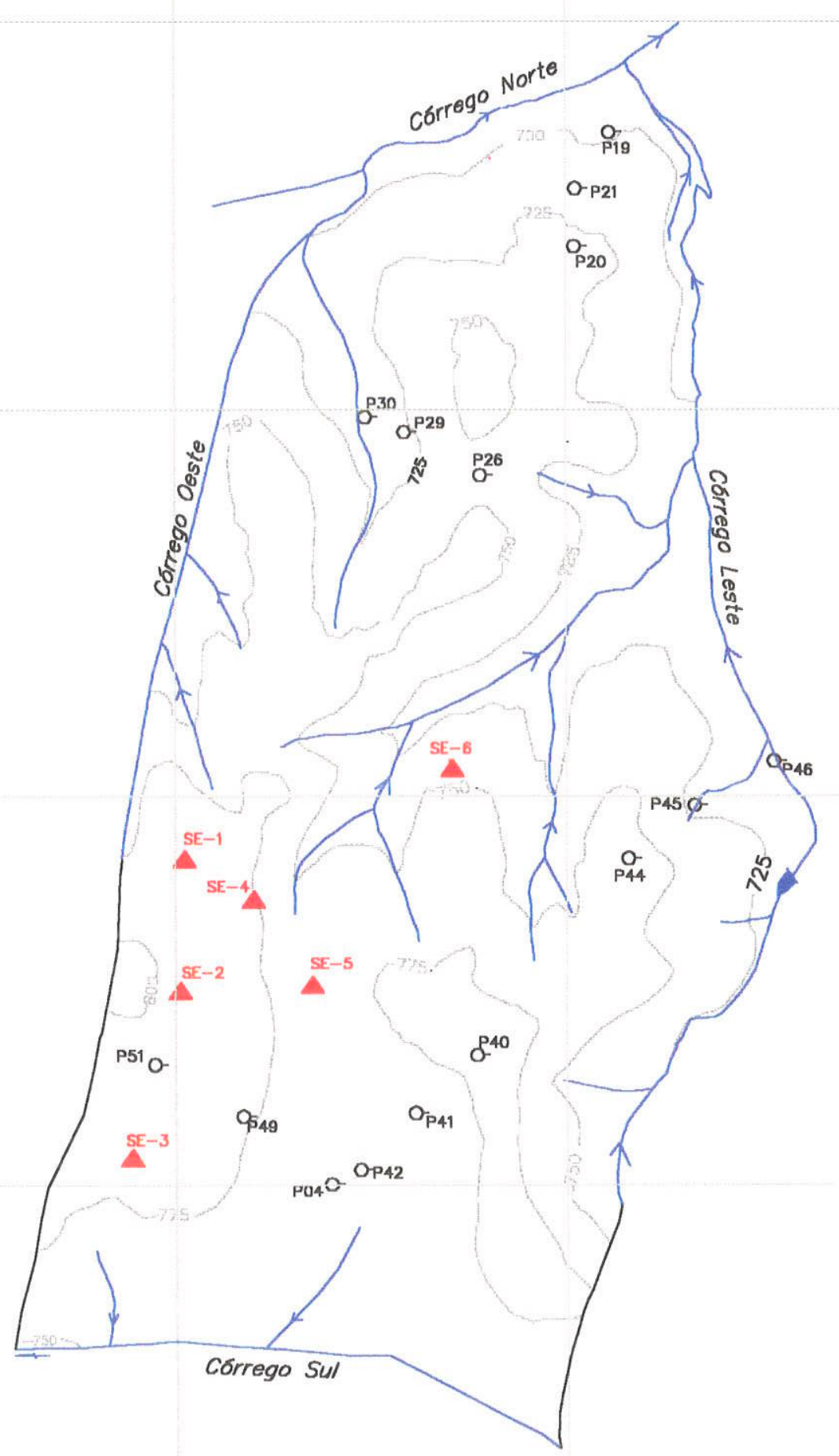

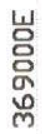

LEGENDA

$7403500 \mathrm{~N}$

능
음
0
m

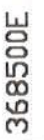

Figura 5.4 - POSICIONAMENTO DAS SONDAGENS ELETRICAS VERTICAIS

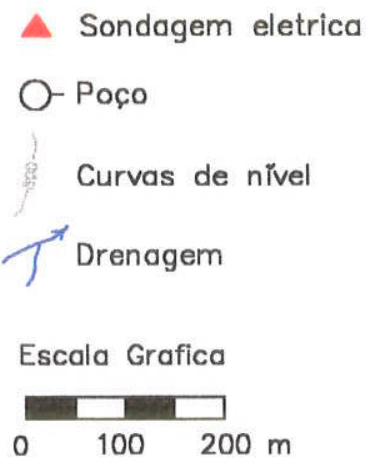


Tabela 5.3 - Síntese dos resultados da investigação geofísica

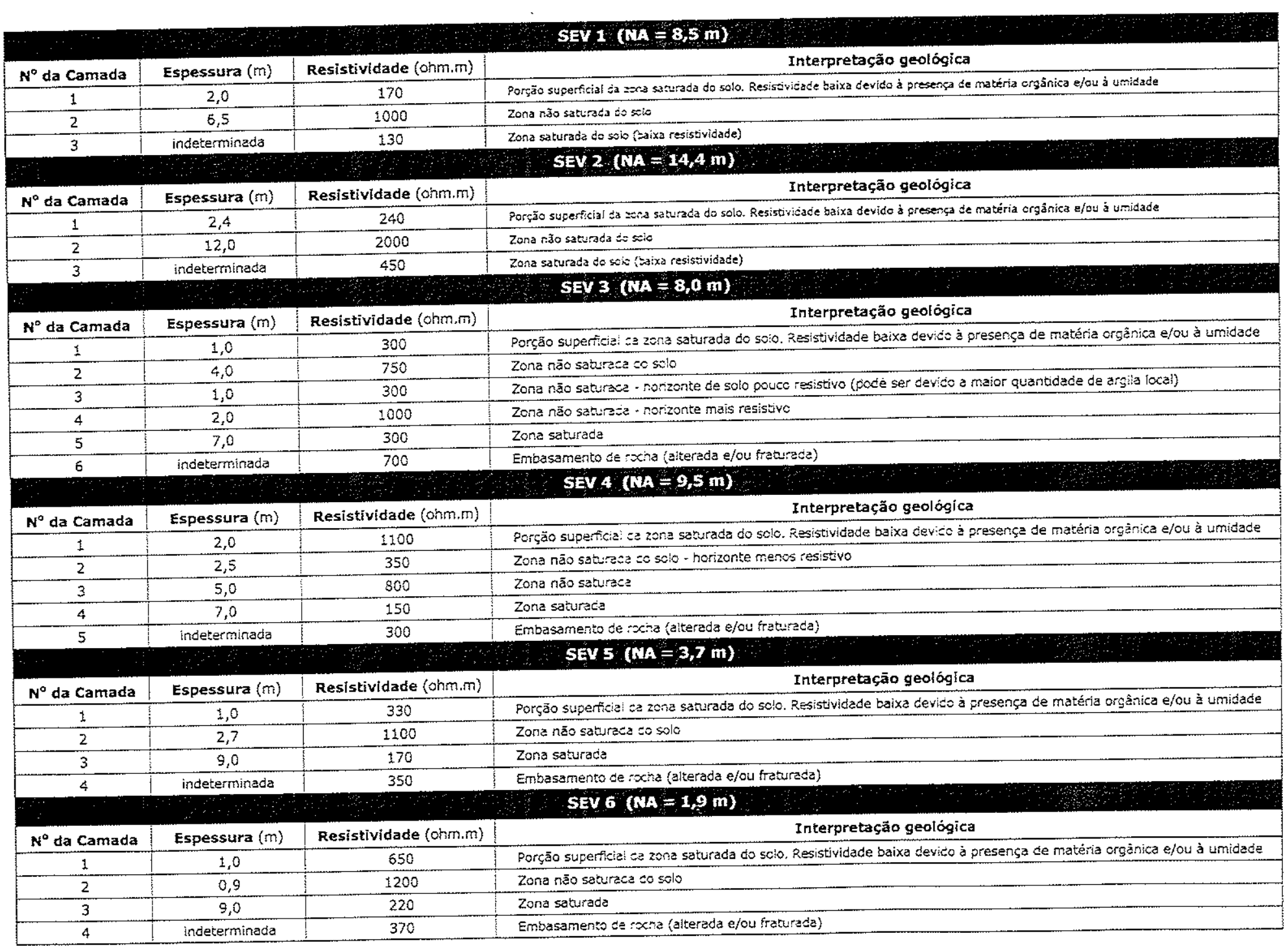

$S E V=$ soncagem etérica vertical

$N A=$ nivet ớgua 
Em perfis geológicos reais, o número de camadas com resistividades elétricas contrastantes é quase sempre maior que três. Das regiões descritas no perfil geológico ideal, a primeira (zona não saturada) é a que mais apresenta variações das propriedades geofísicas, em função dos diferentes horizontes de solo que podem existir no perfil.

Os resultados apresentados na Tabela $\mathbf{5 . 3}$ permitiram identificar 03 unidades hidrogeológicas com resistividades elétricas distintas em função da profundidade.

A zona não saturada do solo variou de 1,9 m (SEV 6) a 14,4 m (SEV 2) de espessura, com propriedades geofísicas distintas.

A camada mais superficial, variando de $1,0 \mathrm{~m}$ (SEVs 3,5 e 6) a $2,4 \mathrm{~m}$ (SEV 2) apresentou resistividades menores, de 170 ohm.m (SEV 1) a 650 ohm.m (SEV 6), com exceção da SEV 4 (1100 ohm.m). Os valores de resistividade mais baixos desta camada devem estar associados à unidade superficial do solo e/ou ao conteúdo de matéria orgânica, usualmente maiores no primeiro metro de solo.

As SEVs 1, 2, 5 e 6 apresentaram uma segunda camada de solo não saturado em água com elevada resistividade elétrica, de 1000 a 2000 ohm.m. Nas SEVS 3 e 4, a unidade não saturada inferior do solo mostrou-se heterogênea, subdividida em 02 ou 03 camadas com resistividades elétricas distintas, variando de 300 a 1000 ohm.m. A existência de camadas com propriedades geofísicas distintas deve estar relacionada a granulação do solo residual de alteração - horizontes mais arenosos conferem resistividade elétrica maior ao solo, ao contrário dos horizontes argilosos que retém mais água na sua estrutura. Solos derivados de gnaisses parcialmente migmatizados possuem variações de granulação em diferentes escalas (milimétricas a métricas)

A zona saturada do solo é facilmente detectada no perfil geofísico devido à diminuição brusca do valor da resistividade elétrica a partir de determinada profundidade (nivel d'ágụa). Os valores de resistividade elétrica desta unidade variaram de 130 a 450 ohm.m. 
O substrato rochoso do aqǘfero freático possui maior resistividade elétrica que a unidade saturada sobrejacente (solo). Os valores, entretanto, são bastante variados, dependendo do grau de alteração da rocha e do grau de fraturamento. Quanto maior o fraturamento e/ou grau de alteração da rocha, maior será a quantidade de água na massa rochosa e, por conseqüência, menor será sua resistividade elétrica.

Nas SEVS 3, 4, 5 e 6, a resistividade elétrica associada ao embasamento variou de 300 a 700 ohm.m, pouco superior à unidade saturada sobrejacente, indicando que o substrato rochoso local apresenta-se alterado e/ou fraturado, com expressiva quantidade de água intersticial.

\subsection{Permeabilidade do solo}

Os dados dos ensaios de permeabilidade em solo, discutidos no item 4.6, são apresentados na Tabela 5.4, juntamente com os parâmetros de cálculo e os resultados obtidos.

Os valores de rebaixamento do nível d'água (nível dinâmico) em função do tempo são apresentados graficamente na Figura 5.5. A localização dos pontos investigados é mostrada na Figura 4.6 (item 4.6).

A condutividade hidráulica $(K)$ calculada é da ordem de $10^{-4} \mathrm{~cm} / \mathrm{s}$, variando de $1,1 \times 10^{-4}$ a $2,0 \times 10^{-4} \mathrm{~cm} / \mathrm{s}$. Estes resultados correspondem à permeabilidade do solo não saturado até 02 metros de profundidade (seção investigada), cujos valores são relativamente homogêneos. Geologicamente, correspondem a materiais siltosos, silto-arenosos, areno-siltosos ou argiloarenosos (Fetter, 1994), como aqueles determinados em campo a partir das sondagens realizadas.

\subsection{Velocidade média da água subterrânea}

O cálculo da velocidade média da água subterrânea local é apresentado na Tabela 5.5. A velocidade média foi calculada para cada vertente investigada, a partir dos valores de $\mathrm{K}$ determinados e do gradiente hidráulico entre 02 poços alinhados na mesma vertente topográfica. 
Tabela 5.4 - Ensaios de Permeabilidade em Solo

Modalidade: Rebaixamento acima do nível d'água (carga variável) (ABGE, 1955)

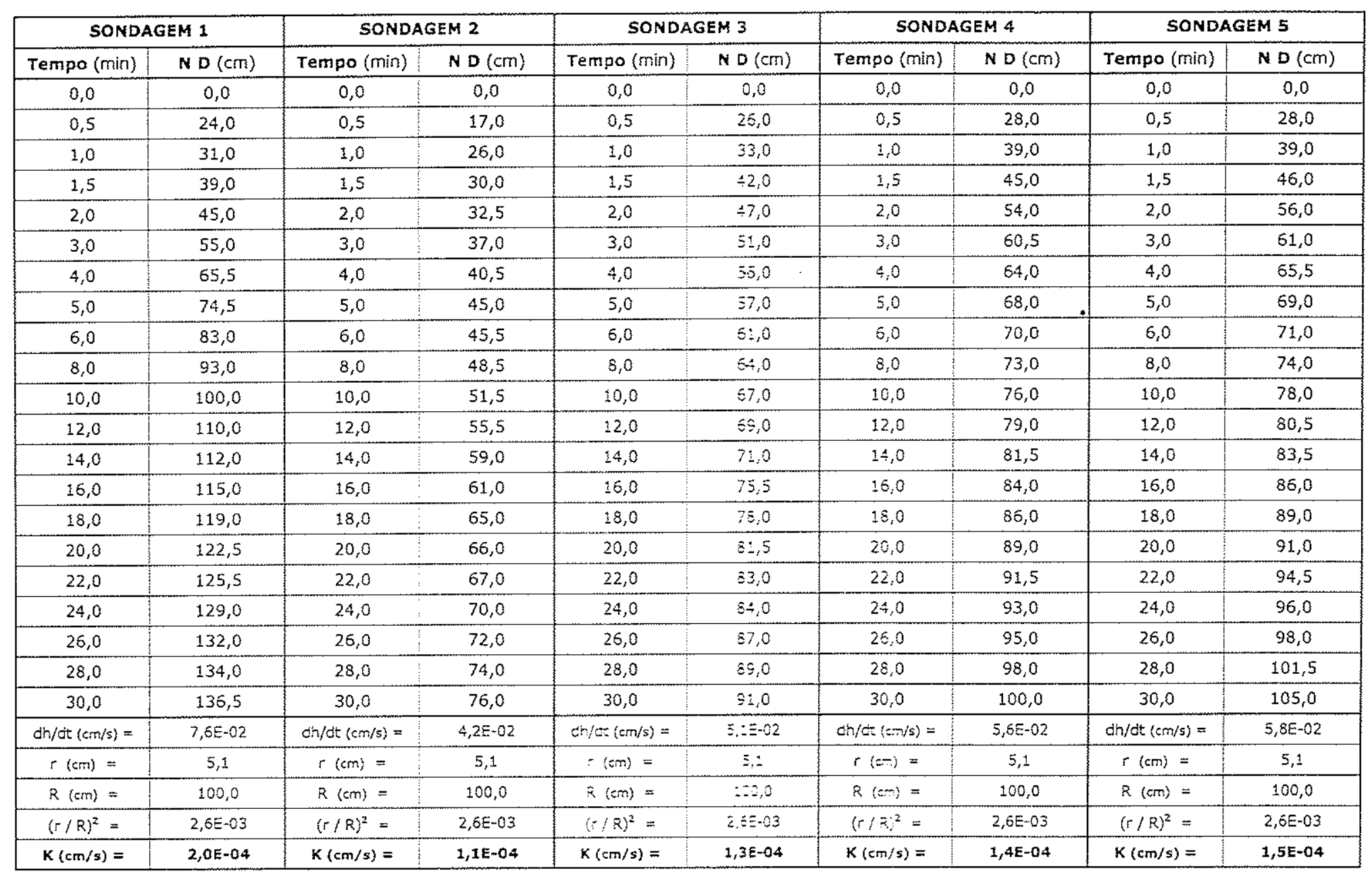

onde: $N O=$ nivel $\epsilon^{\prime}$ água dinămico $\mathrm{dh}=$ rebaixamento

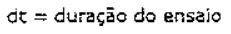

$R^{2}+R-h=0$ (em mecros)

$m=$ protudidade do $4 \mathrm{r}_{0}=2 \mathrm{~m}$ $t=$ reio do furo

$\mathrm{K}=$ condutividaèe h:dráulica

$K=(d h / d t) \cdot(r / R)^{2}$ 

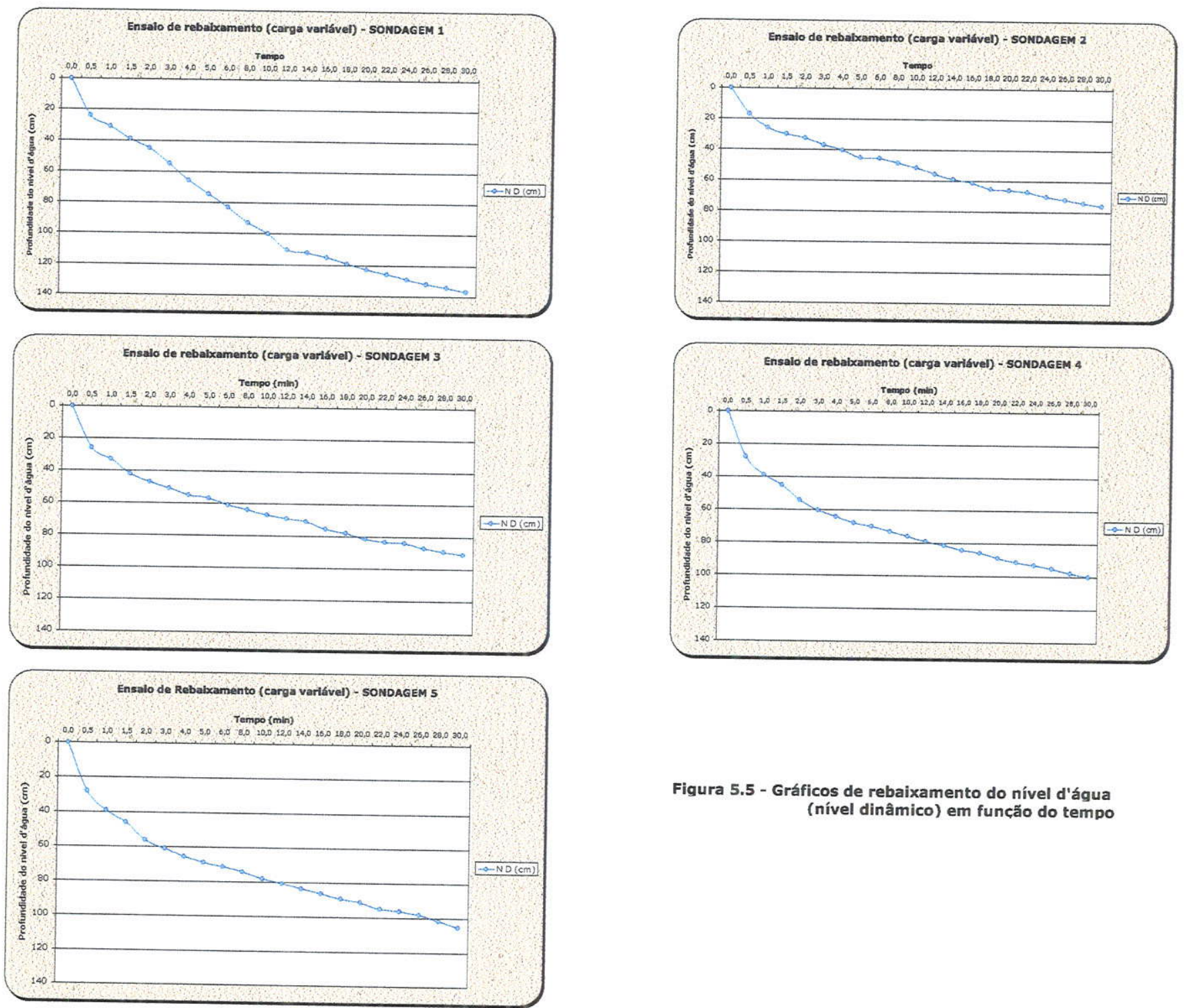

Figura 5.5 - Gráficos de rebaixamento do nível d'água (nível dinâmico) em funcăo do tempo 


\section{Tabela 5.5 - Cálculo da velocỉdade média da água subterrânea nas 05 vertentes estudadas}

\begin{tabular}{|c|c|c|c|c|c|c|c|c|}
\hline Sondagem & Poços & $\mathrm{dH}(\mathrm{m})$ & $\mathbf{d x}(\mathrm{m})$ & $\mathbf{i}$ & $\mathrm{K}(\mathrm{cm} / \mathrm{s})$ & ne & $v(\mathrm{~cm} / \mathrm{s})$ & $\mathbf{v}(\mathrm{m} / \mathrm{ano})$ \\
\hline$K_{1}$ & P 51 - P 04 & 17,5 & 300 & 0,058 & $2,0 E-04$ & \multirow{5}{*}{0,15} & $7,8 E-05$ & 24,5 \\
\hline $\mathrm{K} 2$ & $P 20-P 19$ & 24,0 & 170 & 0,141 & $1,1 E-04$ & & $1,0 E-04$ & 32,6 \\
\hline K3 & $P 26-P 30$ & 11,9 & 180 & 0,066 & $1,3 E-04$ & & $5,7 E-05$ & 18,1 \\
\hline K 4 & P $44-P 46$ & 32,8 & 250 & 0,131 & $1,4 \mathrm{E}-04$ & & $1,2 E-04$ & 38,6 \\
\hline K 5 & $P 40-P 42$ & 7,5 & 230 & 0,033 & $1,5 E-04$ & & $3,3 E-05$ & 10,3 \\
\hline
\end{tabular}

onde: $d H=$ diferença entre cargas hidráulicas [L]

$\mathrm{dx}=$ distância horizontal $[\mathrm{L}]$

$i=$ gradiente hidráulico (adimensional)

$K=$ condutividade hidráulica $[L] \cdot[T]^{-1}$

$n_{e}=$ porosidade efetiva (adimensional)

$v=$ velocidade média $[\mathrm{L}] \cdot[\mathrm{T}]-1$ $v=-k \cdot i / n_{e}$

onde: $\mathbf{i}=\mathbf{d} \mathbf{H} / \mathbf{d x}$

(o sinal negativo indica o sentido da água subterrânea do maior para o menor potencial hidráulico) 
A velocidade média é diretamente proporcional à condutividade hidráulica e ao gradiente hidráulico. Cabe salientar que a condutividade hidráulica calculada no item 5.5 corresponde à seção do solo até 02 metros de profundidade. Entretanto, para efeito de cálculos hidrodinâmicos, foi considerado que o aqüífero freático estudado seja considerado homogêneo e isotrópico em toda sua extensão.

Como os valores de $K$ calculados são próximos, a variação das velocidades médias ocorreu de maneira mais significativa em função do gradiente hidráulico nas vertentes investigadas. O gradiente hidráulico é diretamente proporcional à diferença de carga hidráulica entre 02 poços (na mesma linha de fluxo) e inversamente proporcional à distância entre eles.

A velocidade média da água subterrânea local variou de 10,3 (vertente dos poços 40-41-42) a 38,6 m/ano (vertente dos poços 20-21-19), com valor médio aproximado de $\mathbf{2 5} \mathrm{m} /$ ano.

\subsection{Análises laboratoriais e discussão dos resultados}

A abordagem interpretativa dos resultados laboratoriais foi feita em função do tempo (período monitorado) com relação a 03 aspectos principais:

(a) Sazonalidade, que está relacionada à variação climática ao longo do ano hidrológico monitorado;

(b) Posicionamento de poços numa mesma vertente, envolvendo 01 poço montante, 01 poço intermediário e 01 poço jusante em relação às vertentes determinadas;

(c) Comparação dos resultados entre as 05 vertentes definidas, relacionando os aspectos sanitários e a densidade populacional nas diferentes regiões do bairro Recanto Mônica.

\subsubsection{Análises microbiológicas}

Os resultados das análises de coliformes fecais e coliformes totais, realizadas durante 01 ano hidrológico nos 15 poços previamente selecionados, são apresentados na Tabela 5.6. Os resultados que evidenciaram a presença de coliformes fecais estão em destaque naquela tabela. 
Tabela 5.6 - Resultados analíticos de coliformes fecais e totais dos 15 poços monitorados - 01 ano hidrológico (NMP/100mL)

\begin{tabular}{|c|c|c|c|c|c|c|c|c|c|c|c|c|c|c|c|c|c|c|c|c|c|}
\hline \multirow{2}{*}{ Poşo } & \multirow{2}{*}{ Posição } & \multicolumn{2}{|c|}{20.08 .1997} & \multicolumn{2}{|c|}{16.09 .1997} & \multicolumn{2}{|c|}{27.10 .1997} & \multicolumn{2}{|c|}{09.02 .1998} & \multicolumn{2}{|c|}{02.03 .1998} & \multicolumn{2}{|c|}{23.03 .1998} & \multicolumn{2}{|c|}{16.04 .1998} & \multicolumn{2}{|c|}{08.05 .1998} & \multicolumn{2}{|c|}{17.06 .1998} & \multicolumn{2}{|c|}{21.07 .1998} \\
\hline & & CF & CT & CF & ст & CF & ст & CF & Cт & CF & ст & CF & ст & CF & ст & CF & ст & CF & ст & CF & ст \\
\hline P 20 & montante & nd & 130 & nd & 1600 & nd & 170 & $>1600$ & $>1600$ & 4 & $>1600$ & nd & $>1600$ & nd & 500 & 4 & 1600 & nd & 900 & nd & 1600 \\
\hline P 21 & intermediária & 23 & 23 & nd & 30 & nd & 30 & $>1600$ & $>1600$ & 220 & $>1600$ & 300 & $>1600$ & 7 & 300 & nd & 300 & nd & 70 & nd & nd \\
\hline P 19 & jusante & 2 & 50 & 17 & 500 & 30 & 1600 & $>1600$ & $>1600$ & 900 & $>1600$ & $>1600$ & $>1600$ & 900 & 1600 & 170 & $>1600$ & nd & 110 & 2 & 80 \\
\hline P 44 & montante & 4 & $>1600$ & 13 & 500 & 220 & 1600 & $>1600$ & $>1600$ & $>1600$ & $>1600$ & 1600 & $>1600$ & 300 & 1600 & 130 & $>1600$ & 110 & $>1600$ & $>1600$ & $>1600$ \\
\hline P 45 & intermediária & 240 & 300 & 140 & 1600 & 500 & 900 & 500 & 900 & 50 & $>1600$ & 1600 & $>1600$ & 4 & 900 & 80 & 900 & 2 & 500 & 13 & 500 \\
\hline P 46 & jusante & nd & 4 & nd & 27 & nd & 4 & 4 & 17 & nd & 900 & nd & 900 & nd & 1600 & nd & 300 & nd & 14 & nd & 900 \\
\hline P 40 & montante & 2 & 220 & 2 & 34 & 17 & 500 & 17 & $>1600$ & nd & $>1600$ & 30 & $>1600$ & 2 & $>1600$ & 8 & 1600 & nd & 220 & nd & $>1600$ \\
\hline P 41 & intermediária & nd & 17 & nd & 33 & 900 & 900 & 8 & $>1600$ & nd & $>1600$ & 8 & $>1600$ & nd & 50 & nd & 50 & 2 & 130 & 2 & 4 \\
\hline P 42 & jusante & nd & nd & nd & 4 & nd & nd & 23 & 23 & nd & 23 & nd & 130 & nd & $>1600$ & 2 & 900 & nd & 2 & nd & 4 \\
\hline P 51 & montante & nd & 14 & nd & 7 & nd & 170 & nd & 23 & nd & 17 & nd & 27 & nd & $>1600$ & nd & $>1600$ & nd & 70 & nd & nd \\
\hline P 49 & intermediária & nd & nd & nd & 8 & nd & 220 & 2 & 17 & nd & 4 & 8 & 8 & nd & nd & nd & 50 & nd & 17 & nd & nd \\
\hline P 04 & jusante & nd & nd & nd & nd & nd & 4 & 50 & 4 & 4 & 33 & 11 & 22 & 8 & 50 & 50 & 50 & nd & 2 & nd & 11 \\
\hline P 26 & montante & nd & 50 & nd & 7 & nd & 500 & 13 & $>1600$ & 2 & $>1600$ & nd & 1600 & nd & 130 & 9 & $>1600$ & nd & 80 & nd & 170 \\
\hline P 29 & intermediária & nd & 2 & nd & 8 & 13 & 240 & 130 & $>1600$ & 900 & $>1600$ & 1600 & $>1600$ & $>1600$ & $>1600$ & 22 & 140 & 130 & $>1600$ & 17 & 500 \\
\hline P 30 & jusante & nd & 130 & 22 & 170 & 17 & 240 & nd & nd & 280 & $>1600$ & $>1600$ & $>1600$ & 1600 & $>1600$ & 7 & 300 & 130 & 1600 & 130 & $>1600$ \\
\hline
\end{tabular}


A Figura 5.6 mostra graficamente a concentração de coliformes fecais ao longo do período monitorado. Os resultados mostraram que há grande influência sazonal na qualidade da água subterrânea.

Entre os meses de outubro a abril (primavera e verão), as concentrações de coliformes fecais foram elevadas, chegando a ultrapassar o limite superior da escala quantitativa ( $>1.600 \mathrm{NMP} / 100 \mathrm{~mL}$ ). Naquela época, todos os poços, incluindo os de posição montante (com exceção do P51), apresentaram contaminação fecal.

Nos meses de outono e inverno, a amplitude e magnitude da contaminação foram menores. Naquele período, determinados poços, mesmo em posição de baixada, não apresentaram coliformes fecais nas amostras analisadas em determinados meses, como é o caso dos poços $04,42,46,19$ e 30.

Os resultados das análises de coliformes fecais também mostraram que a qualidade da água subterrânea no bairro Recanto Mônica varia ao longo das vertentes monitoradas.

Este fato é nitidamente observado nos gráficos da Figura $\mathbf{5 . 6}$ entre os poços 26-29-30 / 20-21-19 / 51-49-04. A contaminação fecal aumentou ao longo da vertente, de montante para jusante, em função da existência de fossas sépticas e comuns disseminadas no terreno. Na época de chuvas, a ordem de grandeza do aporte de coliformes fecais chegou a ser de 1.000 vezes ao longo da mesma vertente (poços 26-29-30 / 20-21-19). Esta observação corresponde ao modelo conceitual de contaminação fecal apresentado na Figura $\mathbf{1 . 8 .}$

Cabe ressaltar que na vertente dos poços 44-45-46, o padrão da concentração de coliformes fecais é diferente em relação às demais vertentes. Ao lado do P44, existe uma criação de cavalos, onde há muita matéria fecal no solo, que é lixiviada e deve produzir um percolado contendo alta concentração de microorganismos e íons diversos, como o nitrato e cloreto, como veremos mais adiante. Este ponto monitorado difere de todos os outros, por apresentar, em posição de montante, um alto aporte de contaminantes. 

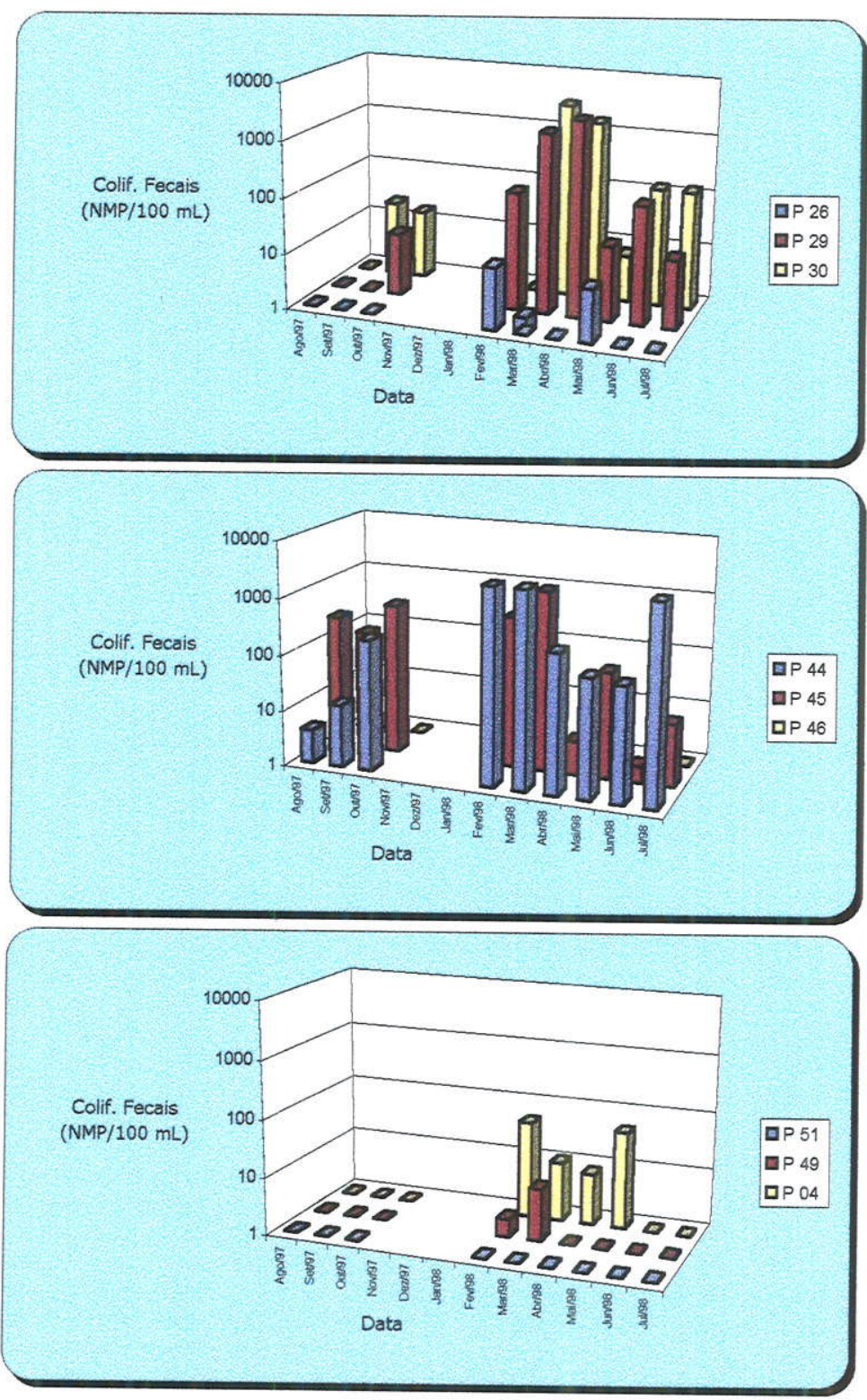
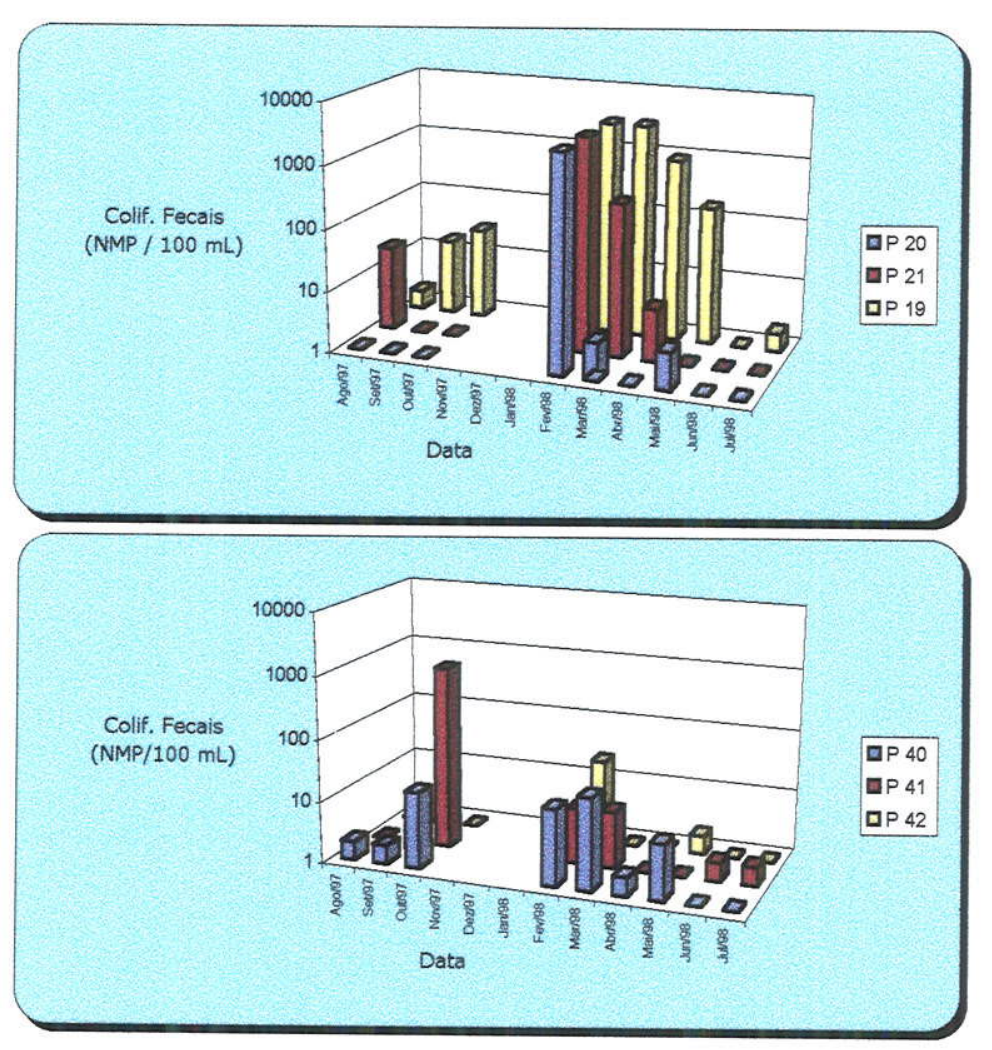

Figura 5.6 - Variação da concentração de coliformes fecais nos poços monitorados 
Os poços que apresentaram maiores índices de contaminação fecal estão localizados na porção norte do bairro Recanto Mônica (P20-P21-P19 / P44P45-P46 / P26-P29-P30). A região norte, apesar de menos povoada (Figura 4.2), é a região mais pobre do bairro, com menos estabelecimentos comerciais, acesso mais difícil em função da declividade e condições de conservação das ruas e evidências mais freqüentes de esgoto a céu aberto.

Como discutido no item 5.1 , menos de 05\% das residências cadastradas possuem fossas sépticas rudimentares, construídas sob critérios próximos aos estabelecidos pela $A B N T$, as quais se localizam na região sul do bairro. A maioria das fossas cadastradas são comuns, mesmo aquelas localizadas na região sul do bairro.

Outra observação feita durante os trabalhos de campo foi que as condições de higiene e limpeza das residências, incluindo a higiene pessoal, são mais precárias na população da região norte. Em muitos casos, o mau cheiro, presença de moscas e doenças foram freqüentemente observadas naquelas residências. Além disso, a água dos poços da região norte era visualmente de menor qualidade, ocorrendo, de forma não excepcional, odores e colorações anômalas.

A contaminação induzida da água subterrânea não deve ser negligenciada. Em 25\% das residências cadastradas, a forma de captação da água é manual, através de balde acoplado em sarilho. Daqueles casos, quase a totalidade foi registrada em residências da região norte. A captação manual oferece maior risco de contaminação induzida, através da manipulação direta da água e do balde exposto na superfície e freqüentemente adicionado no interior do poço.

Entretanto, embora as fossas existentes na região sul também sejam do tipo comum quanto aos aspectos construtivos, observou-se, em geral, um padrão de higiene e limpeza mais satisfatórios naquelas residências, comprovado pela menor concentração de coliformes fecais na água subterrânea naquela região, mesmo no período de maior precipitação pluviométrica (Figura 5.6).

A população da região sul possui um padrão aquisitivo relativamente mais elevado, possuindo estabelecimentos comerciais próprios, como 
padarias, depósitos de construção, lojas, mercados, salões de cabeleireiro, e drogaria. Há também uma escola pública de ensino fundamental e médio, além de um posto de saúde.

A Figura $\mathbf{5 . 7}$ mostra graficamente a concentração de coliformes totais ao longo do período monitorado. Os resultados mostraram que há influência sazonal na ocorrência de coliformes totais, porém menos intensa (menor amplitude) quando comparada aos coliformes fecais.

A magnitude das concentrações de coliformes totais foi maior em relação aos coliformes fecais, muitas vezes ultrapassando o limite superior da escala quantitativa (>1.600 NMP/100 mL), principalmente nos meses de maior precipitação pluviométrica (primavera e verão).

A variação das concentrações de coliformes totais dentro das vertentes monitoradas não foi tão marcante quando comparada à variação de concentração de coliformes fecais. Ao contrário, alguns poços de montante apresentaram concentrações maiores quando comparados aos poços Intermediários ou de jusánte, na mesma vertente topográfica.

Da mesma forma que ocorreu em relação aos coliformes fecais, a concentração de coliformes totais no poço 44 foi anômala, mantendo-se elevada em todos os meses monitorados, independente da época do ano, cujos motivos foram aqueles já discutidos.

Em relação à qualidade da água subterrânea nas diferentes regiões do bairro Recanto Mônica, os poços monitorados na região sul apresentaram concentrações um pouco menores de coliformes totais, evidenciada principalmente na vertente dos poços 51-49-04. Na vertente dos poços 40-4142, a diferença foi pequena em relação aos poços monitorados na região norte.

A Tabela $\mathbf{5 . 7}$ mostra os resultados das análises de colifagos, relacionadas à água dos 15 poços rasos monitorados durante o ano hidrológico. Na Figura 5.8, os resultados obtidos são mostrados graficamente em função do tempo para cada vertente investigada. 

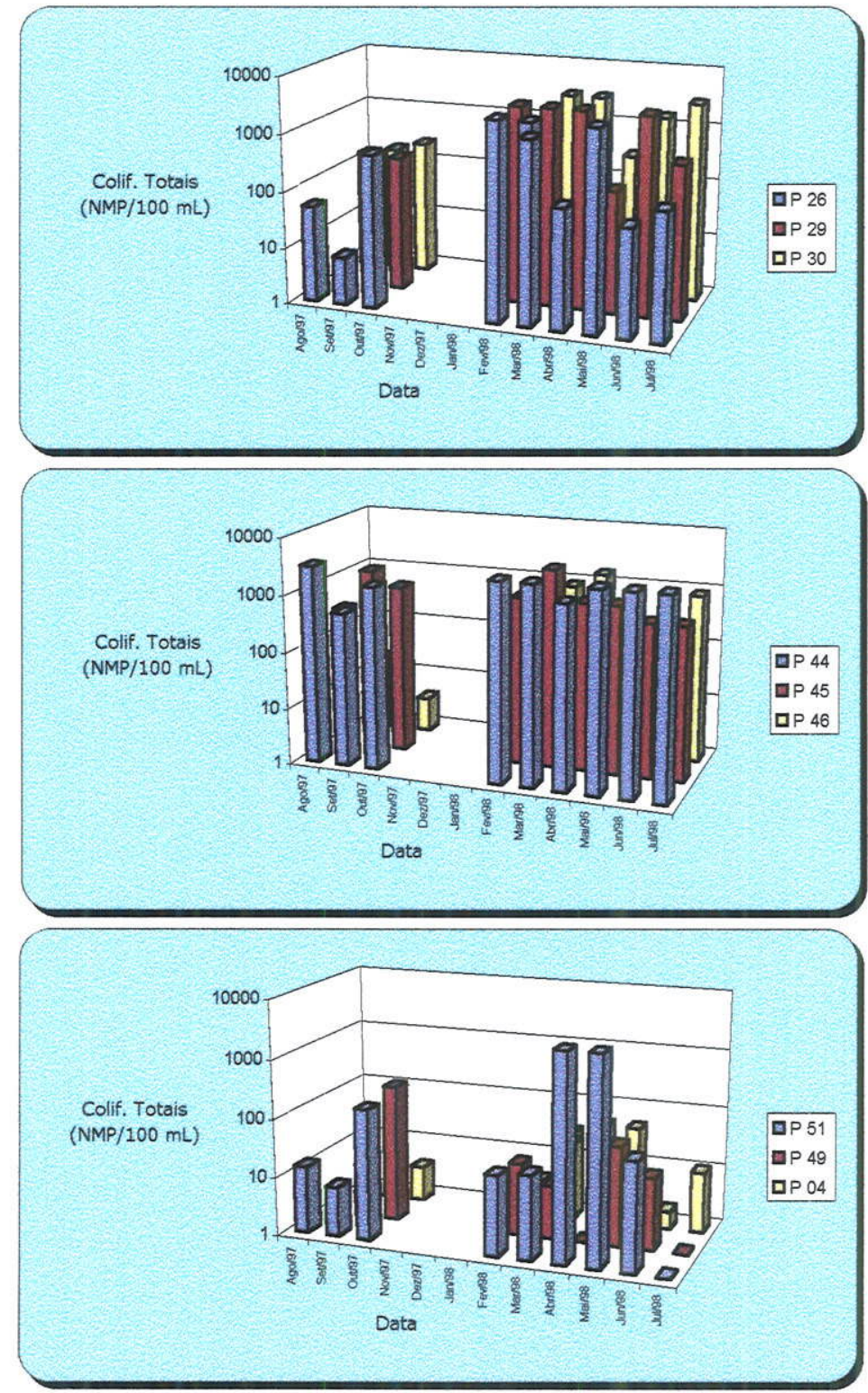
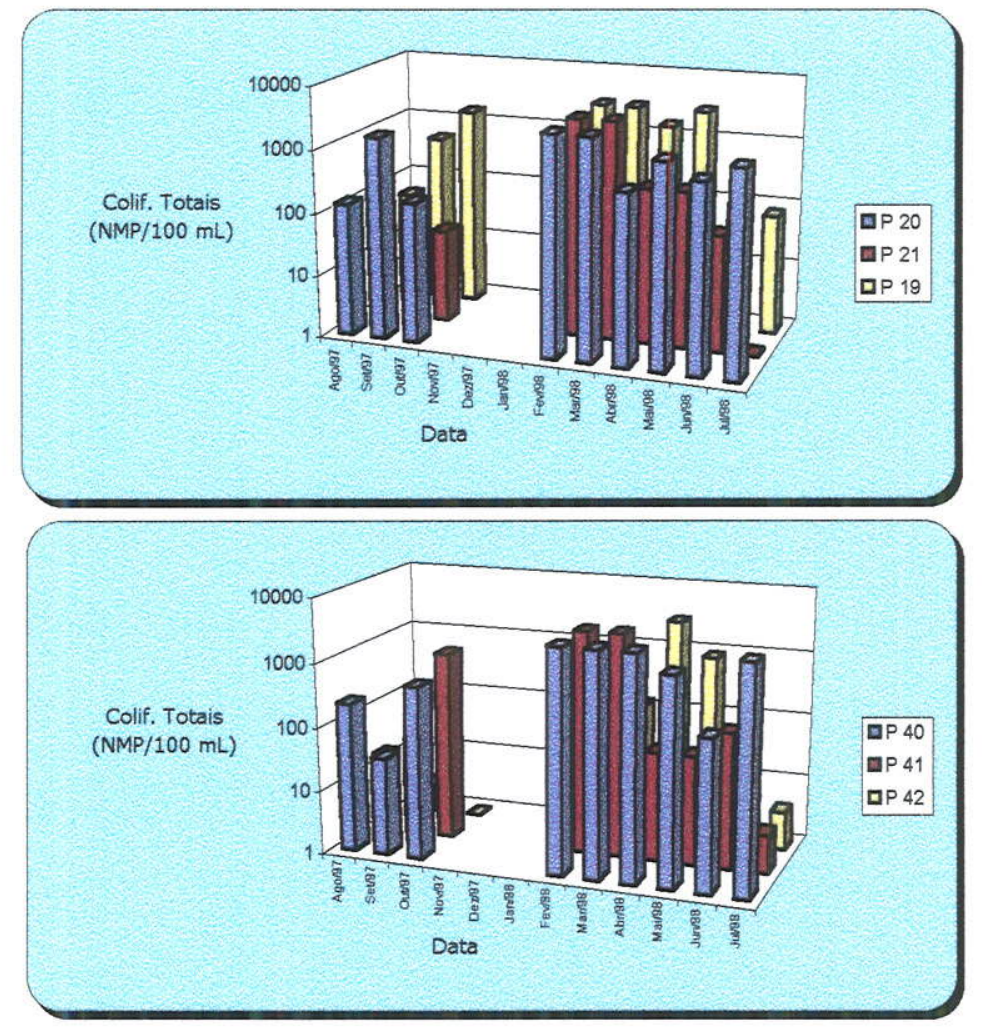

Figura 5.7 - Variação da concentração de coliformes totais nos poços monitorados 
Tabela 5.7 - Resultados analíticos de colifagos em 15 poços monitorados (01 ano hidrológico)

\begin{tabular}{|c|c|c|c|c|c|c|c|c|c|c|c|}
\hline \multirow{2}{*}{ Poço } & \multirow{2}{*}{ Posição } & \multicolumn{10}{|c|}{ COLIFAGOS (placas/100 mL) } \\
\hline & & 20.08 .1997 & 16.09 .1997 & 27.10 .1997 & 09.02 .1998 & 02.03 .1998 & 23.03 .1998 & 16.04 .1998 & 08.05 .1998 & 17.06 .1998 & 21.07 .1998 \\
\hline P 20 & montante & nd & nd & 25 & nd & nd & nd & nd & nd & nd & nd \\
\hline P 21 & intermediária & nd & nd & nd & 85 & nd & nd & nd & nd & nd & nd \\
\hline P 19 & jusante & nd & nd & nd & 1560 & 80 & 125 & nd & 670 & nd & nd \\
\hline P 44 & montante & nd & nd & nd & nd & 145 & 205 & 15 & nd & 5 & nd \\
\hline P 45 & intermediária & nd & 50 & nd & nd & nd & nd & nd & 45 & 60 & 5 \\
\hline P 46 & jusante & nd & nd & nd & nd & nd & nd & nd & 10 & nd & nd \\
\hline P 40 & montante & nd & 25 & nd & nd & nd & nd & nd & nd & 330 & nd \\
\hline P 41 & intermediária & nd & nd & 15 & nd & nd & nd & nd & nd & nd & nd \\
\hline P 42 & jusante & nd & nd & nd & nd & nd & nd & nd & nd & nd & nd \\
\hline P 51 & montante & nd & nd & nd & nd & nd & nd & nd & nd & nd & 145 \\
\hline P 49 & intermediária & nd & nd & nd & nd & nd & nd & nd & 20 & 85 & nd \\
\hline P 04 & jusante & nd & nd & nd & nd & nd & nd & nd & nd & nd & nd \\
\hline P 26 & montante & nd & nd & nd & nd & nd & nd & nd & nd & nd & nd \\
\hline P 29 & intermediária & nd & nd & nd & 5 & 40 & 125 & 75 & 25 & 285 & nd \\
\hline P 30 & jusante & nd & 620 & nd & nd & nd & nd & nd & nd & nd & nd \\
\hline
\end{tabular}

$n d=$ não detectado 

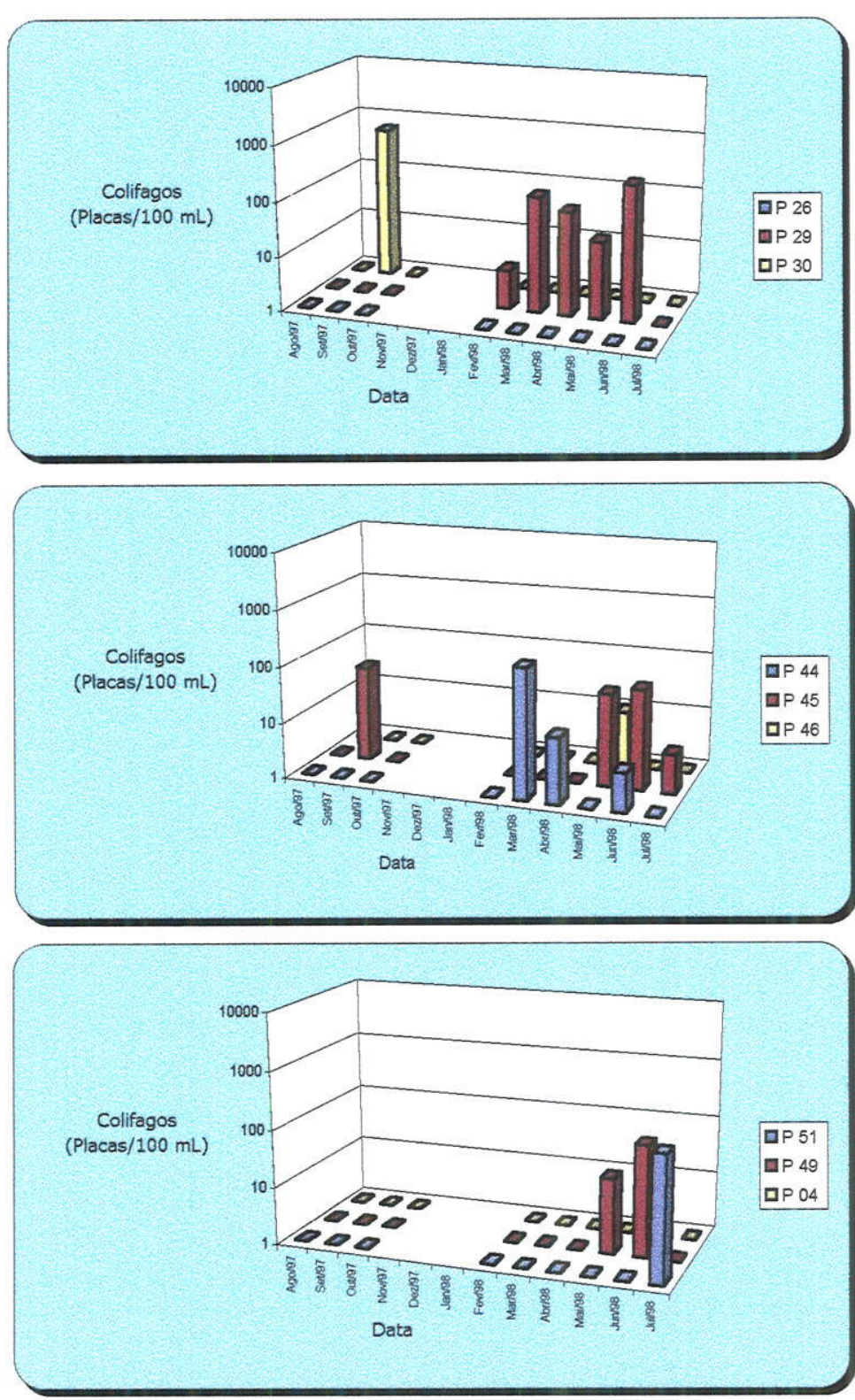
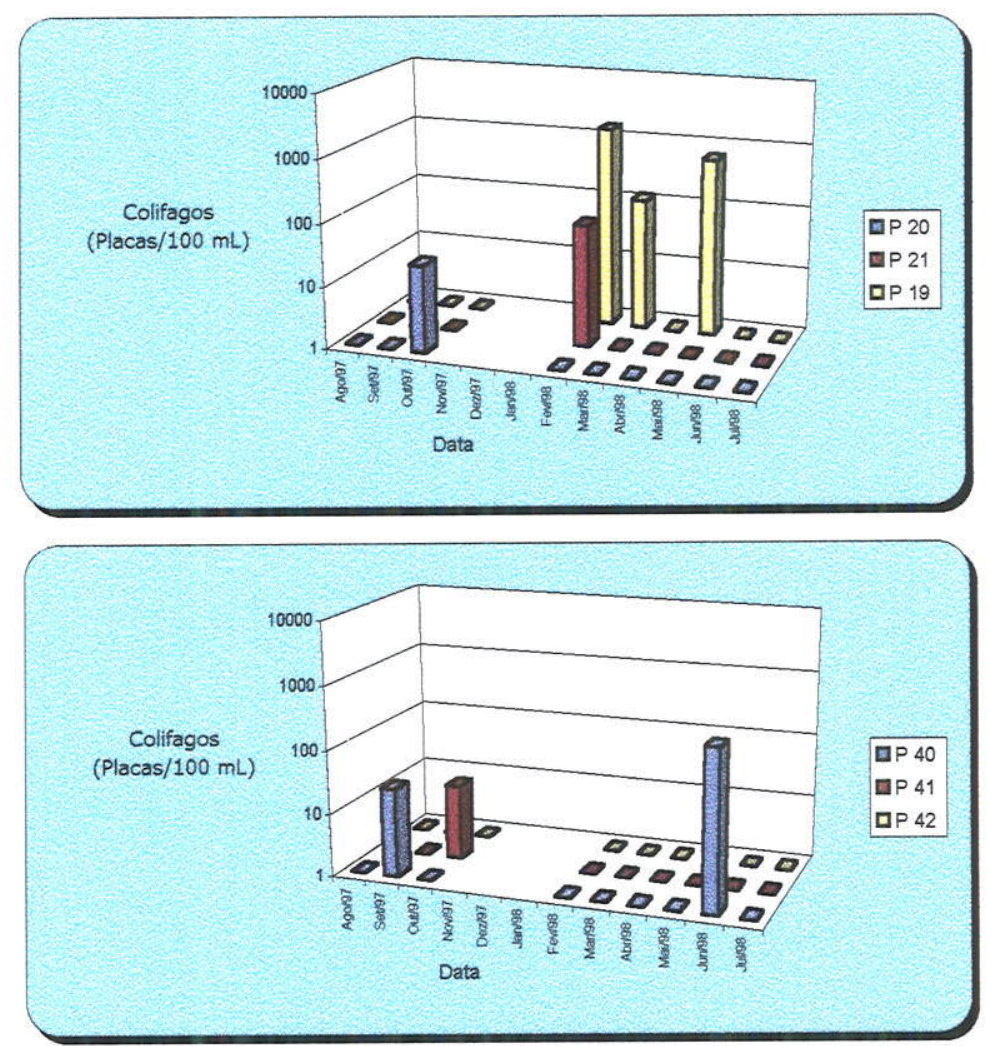

Figura 5.8 - Variação da concentração de colifagos nos poços monitorados 
Os colifagos, utilizados como indicadores de contaminação fecal, foram menos eficientes quando comparados aos coliformes fecais. Foram detectados principalmente nos meses de maior precipitações pluviométricas, porém, na maioria das vezes, não ocorreram quando a concentração de coliformes fecais era elevada.

Também não mostrou correlação entre poços localizados na mesma vertente, ocorrendo de forma isolada, apesar de mostrar uma pequena tendência de ocorrer mais freqüentemente em poços intermediários e de posição jusante.

Em relação à sua ocorrência nas diferentes regiões do bairro, os colifagos foram detectados principalmente nos poços monitorados na região norte (P26P29-P30 / P20-P21-P19 / P44-P45-46), confirmando as condições sanitárias mais precárias daquela região.

Foram monitorados 02 conjuntos de 03 poços, localizados na região norte do bairro Recanto Mônica, em relação a Salmonella e Cryptosporidium. Foram monitorados os poços 20-21-19 e 44-45-46 em 04 épocas distintas. Os resultados são apresentados na Tabela $\mathbf{5 . 8}$. Os métodos analíticos empregados são qualitativos, indicando a presença ou ausência daqueles microorganismos nas amostras de água.

Não foi detectado Salmonella nos 06 poços monitorados. Cryptosporidium foi detectado em quase todos os poços, principalmente nos meses mais chuvosos, acompanhando a tendência dos coliformes fecais. Nas amostras de água do P20 (montante) não foram detectados Cryptosporidium. Por outro lado, as amostras de água do P44, também de posição montante, embora influenciado localmente por uma fonte de contaminação fecal já discutida, apresentaram cryptosporidium em quase todos os monitoramentos, mostrando que há correlação entre aqueles protozoários e as fezes de animais (cavalos). 
Tabela 5.8 - Resultados analíticos de Salmonella e Cryptosporidium em 06 poços monitorados

\begin{tabular}{|c|c|c|c|c|c|c|c|c|c|}
\hline \multirow{2}{*}{ Poços } & \multirow{2}{*}{ Posição } & \multicolumn{2}{|c|}{ 16.09.1997 } & \multicolumn{2}{|c|}{09.02 .1998} & \multicolumn{2}{|c|}{23.03 .1998} & \multicolumn{2}{|c|}{08.05 .1998} \\
\hline & & $\begin{array}{c}\text { Salmonella } \\
\text { (em 5L) }\end{array}$ & $\begin{array}{c}\text { Cryptosporidium } \\
\text { (em 10L) }\end{array}$ & $\begin{array}{c}\text { Salmonella } \\
\text { (em 5L) }\end{array}$ & $\begin{array}{c}\text { Cryptosporidium } \\
\text { (em 10L) }\end{array}$ & $\begin{array}{c}\text { Salmonella } \\
\text { (em 5L) }\end{array}$ & $\begin{array}{c}\text { Cryptosporidium } \\
\text { (em 10L) }\end{array}$ & $\begin{array}{c}\text { Salmonella } \\
\text { (em 5L) }\end{array}$ & $\begin{array}{c}\text { Cryptosporidium } \\
\text { (em 10L) }\end{array}$ \\
\hline P 20 & montante & Ausente & Ausente & Ausente & Ausente & Ausente & Ausente & Ausente & Ausente \\
\hline P 21 & intermediária & Ausente & Ausente & Ausente & Presente & Ausente & Presente & Ausente & Presente \\
\hline P 19 & jusante & Ausente & Presente & Ausente & Presente & Ausente & Presente & Ausente & Presente \\
\hline P 44 & montante & Ausente & Presente & Ausente & Ausente & Ausente & Presente & Ausente & Presente \\
\hline P 45 & intermediária & Ausente & Ausente & Ausente & Presente & Ausente & Presente & Ausente & Presente \\
\hline P 46 & jusante & Ausente & Ausente & Ausente & Presente & Ausente & Presente & Ausente & Presente \\
\hline
\end{tabular}


Na Tabela $\mathbf{5 . 9}$ são apresentados os resultados das análises de coliformes fecais e totais em amostras de água de 02 córregos localizados na região norte do bairro Recanto Mônica, monitorados em 03 épocas distintas. A localização dos pontos monitorados é mostrada na Figura 4.4. Os pontos monitorados são influenciados pelas vertentes dos poços 20-21-19 e 44-4546.

Amostras de água dos 02 córregos apresentaram elevada concentração de coliformes fecais e totais, ultrapassando o limite quantitativo da escala $(>1.600 \mathrm{NMP} / 100 \mathrm{~mL})$. Estes organismos nas águas superficiais podem ser derivados da descarga da água subterrânea contaminada e/ou induzidos diretamente pelos efluentes de fossas de residências mais próximas (fundo de vales).

Na Tabela 5.10 são apresentados os resultados analíticos de Salmonella e Cryptosporidium de amostras do esgoto coletado nas fossas 19 e 21, cujo posicionamento é mostrado na Figura 4.4.

Não foi detectado Salmonella em ambas as fossas. Cryptosporidium ocorreu nas duas fossas monitoradas, comprovando que este protozoário está presente nas fezes de moradores do bairro.

Os laudos laboratoriais das análises microbiológicas encontram-se no Anexo B.

\subsubsection{Análises químicas}

Para facilitar a apresentação e discussão dos resultados das análises químicas, os mesmos foram subdivididos em 02 seções, ânions e cátions, apresentados a seguir.

\subsubsection{Monitoramento dos ânions}

$\mathrm{Na}$ Tabela 5.11 são apresentados os resultados do primeiro monitoramento químico $(16.09 .1997)$ em relação às concentrações de ânions na água subterrânea dos 15 poços monitorados. Na Tabela $\mathbf{5 . 1 2}$ são apresentados os resultados do segundo monitoramento químico (02.03.1998). 


\section{Tabela 5.9 - Resultados analíticos de coliformes fecais e totais em 02 córregos monitorados}

\begin{tabular}{|c|c|c|c|c|c|c|}
\hline \multirow{3}{*}{ Córregos } & \multicolumn{2}{|c|}{$\mathbf{1 6 . 0 9 . 1 9 9 7}$} & \multicolumn{2}{c|}{$\mathbf{0 2 . 0 3 . 1 9 9 8}$} & \multicolumn{2}{c|}{$\mathbf{0 8 . 0 5 . 1 9 9 8}$} \\
\cline { 2 - 7 } & $\begin{array}{c}\text { CF } \\
(\mathrm{NMP} / 100 \mathrm{~mL})\end{array}$ & $\begin{array}{c}\text { CT } \\
(\mathrm{NMP} / 100 \mathrm{~mL})\end{array}$ & $\begin{array}{c}\text { CF } \\
(\mathrm{NMP} / 100 \mathrm{~mL})\end{array}$ & $\begin{array}{c}\text { CT } \\
(\mathrm{NMP} / 100 \mathrm{~mL})\end{array}$ & $\begin{array}{c}\text { CF } \\
(\mathrm{NMP} / 100 \mathrm{~mL})\end{array}$ & $\begin{array}{c}\text { CT } \\
(\mathrm{NMP} / 100 \mathrm{~mL})\end{array}$ \\
\hline Córrego 1 (C1) & $>1600$ & $>1600$ & $>1600$ & $>1600$ & $>1600$ & $>1600$ \\
\hline Córrego 2 (C2) & $>1600$ & $>1600$ & $>1600$ & $>1600$ & $>1600$ & $>1600$ \\
\hline
\end{tabular}

$C F=$ coliformes fecais

$C T=$ coliformes totais 
Tabela 5.10 - Resultados analíticos de Salmonella e Cryptosporidium em 02 fossas monitoradas

\begin{tabular}{|c|c|c|c|c|}
\hline \multirow{2}{*}{ Fossa } & \multicolumn{2}{|c|}{$\mathbf{1 6 . 0 4 . 1 9 9 8}$} & \multicolumn{2}{c|}{17.06 .1998} \\
\cline { 2 - 5 } & $\begin{array}{c}\text { Salmonella } \\
\text { (em 1L) }\end{array}$ & $\begin{array}{c}\text { Cryptosporidium } \\
\text { (em 1L) }\end{array}$ & $\begin{array}{c}\text { Salmonella } \\
\text { (em 1L) }\end{array}$ & $\begin{array}{c}\text { Cryptosporidium } \\
\text { (em 1L) }\end{array}$ \\
\hline F 19 & Ausente & Presente & ---- & $-\cdots-$ \\
\hline F 21 & $-\cdots--$ & $-\cdots$ & Ausente & Presente \\
\hline
\end{tabular}


Tabela 5.11 - Concentração de ânions na água subterrânea dos 15 poços monitorados
$1^{\circ}$ monitoramento (16.09.1997) - Resultados em $\mathrm{mg} / \mathrm{L}$

\begin{tabular}{|c|c|c|c|c|c|c|c|c|}
\hline Poço & Posição & $\mathrm{Cl}^{-}$ & $F^{*}$ & $\mathrm{NO}_{3}^{-}$ & $\mathrm{NO}_{2}^{-}$ & $\mathrm{Br}^{-}$ & $\mathrm{PO}_{4}{ }^{3-}$ & $\mathrm{SO}_{4}{ }^{2-}$ \\
\hline P 26 & montante & 1,41 & 0,03 & 0,98 & nd & nd & 0,78 & 0,61 \\
\hline P 29 & meja-vertente & 3,53 & 0,04 & 36.23 & nd & 0,02 & 0,01 & 0,23 \\
\hline P 30 & baixada & 14,55 & 0,24 & 11,56 & nd & 0,03 & 0,04 & 5,99 \\
\hline P 20 & montante & 1,13 & 0,04 & 9,78 & nd & no & 0,55 & 0,61 \\
\hline P 21 & meia-vertente & 11,40 & 0,23 & 54,80 & nd & 0,03 & 0,31 & 1,12 \\
\hline P 19 & baixada & 38,28 & 0,11 & 56,34 & nd & 0,16 & 0,04 & 16,63 \\
\hline P 44 & montante & 3,79 & 0,06 & 45,61 & nd & 0,04 & 0,02 & 0,66 \\
\hline P 45 & meia-vertente & 8,58 & 0,06 & 5,61 & nd & 0,19 & 0,02 & 1,48 \\
\hline P 46 & baixada & 6,06 & 0,02 & 10,29 & nd & 0,02 & 0,02 & 0,86 \\
\hline$P 40$ & montante & 2,98 & 0,04 & 1,81 & nd & 0,01 & 0,04 & 0,96 \\
\hline P 41 & meia-vertente & 10,99 & 0,03 & 71,59 & nd & 0,04 & 0,29 & 0,45 \\
\hline P 42 & baixada & 31,48 & 0,07 & 25.14 & nd & 0,47 & 0,01 & 4,52 \\
\hline$P 51$ & montante & 3,05 & nd & 3,09 & nd & 0,01 & 0,01 & 0,65 \\
\hline P 49 & meia-vertente & 16,21 & 0,02 & 87,26 & nd & 0,04 & 0,04 & 0,59 \\
\hline P 04 & baixada & 23,66 & 0,06 & 66.31 & no & 0,09 & 0,19 & 2,02 \\
\hline \multicolumn{2}{|c|}{ Limite de potabilidade * } & 250 & 1,5 & 10 & 1. & & & 250 \\
\hline
\end{tabular}

nd $=$ não detectado 

Tabela 5.12 - Concentração de ânions na água subterrânea dos 15 poços monitorados
$2^{\circ}$ monitoramento (02.03.1998) - Resultados em $\mathrm{mg} / \mathrm{L}$

\begin{tabular}{|c|c|c|c|c|c|c|c|c|}
\hline Poço & Posição & $\mathrm{Cl}^{-}$ & $\mathbf{F}^{-}$ & $\mathrm{NO}_{3}^{-}$ & $\mathrm{NO}_{2}{ }^{-}$ & $\mathrm{Br}^{-}$ & $\mathrm{PO}_{4}{ }^{3-}$ & $\mathrm{SO}_{4}{ }^{2-}$ \\
\hline P 26 & montante & 1,09 & 0,02 & 0,94 & nd & 0,01 & 0,08 & 0,38 \\
\hline P 29 & meia-vertente & 5,22 & 0,27 & 604,94 & nd & nd & 0,09 & 0,51 \\
\hline P 30 & baixada & 19,43 & 0,15 & 1386 & nd & 0,05 & 0,03 & 8,73 \\
\hline P 20 & montante & 0,81 & 0,03 & 11,90 & nd & 0,02 & 0,25 & 0,44 \\
\hline P 21 & meia-vertente & 15,84 & 0,33 & 71,98 & no & 0,03 & 0,10 & 1,60 \\
\hline P 19 & baixada & 34,59 & 0,05 & 39,80 & nd & 0,14 & 0,05 & 19,87 \\
\hline P 44 & montante & 3,72 & 0,07 & 37,62 & nd & 0,19 & 0,02 & 0,95 \\
\hline P 45 & meia-vertente & 8,01 & 0,03 & 3,68 & nd & 0,05 & 0,03 & 1,07 \\
\hline P 46 & baixada & 9,56 & 0,02 & 15,92 & nd & 0,03 & 0,02 & 0,27 \\
\hline P 40 & montante & 2,12 & 0,01 & 1,24 & nd & 0,01 & 0,02 & 0,46 \\
\hline P 41 & meia-vertente & 23,81 & 0,23 & $1,6,02$ & nd & 0,02 & 0,02 & 1,97 \\
\hline P 42 & baixada & 45,84 & 0,21 & 112,71 . & nd & 0,09 & 0,04 & 17,85 \\
\hline P 51 & montante & 2,91 & 0,01 & 3,37 & nd & 0,02 & 0,02 & 1,06 \\
\hline P 49 & meia-vertente & 14,30 & 0,05 & 90,45 & nd & 0,02 & 0,18 & 0,45 \\
\hline P 04 & baixada & 26,73 & 0,02 & 90,08 & nd & 0,05 & 0,31 & 5,35 \\
\hline \multicolumn{2}{|c|}{ Córrego 1} & 8,40 & 0,06 & 3,40 & 2,60 & 0,07 & 0,12 & 2,25 \\
\hline \multicolumn{2}{|c|}{ Córrego 2} & 5,81 & 0,03 & 5,09 & 3,02 & 0,07 & 0,07 & 1,93 \\
\hline \multicolumn{2}{|c|}{ Limite de potabilidade * } & 250 & 1,5 & 10 & 1 : & & & 250 \\
\hline
\end{tabular}

9.12.2000 do Ministério da Saúde

nd $=$ não detectado 
Em ambas as tabelas, foram destacados os resultados que ultrapassaram - limite de potabilidade estabelecido pela Portaria $n^{\circ} 1.469$ de 29.12.2000 do Ministério da Saúde. Nos 02 primeiros monitoramentos, foram analisados cloreto, fluoreto, nitrato, nitrito, bromo, fosfato e sulfato.

A Tabela $\mathbf{5 . 1 3}$ mostra os resultados do terceiro monitoramento químico (17.06.1998) em relação às concentrações de ânions na água subterrânea dos 15 poços monitorados. Neste último monitoramento foram analisados cloreto, nitrato, amônio e amônia. O amônio é um cátion e a amônia um gás, porém foram incluídos naquela tabela por se tratarem de espécies químicas nitrogenadas, as quais serão discutidas juntamente com o nitrato.

A Figura $\mathbf{5 . 9}$ mostra a variação das concentrações de cloreto na água subterrânea, nos 15 poços analisados em 03 períodos de monitoramento. 0 aspecto mais evidente no padrão de distribuição do cloreto se refere à sua distribuição ao longo das vertentes topográficas. Sua concentração é crescente ao longo de todas as vertentes monitoradas, de montante para jusante. Como se trata de um ânion relativamente inerte, é um bom indicativo do crescente aporte de soluto derivado das fossas ao longo das vertentes.

As concentrações de cloreto apresentaram amplitude variada, de 0,81 $\mathrm{mg} / \mathrm{L}$ (P20) até $47,9 \mathrm{mg} / \mathrm{L}$ (P19). As maiores concentrações ocorreram nas vertentes P20-P21-P19, P40-P41-P42 e P51-P49-P04.

A Figura 5.10 mostra a variação das concentrações de fluoreto na água subterrânea, nos 15 poços analisados em 02 períodos de monitoramento. As concentrações determinadas foram relativamente baixas, variando de não detectado (P51) até $0,33 \mathrm{mg} / \mathrm{L}$ (P21). As maiores concentrações ocorreram nas vertentes P26-P29-P30, P20-P21-P19 e P40-P41-P42.

A Figura 5.11 mostra a variação das concentrações de nitrato na água subterrânea, nos 15 poços analisados em 03 períodos de monitoramento. Assim como o cloreto, o aspecto mais evidente no padrão de distribuição do nitrato se refere à sua distribuição ao longo das vertentes topográficas. Da mesma forma que o cloreto, esperava-se no início da pesquisa que sua concentração fosse crescente por toda extensão das vertentes investigadas. 

Tabela 5.13 - Concentração de ânions na água subterrânea dos 15 poços monitorados
\[ 3^{\circ} \text { monitoramento (16.06.1998) - Resultados em } \mathrm{mg} / \mathrm{L} \]

\begin{tabular}{|c|c|c|c|c|c|}
\hline Poço & Posição & $\mathrm{Cl}^{-}$ & $\mathrm{NO}_{3}{ }^{-}$ & $\mathrm{NH}_{4}{ }^{+}$ & $\mathrm{NH}_{3}(\mathrm{~g})$ \\
\hline P 26 & montante & 13,1 & nd & nd & nd \\
\hline P 29 & meia-vertente & 7,25 & 7,78 & nd & nd \\
\hline P 30 & baixada & 14,2 & 2,77 & nd & nd \\
\hline P 20 & montante & 15,6 & 3,59 & nd & nd \\
\hline P 21 & meia-vertente & 33,1 & 15,7 & nd & nd \\
\hline P 19 & baixada & 47,9 & 7,78 & 6,22 & 5,88 \\
\hline P 44 & montante & 8,28 & 10,4 & nd & nd \\
\hline P 45 & meia-vertente & 8,28 & 1,79 & nd & nd \\
\hline P 46 & baixada & 7,63 & 3,03 & nd & nd \\
\hline$P 40$ & montante & 5,01 & nd & nd & nd \\
\hline P 41 & meia-vertente & 19,6 & 22,1 & no & nd \\
\hline P 42 & baixada & 39,0 & 14,6 & nd & nd \\
\hline P 51 & montante & 5,45 & 1,33 & nd & nd \\
\hline P 49 & mela-vertente & 26,8 & 41,2 & 2,00 & 1,89 \\
\hline P 04 & baixada & 38,2 & 15,3 & nd & nd \\
\hline \multicolumn{2}{|c|}{ Limite de potabilidade * } & 250 & 10 & & \\
\hline
\end{tabular}

"Portaria $n^{\circ} 1469$ de 29.12.2000 do Ministério da Saúde $n d=n \tilde{o}$ detectado 

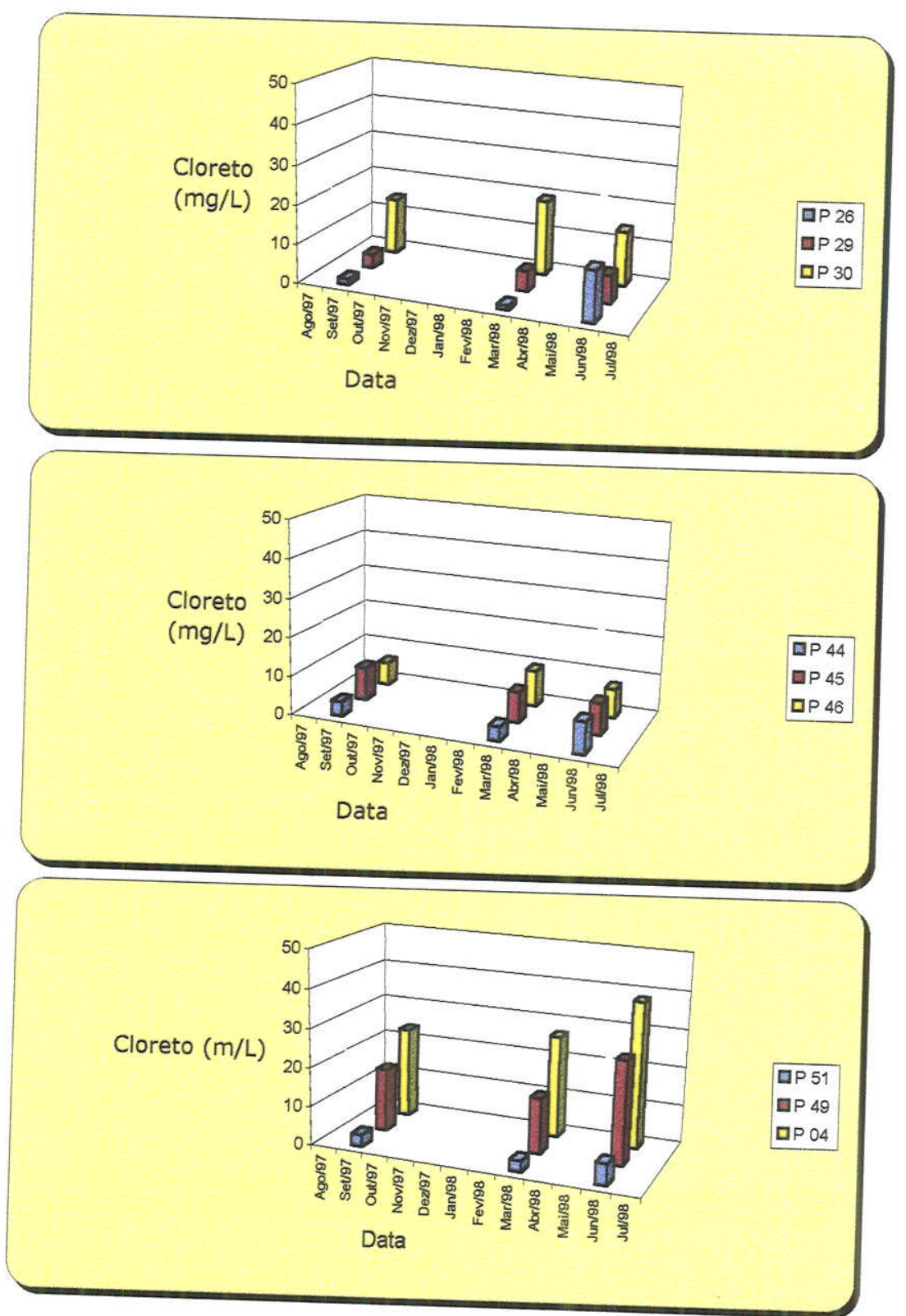
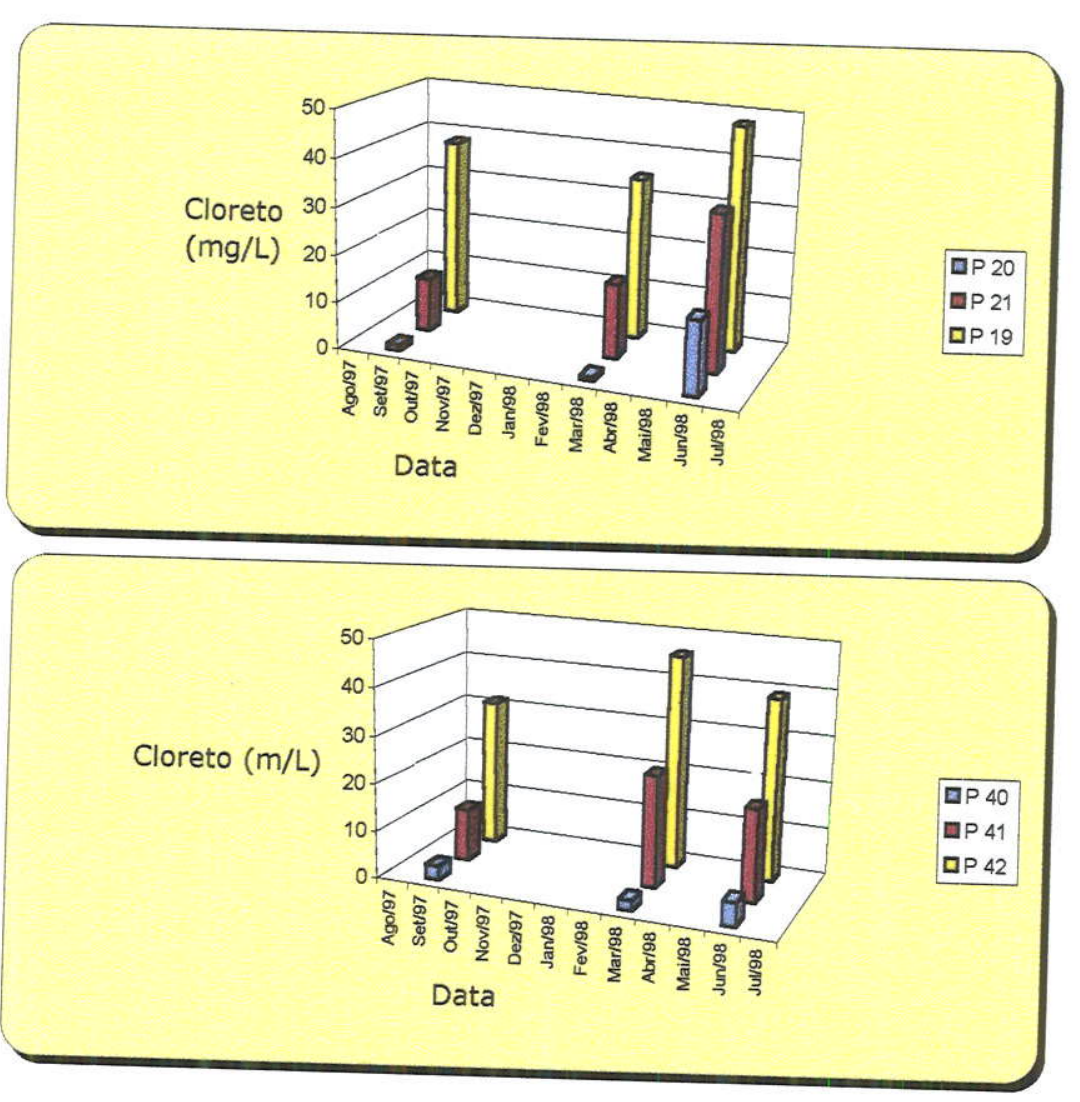

Figura 5.9 - Variação da concentração de cloreto nos poços monitorados 

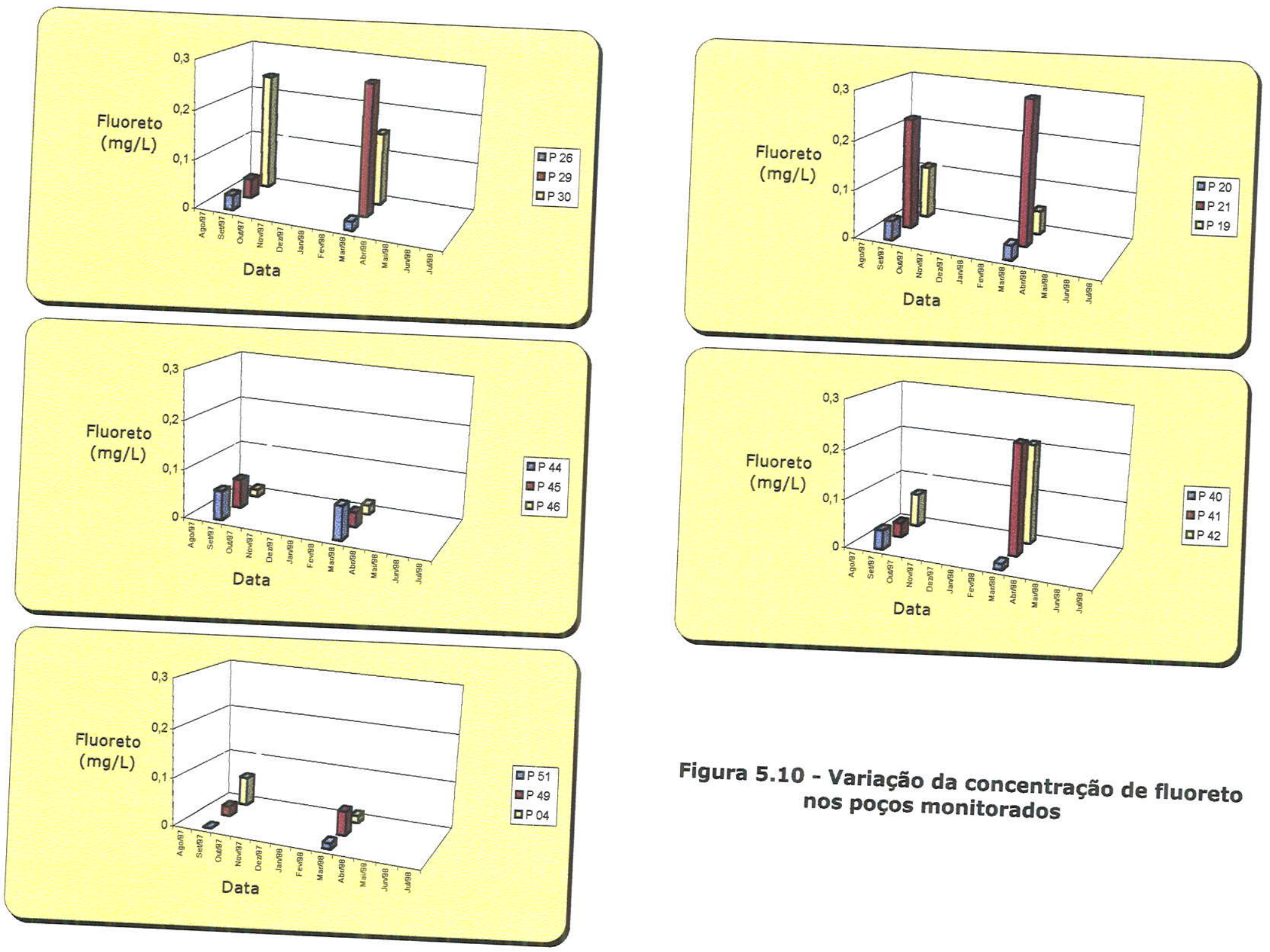

Figura 5.10 - Variação da concentração de fluoreto
nos poços monitorados 

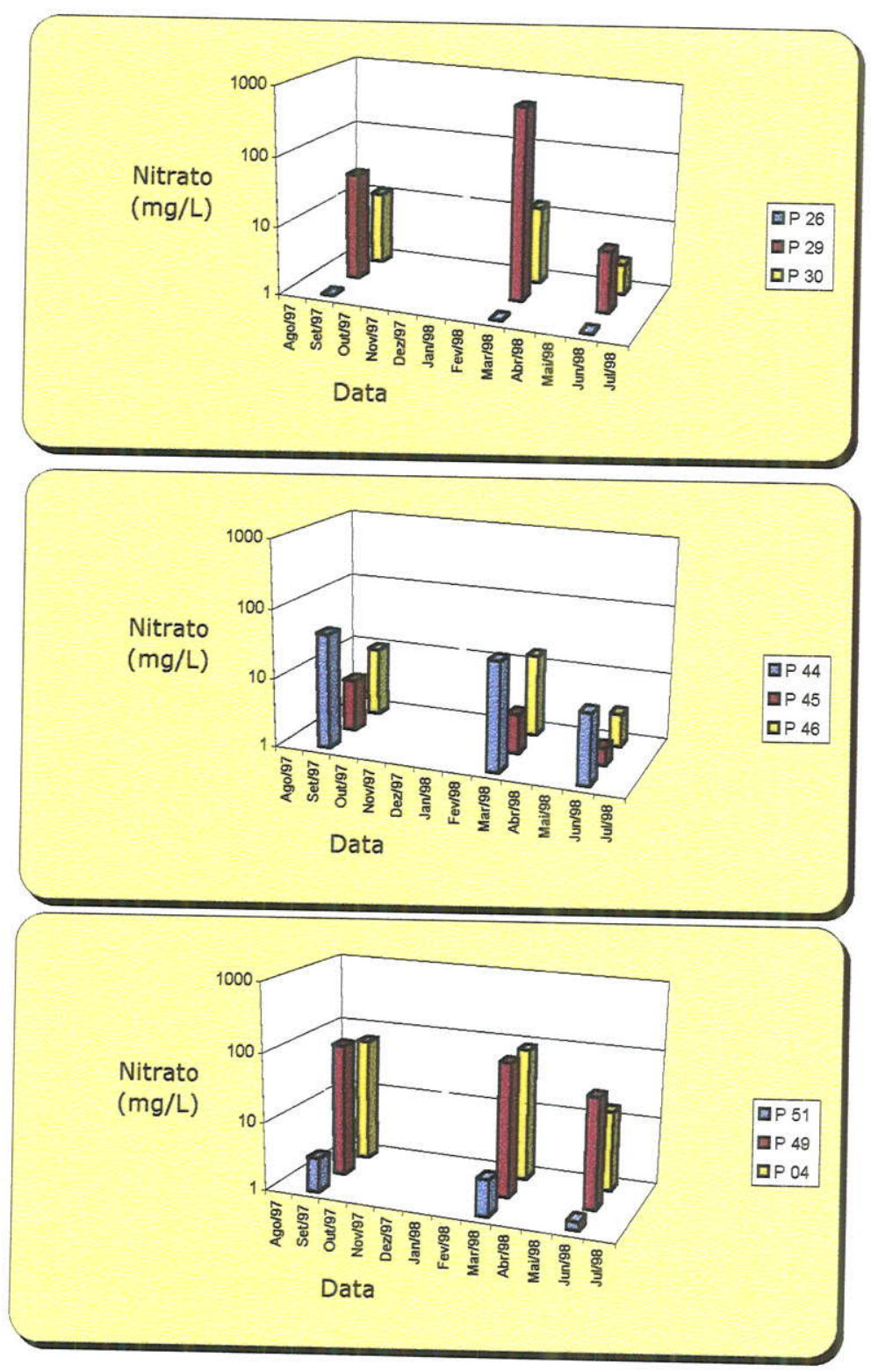
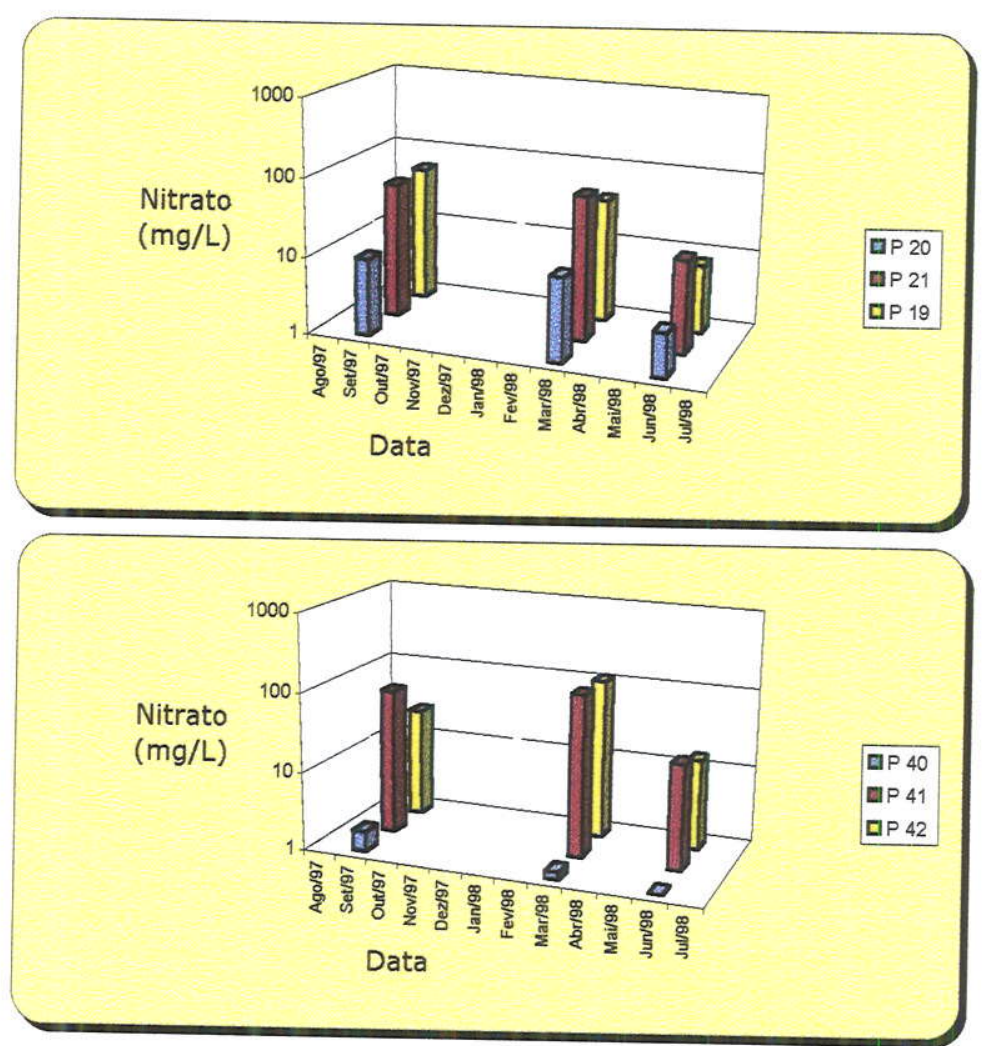

Figura 5.11 - Variação da concentração de nitrato nos poços monitorados 
Porém, as concentrações máximas de nitrato ocorreram, em geral, na posição intermediária das vertentes. A partir daí, as concentrações diminuíram sensivelmente. Este padrão somente não ocorreu na vertente P44-P45-P46, a qual apresentou elevadas concentrações de nitrato já no poço de montante (P44), em função de existir neste local uma criação de cavalos, com matéria fecal sobre o solo, influenciando a qualidade da água subterrânea local.

O ânion nitrato, ao contrário do cloreto, sofre grande influência das variações do ambiente aquoso. Ele se torna instável em ambientes redutores, quando, por exemplo, a presença de oxigênio dissolvido diminui (queda de Eh). Neste caso, podem surgir espécies nitrogenadas mais estáveis nestas condições, como é o caso do amônio e da amônia. Analisando a Tabela 5.13, verifica-se que estas espécies aparecem em alguns poços de posição intermediária e de jusante, indicando que este processo de redução deve
ocorrer.

A amplitude da concentração de nitrato foi elevada em todas as vertentes, variando de não detectado até concentrações muito altas $(604,94$ mg/L no P29), ultrapassando o limite estabelecido pela Portaria $n^{\circ} 1.469$ de 29.12.2000 do Ministério da Saúde (10 mg/L).

A Figura $\mathbf{5 . 1 2}$ mostra a variação das concentrações de brometo na água subterrânea, nos 15 poços analisados em 02 períodos de monitoramento. As concentrações determinadas foram relativamente baixas, variando de não detectado (P20, P26 e P29) até $0,47 \mathrm{mg} / \mathrm{L}$ (P42). As maiores concentrações ocorreram nas vertentes P20-P21-P19, P44-P45-P46 e P40-P41-P42. A amplitude das concentrações de brometo seguiu o mesmo padrão do cloreto, aumentando de montante para jusante em relação às vertentes monitoradas.

A Figura 5.13 mostra a variação das concentrações de fosfato na água subterrânea, nos 15 poços analisados em 02 períodos de monitoramento. As concentrações determinadas foram relativamente baixas, variando de 0,01 $\mathrm{mg} / \mathrm{L}$ (P29 e P42) até $0,78 \mathrm{mg} / \mathrm{L}$ (P26). As maiores concentrações ocorreram nas vertentes P26-P29-P30, P20-P21-P19 e P51-P49-P04. A amplitude das concentrações de fosfato em relação às vertentes não seguiu um padrão definido, apresentado concentrações mais elevadas tanto em poços de montante, quanto intermediários e de jusante. 

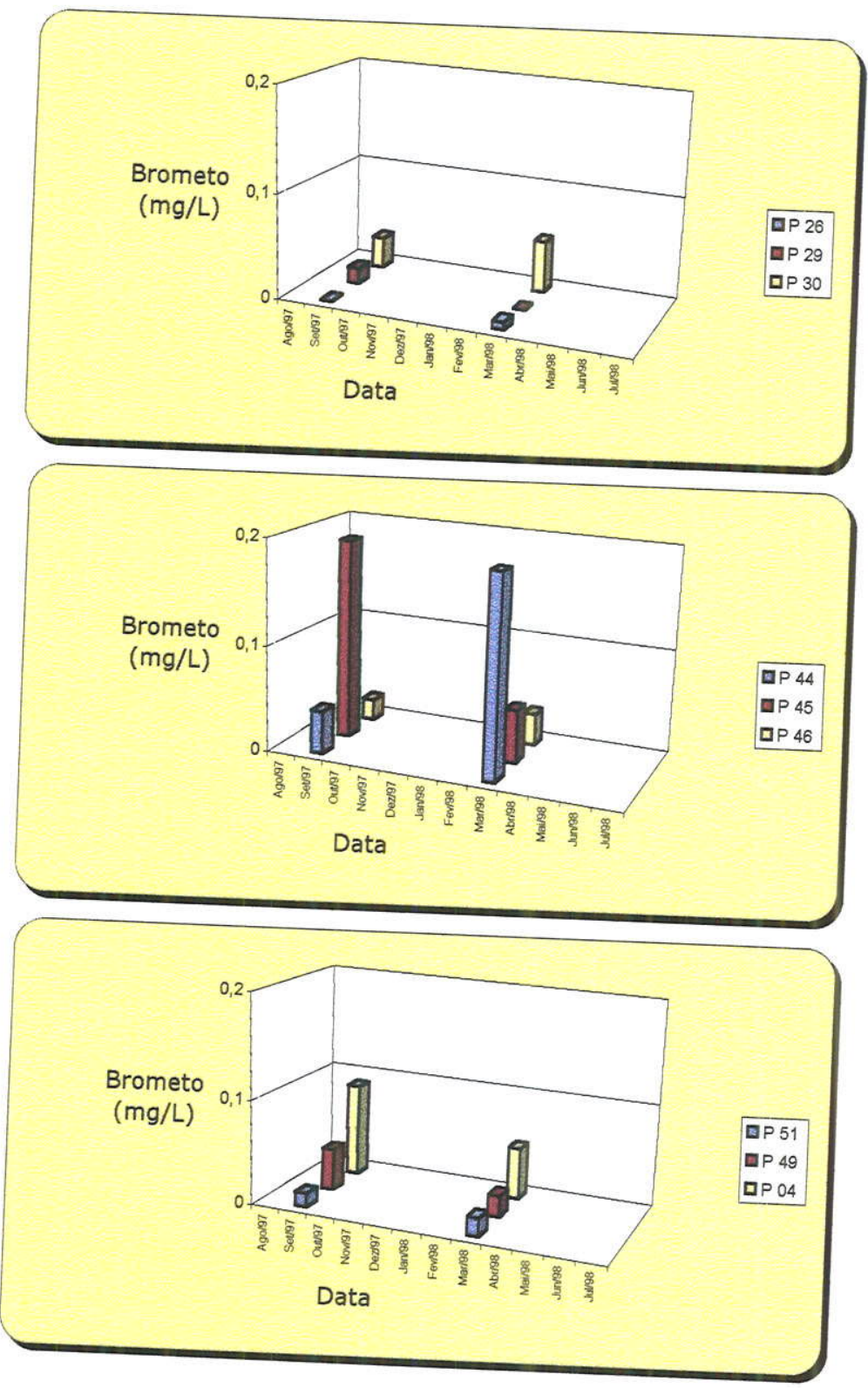
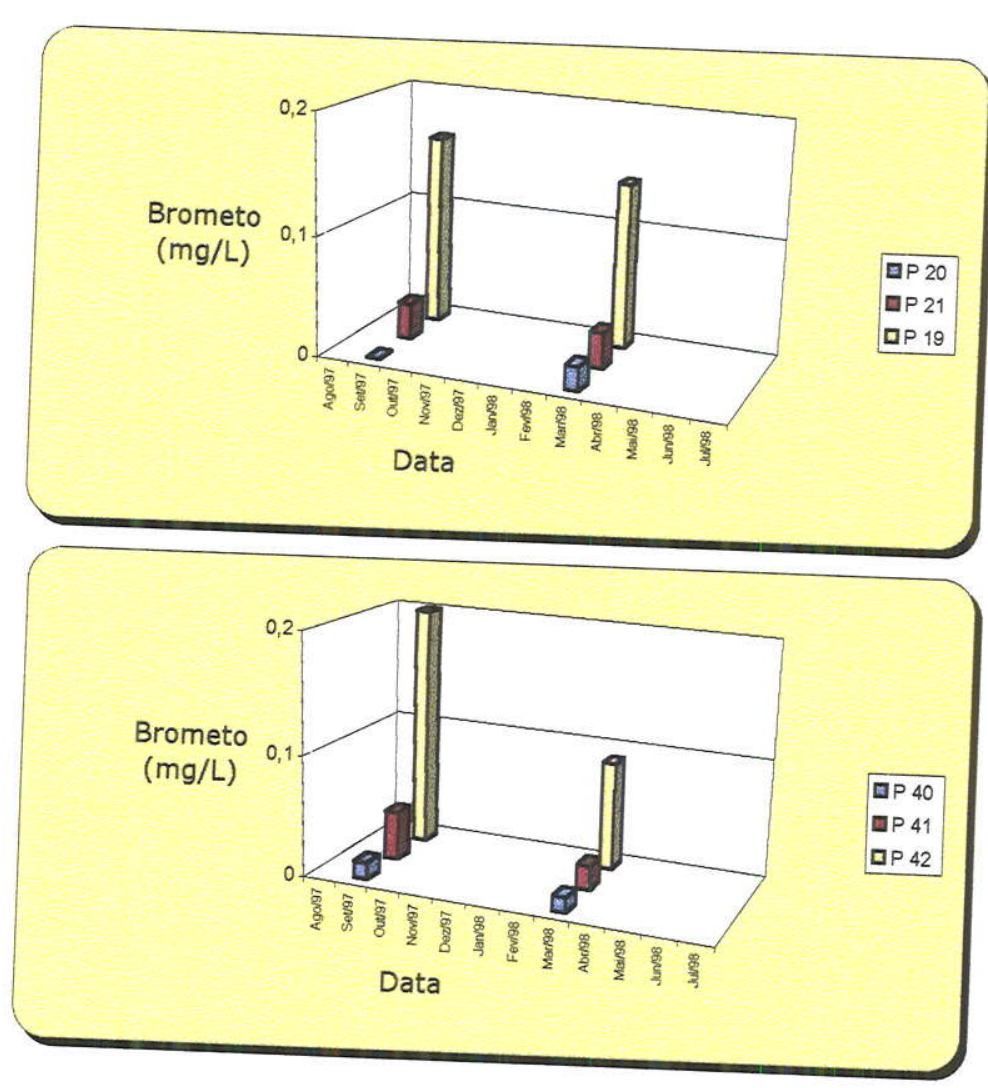

Figura 5.12 - Variação da concentração de brometo nos poços monitorados 

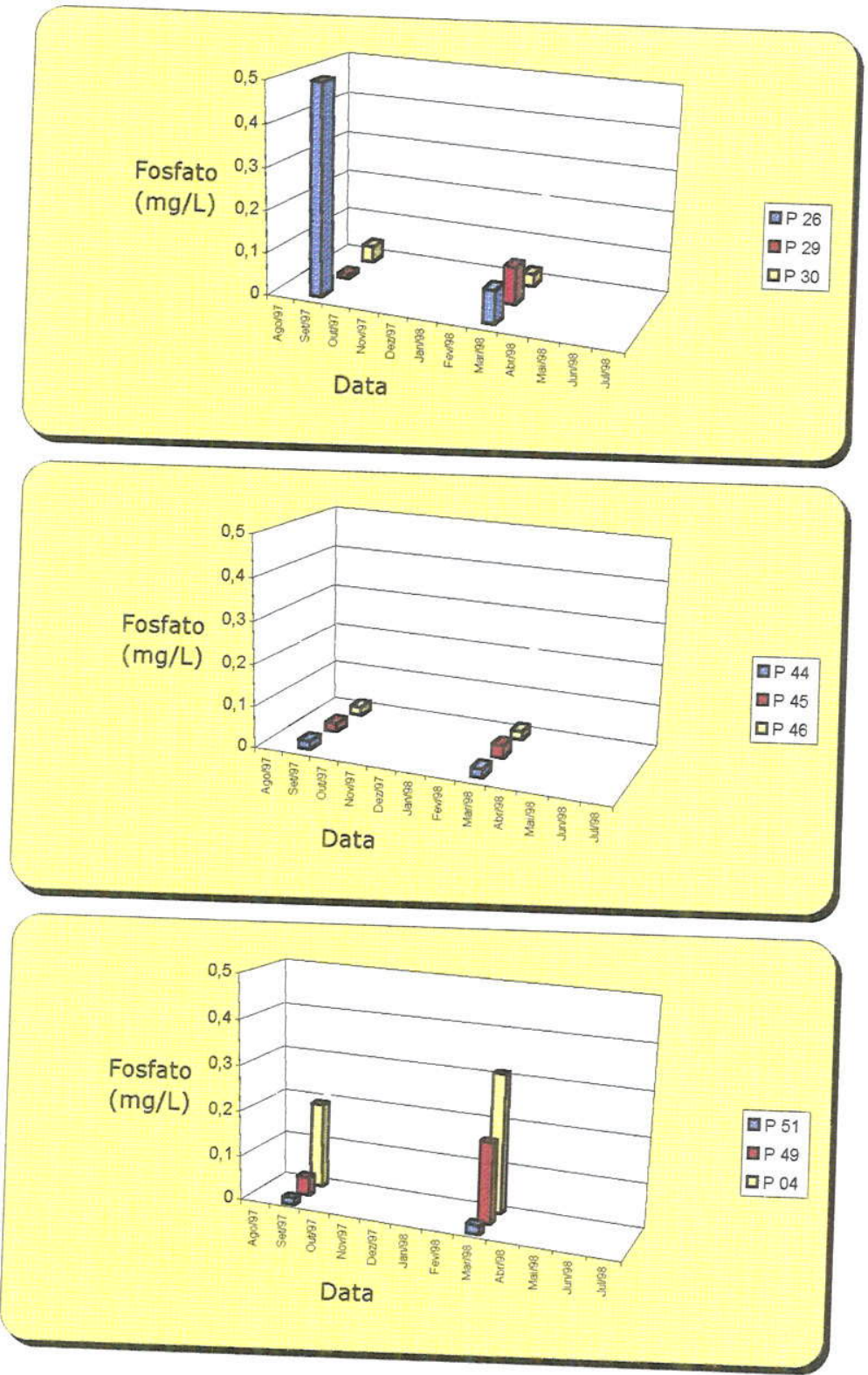
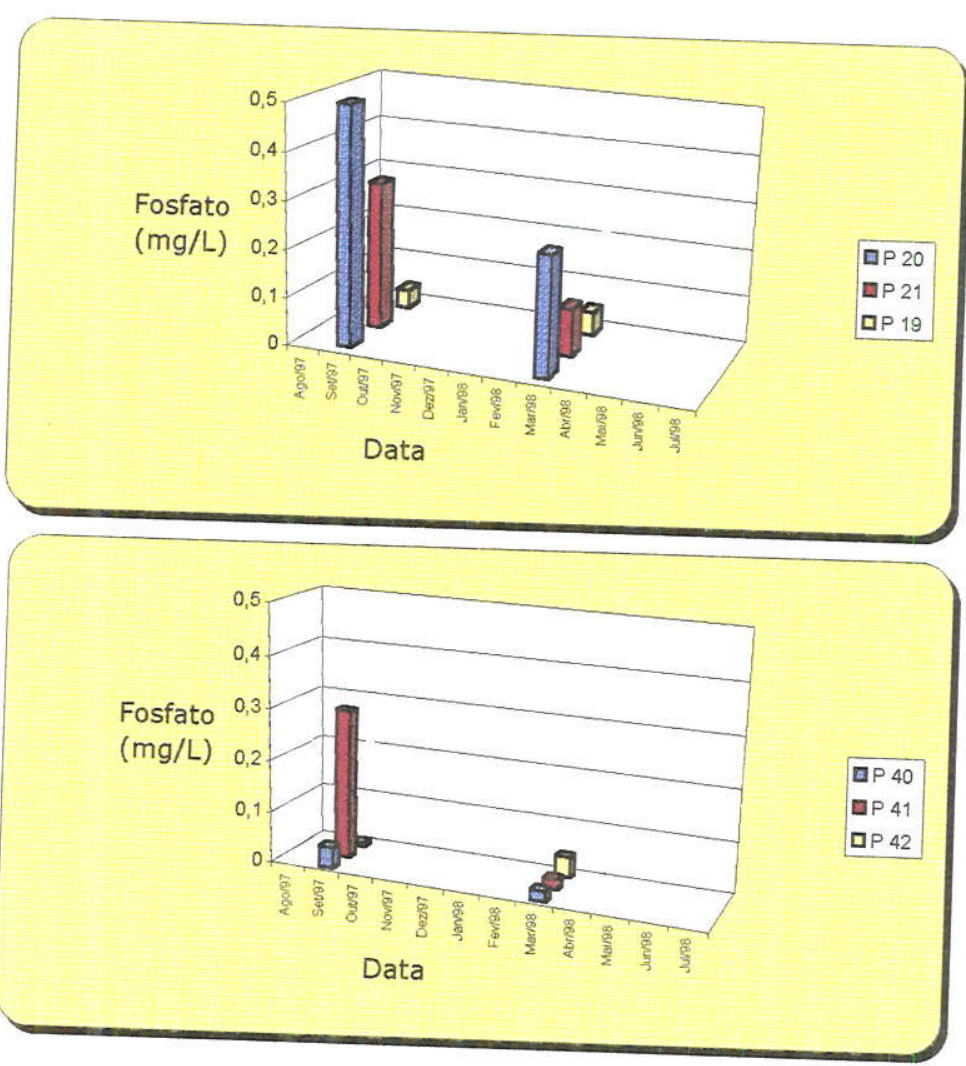

Figura 5.13 - Variação da concentração de fosfato nos poços monitorados 
A Figura 5.14 mostra a variação das concentrações de sulfato na água subterrânea, nos 15 poços analisados em 02 períodos de monitoramento. As concentrações determinadas foram relativamente baixas, variando de 0,23 $\mathrm{mg} / \mathrm{L}$ (P29) até 19,87 mg/L (P19). As maiores concentrações ocorreram nas vertentes P26-P29-P30, P40-P41-P42 e P51-P49-P04. Nestas vertentes, a amplitude das concentrações de sulfato seguiu o mesmo padrão do cloreto, aumentando de montante para jusante em relação às vertentes monitoradas. Nas demais vertentes, as concentrações foram baixas e com pouca variação.

No segundo monitoramento químico, foram monitorados 02 pontos de córregos (mostrados na Figura 4.3), cujos resultados são apresentados na Tabela 5.12. Em geral, os ânions apresentaram valores compatíveis com a média da concentração das águas subterrâneas, com exceção do nitrato, que apresentou valores menores quando comparados àqueles observados nos poços monitorados. Entretanto, o nitrito, nunca detectado na água subterrânea, ocorreu nos 02 pontos monitorados nos córregos. Este fato evidencia que o ambiente aquático nos córregos deve ser redutor, devido à provável quantidade de matéria orgânica existente e, conseqüentemente, baixa oxigenação da água, o que favorece a ocorrência de espécies nitrogenadas na forma reduzida (nitrito) e baixa concentração de nitrato.

\subsubsection{Monitoramento dos cátions}

Na Tabela $\mathbf{5 . 1 4}$ são apresentados os resultados do primeiro monitoramento químico (16.09.1997) em relação às concentrações de cátions na água subterrânea dos 15 poços monitorados. Na Tabela $\mathbf{5 . 1 5}$ são apresentados os resultados do segundo monitoramento químico (02.03.1998).

Em ambas as tabelas, foram destacados os resultados que ultrapassaram o limite de potabilidade estabelecido pela Portaria $n^{\circ} 1.469$ de 29.12.2000 do Ministério da Saúde. Foram analisados sódio, potássio, cálcio, magnésio, ferro total, manganês, alumínio, bário, estrôncio, níquel, chumbo, cobre, zinco e cromo total. 

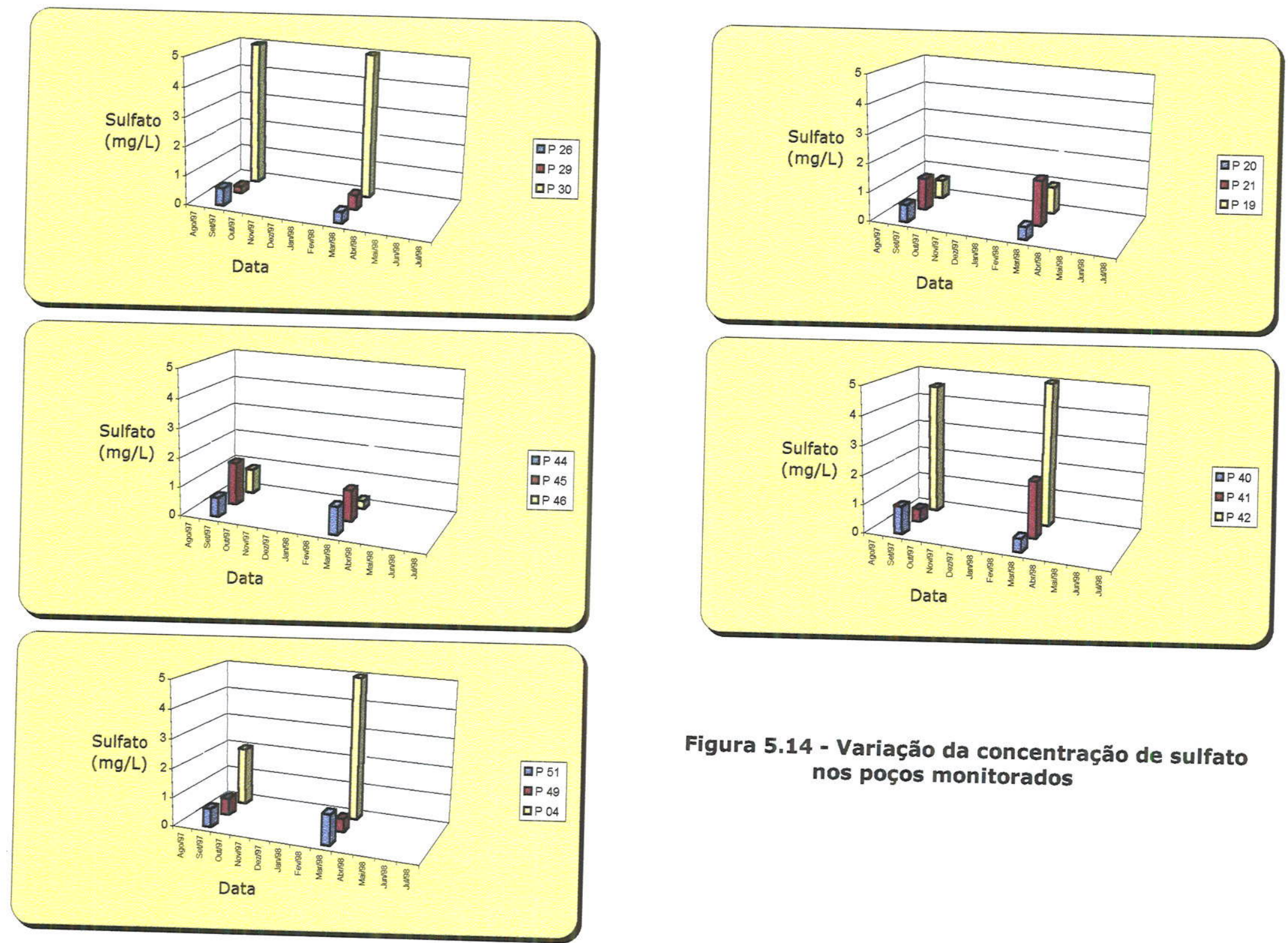

Figura 5.14 - Variação da concentração de sulfato nos poços monitorados 
Tabela 5.14 - Concentração de cátions na água subterrânea dos 15 poços monitorados $1^{\circ}$ monitoramento (16.09.1997) - Resultados em mg/L

\begin{tabular}{|c|c|c|c|c|c|c|c|c|c|c|c|c|c|c|c|}
\hline Poço & Posição & $\mathrm{Na}^{+}$ & $K^{+}$ & $\mathrm{Ca}^{2+}$ & $\mathrm{Mg}^{2+}$ & Fe total & $\mathrm{Mn}^{2+}$ & $\mathrm{Al}^{3+}$ & $8 a^{2+}$ & $S \mathrm{r}^{2+}$ & $\mathrm{Ni}^{2+}$ & $\mathrm{Pb}^{2+}$ & $\mathrm{Cu}^{2+}$ & $\mathrm{Zn}^{2+}$ & Cr total \\
\hline P 26 & montante & 4,00 & 3,00 & 3,90 & 0,95 & 0,20 & nd & 0,19 & 0,09 & 0,05 & nd & nd & nd & nd & nd \\
\hline$P 29$ & meia-vertente & 8,20 & 2,90 & 3,85 & 3,35 & nd & 0,02 & 0,08 & 0,44 & 0,08 & nd & nd & nd & nd & nd \\
\hline P 30 & baixada & 15,5 & 2,30 & 30,6 & 1,25 & 0,08 & 0,02 & 0,13 & 0,19 & 0,21 & nd & nd & 0,01 & nd & nd \\
\hline P 20 & montante & 1,60 & 2,00 & 5,05 & 1,90 & 0,09 & nd & 0,14 & 0,08 & 0,10 & nd & nd & nd & nd & nd \\
\hline$P 21$ & meia-vertente & 14,0 & 5,70 & 5,60 & 4,75 & 0,07 & 0,05 & 0,34 & 076 & 0,10 & nd & nd & nd & nd & nd \\
\hline P 19 & baixada & 34,0 & 15,0 & 26,6 & 4,80 & 0,24 & 0,09 & 0,16 & 0,14 & 0,16 & nd & nd & nd & nd & nd \\
\hline P 44 & montante & 5,90 & 5,10 & 4,00 & 4,25 & 0,18 & 0,01 & 0,23 & 0,41 & 0,08 & nd & nd & nd & nd & nd \\
\hline$P 45$ & meia-vertente & 8,00 & 2,20 & 8,60 & 0,75 & 0,88 & 0,14 & 0,13 & 0,05 & 0,08 & nd & nd & nd & nd & 0,01 \\
\hline$P 46$ & baixada & 5,90 & 1,90 & 3,30 & 0,35 & 0,04 & 0,01 & 0,14 & 0,05 & nd & nd & nd & nd & nd & 0,01 \\
\hline P 40 & montante & 1,70 & 1,30 & 9,70 & 0,25 & 0,13 & nd & 0,30 & 0,05 & 0,15 & nd & nd & nd & nd & 0,01 \\
\hline P 41 & meia-vertente & 25,0 & 2,20 & 6,70 & 1,45 & 0,03 & 0,02 & $0,40 \%$ & 0,06 & 0,09 & nd & nd & nd & nd & nd \\
\hline P 42 & baixada & 21,0 & 3,80 & 9,00 & 1,85 & 0,15 & 0,05 & 0,51 & 0,09 & 0,11 & nd & nd & nd & nd & nd \\
\hline P 51 & montante & 2,70 & 0,30 & 9,75 & 0,25 & nd & nd & 0,08 & 0,04 & 0,02 & no & nd & nd & nd & 0,01 \\
\hline$P 49$ & meia-vertente & 35,0 & 0,90 & 0,75 & 1,50 & 0,11 & nd & 1,21 & 0,05 & nd & nd & nd & nd & nd & 0,01 \\
\hline PO4 & baixada & 25,0 & 3,00 & 9,05 & 1,70 & 0,10 & 0,07 & 1,18 & 0,06 & 0,10 & nd & nd & nd & nd & nd \\
\hline \multicolumn{2}{|c|}{ Limite de potabilidade $*$} & 200 & & & & 0,3 & 0,1 & 0,2 & $0, \%$ & & & 0,01 & 2 & 5 & 0,05 \\
\hline
\end{tabular}

* Portaria $n^{0} 1469$ de 29,12,2000 do Ministério da Saúde

$n d=$ não detectado 
Tabela 5.15 - Concentração de cátions na água subterrânea dos 15 poços monitorados

$2^{\circ}$ monitoramento (02.03.1998) - Resultados em mg/L

\begin{tabular}{|c|c|c|c|c|c|c|c|c|c|c|c|c|c|c|c|}
\hline Poço & Posição & $\mathrm{Na}^{+}$ & $\mathbf{K}^{+}$ & $\mathrm{Ca}^{2+}$ & $\mathrm{Mg}^{2+}$ & Fe total & $\mathrm{Mn}^{2+}$ & $\left.A\right|^{3+}$ & $\mathrm{Ba}^{2+}$ & $\mathrm{Sr}^{2+}$ & $\mathrm{Ni}^{2+}$ & $\mathbf{P b}^{2+}$ & $\mathrm{Cu}^{2+}$ & $\mathrm{Zn}^{2+}$ & Cr total \\
\hline P 26 & montante & 4,10 & 3,20 & 8,20 & 1,00 & 0,51 & 0,01 & 0,39 \% & 0,09 & 0,11 & nd & nd & nd & 0,01 & 0,01 \\
\hline P 29 & meia-vertente & 8,80 & 3,50 & 3,80 & 3,25 & nd & 0,02 & 0,03 & 0,73 & 0,06 & nd & nd & nd & nd & 0,01 \\
\hline$P 30$ & baixada & 20,0 & 2,20 & 28,8 & 1,05 & 0,07 & 0,10 & 0,03 & 0,26 & 0,21 & nd & nd & 0,01 & 0,02 & 0,02 \\
\hline P 20 & montante & 1,80 & 2,20 & 5,25 & 2,00 & 0,02 & nd & 0,03 & 0,10 & 0,08 & nd & nd & nd & 0,01 & nd \\
\hline P 21 & meia-vertente & 24,5 & 6,10 & 7,90 & 4,20 & nd & 0,12 & $0,35 \%$ & 1.11 & 0,11 & nd & nd. & nd & 0,03 & 0,01 \\
\hline P 19 & baixada & 35,0 & 20,0 & 63,5 & 4,75 & nd & 0,08 & 0,03 & 0,12 & 0,34 & nd & nd & nd & 0,02 & 0,02 \\
\hline P 44 & montante & 5,40 & 5,50 & 4,30 & 3,50 & 0,09 & 0,03 & 0,25 & 0,34 & 0,09 & nd & nd & nd & 0,01 & 0,01 \\
\hline P 45 & meia-vertente & 7,80 & 2,50 & 7,60 & 0,70 & 172 & 0,20 & 0,12 & 0,08 & 0,05 & nd & nd & nd & 0,01 & 0,02 \\
\hline P 46 & baixada & 10,4 & 2,70 & 1,25 & 0,30 & 0,03 & 0,03 & 0,20 & 0,12 & 0,01 & nd & nd & 0,01 & nd & 0,01 \\
\hline P 40 & montante & 2,10 & 0,60 & 13,45 & 0,10 & 0,17 & nd & 0.34 & 0,04 & 0,13 & nd & nd & 0,01 & 0,02 & 0,01 \\
\hline P 41 & meia-vertente & 28,0 & 9,80 & 17,10 & 1,55 & 0,04 & 0,02 & 5,09 & 0,10 & 0,28 & nd & nd & nd & 0,02 & 0,01 \\
\hline$P 42$ & baixada & 51,0 & 9,60 & 18,10 & 3,55 & 0,11 & 0,11 & 225 & 0,12 & 0,13 & nd & nd & nd & 0,01 & 0,02 \\
\hline P 51 & montante & 3,30 & 0,60 & 24,60 & 0,35 & 0,13 & nd & 0,08 & 0,03 & 0,28 & nd & nd & 0,01 & 0,03 & 0,01 \\
\hline P 49 & meia-vertente & 30,0 & 1,90 & 4,80 & 1,90 & 0,03 & 0,03 & 2,4 & 0,14 & 0,05 & nd & nd & nd & nd & 0,01 \\
\hline $\mathrm{PO4}$ & baixada & 38,0 & 5,00 & 13,80 & 2,25 & 0,04 & 0,11 & 6,68 & 0,10 & 0,09 & nd & nd & nd & 0,09 & 0,02 \\
\hline \multicolumn{2}{|c|}{ Córrego 1} & 10,2 & 4,10 & 10,3 & 2,30 & 3.16 & $1.0 \%$ & 0,86 & 0,06 & 0,09 & nd & nd & nd & nd & nd \\
\hline \multicolumn{2}{|c|}{ Córrego 2} & 6,8 & 3,40 & 6,05 & 1,45 & 4,22 & 0,28 & 7,08 & 0,09 & 0,08 & nd & nd & nd & nd & nd \\
\hline \multicolumn{2}{|c|}{ Limite de potabilidade * } & 200 & & & & 0.3 .3 & 0.1. & 02 & 0.7 & & & 0,01 & 2,0 & 5,8 & 0,05 \\
\hline
\end{tabular}

* Portaria $n^{\circ} 1469$ de 29.12.2000 do Ministério da Saúde

nd $=$ não detectado 
A Figura 5.15 mostra a variação das concentraçôes de sódio na aqua subterránea, nos 15 poços analisados em 02 periodos de monitoramento. As concentrações variaram de 1,60 mg/L (P20) até $51,0 \mathrm{mg} / \mathrm{L}$ (P42). As maiores concentrações ocorreram nas vertentes P20-P21-P19, P40-P41-P42 e P51P49-P04. Em todas as vertentes, a amplitude das concentrações de sódio seguiu o mesmo padrão do cloreto, aumentando de montante para jusante.

A Figura 5.16 mostra a variação das concentrações de potássio na água subterrânea, nos 15 poços analisados em 02 períodos de monitoramento. As concentrações variaram de $0,30 \mathrm{mg} / \mathrm{L}$ (P51) até $20,0 \mathrm{mg} / \mathrm{L}$ (P19). As maiores concentrações ocorreram nas vertentes P20-P21-P19 e P40P41-P42. Nestas vertentes e na vertente P51-P49-P04, a amplitude das concentrações de potássio seguiu o mesmo padrão do cloreto, aumentando de montante para jusante. Na vertente P44-P45-P46 a concentração de potássio foi maior no poço de montante, provavelmente influenciado pela presença da criação de cavalos no local, como discutido anteriormente.

A Figura 5.17 mostra a variação das concentrações de cálcio na água subterrânea, nos 15 poços analisados em 02 períodos de monitoramento. As concentrações variaram de $0,75 \mathrm{mg} / \mathrm{L}$ (P49) até $63,5 \mathrm{mg} / \mathrm{L}$ (P19). As maiores concentrações ocorreram nas vertentes P26-P29-P30 e P20-P21-P19. Nestas vertentes e na vertente P40-P41-P42, a amplitude das concentrações de cálcio seguiu o mesmo padrão do cloreto, aumentando de montante para jusante.

A Figura 5.18 mostra a variação das concentrações de magnésio na água subterrânea, nos 15 poços analisados em 02 períodos de monitoramento. As concentrações variaram de $0,10 \mathrm{mg} / \mathrm{L}$ (P40) até 4,80 mg/L (P19). A magnitude das concentrações de magnésio foi relativamente uniforme, ligeiramente maiores na vertente P20-P21-P19 e menos intensas na vertente P51-P49-P04. A amplitude das concentrações nestas vertentes e na vertente P40-P41-P42 seguiu o mesmo padrão do cloreto, aumentando de montante para jusante. $\mathrm{Na}$ vertente P44-P45-P46, a concentração de magnésio foi maior no poço de montante, provavelmente influenciado pela presença da criação de cavalos no local. 

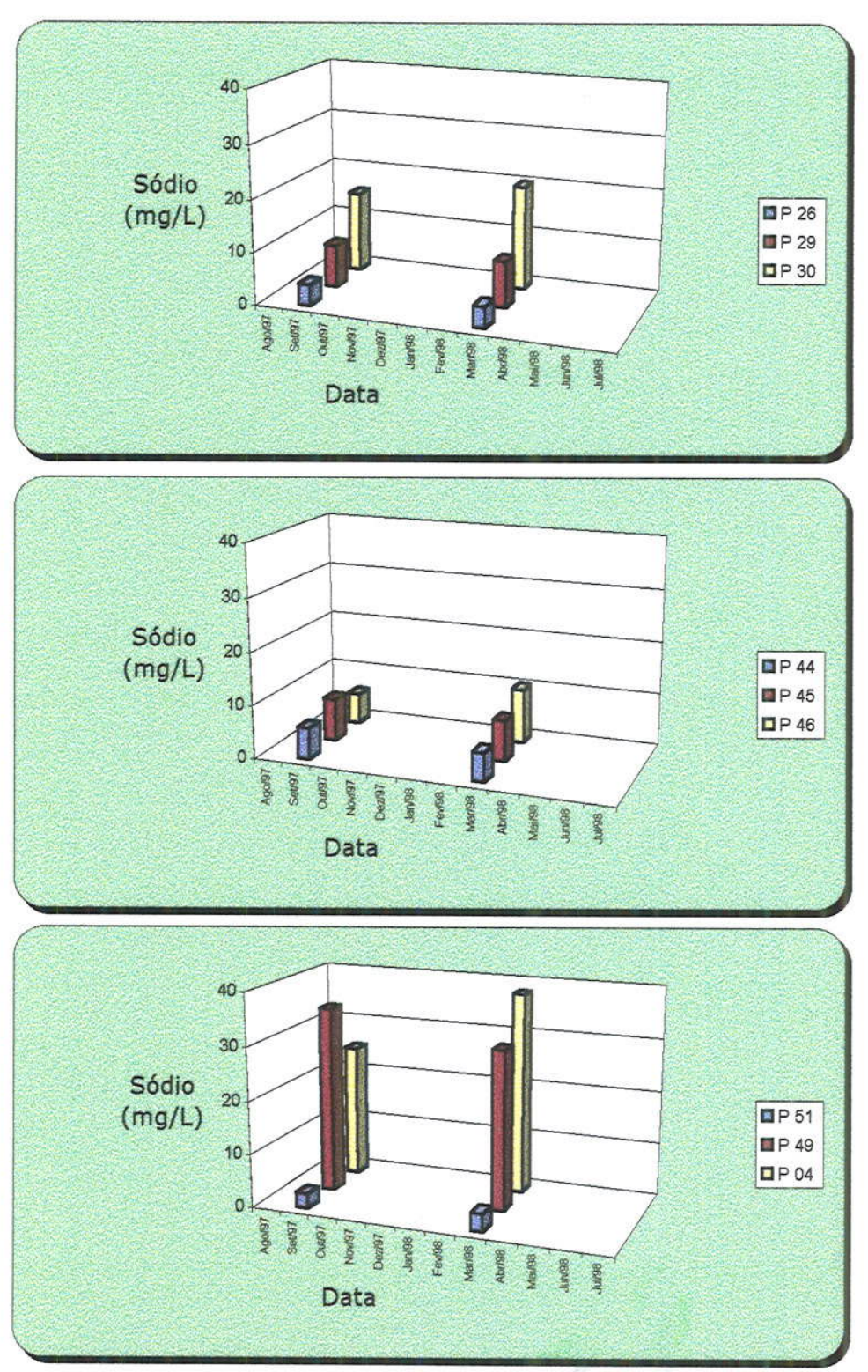
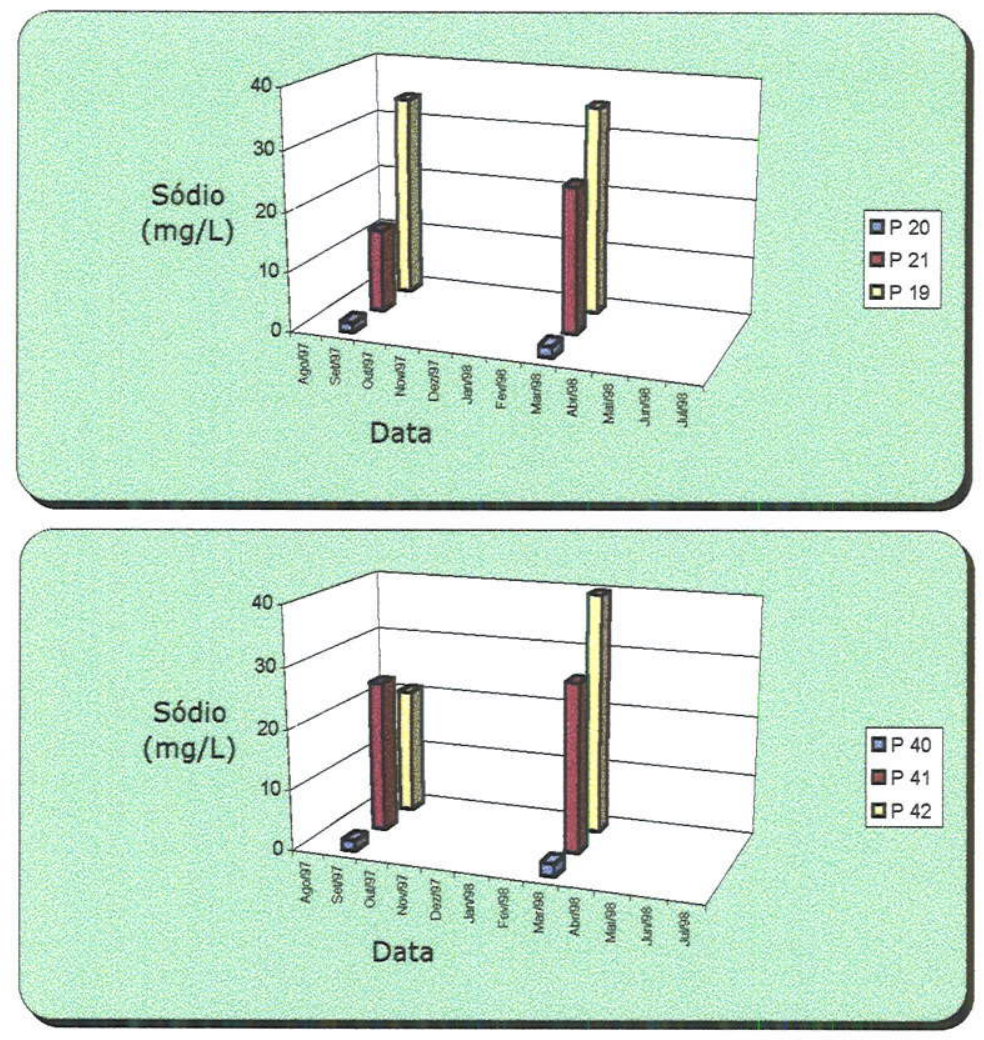

Figura 5.15 - Variação da concentração de sódio nos poços monitorados 

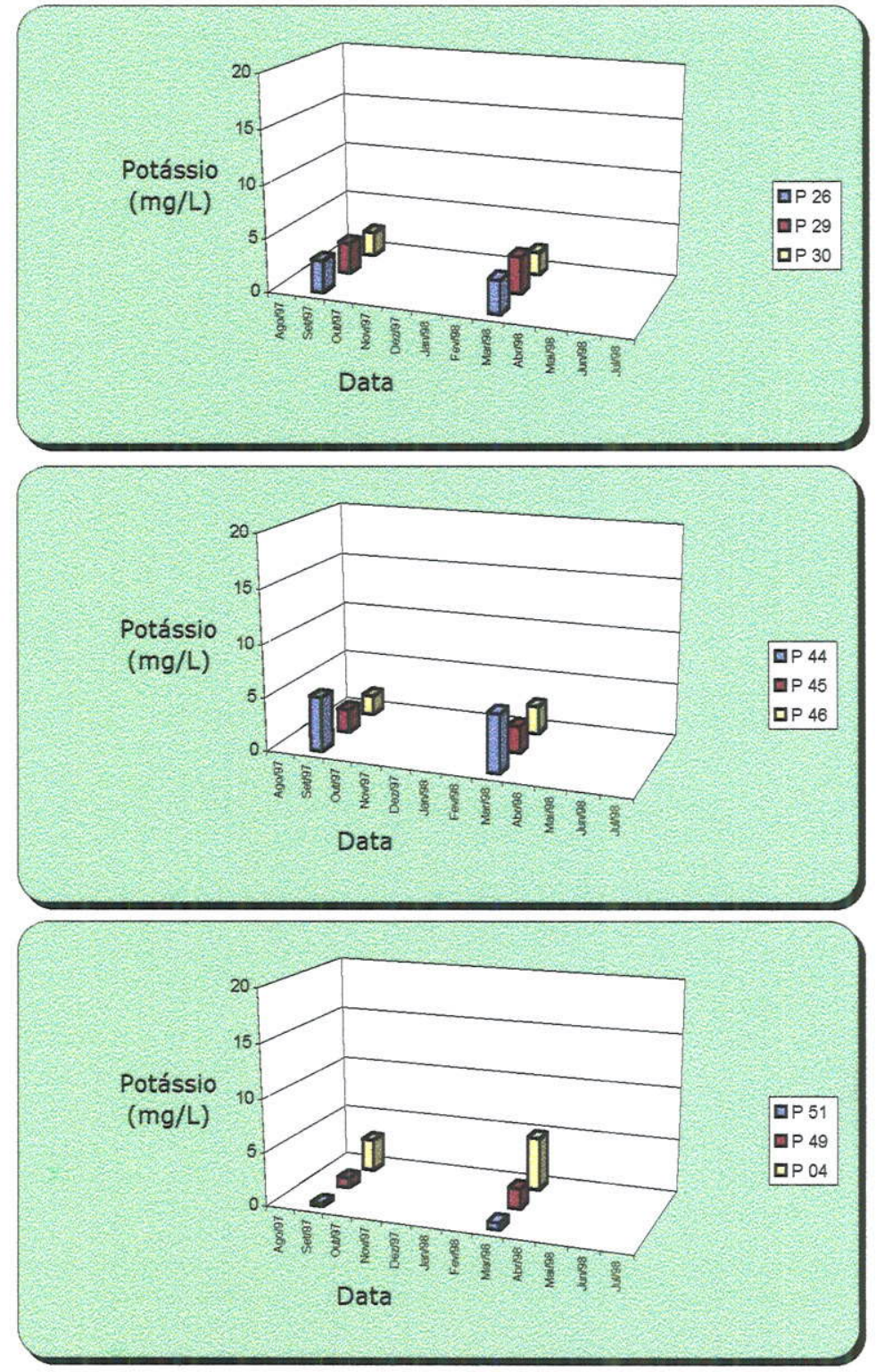
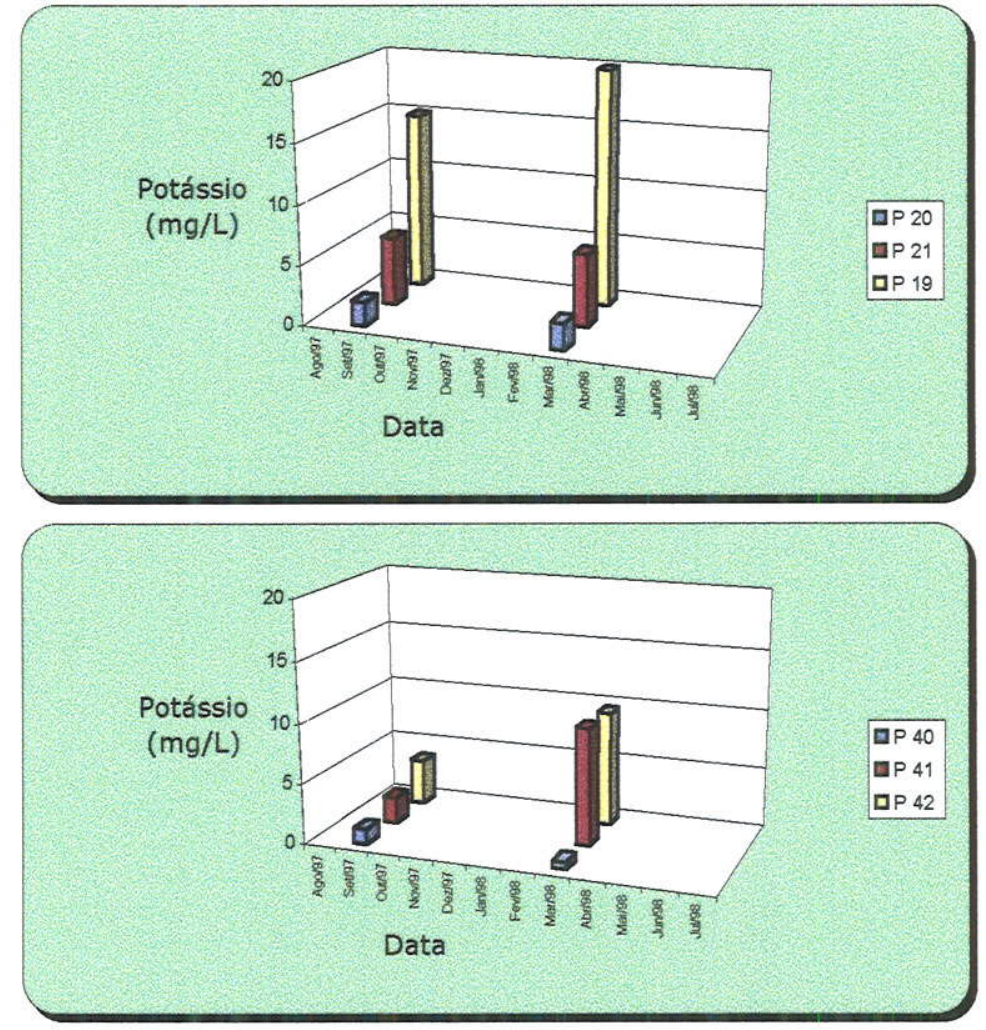

Figura 5.16 - Variação da concentração de potássio nos poços monitorados 

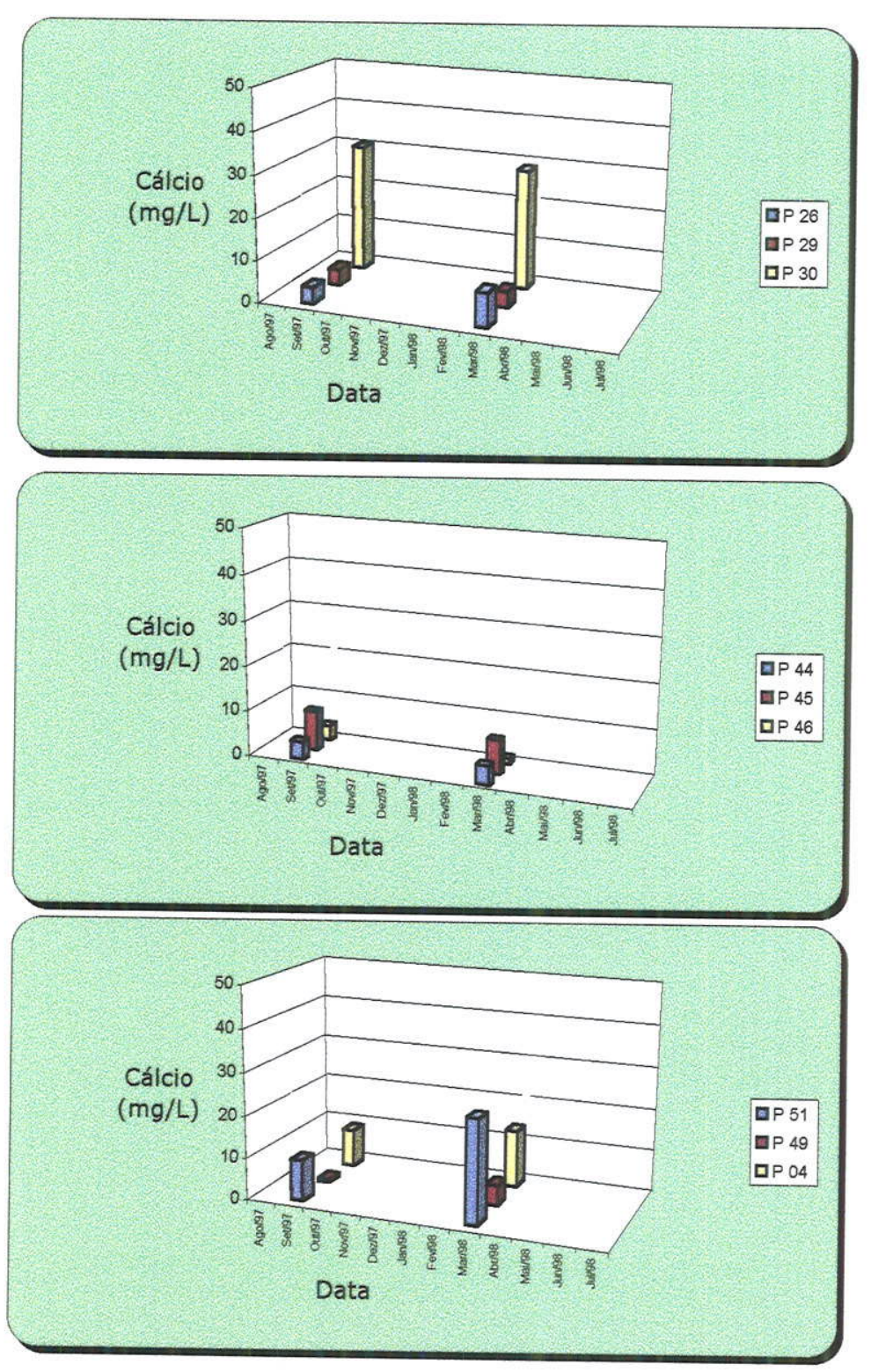
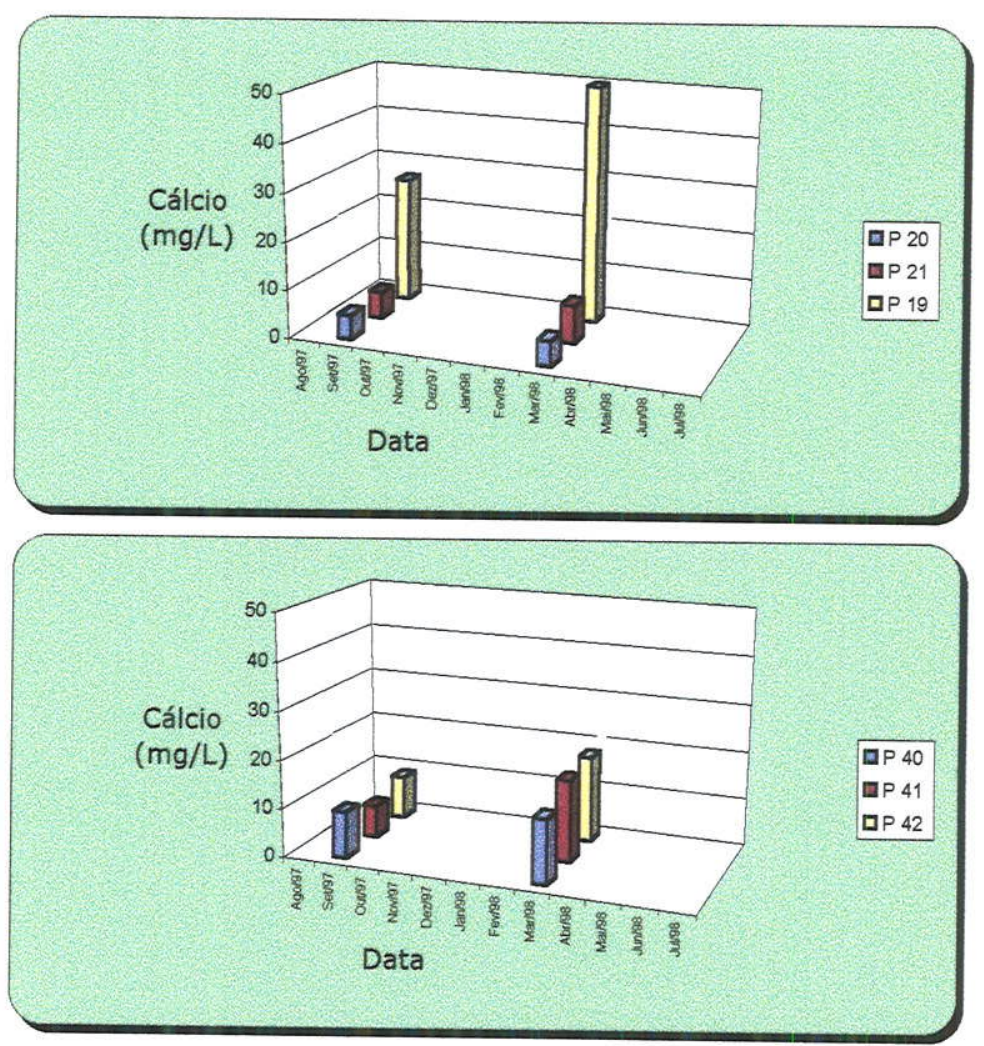

Figura 5.17 - Variação da concentração de cálcio nos poços monitorados 

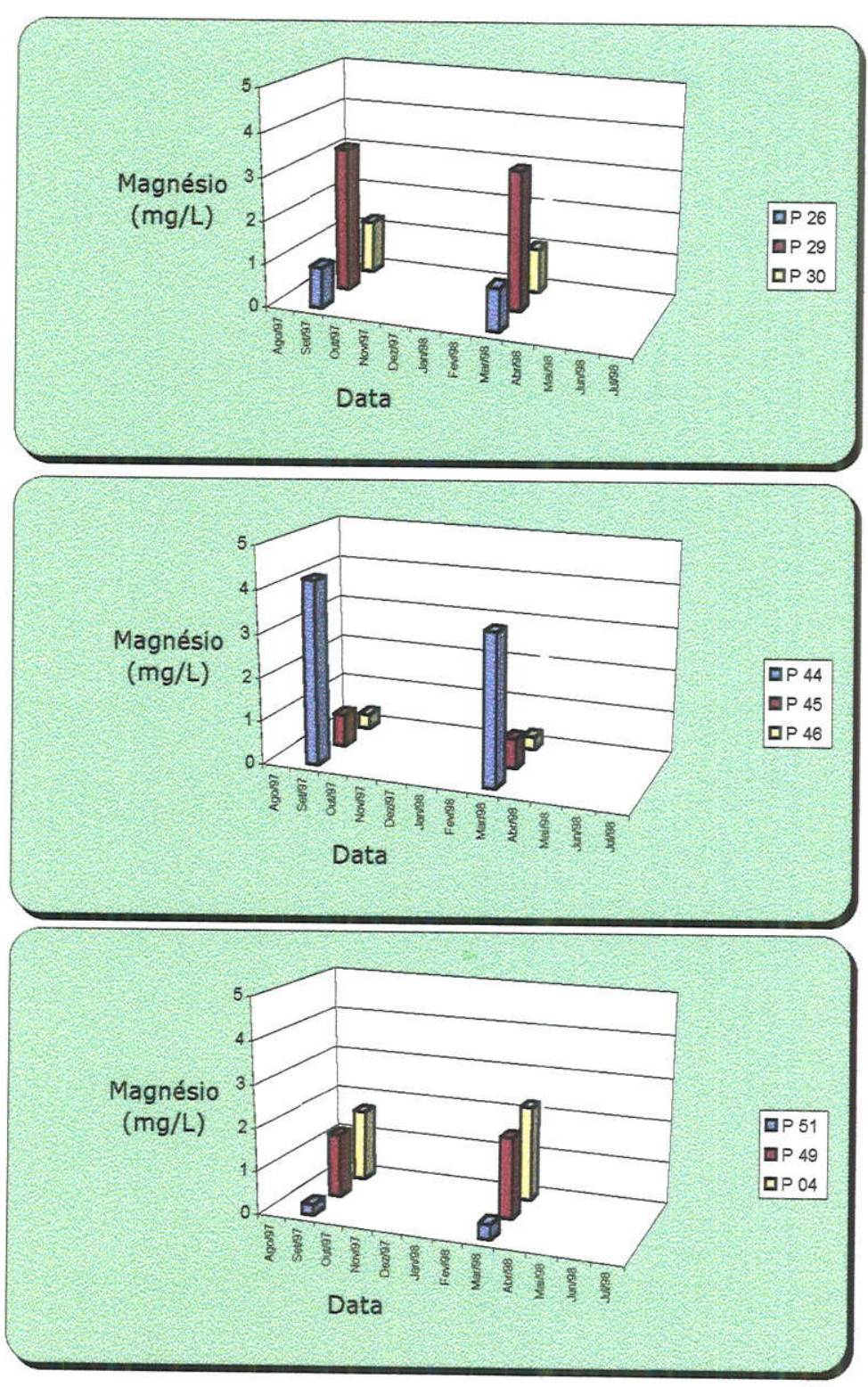
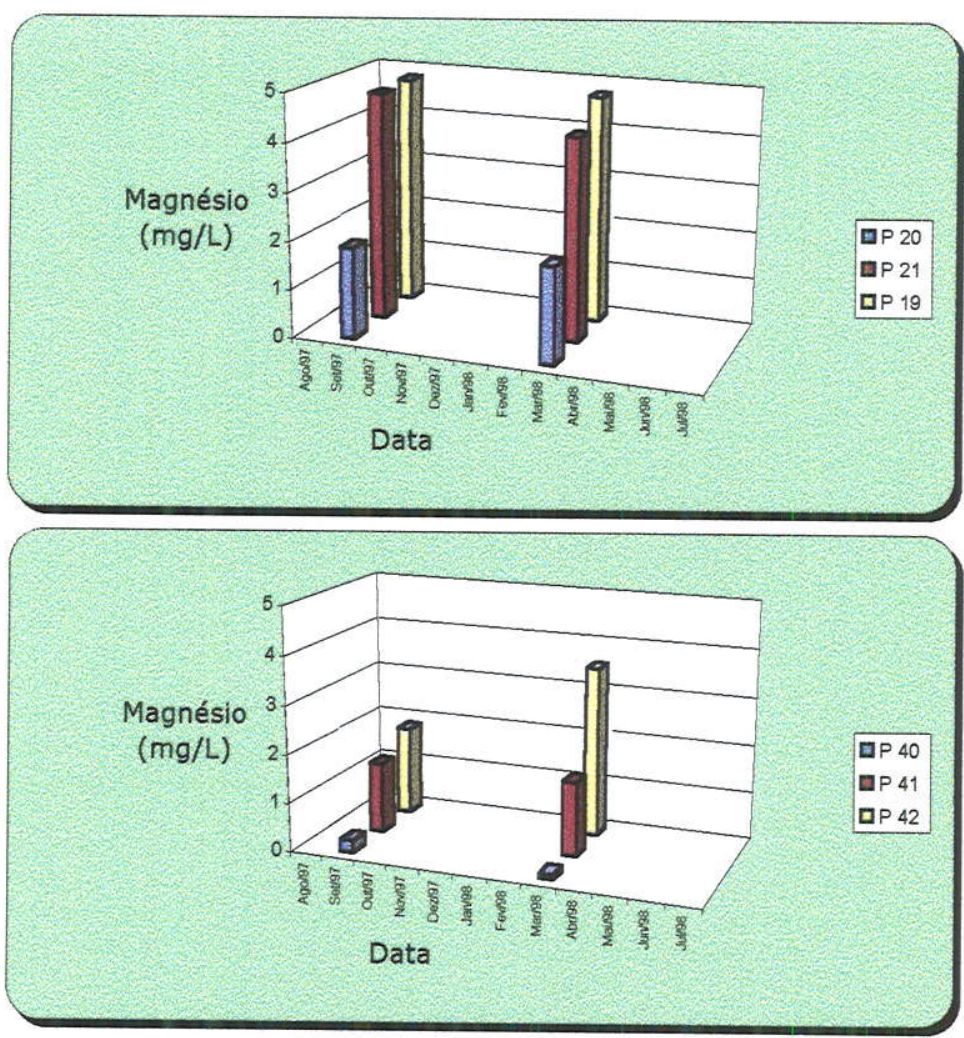

Figura 5.18 - Variação da concentração de magnésio nos poços monitorados 
A Figura 5.19 mostra a variação das concentrações de ferro total na água. subterrânea, nos 15 poços analisados em 02 períodos de monitoramento. As concentrações variaram de não detectado (poços 51, 19, 21 e 29) até $1,72 \mathrm{mg} / \mathrm{L}$ (P45). A concentração de ferro total ultrapassou o limite de potabilidade estabelecido pela Portaria $n^{\circ} 1.469$ do Ministério da Saúde $(0,30 \mathrm{mg} / \mathrm{L})$ em 16.09.1997, no P45 (0,88 mg/L), e em 02.03.1998, no PM $26(0,51 \mathrm{mg} / \mathrm{L})$ e no P45 $(1,72 \mathrm{mg} / \mathrm{L})$. A amplitude da variação de ferro total ao longo das vertentes não apresentou um padrão definido, cujas anomalias ocorreram de forma isolada naqueles poços.

A Figura 5.20 mostra a variação das concentrações de manganês na água subterrânea, nos 15 poços analisados em 02 períodos de monitoramento. As concentrações variaram de não detectado (poços 20, 26, 40,49 e 51) até $0,20 \mathrm{mg} / \mathrm{L}$ (P45). A concentrações de manganês ultrapassou o limite de potabilidade estabelecido pela Portaria $n^{\circ} 1.469$ do Ministério da Saúde $(0,10 \mathrm{mg} / \mathrm{L})$ no $P 45(0,20 \mathrm{mg} / \mathrm{L})$. A amplitude de variação da concentração de manganês ào longo das vertentes seguiu o padrão do ânion cloreto em todas as vertentes, com exceção da vertente 44-45-46, devido ao valor anômalo detectado no p45.

A Figura 5.21 mostra a variação das concentrações de alumínio na água subterrânea, nos 15 poços analisados em 02 períodos de monitoramento. As concentrações variaram de $0,03 \mathrm{mg} / \mathrm{L}$ (poços 19, 20, $29 \mathrm{e}$ 30) até $5,09 \mathrm{mg} / \mathrm{L}$ (P41): A concentrações de manganês ultrapassou o limite de potabilidade estabelecido pela Portaria $n^{\circ} 1.469$ do Ministério da Saúde $(0,20 \mathrm{mg} / \mathrm{L})$ em diversos poços, tanto no $1^{\circ}$ monitoramento (poços $04,21,40$, 41,42 e 49) quanto no $2^{\circ}$ monitoramento (poços $04,21,26,40,41,42$ e 49). A amplitude da variação de alumínio ao longo das vertentes não apresentou um padrão definido, em função das anomalias ocorridas.

A Figura $\mathbf{5 . 2 2}$ mostra a variação das concentrações de bário na água subterrânea, nos 15 poços analisados em 02 períodos de monitoramento. As concentrações variaram de $0,03 \mathrm{mg} / \mathrm{L}$ (P51) até $1,11 \mathrm{mg} / \mathrm{L}$ (P21). A concentrações de manganês ultrapassou o limite de potabilidade estabelecido pela Portaria $n^{\circ} 1.469$ do Ministério da Saúde $(0,70 \mathrm{mg} / \mathrm{L})$ no $\mathrm{P} 21$, nos 02 monitoramentos executados. 

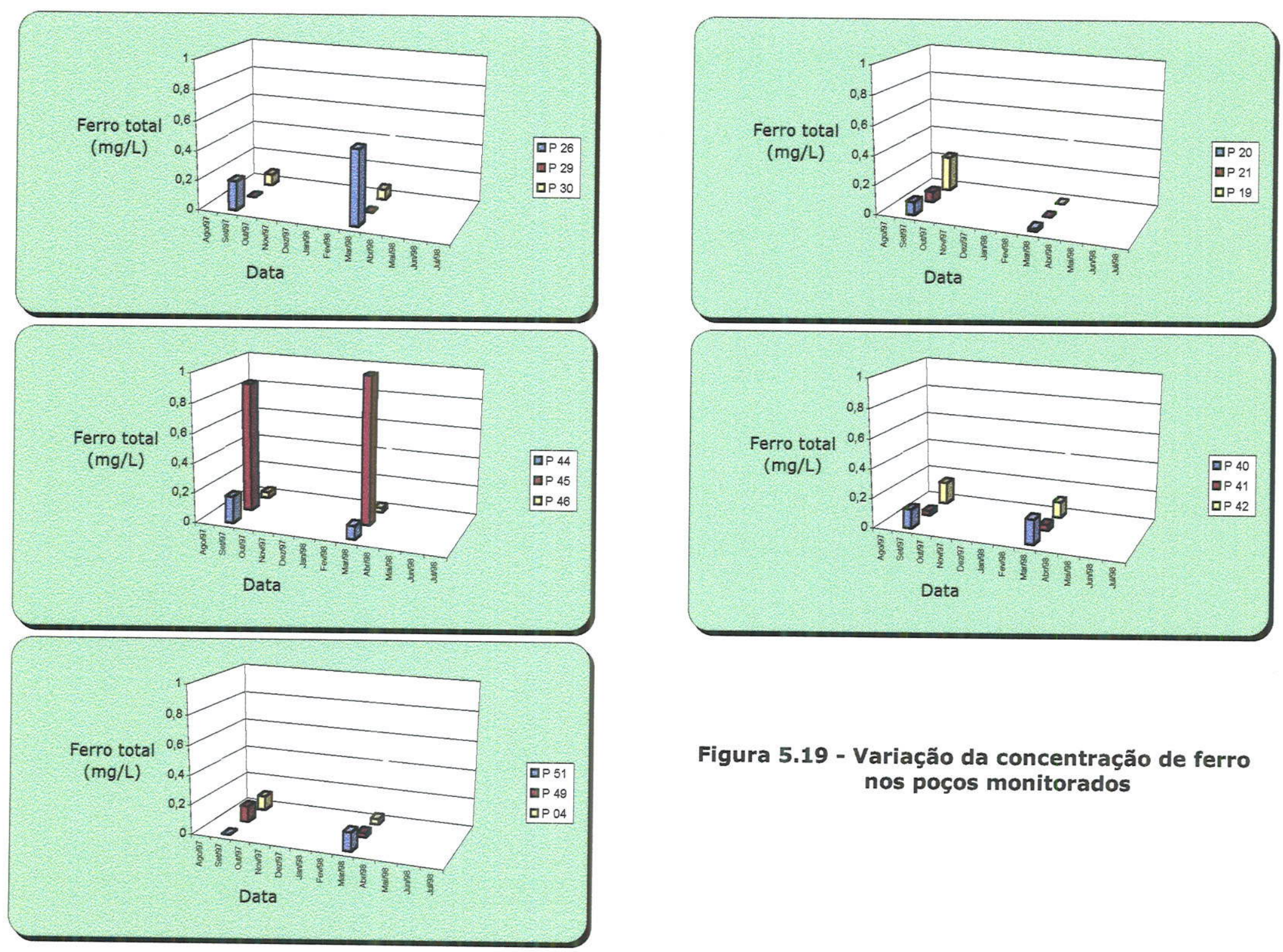

Figura 5.19 - Variação da concentração de ferro nos poços monitorados 

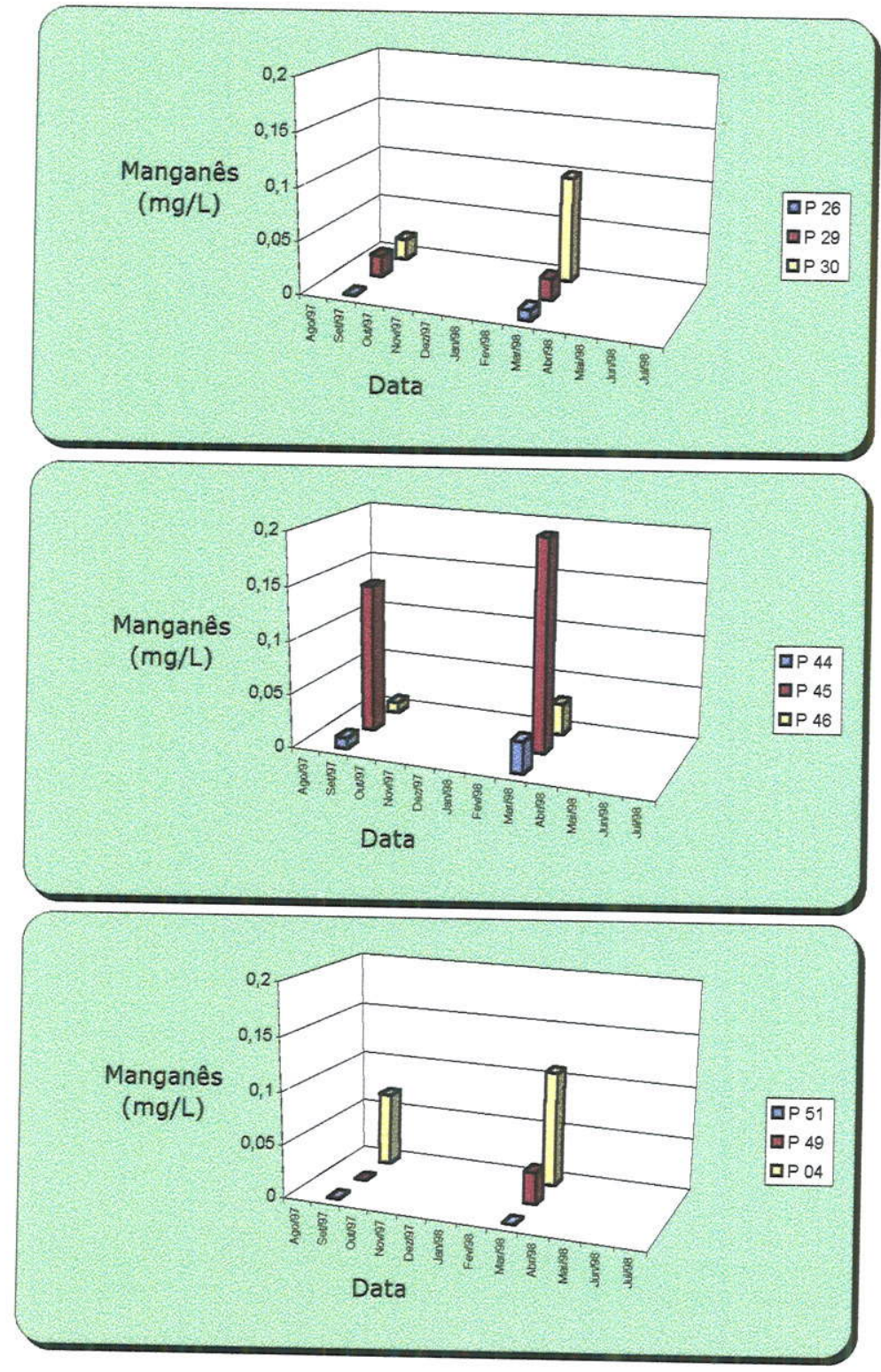
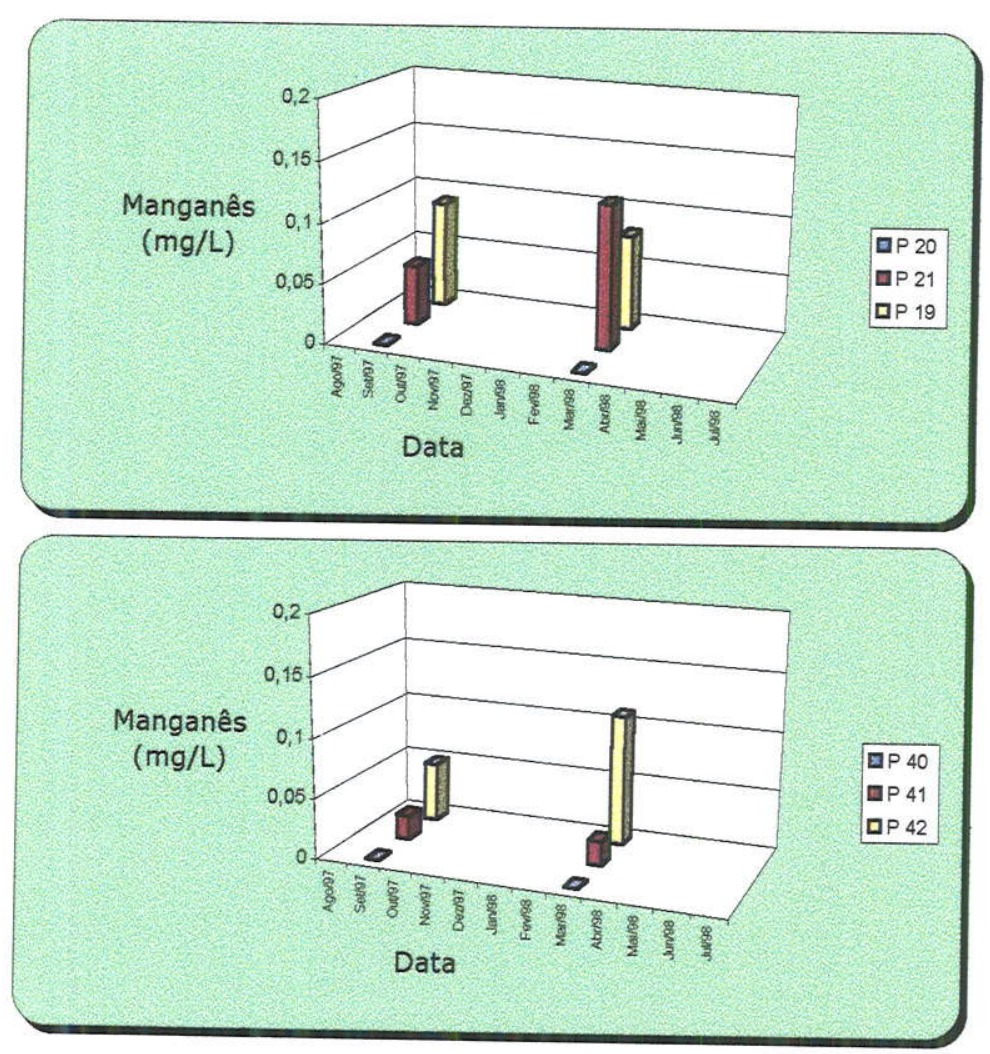

Figura 5.20 - Variação da concentração de manganês nos poços monitorados 

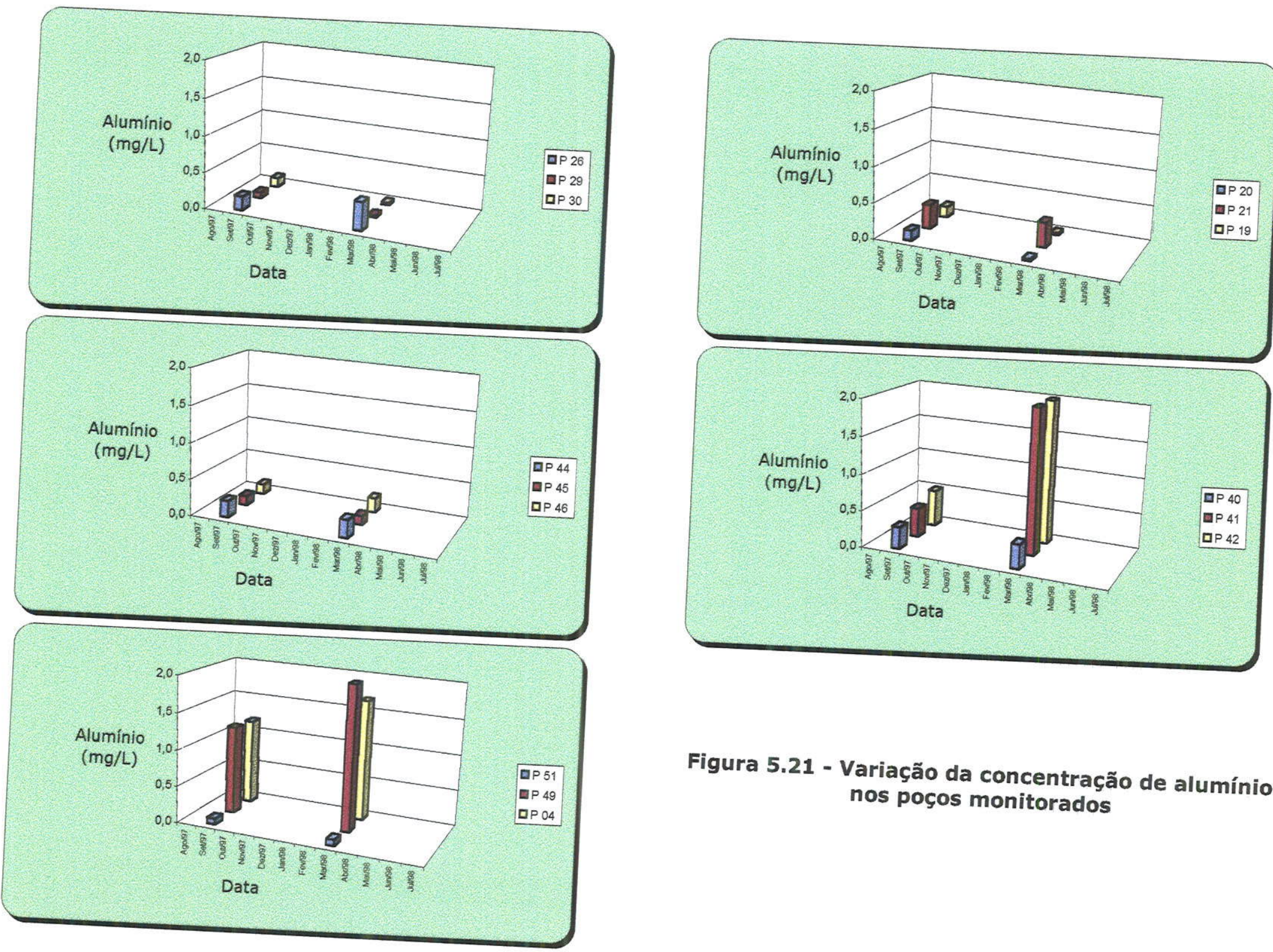

Figura 5.21 - Variação da concentração de alumínio nos poços monitorados 

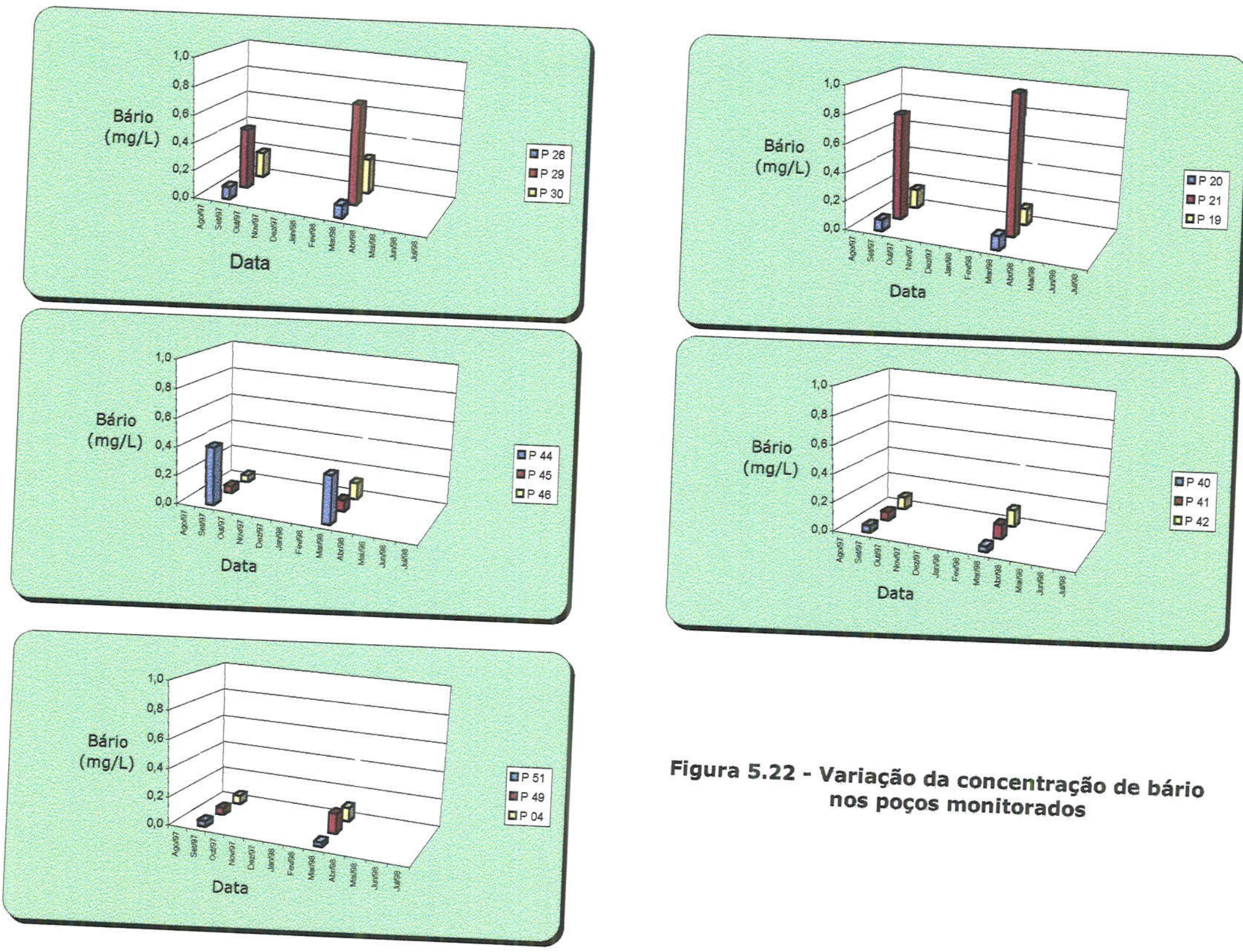
Figura 5.22 - Variação da concentração de bário
nos poços monitorados 
A amplitude da variação de alumínio ao longo das vertentes não apresentou um padrao dẹiniclo.

A Figura $\mathbf{5 . 2 3}$ mostra a variação das concentrações de estrôncio na água subterrânea, nos 15 poços analisados em 02 períodos de monitoramento. As concentrações variaram de não detectado (poços 46 e 49) até $0,34 \mathrm{mg} / \mathrm{L}$ (P19). A amplitude de variação da concentração de estrôncio ao longo das vertentes seguiu o padrão do ânion cloreto apenas nas vertentes P26-P29-P30 e P20-P21-P19. Nas demais vertentes, não houve padrão
definido.

Níquel e chumbo não foram detectados nas amostras de água subterrâneas analisadas. Cobre foi detectado num poço no primeiro monitoramento (P30) e em 04 poços no segundo monitoramento (P30, P40, P46 e P51), todos eles com $0,01 \mathrm{mg} / \mathrm{L}$, abaixo do limite de potabilidade estabelecido pela Portaria $n^{\circ} 1.469$ do Ministério da Saúde $(2,0 \mathrm{mg} / \mathrm{L})$.

O zinco foi detectado apenas no $2^{\circ}$ monitoramento na maioria dos poços, com concentração máxima de $0,09 \mathrm{mg} / \mathrm{L}$ ocorrida no $\mathrm{P04}$, abaixo, porém, do limite de potabilidade estabelecido pela Portaria $n^{\circ} 1.469$ do Ministério da Saúde $(5,0 \mathrm{mg} / \mathrm{L})$.

O cromo total ocorreu principalmente no $2^{\circ}$ monitoramento, em concentrações variáveis entre 0,01 e $0,02 \mathrm{mg} / \mathrm{L}$, abaixo do limite de potabilidade estabelecido pela Portaria $n^{\circ} 1.469$ do Ministério da Saúde $(0,05$
$\mathrm{mg} / \mathrm{L})$.

No segundo monitoramento químico, foram monitorados 02 pontos de córregos (mostrados na Figura 4.3), cujos resultados são apresentados na Tabela 5.15. Com exceção do ferro, manganês, alumínio, os demais cátions apresentaram, em geral, valores compatíveis com a média da concentração das águas subterrâneas. Estes 03 cátions citados apresentaram valores ligeiramente maiores que a média geral de concentração detectada nas águas subterrâneas.

Os laudos laboratoriais das análises químicas encontram-se no Anexo C. 

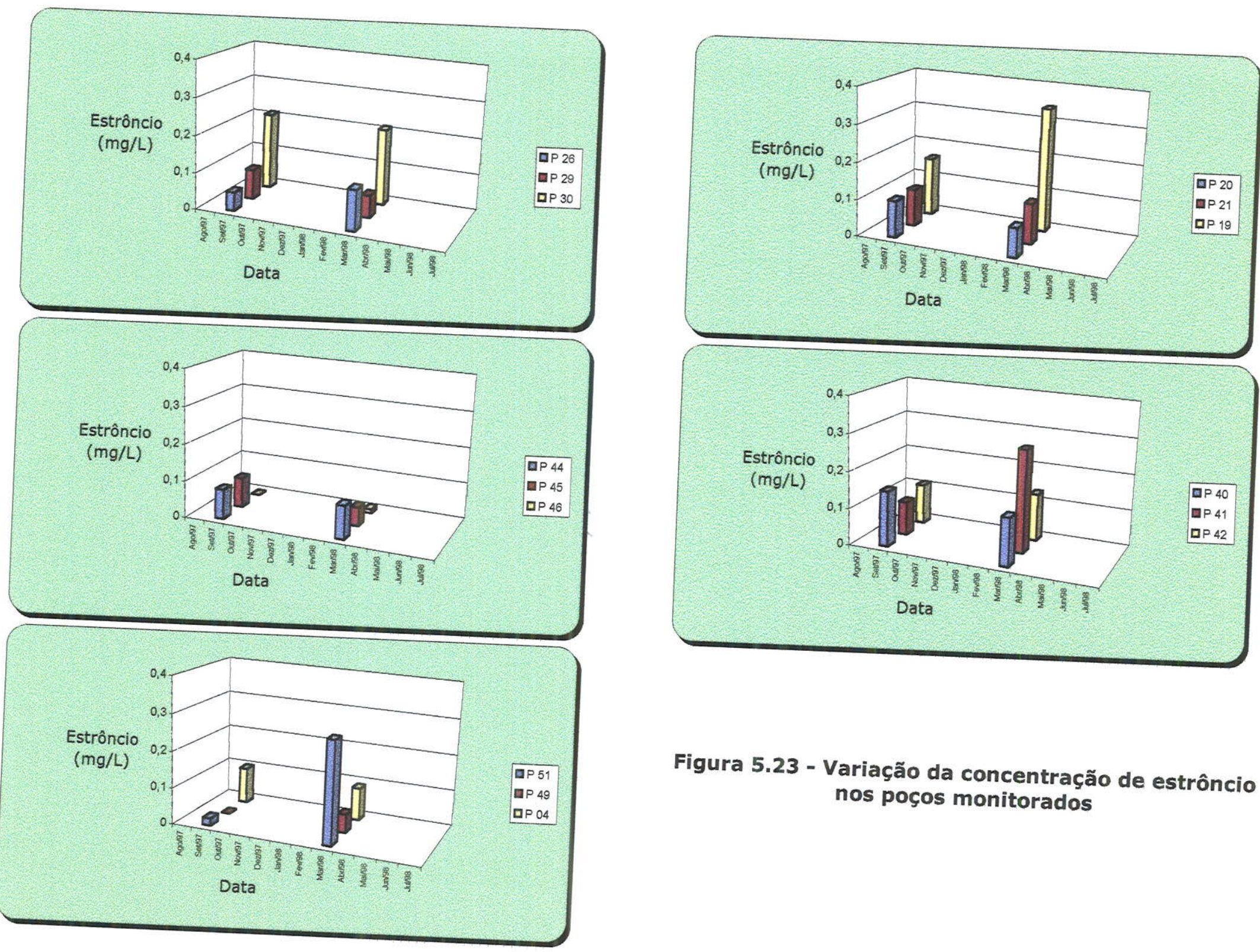
Figura 5.23 - Variação da concentração de estrôncio
nos poços monitorados 


\subsubsection{Análises físico-químicas}

A Tabela 5.16 mostra os valores de pH, Eh, condutividade elétrica $e$ temperatura da água subterrânea, medidos durante as campanhas de monitoramento químico dos 15 poços selecionados.

A Figura $\mathbf{5 . 2 4}$ mostra graficamente os valores de pH das amostras de água subterrânea coletadas nos 15 poços analisados durante o período de monitoramento químico. Nas vertentes dos poços 26-29-30 e 20-21-19, o pH teve um pequeno aumento de montante para jusante. Nas vertentes dos poços 40-41-42 e 51-49-04, ocorreu o inverso, o pH diminuiu de montante para jusante. $\mathrm{Na}$ vertente dos poços $44-45-46$, os valores foram mais regulares.

A Figura 5.25 mostra graficamente os valores de Eh das amostras de água subterrânea dos poços monitorados. Em geral, ouve diminuição dos valores de Eh ao longo das vertentes, podendo estar associado ao progressivo acréscimo de efluente de fossas de montante para jusante, diminuindo a disponibilidade de oxigênio na água, tornando o meio mais redutor.

A Figura 5.26 mostra graficamente os valores de condutividade elétrica (CE) das amostras de água subterrânea. Este parâmetro mostrou uma forte tendência de aumento ao longo das vertentes, associada ao aumento da concentração de íons dissolvidos na água subterrânea proveniente dos efluentes das fossas. O aumento da condutividade elétrica seguiu o mesmo padrão de variação do ânion cloreto, inclusive na vertente dos poços 44-45-46, cujo poço 44, na posição de montante, é influenciado localmente pela criação de cavalos nas suas proximidades (fezes animais).

A Tabela 5.17 mostra os valores de alcalinidade da água subterrânea, monitorada nos 15 poços durante todo o ano hidrológico. Os resultados são apresentados graficamente na Figura 5.27. O padrão de variação da alcalinidade ao longo das vertentes foi similar ao de $\mathrm{pH}$. Nas vertentes dos poços 26-29-30 e 20-21-19, o a alcalinidade aumentou de montante para jusante. Nas vertentes dos poços 40-41-42 e 51-49-04, ocorreu o inverso, a alcalinidade diminuiu de montante para jusante. Na vertente dos poços 44-4546 , os valores foram mais regulares. 
Tabela 5.16 - Resultados dos Parâmetros Físico-Químicos Analisados In Situ (15 Poços)

\begin{tabular}{|c|c|c|c|c|c|c|c|c|c|c|c|c|c|}
\hline \multirow[b]{2}{*}{ Poco } & \multirow[b]{2}{*}{ Posição } & \multicolumn{4}{|c|}{16.09 .1997} & \multicolumn{4}{|c|}{02.03 .1998} & \multicolumn{4}{|c|}{17.06 .1998} \\
\hline & & $\mathrm{pH}$ & Eh $(\mathrm{mv})$ & $\begin{array}{c}C E \\
(\mu S / \mathrm{cm})\end{array}$ & $\mathrm{T}\left({ }^{\circ} \mathrm{C}\right)$ & $\mathrm{pH}$ & Eh $(m v)$ & $\begin{array}{c}C E \\
(\mu / \mathrm{s} / \mathrm{Cn})\end{array}$ & $\mathrm{T}\left({ }^{\circ} \mathrm{C}\right)$ & $\mathrm{pH}$ & $\mathrm{Eh}(\mathrm{mv})$ & $\begin{array}{c}\mathrm{CE} \\
(\mu \mathrm{S} / \mathrm{cm})\end{array}$ & $r\left({ }^{\circ} c\right)$ \\
\hline$P 20$ & montante & 6,1 & 240 & 50 & 19,5 & 5,4 & 355 & 40 & 23,0 & 6,2 & 195 & 70 & 21,0 \\
\hline$P 21$ & intermediaria & 5,5 & 265 & 100 & 20.0 & 5,6 & 380 & 150 & 23,0 & 5,6 & 235 & 210 & 22,0 \\
\hline$P 19$ & jusante & 5,8 & 225 & 200 & 19,5 & 6,2 & 325 & 320 & 25,0 & 6,0 & 235 & 240 & 21,0 \\
\hline$P 44$ & montante & 5,3 & 290 & 50 & 20,0 & 5,9 & 210 & 70 & 22,0 & 5,5 & 245 & 100 & 21,0 \\
\hline$P 45$ & Intermediaria & 5,8 & 155 & 50 & 19,5 & 6,0 & 220 & 70 & 25,5 & 5,6 & 185 & 70 & 19,0 \\
\hline$P 46$ & jusante & 5,4 & 170 & 50 & 19,0 & 5,2 & 200 & 50 & 23,0 & 5,3 & 180 & 40 & 20,5 \\
\hline$P 40$ & montante & 6,6 & 330 & 50 & 19,0 & 6,2 & 280 & 60 & 21,5 & 5,9 & 260 & 70 & 20,5 \\
\hline$P 41$ & intermediária & 5,4 & 310 & 100 & 20,0 & 5,1 & 250 & 240 & 22,0 & 4,9 & 285 & 230 & 20,5 \\
\hline P 42 & jusante & 5,3 & 290 & 100 & $\pm 9,0$ & 4,9 & 270 & 330 & 22,0 & 5,1 & 270 & 280 & 21,0 \\
\hline$P 51$ & montante & 6,2 & 315 & 50 & 18,0 & 5,9 & 410 & 70 & 21,0 & 6,0 & 280 & 110 & 20,5 \\
\hline$P 49$ & intermediária & 4,4 & 375 & 100 & 19,5 & 4,3 & 474 & 150 & 22,5 & 4,8 & 375 & 430 & 20,0 \\
\hline$P 04$ & jusante & 4,7 & 360 & 100 & 19,0 & 4,7 & 195 & 230 & 23,5 & 4,9 & 345 & 220 & 20,5 \\
\hline$P 26$ & montante & 6,3 & 180 & 50 & 18,5 & 6,4 & 230 & 70 & 23,5 & 5,9 & 130 & 50 & 21,5 \\
\hline P. 29 & intermediária & 5,8 & 295 & 50 & 19,5 & 5,8 & 295 & 90 & 24,0 & 5,6 & 200 & 120 & 22,0 \\
\hline$P 30$ & jusante & 6,5 & 225 & 100 & 18,0 & 6,1 & 255 & 200 & 23,0 & 6,1 & 150 & 180 & 21,5 \\
\hline
\end{tabular}



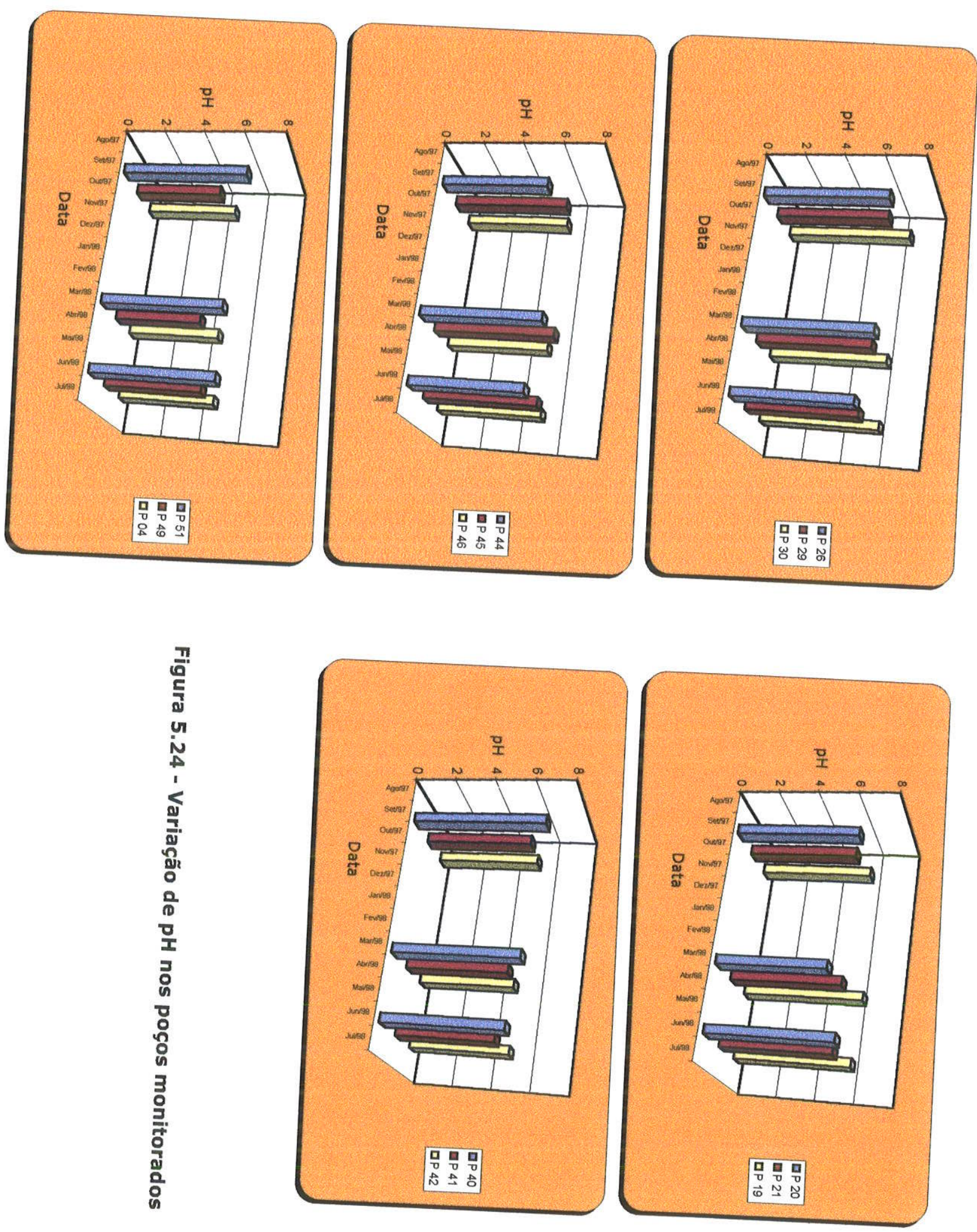

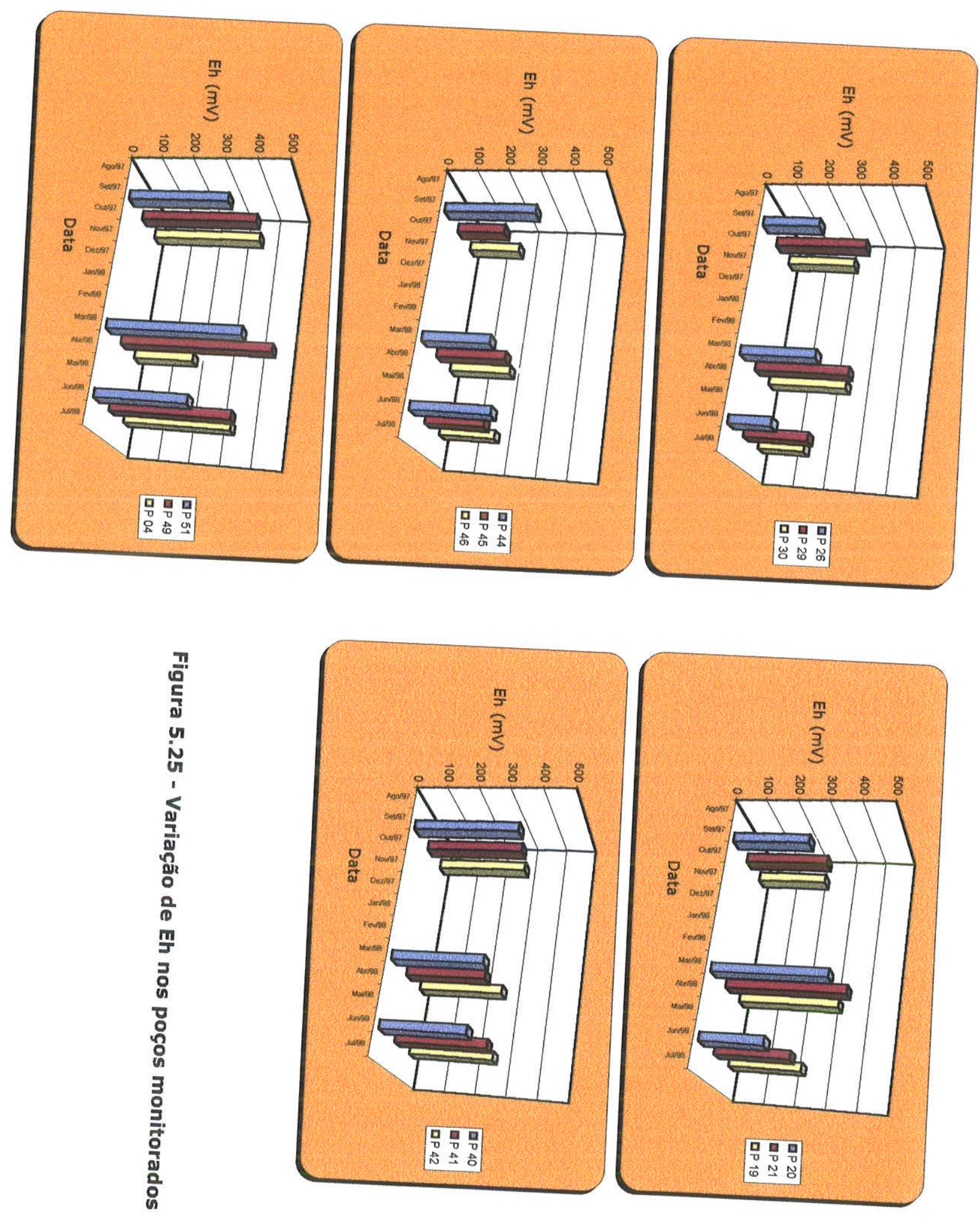

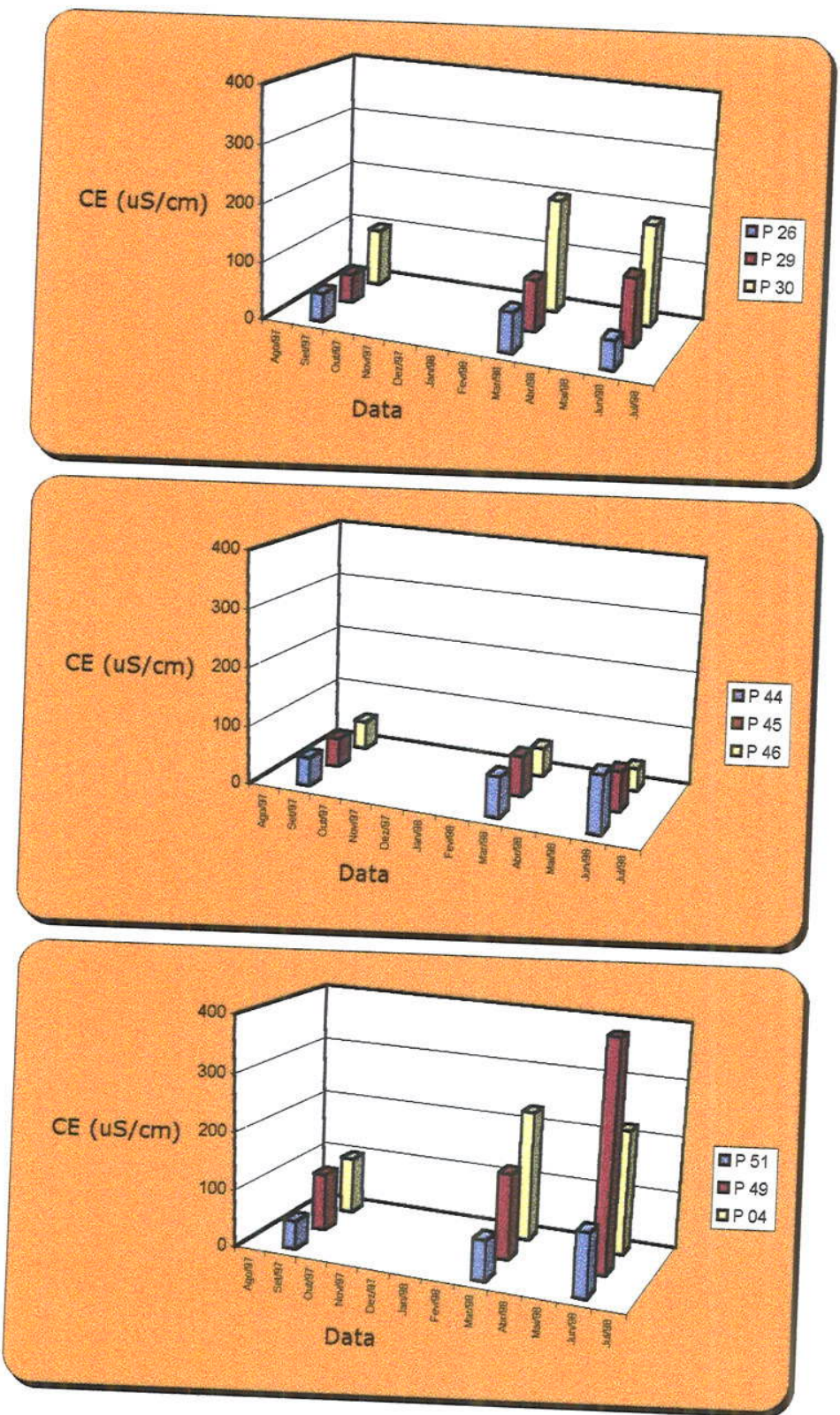
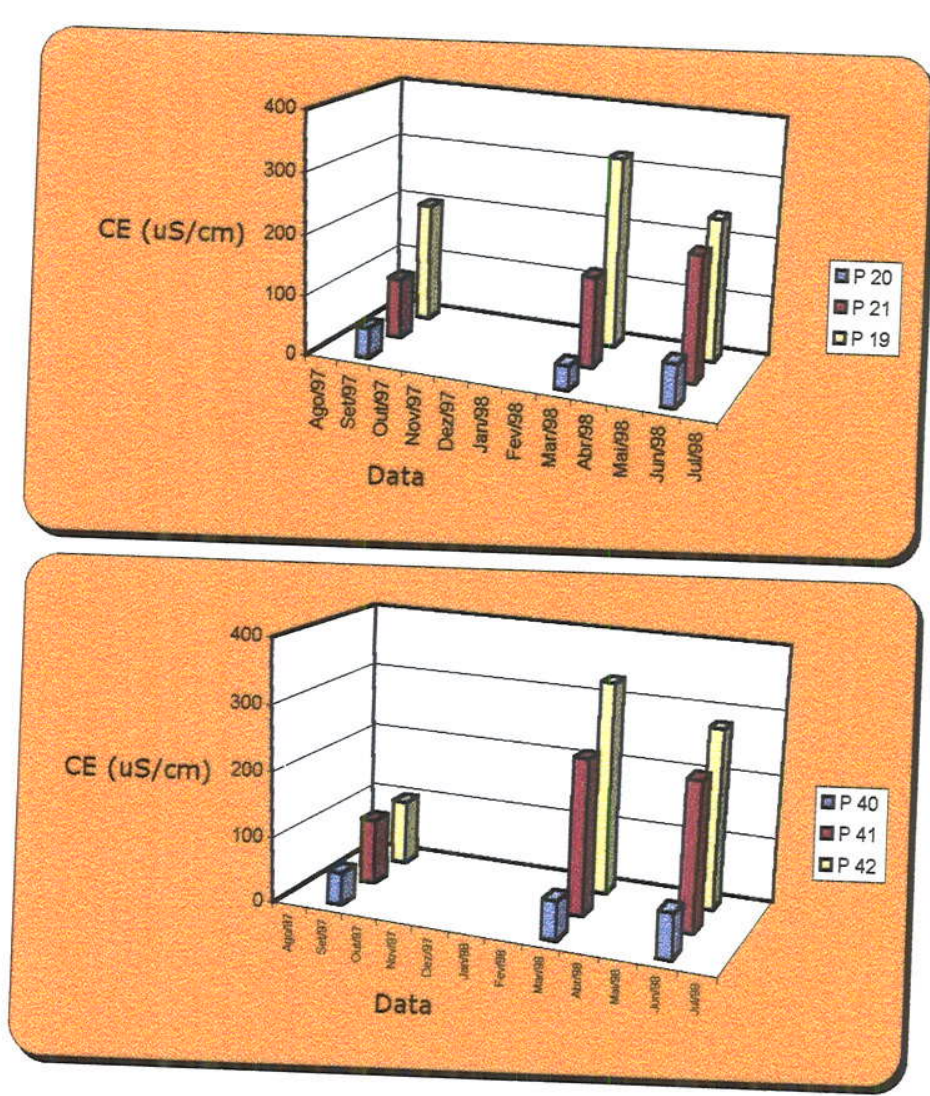

Figura 5.26 - Variação da condutividade elétrica nos poços monitorados 
Tabela 5.17 - Variação da alcalinidade nos 15 poços monitorados durante 01 ano hidrológico

\begin{tabular}{|c|c|c|c|c|c|c|c|c|c|c|c|}
\hline \multirow{2}{*}{ Poşo } & \multirow{2}{*}{ Posição } & \multicolumn{10}{|c|}{ ALCALINIDADE $\left[\mathrm{CaCO}_{3}\right] \mathrm{mg} / \mathrm{L}$} \\
\hline & & 20.08 .1997 & 16.09 .1997 & 27.10 .1997 & 09.02 .1998 & 02.03 .1998 & 23.03 .1998 & $16.0<:=98$ & 08.05 .1998 & 17.06 .1998 & 21.07 .1998 \\
\hline P 20 & montante & 25,02 & 25,02 & 25,02 & 20,02 & 15,01 & 15,01 & $25: 2$ & 20,02 & 15,01 & 20,02 \\
\hline P 21 & intermediária & 15,01 & 20,02 & 20,02 & 30,03 & 15,01 & 10,01 & $2 \equiv:=$ & 10,01 & 10,01 & 10,01 \\
\hline P 19 & jusante & 60,06 & 65,06 & 70,06 & 80,07 & 65,06 & 55,05 & $3 \pm: 23$ & 55,05 & 35,03 & 55,05 \\
\hline P 44 & montante & 10,01 & 10,01 & 12,51 & 20,02 & 10,01 & 10,01 & $12:=$ & 10,01 & 10,01 & 10,01 \\
\hline P 45 & intermediária & 30,03 & 35,03 & 55,05 & 20,02 & 20,02 & $\pm \Xi, 01$ & $1 \equiv \therefore$ & 25,02 & 15,01 & 15,01 \\
\hline P 46 & jusente & 15,01 & 20,02 & 10,01 & 10,01 & 5,00 & 10,01 & 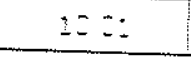 & 10,01 & 10,01 & 10,01 \\
\hline P 40 & montante & 30,03 & 25,02 & 50,05 & 45,04 & 25,02 & 30,03 & $30: 2$ & 30,03 & 25,02 & 30,03 \\
\hline P 41 & Intermediária & nd & nd & 15,01 & 10,01 & 10,01 & 20,02 & $\therefore \equiv:$ & 10,01 & 5,00 & 10,01 \\
\hline P 42 & jusante & 25,02 & 40,04 & 15,01 & 5,00 & 5,00 & $\$ 0,01$ & $\therefore 2 \therefore$ & 10,01 & 5,00 & 15,01 \\
\hline P 51 & montante & 40,04 & 50,05 & 50,05 & 30,03 & 35,03 & 45,04 & $3 \equiv .25$ & 35,03 & 35,03 & 45,04 \\
\hline P 49 & intermediária & nd & 5,00 & 12,51 & 5,00 & 10,01 & 10,01 & $\equiv-2$ & 5,00 & 5,00 & 5,00 \\
\hline P 04 & jusante & 15,01 & 10,01 & 10,01 & 5,00 & 5,00 & 10,01 & 5.20 & 10,01 & 5,00 & 10,01 \\
\hline P 26 & montante & 30,03 & 40,04 & 30,03 & 25,02 & 25,02 & 30,03 & $1 \Sigma_{i}: \therefore$ & 20,02 & 15,01 & 20,02 \\
\hline P 29 & intermediária & 15,01 & 25,02 & 30,03 & 20,02 & 15,01 & 10,01 & $10,2:$ & 10,01 & 15,01 & 10,01 \\
\hline P 30 & jusante & 70,06 & 65,06 & 95,09 & 40,04 & 45,04 & 30,03 & $35:=3$ & 35,03 & 40,04 & 45,04 \\
\hline
\end{tabular}



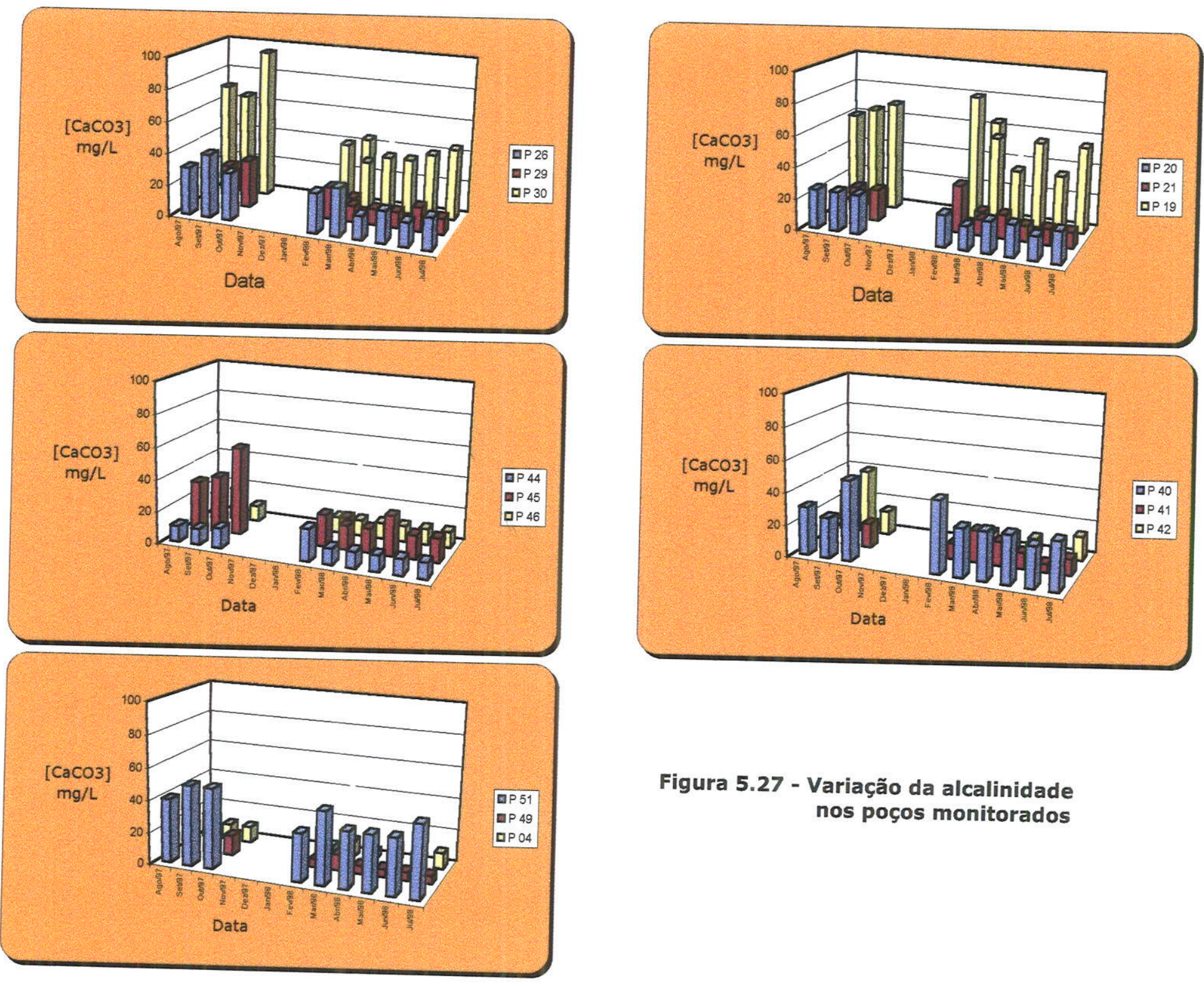

Figura 5.27 - Variação da alcalinidade nos poços monitorados 


\section{CONSIDERAÇõES FINAIS}

Para efeito de comparação dos resultados analíticos obtidos com as principais doenças que afetam a população do bairro, foi realizada uma pesquisa junto ao Posto de Saúde local (Unidade Básica de Saúde Recanto Mônica).

O Posto de Saúde entrou em funcionamento em dezembro de 1992 e atende principalmente pessoas que residem no bairro. Atende também pacientes de outras localidades, como Jardim Nápoles, Marengo, Vila Augusta, Piatã I e II, Pium, Jardim Marcelo, Jardim Novo Horizonte e Terra Prometida.

Diariamente, são atendidas, em média, 120 pessoas com consultas agendadas, 30 pessoas para inalação e 80 pessoas para aplicação de vacinas, curativos, medição de pressão e odontologia. Desse total, $90 \%$ das pessoas atendidas são crianças.

A principal dificuldade do levantamento das doenças que afetam a população local fol o fato do Posto de Saúde năo possuir registro estatístico das enfermidades diagnosticadas. Desta forma, a Chefe da Seção Administrativa da Unidade, Sra. Ana Lúcia Lima Costa, reportou verbalmente algumas considerações visando esclarecer estas lacunas.

Há uma nítida diferença nas doenças que ocorrem nos períodos de inverno e verão. No verão, a principal enfermidade é a diarréia de origem hídrica, causada por bactérias e protozoários (ameba e giárdia). No inverno ocorrem principalmente doenças respiratórias, com destaque para bronquite e pneumonia.

A diarréia, associada a vômito e, em alguns casos, desidratação, atinge principalmente as crianças, sendo menos freqüente em adultos. De 20 crianças atendidas, aproximadamente 15 apresentam estes sintomas.

As verminoses também são comum em crianças, principalmente ascaridíase e esquistossomose.

Dermatites também são freqüentes, inclusive a escabiose (sarna). Pacientes com outras doenças como hepatite, leptospirose, raiva e tuberculose são mais raros. Quando ocorrem, são encaminhados ao Hospital Municipal de 
Itaquequecetuba, pois o Posto de Saúde local não possui instrumentos e medicamentos específicos para tratamentos mais complexos.

Desta forma, há concordância entre a principal enfermidade manifestada pelos pacientes (diarréia) com os microorganismos detectados nas amostras de água subterrânea do bairro. A grande maioria dos poços investigados apresentou ocorrência de coliformes fecais e, em alguns casos, presença de cryptosporidium. Tais organismos, quando ingeridos, podem ocasionar diarréia de gravidade diversa.

Outra concordância é que, no verão, aumenta a concentração de microorganismos na água subterrânea e também aumentam os casos de diarréia na população local, sugerindo uma possível relação de causa e efeito.

Como as condições de saneamento básico do bairro Recanto Mônica são precárias e a população local sofre com a péssima qualidade da água que consomem, foram realizadas ações de saúde preventiva, com objetivo de minimizar a incidência de doenças de transmissão hidrica.

Neste sentido, em todas as casas cujos poços e fossas foram monitorados/cadastrados, os moradores foram orientados a realizar a desinfecção da água antes de consumi-la. Eles aprenderam a adicionar corretamente cloro (hipoclorito) na água, cerca de 02 gotas $(0,10 \mathrm{~mL}$ ) para cada litro d'água. Como foi identificado Cryptosporidium em diversos poços do bairro, fol sugerido que a água também fosse fervida durante 05 minutos, pois este protozoário é resistente à simples cloração. Para retirar partículas em suspensão, foi orientado que eles sempre filtrassem a água de consumo.

Além disso, foi falado sobre a importância da higiene pessoal como medida complementar na prevenção de doenças.

Várias pessoas pediram informações sobre aspectos construtivos de poços e fossas, além do melhor posicionamento desses elementos no terreno. Foram dadas dicas sobre proteção sanitária dos poços e limpeza de seu entorno, a fim de evitar a contaminação induzida pelos próprios usuários. Moradores que estavam com problemas em suas fossas ou que queriam construir novas fossas, foram orientados a procurar auxílio junto aos engenheiros da prefeitura para o planejamento e instalação das mesmas. 
Outra dica importante que a população recebeu foi sobre a forma e a freqüência correta de limpeza da caixa d'água, a fim de evitar a degradação, ainda maior, da água para consumo.

Foi realizada uma palestra para alunos da escola pública do bairro, onde foram reunidas crianças de diversas idades. Nesta palestra, foram transmitidas noções básicas das doenças causadas por diversos parasitas, a forma de transmissão e maneiras de prevenção, tudo em linguagem simples e direta. Foram dadas noções sobre meio ambiente (solo e água) e como o ser humano pode alterá-lo e contaminá-lo. No final, foi solicitado aos alunos que fizessem perguntas e que escrevessem ou desenhassem o que mais acharam importante na palestra.

Esta palestra foi idealizada pensando que as crianças têm maior facilidade de assimilar idéias e conceitos, além de transmiti-los aos pais e amigos, disseminando os conhecimentos adquiridos e colocando-os em prática.

Notamos, ao longo dos trabalhos de campo, que a população aos poucos se conscientizou dos problemas sanitários que viviam, cobrando do poder público municipal, através de representantes da Associação de Bairro, a extensão da rede coletora de esgoto e rede de distribuição de água tratada. A partir do segundo semestre de 1999, foram iniciadas as obras no bairro.

A principal rua que corta o bairro Recanto Mônica de norte a sul foi asfaltada, facilitando o tráfego de automóveis e do ônibus que circula no local. Neste período, também foram iniciadas obras de instalação de tubulações para a coleta do esgoto, primeiramente na zona sul do bairro. Hoje, a rede de esgoto já está instalada em toda esta região e em parte da zona norte. Da mesma forma, a rede de água foi estendida para o bairro, servindo grande parcela daquela comunidade.

Esta pesquisa serviu, entre outras coisas, para conscientizar as pessoas sobre a importância de consumir uma água limpa, somente conseguida através de condições sanitárias adequadas, que deve ser oferecida pela prefeitura através do saneamento básico, que é um direito da população e um dever das autoridades públicas. . 


\section{CONCLUSÕES}

A área estudada, bairro Recanto Mônica (Itaquaquecetuba, SP), até o término das atividades de campo, era desprovida de saneamento básico. A população utilizava poços rasos (cacimbas) para captação da água subterrânea para o uso doméstico e para consumo.

O esgoto sanitário produzido era destinado a fossas. A maioria das fossas cadastradas (95\%) é do tipo comum, sem critérios técnicos construtivos e com características sanitárias precárias. Deste total, cerca de $1 / 4$ são fossas negras, em contato direto com a água subterrânea.

O bairro é delimitado por córregos e, em algumas partes, por cristas topográficas (SW e SE), que serviram como condições de contorno hidrogeológico para delimitação física da região investigada. Foram delimitadas 05 principais vertentes, nas quais foram cadastrados 52 poços para definição dos sentidos de fluxo da água subterrânea local.

Durante 01 ano hidrológico, foram monitorados 15 poços (cacimbas) distribuídos regularmente no bairro, ao longo das 05 vertentes topográficas, para caracterizar a qualidade química e microbiológica da água subterrânea, influenciada pelos efluentes das fossas.

O aqüífero local é do tipo livre ou freático, constituído pelo solo residual de alteração (que localmente possui de 10 a $15 \mathrm{~m}$ de espessura) e pela rocha alterada. A condutividade hidráulica calculada é da ordem de $10^{-4} \mathrm{~cm} / \mathrm{s}$. A velocidade média da água subterrânea local é de $25 \mathrm{~m} / \mathrm{ano}$, variando de 10,3 a $38,6 \mathrm{~m} / a n$, em função de diferentes gradientes hidráulicos da área, associados à amplitude do relevo, que localmente varia de 700 a $800 \mathrm{~m}$ de altitude.

A sazonalidade (precipitação pluviométrica) e o posicionamento dos poços nas vertentes topográficas (influência de fossas) foram fatores que influenciaram a variação das concentrações das diversas substâncias dissolvidas na água subterrânea. Os aspectos sanitários e a densidade populacional do bairro Recanto Mônica, com características heterogêneas, também influenciaram as concentrações dos parâmetros monitorados. 
Em relação ao monitoramento microbiológico, foram detectadas elevadas concentrações de coliformes fecais e totais na água subterrânea (bactérias), além de colifagos (vírus indicativo de contaminação fecal) e Cryptosporidium (protozoário). Também foram detectados coliformes fecais e totais em elevadas concentrações em 02 córregos monitorados. Cryptosporidium foi detectado no material aquoso de 02 fossas analisadas, atestando que este protozoário provém do efluente das fossas e parasita o intestino humano. Não foi detectada a bactéria Salmonella nas amostras analisadas.

Entre os parâmetros microbiológicos analisados, os coliformes fecais apresentaram resultados mais seguros quanto à indicação de contaminação das amostras de água, quando comparados aos colifagos. Cryptosporidium foram analisados com menor freqüência, porém apresentaram resultados similares aos de coliformes fecais, embora a metodologia empregada na detecção daqueles protozoários tenha sido de caráter qualitativo.

Os resultados das análises de coliformes fecais também indicaram que os aspectos sanitários tiveram uma influência maior na qualidade da água subterrânea do que a densidade de fossas na mesma região. A região norte do bairro, apesar de menos povoada, apresentou indices de contaminação da água maiores do que observado na região sul, em função das características sanitárias mais precárias. A contaminação induzida, que pode ocorrer através da captação manual da água dos poços, também deve contribuir para diminuição da qualidade da água subterrânea.

Em relação às análises químicas, o ion mais importante que foi detectado nas amostras de água subterrânea é o nitrato, por ser prejudicial à saúde, principalmente às crianças, quando ingerido acima de $10 \mathrm{mg} / \mathrm{L}$. Foram obtidas concentrações muito elevadas, até $604,94 \mathrm{mg} / \mathrm{L}$.

A maioria dos cátions e dos ânions detectados nas amostras de água subterrânea aumentou de montante para jusante ao longo das vertentes, mostrando que ocorre progressivo aporte de solutos provenientes dos efluentes das fossas.

O nitrato, ao contrário da maioria das demais espécies químicas, teve um aumento de concentração até a região intermediária das vertentes e, em seguida, apresentou uma diminuição de concentração, detectada nos poços de 
jusante. O progressivo aporte de efluentes de fossas, faz com que a disponibilidade de oxigênio diminua (valores de Eh menores), deixando o meio aquoso mais redutor, o que desestabiliza o nitrato, transformando-o em outras espécies químicas, como o amônio e a amônia.

A incidência de doenças relacionadas à ingestão de água contaminada na população do bairro, de acordo com dados do Posto de Saúde local, é maior no verão. A principal enfermidade é a diarréia causada por parasitas, que, quando nào tratada, pode ocasionar complicaçöes mais sérias, como a desidratação. Nos meses mais frios e menos chuvosos, ocorrem, principalmente, doenças respiratórias (bronquite e pneumonia).

Estas observações confirmaram os resultados analíticos, principalmente em relação aos valores de coliformes fecais, que apresentaram uma marcante influência sazonal sobre os resultados.

Como medida de saúde preventiva, foi desenvolvido um programa informativo sobre métodos adequados de desinfecção da água para consumo junto à população do bairro Recanto Mônica, principalmente àquelas famílias que foram regularmente visitadas durante os trabalhos de campo para coleta de amostras de água. Também foi proferida uma palestra na escola pública do bairro, para crianças de diversas idades, onde foram discutidas questões sobre a pesquisa desenvolvida, métodos de saúde preventiva e higiene.

O efeito prático desta pesquisa foi a conscientização da população do bairro sobre as precárias condições de saneamento em que viviam, com influência direta sobre a saúde. Através de pressões cada vez maiores sobre o poder público, a partir do segundo semestre de 1999 foram iniciadas obras para estender a rede coletora de esgoto e de água tratada para a população local. Atualmente, grande parte das familias no bairro Recanto Mônica possui saneamento básico. 


\section{REFERÊNCIAS BIBLIOGRÁFICAS}

ABGE (1996). Ensaios de Permeabilidade em Solos. Associação Brasileira de Geologia de Engenharia. Boletim 04. $3^{\text {a }}$ edição. São Paulo (SP).

ABNT (1982). Construção e Instalação de Fossas Sépticas e Disposição dos Efluentes (NBR 7.229). Rio de Janeiro, $37 \mathrm{p}$.

Alloway, B.J \& Ayres, D.C (1997). Chemical Principles of Environimental Pollution. 2th edition. Chapman \& Hall. London, UK.

Appelo, C.A.J. \& Postma, D. (1993). Geochemistry, Groundwater and Pollution. A.A. Balkema, Rotterdam, 536 p.

Batalha, B.H.L. (1989). Fossa Séptica. Companhia de Tecnologia de Saneamento Ambiental. Série Manuais, $2^{\underline{a}}$ edição, $20 p$.

Bowen, R. (1986), Groundwater. $2^{\text {th }}$ edition. Elsevier Applied Science Publishers Ltd. 427 p. England.

Brasil - Associação Brasileira de Engenharia Sanitária (2000). ABES Informa, Ano 09, $n^{05} 11 / 12$, novembro/dezembro 2000, p.06.

Brasil - Ministério da Saúde (2000). Portaria No 1.469 de dezembro de 2000. Estabalece os Procedimentos e Responsabilidades Relativos ao Controle e Vigilância da Qualidade de Água para Consumo Humano e seu Padrão de Potabilidade.

Caicedo, N.L. (1996). Águas Subterrâneas: Contaminação e Remediação. In: XI seminário-Curso. Salvador, BA. 23 a 26 de outubro de 1996. Livro de Textos, p. 373-391.

Castro, V.L.L. (1994). Origem e Mecanismo de Poluição das Águas Subterrâneas na Área de Cidade Nova, Natal (RN). Dissertação de Mestrado. UFPE, Centro de Tecnologia. Pós-Graduação em Geociências. Recife (PE). 97p. 
Cavalcanti, M.A.M.P (1996). Impacto dos Sistemas de Saneamento "In Situ" nas Águas Subterrâneas nọ Bairro de Piratininga - Municipio de Niterói (RJ). Dissertação de Mestrado. IGC-USP.

Centro Panamericano de engenharia Sanitária (CEPIS, 2000). Evaluación de los Servicios de Agua Potable y Saniamento 2000 em las Americas. Homepage CEPIS (http://www.cepis.ops-oms.org/eswww/eva2000/ Brasil/cobertura/saneat.html).

CETESB (1991). Guia de Coleta e Preservação de Amostras de Água. Coordenação: Edmundo Garcia Agudo (et.al.). 150 p.

Domenico, P.A. \& Schwartz, F.W. (1990). Physical and Chemical Hydrogeology. John Wiley \& Sons, Inc. 824 p.

Espindola, R.S.; Batello, E.R.; Silva, A.L.B.; Gamba, R.C.; Ciapina, E.M.P.; Pellizari, V.H., Pacheco, A. (1997). Impactos Causados Pelos Sistemas de Saneamento In Situ às Águas Subterrâneas do Bairro Recanto Mônica, Itaquaquecetuba, SP. V Simpósio de Geologia do Sudeste. Atas. SBG/ABGE. Penedo, Itatiaia (RJ), 9 a 12 de dezembro de 1997, p. 258-260.

Fetter, C.W. (1994). Applied Hydrogeology. Prentice Hall, $3^{\text {rd }}$ Ed., 691p.

Fetter, C.W (1993). Contaminant Hydrogeology. McMillan, New York, 210 p.

Freeze, R.A. \& Cherry, J.A. (1979). Groundwater. Prentice-Hall, Inc., Englewood Cliffs, New Jersey, $604 \mathrm{p}$.

Foster, S.S.D., Ventura, M., Hirata, R.C.A. (1987). Contaminación de las Águas Subterráneas de Enfoque Ejecutivo de la Situación en América Latina y el Caribe en Relation com el Suministro de la Potable. CEPS, OPS/OMS. Lima, Peru. 
Gamba, R.C.; Ciapina, E.M.P.; Batello. E.R.; Espindola, R.S.; Silva, A.L.B.; Pacheco, A.; Pellizari, V.H. (1997a). Detecção de Oocistos de Cryptosporidium em Água Subterrânea Utilizada para Consumo no Bairro Recanto Mônica, Itaquaquecetuba, SP. V Simpósio de Geologia do Sudeste. Atas. SBG/ABGE. Penedo, Itatiaia (RJ), 9 a 12 de dezembro de 1997, p. 233 e 234.

Gamba, R.C.; Ciapina, E.M.P.; Batello. E.R.; Espindola, R.S.; Silva, A.L.B.; Pacheco, A.; Pellizari, V.H. (1997b). Detecção de Oocistos de Cryptosporidium em Água Subterrânea Utilizada para Consumo no Bairro Recanto Mônica, Itaquaquecetuba, SP. Congresso Brasileiro de Microbiologia Ambiental. Anais. Rio de Janeiro, setembro de 1997.

Gamba, R.C.; Ciapina, E.M.P.; Espindola, R.S.; Pacheco, A.; Pellizari, V.H. Detection of Cryptosporidium Oocysts in Groundwater for Consumption in Itaquaquecetuba, São Paulo, Brasil. Para publicação na Revista da Associação Brasileira de Microbiologia. No prelo.

Hypólito, R. (1996). Hidroquímica das Águas Naturais - Alcalinidade, Resíduo Solúvel e Determinação de CTC. Publicação Sob Forma de Apostila, Curso de Pós-Graduação. IGC-USP, $23 p$.

Hem, J.D. (1985). Study and Interpretation of the Chemical Characteristics of Natural Water. US Geol. Surv. Sater Supply Paper 2254, $3^{\text {rd }}$ ed., 264p.

IPT (1981a). Mapa Geomorfológico do Estado de São Paulo. Escala 1:100.000. Instituto de Pesquisas Tecnológicas.

IPT (1981b). Mapa Geológico do Estado de São Paulo. Escala 1:100.000. Instituto de Pesquisas Tecnológicas.

Melo, J.G de (1998). Fundamentos Hidrogeológicos para a Gestão Integrada de Recursos Hídricos na Região Metropolitana de Fortaleza, Estado do Ceará. Tese de Doutoramento. IGc-USP. 
Mawdsley, J.L.; Brooks, A.E.; Merry, R.J. (1996). Movement of the Protozoan pathogen Cryptosporidium parvum througt tree contrasting soil types. Biol Fertil Soll, 21:30-36 p. Springer-Verlag.

Miller, R.A. et al. (1986). Determination of the infectious dose of cryptosporidium and the influence of inoculum size on disease severity in a primate model. Abstract Annual Meeting of Am. Soc. Microbiol., Waxhington, D.C., 23-28 March, p. 49.

Sanchez, P. S. (1997). Microbiologia Ambiental. Apostila de Aula. Faculdade de Saúde Pública, Universidade de São Paulo. 216 p.

SEADE (1997). São Paulo em Dados. Dados do Município de Itaquaquecetuba. Fundação Sistema Estadual de Análise de Dados. Home Page: http:/www.seade.gov.br.

Wilhelm, S.R; Schiff, S.L. \& Cherry, J.A. (1994). Biogeochemical Evolution of Domestic Waste Water in Septic Systems: 1. Conceptual Model. Ground Water, vol. 32, no 6, p. 905-916. 
ANEXOS 
ANEXO A

DADOS GEOFÍSICOS PROCESSADOS PELO

PROGRAMA RESIST ${ }^{T M}$ 


\begin{tabular}{|c|c|c|c|}
\hline ESPACAMENTO & $\frac{\mathrm{HSS}}{\mathrm{HOD}}$ & $10^{1}$ DAD UADE & $\begin{array}{l}1 / 1 \\
\text { ERRO }\end{array}$ \\
\hline $\begin{array}{l}1.0 \\
1.5 \\
2.2 \\
3.2 \\
4.6 \\
6.8 \\
16.0 \\
14.7 \\
21.5 \\
31.6 \\
46.4 \\
68.1\end{array}$ & $\begin{array}{l}173.8 \\
186.9 \\
199.0 \\
236.7 \\
29.1 \\
373.9 \\
442.4 \\
472.6 \\
43.6 \\
336.7 \\
228.9 \\
163.7\end{array}$ & $\begin{array}{l}260.5 \\
241.3 \\
362.3 \\
362.7 \\
46.6 \\
51.1 \\
22.9 \\
32.9 \\
326.6\end{array}$ & $\begin{array}{r}-0.7 \\
-1.9 \\
-1.4 \\
3,1 \\
-3,8 \\
-7.5 \\
1.3 \\
4,6 \\
-3,2\end{array}$ \\
\hline
\end{tabular}

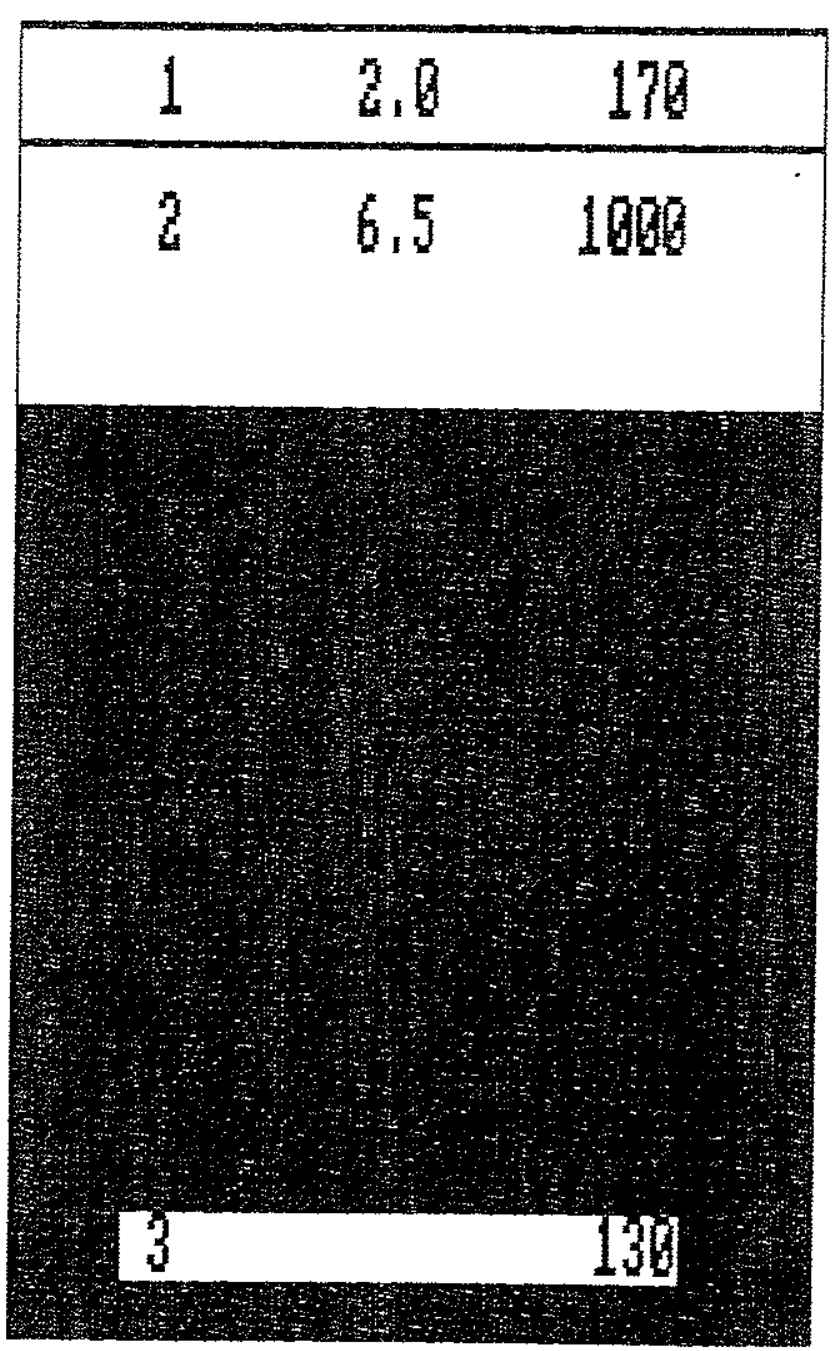




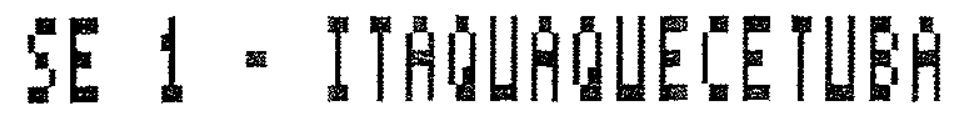

$-10000$

lon

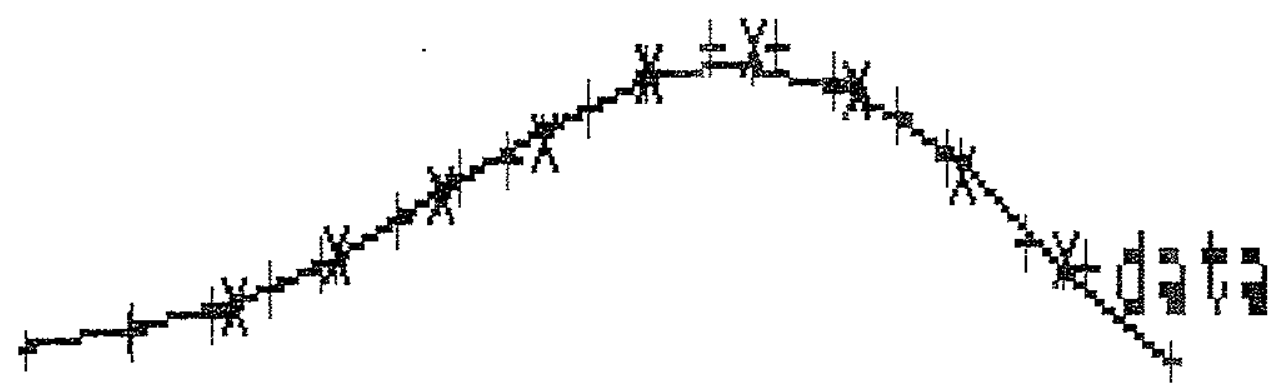




\section{SCHLLMBERGER HODELO DE SONDAGEM SE 2 - IIAQUARQUECETUBA}

ESPACAMENTO REISTIUIDADE DOLO DRO
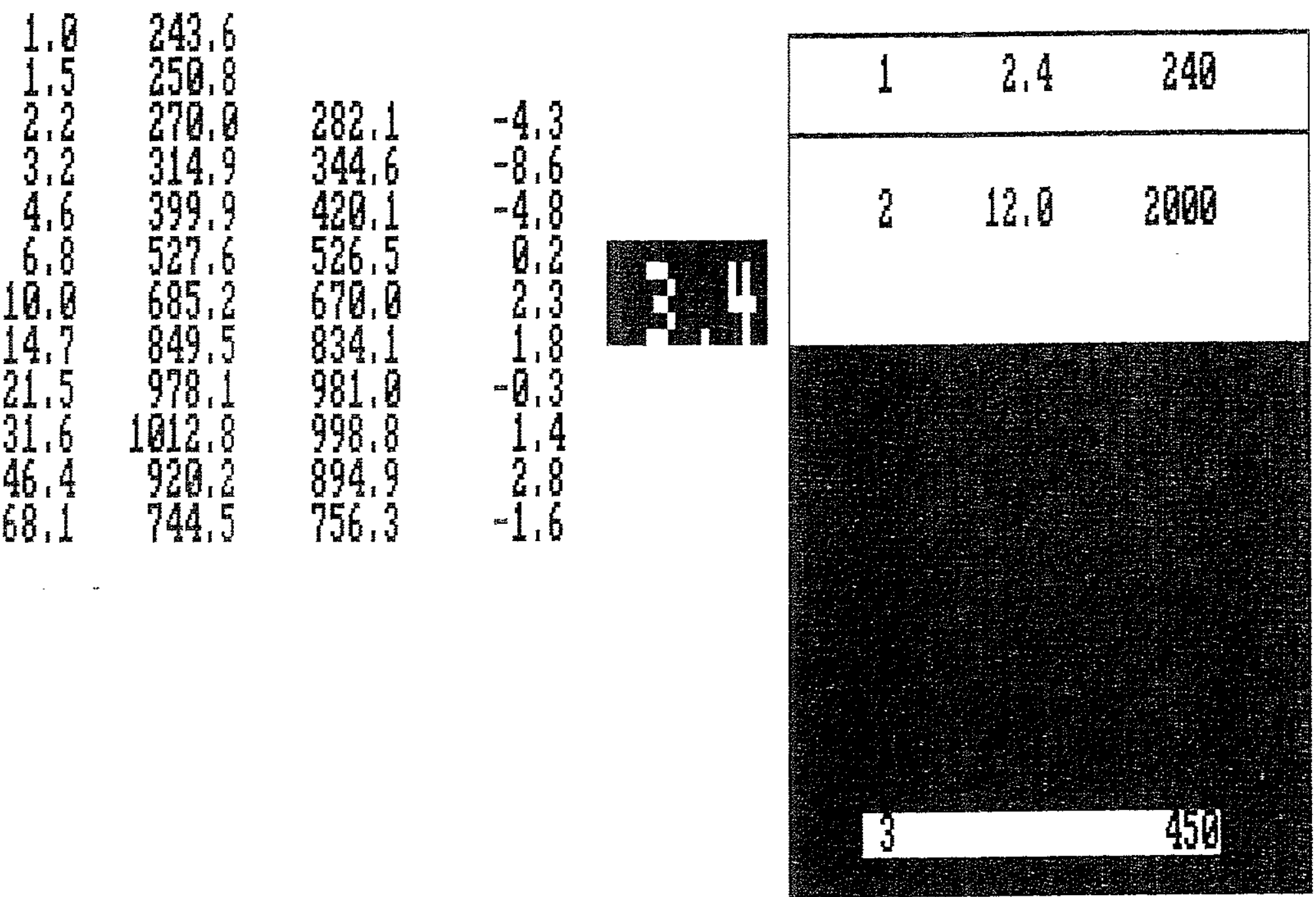


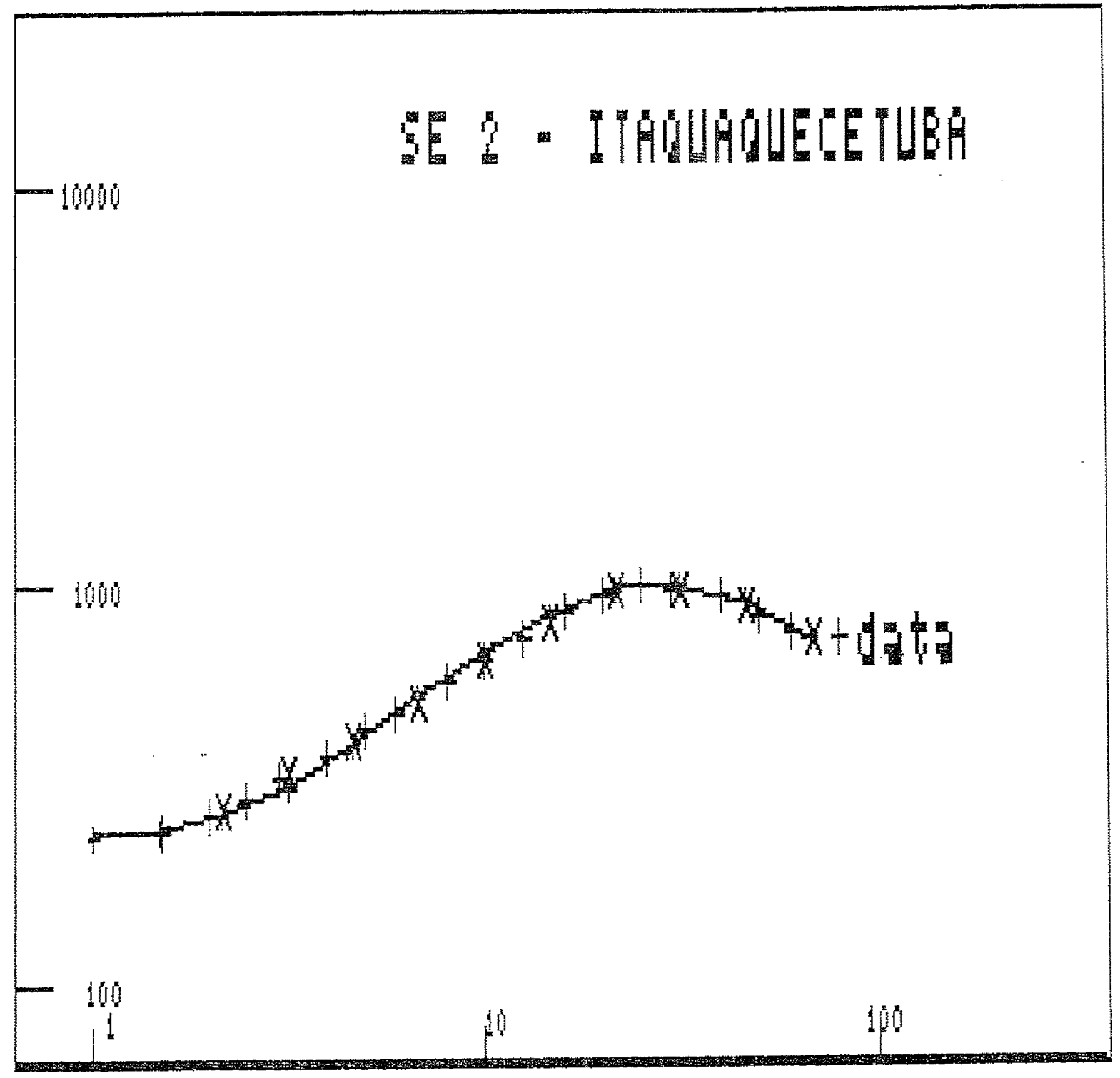




\section{SCHLUMBERGER HODELO DE SONDAGEM SE 3 - ITAQUAQLECETUBA}
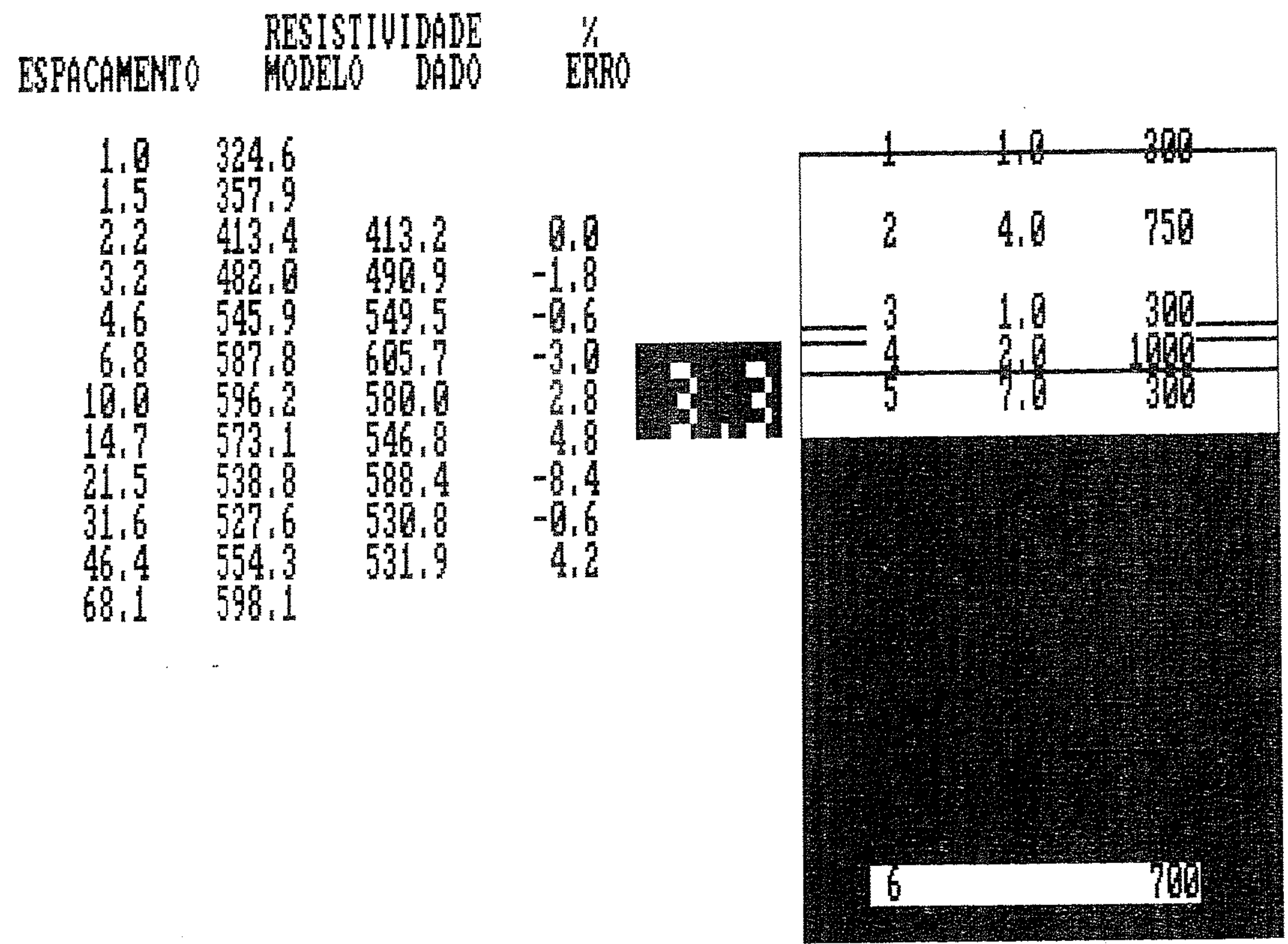


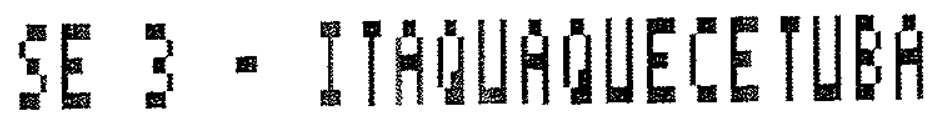

$-3000$

1000

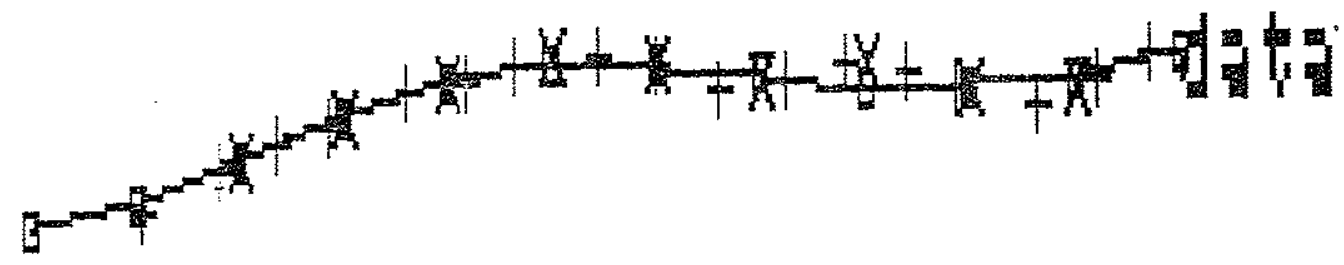

10i0 


\section{SCHLLMBERCER HODELO DE SONDAGEM SE 4 - ITAOUAQUECETUBA}

ESPCAMEMIO REISTIUIDADE DEL DADO ERRO

$1.0 \quad 1085.3$

$1.5 \quad 1658.3$

$2.2 \quad 92,9$

$3.2 \quad 868,6$

$4.6 \quad 765.4$

$6.8 \quad 577.4$

$10.6 \quad 52.2$

$14.7 \quad 477.8$

$21.5 \quad 463.5$

$31,6 \quad 326,5$

$46.4 \quad 288.9$

68.1285 .0

$1010.3-1.7$

$844,32.9$

625.612 .9

$562,4 \quad 2.7$

$559.0 \quad-5,4$

503

305

314.4

300.2

$-51$

2,1

3.8

$-3.8$

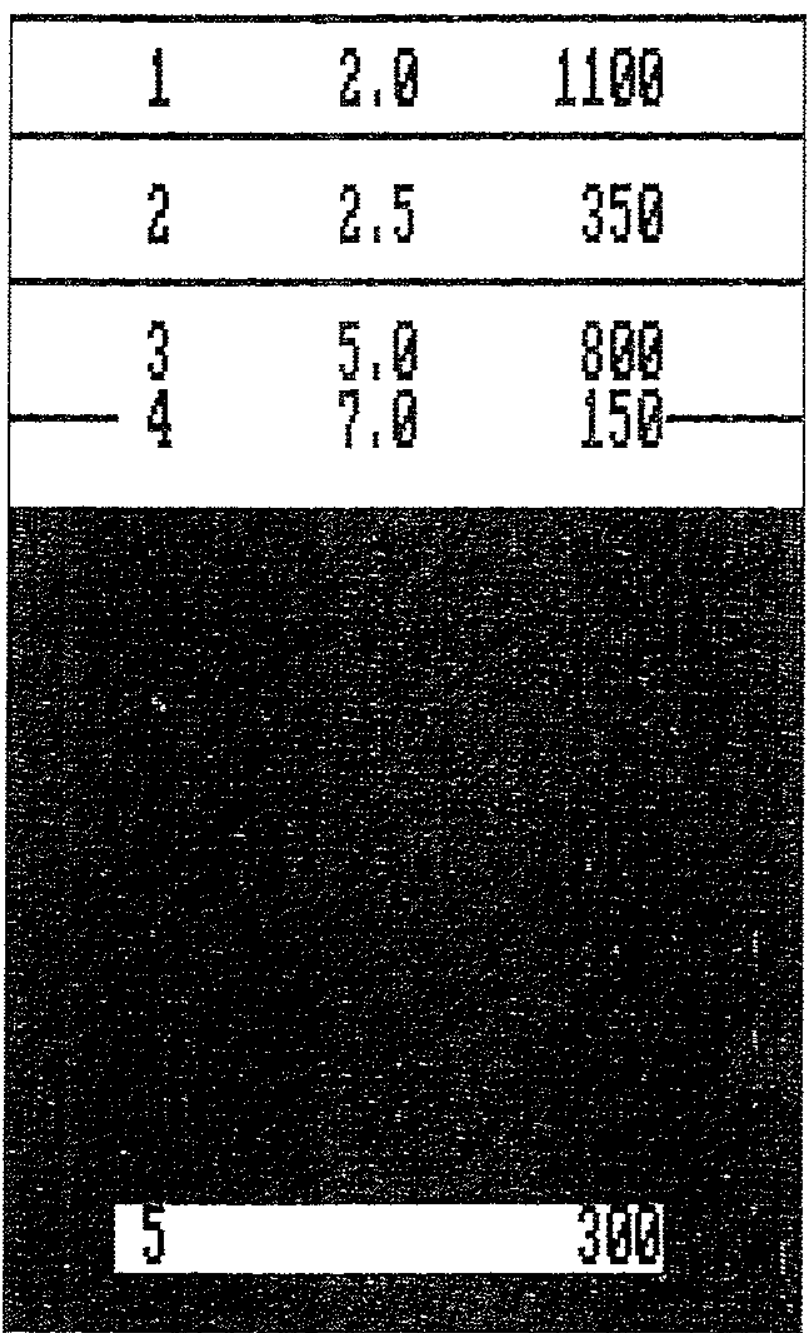




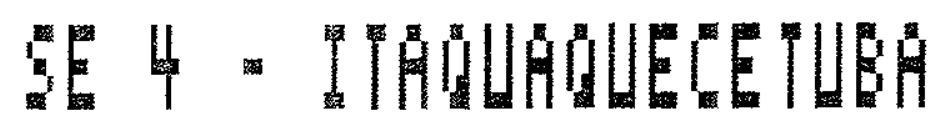

$-3000$

$16 \times-4$<smiles>[Te]=[Te]</smiles>

$7 x+y+y$

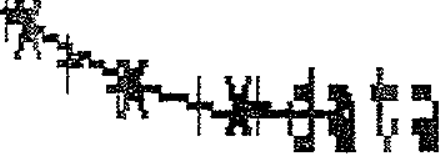




\section{SCHLLABERGER HODELO DE SONDAGEH SE 5 - ITAQUÁQLECETUBA}

ESPCCAHENTO MEISTIUIDADE DADO ERRO
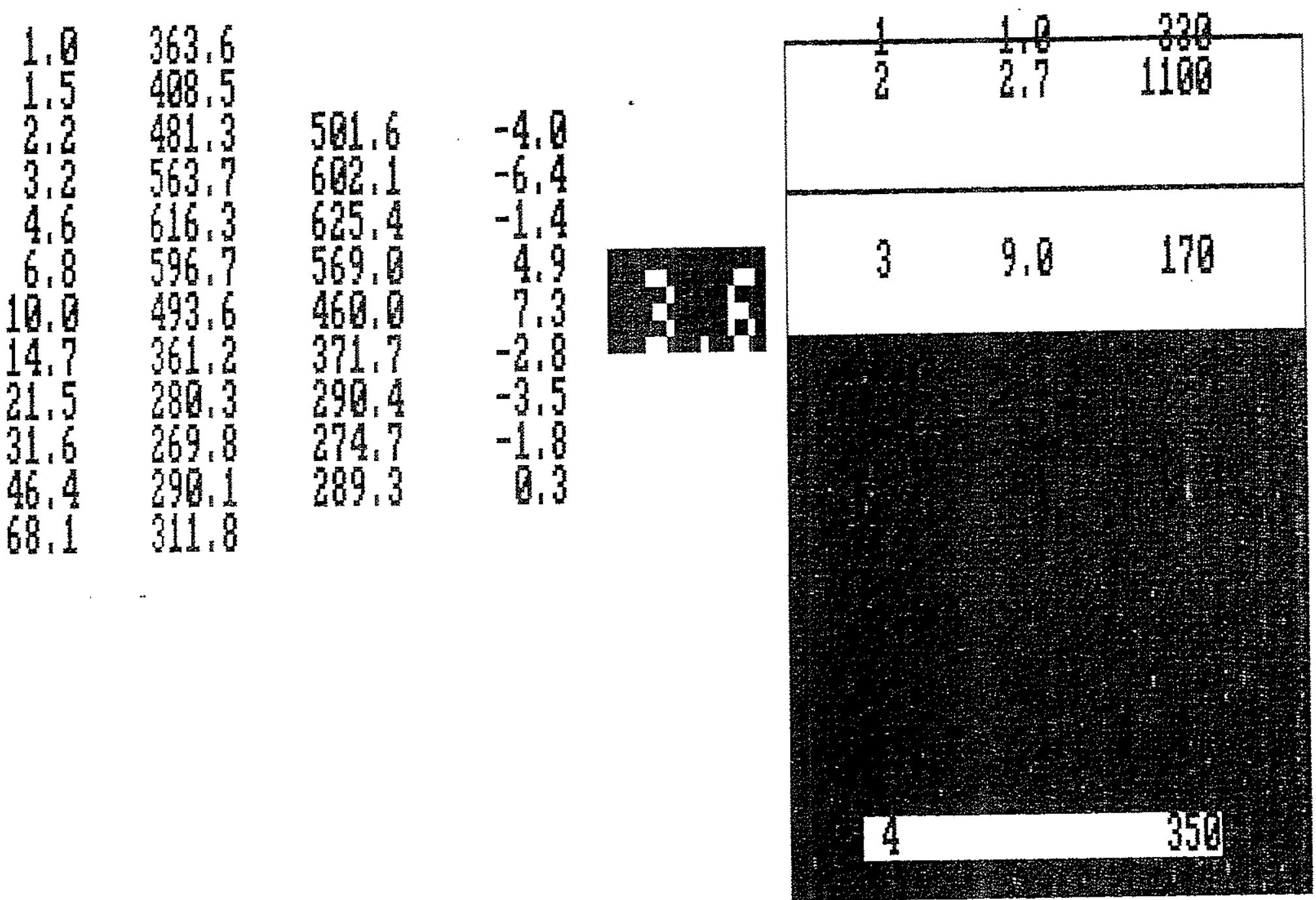


\section{SE - I}

$-10000$

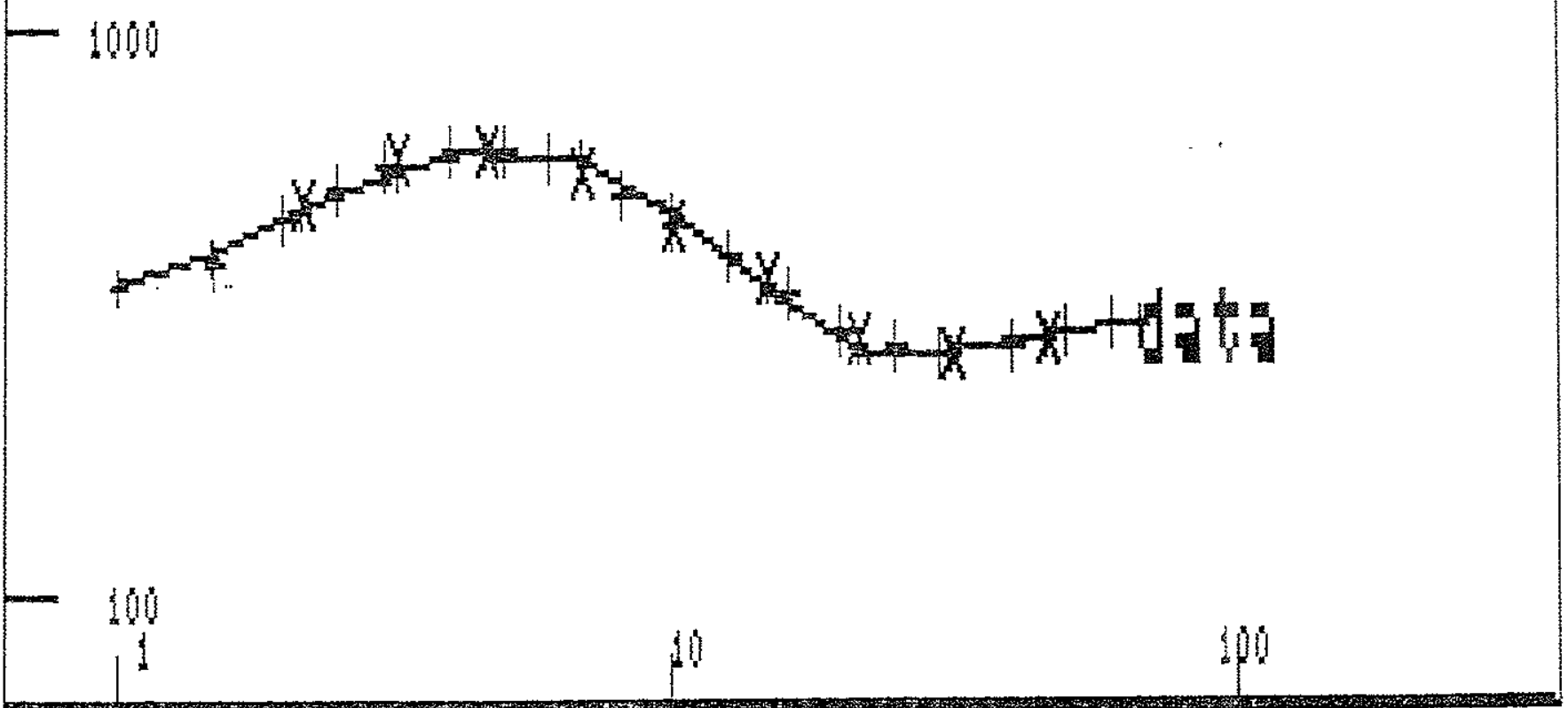




\section{SCHLLHBERGER HODELO DE SONDAGEM SE 6 - ITÁQLAQQUECETUBA}

ESPCAMEMTO REISTIUIDADE DADO ERRO

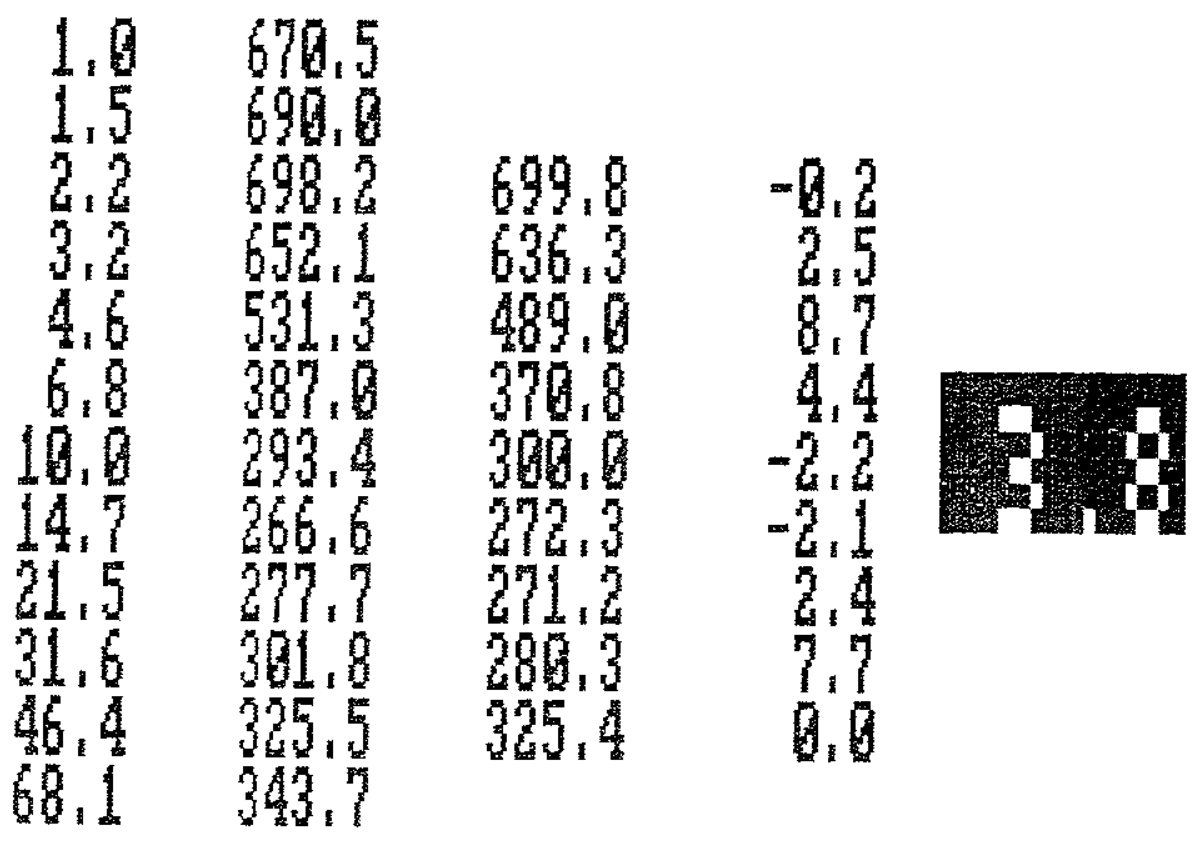

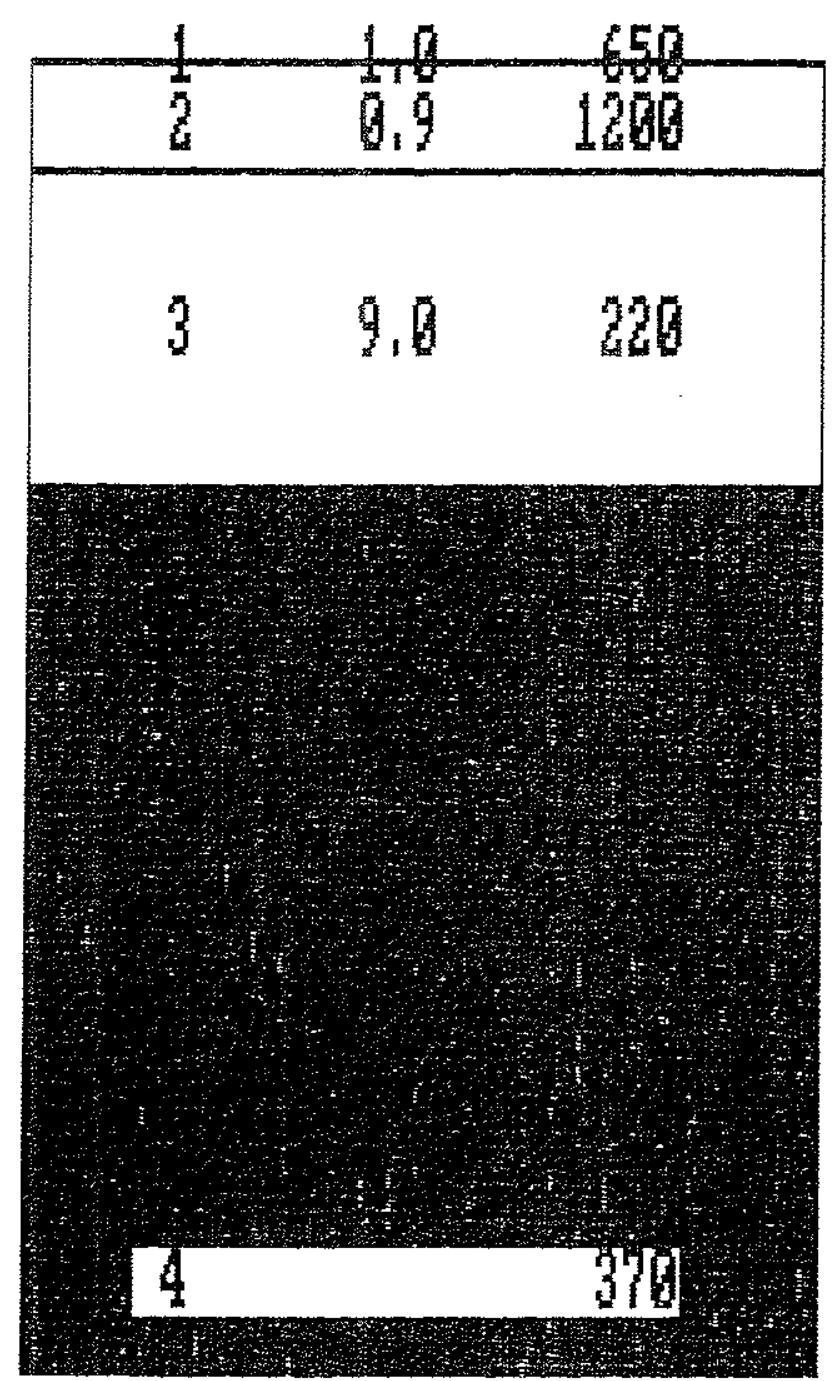




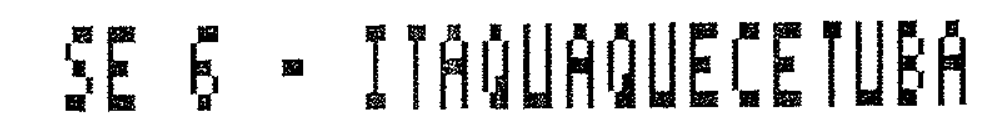

$-10000$

1000

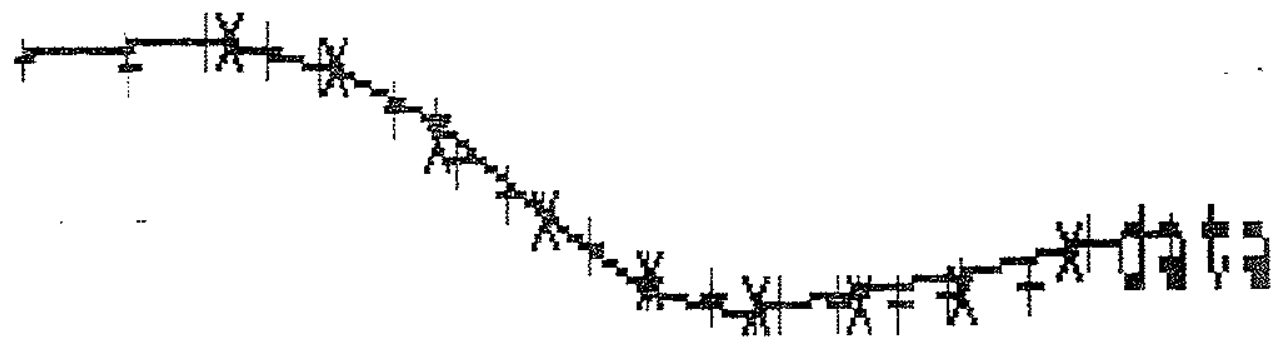

$-100$

11 
ANEXO B

\section{LAUDOS LABORATORIAIS DAS ANÁLISES}

MICROBIOLÓGICAS 
Universidade de São Paulo

Instituto de Ciências Biomédicas

Departamento de Microbiologia
Av. Prof. Lineu Prestes, 1374 $0508-900$ - São Pauto - SP

Brasil

Tel: (011) 818-7250

Fax: (011) 818-7354

São Paulo, 20 de agosto de 1997

\begin{tabular}{|c|c|c|c|}
\hline $\mathbf{n}^{\prime}$ do poço & $\begin{array}{c}\text { NMP' coliformes } \\
\text { totais/100mL }\end{array}$ & $\begin{array}{c}\text { NMP coliformes } \\
\text { fecais/100mL }\end{array}$ & Colifagos /100mL \\
\hline 19 & 50 & 2 & 0 \\
\hline 20 & 130 & $<2$ & 0 \\
\hline 21 & 23 & 23 & 0 \\
\hline 26 & 50 & $<2$ & 0 \\
\hline 29 & 2 & $<2$ & 0 \\
\hline 30 & 130 & $<2$ & 0 \\
\hline 4 & $<2$ & $<2$ & 0 \\
\hline 40 & 220 & 2 & 0 \\
\hline 42 & $<2$ & $<2$ & 0 \\
\hline 44 & $\geq 1600$ & 4 & 0 \\
\hline 45 & 300 & 240 & 0 \\
\hline 46 & 4 & $<2$ & 0 \\
\hline 49 & $<2$ & $<2$ & 0 \\
\hline 51 & 14 & $<2$ & $<2$ \\
\hline 41 & 17 & & 0 \\
\hline
\end{tabular}


Universidade de São Paulo Instituto de Ciências Biomédicas

Departamento de Microbiologia
Av. Prof. Lineu Prestes, 1374

O5508-900 - São Paulo - SP

Brasil

Tel: (011) 818-7250

Fax: (011) 818-7354

São Paulo, 16 de setembro de 1997

\begin{tabular}{|c|c|c|c|c|c|}
\hline $\begin{array}{l}n^{0} \text { do } \\
\text { poço }\end{array}$ & $\begin{array}{c}\text { NMP } \\
\text { coliformes } \\
\text { totais } / 100 \mathrm{~mL}\end{array}$ & $\begin{array}{c}\text { NMP } \\
\text { coliformes } \\
\text { fecais } / 100 \mathrm{~mL}\end{array}$ & Colifagos $/ 100 \mathrm{~mL}$ & $\begin{array}{l}\text { Salmonella sp } \\
\text { em 5L }\end{array}$ & $\begin{array}{c}\text { Oocistos de } \\
\text { Cryptosporidium sp } \\
\text { em } 10 \mathrm{~L}\end{array}$ \\
\hline 19 & 500 & 17 & 0 & ausência & presença \\
\hline 20 & 1600 & $<2$ & 0 & ausência & ausência \\
\hline 21 & 30 & $<2$ & 0 & ausência & ausência \\
\hline 26 & 7 & $<2$ & 0 & & \\
\hline 2) & 8 & 2 & 0 & & \\
\hline 30 & 170 & 22 & 620 & & \\
\hline 4 & $<2$ & $<2$ & 0 & & \\
\hline 40 & 34 & 2 & 25 & & \\
\hline 42 & 4 & $<2$ & 0 & & \\
\hline 44 & 500 & 13 & 0 & ausência & presença \\
\hline 45 & 1600 & 140 & 50 & ausência & ausência \\
\hline 46 & 27 & $<2$ & 0 & ausência & ausência \\
\hline 49 & 8 & $<2$ & 0 & & \\
\hline 51 & 7 & $<2$ & 0 & & \\
\hline 41 & 33 & $<2$ & 0 & & \\
\hline $\begin{array}{c}\text { Córrego } \\
C_{1}\end{array}$ & 50000 & 13000 & & & \\
\hline $\begin{array}{c}\text { Córrego } \\
\mathrm{C}_{1}\end{array}$ & 500000 & 50000 & & & \\
\hline
\end{tabular}




\begin{tabular}{|l|l|l|}
\hline$y$ & $\begin{array}{l}\text { Universidade de São Paulo } \\
\text { Instituto de Ciências Biomédicas } \\
\text { Departamento de Microbiologia }\end{array}$ & $\begin{array}{l}\text { Av. Prof. Lineu Prestes, 1374 } \\
\text { Osf508-900 - São Paulo - SP } \\
\text { Brasil } \\
\text { Tel: (011) 818-7259 } \\
\text { Fax: (011) 818-7354 }\end{array}$ \\
\hline
\end{tabular}

São Paulo, 27 de outubro de 1997

\begin{tabular}{|c|c|c|c|}
\hline $\mathrm{n}^{\prime}$ do poço & $\begin{array}{l}\text { NMP coliformes } \\
\text { totais } 100 \mathrm{~mL}\end{array}$ & $\begin{array}{l}\text { NMP coliformes } \\
\text { fecais } / 100 \mathrm{~mL}\end{array}$ & Colifagos $/ 100 \mathrm{~mL}$ \\
\hline 19 & 1600 & 30 & 0 \\
\hline 20 & 170 & $<2$ & 25 \\
\hline 21 & 30 & $<2$ & 130 \\
\hline 26 & 500 & $<2$ & 0 \\
\hline 29 & 240 & 13 & 0 \\
\hline 30 & 240 & 17 & 0 \\
\hline 4 & 4 & $<2$ & 0 \\
\hline 40 & 500 & 17 & 0 \\
\hline 42 & $<2$ & $<2$ & 0 \\
\hline 44 & 1600 & 220 & 0 \\
\hline 45 & 900 & 500 & 0 \\
\hline 46 & 4 & $<2$ & 0 \\
\hline 49 & 220 & $<2$ & 0 \\
\hline 51 & 170 & $<2$ & 0 \\
\hline 41 & 900 & 900 & 15 \\
\hline
\end{tabular}




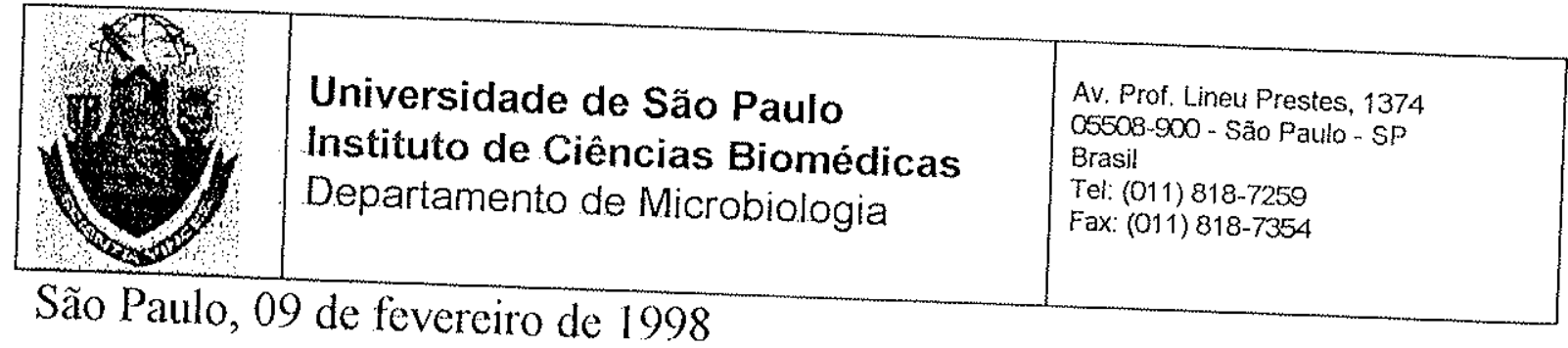

\begin{tabular}{|c|c|c|c|c|c|}
\hline $\begin{array}{l}\mathrm{n}^{\prime \prime} \mathrm{do} \\
\text { poço }\end{array}$ & \begin{tabular}{|c|} 
NMP \\
coliformes \\
totais $/ 100 \mathrm{~mL}$
\end{tabular} & $\begin{array}{c}\text { NMP } \\
\text { coliformes } \\
\text { fecais } / 100 \mathrm{~mL}\end{array}$ & Colifagos $/ 100 \mathrm{~mL}$ & $\begin{array}{c}\text { Salmonella } \\
\text { sp em 5L }\end{array}$ & $\begin{array}{c}\text { Oocistos de } \\
\text { Cryptosporidium } \\
\text { sp em 10L }\end{array}$ \\
\hline 19 & $\geq 1600$ & $\geq 1600$ & 1560 & ausência & presença \\
\hline 20 & $\geq 1600$ & $\geq 1600$ & 0 & ausência & ausência \\
\hline 21 & $\geq 1600$ & $\geq 1600$ & 85 & ausência & presença \\
\hline 26 & $\geq 1600$ & 13 & 0 & & \\
\hline 29 & $\therefore 16000$ & 130 & 5 & & \\
\hline 30 & $<2$ & $<2$ & 0 & & \\
\hline 4 & 4 & 50 & 0 & & \\
\hline 10 & $\because 1600$ & 17 & () & & \\
\hline 42 & 23 & 23 & 0 & & \\
\hline 44 & $\geq 1600$ & $\geq 1600$ & 0 & ausência & presença \\
\hline 45 & 900 & 500 & 0 & ausência & presença \\
\hline 46 & 17 & 4 & 0 & ausência & ausência \\
\hline 49 & 17 & 2 & 0 & & \\
\hline 51 & 23 & $<2$ & 0 & & \\
\hline 41 & $\geq 1600$ & 8 & 0 & & \\
\hline
\end{tabular}


Universidade de São Paulo Instituto de Ciências Biomédicas Departamento de Microbiologia
Av. Prof. Lineu Prestes, 1374

05508-900 - São Paulo - SP

Brasil

Tel: (011) 818-7259

Fax: (011) 818-7354

São Paulo, 02 de março de 1998

\begin{tabular}{|c|c|c|c|}
\hline $\mathbf{n}^{\mathbf{0}}$ do poço & $\begin{array}{c}\text { NMP coliformes } \\
\text { totais/100mL }\end{array}$ & $\begin{array}{c}\text { NMP coliformes } \\
\text { fecais/100mL }\end{array}$ & Colifagos /100mL \\
\hline 19 & $\geq 1600$ & 900 & 80 \\
\hline 20 & $\geq 1600$ & 4 & 0 \\
\hline 21 & $\geq 1600$ & 220 & 0 \\
\hline 26 & $\geq 1600$ & 2 & 0 \\
\hline 29 & $\geq 1600$ & 900 & 0 \\
\hline 30 & $\geq 1600$ & 280 & 0 \\
\hline 4 & 33 & 4 & 0 \\
\hline 40 & $\geq 1600$ & $<2$ & 0 \\
\hline 42 & 23 & $<2$ & 145 \\
\hline 44 & $\geq 1600$ & $\geq 1600$ & 0 \\
\hline 45 & 900 & 50 & 0 \\
\hline 46 & 4 & $<2$ & 0 \\
\hline 49 & 17 & $<2$ & 0 \\
\hline 51 & $\geq 1600$ & $<2$ & 0 \\
\hline 41 & & & \\
\hline
\end{tabular}




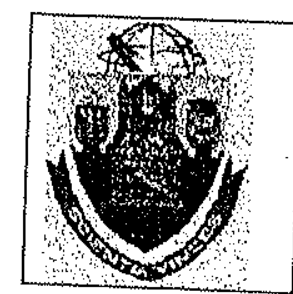

Universidade de São Paulo Instituto de Ciências Biomédicas

Departamento de Microbiologia

Tel: (011) 818-7250

Fax: (011) 818-7354

São Paulo, 23 de março de 1998

\begin{tabular}{|c|c|c|c|c|c|}
\hline$n^{0}$ do poço & $\begin{array}{c}\text { NMP } \\
\text { coliformes } \\
\text { totais } / 100 \mathrm{~mL}\end{array}$ & $\begin{array}{c}\text { NMP } \\
\text { coliformes } \\
\text { fecais/ } 100 \mathrm{~mL}\end{array}$ & Colifagos $/ 100 \mathrm{~mL}$ & $\begin{array}{c}\text { Salmonella } \\
\text { sp em 5L }\end{array}$ & $\begin{array}{c}\text { Oocistos de } \\
\text { Cryptosporidium } \\
\text { sp em 10L }\end{array}$ \\
\hline 19 & $\geq 1600$ & $\geq 1600$ & 125 & ausência & presença \\
\hline 20 & 1600 & $<2$ & 0 & ausência & ausência \\
\hline 21 & $\geq 1600$ & 300 & 0 & ausência & presença \\
\hline 26 & 1600 & $<2$ & 0 & & \\
\hline 29 & $\geq 1600$ & 1600 & 125 & & \\
\hline 30 & 21600 & $\because 1600$ & 0 & & \\
\hline 4 & 22 & 11 & 0 & & \\
\hline 40 & $\geq 1600$ & 30 & 0 & & \\
\hline 42 & 130 & 2 & () & & \\
\hline 44 & $\geq 1600$ & 1600 & 205 & ausênciá & presença \\
\hline 45 & $\geq 1600$ & 1600 & 0 & ausência & presença \\
\hline 46 & 900 & $<2$ & 0 & auscencia & presença \\
\hline 49 & 8 & 8 & 0 & & \\
\hline 51 & 27 & $<2$ & 0 & & \\
\hline 41 & $\geq 1600$ & 8 & 0 & & \\
\hline
\end{tabular}




\begin{tabular}{|c|c|c|}
\hline 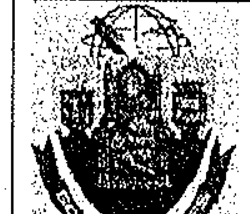 & $\begin{array}{l}\text { Universidade de São Paulo } \\
\text { Instituto de Ciências Biomédicas } \\
\text { Departamento de Microbiologia }\end{array}$ & $\begin{array}{l}\text { Av. Prof. Lineu Prestes, } 1374 \\
\text { O5508-900 - Säo Paulo - SP } \\
\text { Brasil } \\
\text { Tel: (011) 818-7259 } \\
\text { Fax: (011) 818-7354 }\end{array}$ \\
\hline
\end{tabular}

São Paulo, 16 de abril de 1998

\begin{tabular}{|c|c|c|c|}
\hline n" do poço & $\begin{array}{l}\text { NMP coliformes } \\
\text { totais } / 100 \mathrm{~mL}\end{array}$ & $\begin{array}{l}\text { NMP coliformes } \\
\text { feca is/100mL }\end{array}$ & Colifagos $/ 100 \mathrm{~mL}$ \\
\hline 19 & 1600 & 900 & 0 \\
\hline 20 & 500 & $<2$ & 0 \\
\hline 21 & 300 & 7 & 0 \\
\hline 26 & 130 & $<2$ & 0 \\
\hline 29 & $\geq 1600$ & $\geq 1600$ & 75 \\
\hline 30 & $\geq 1600$ & 1600 & 0 \\
\hline 4 & 50 & 8 & 0 \\
\hline 40 & $\geq 1600$ & 2 & 0 \\
\hline 42 & $\geq 1600$ & $<2$ & 0 \\
\hline 44 & 1600 & 300 & 15 \\
\hline 45 & 900 & 4 & 0 \\
\hline 46 & 1600 & $<2$ & 0 \\
\hline 49 & $<2$ & $<2$ & 0 \\
\hline 51 & $\geq 1600$ & $<2$ & 0 \\
\hline 41 & 50 & $<2$ & 0 \\
\hline
\end{tabular}

\begin{tabular}{|l|c|c|}
\hline Fossa 1 & ausência de Salmonella sp em $\mathrm{L}$ & $\begin{array}{c}\text { presença de oocistos de } \\
\text { ('yptosporidium sp en } \mathrm{IL}\end{array}$ \\
\hline
\end{tabular}




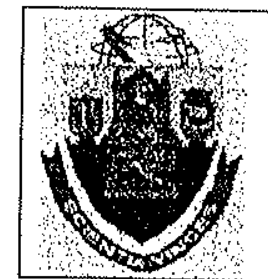

Universidade de São Paulo Instituto de Ciências Biomédicas Departamento de Microbiologia

São Paulo, 08 de maio de 1998

\begin{tabular}{|c|c|c|c|c|c|}
\hline $\begin{array}{l}\mathrm{n}^{0} \mathrm{do} \\
\text { poço }\end{array}$ & $\begin{array}{c}\text { NMP } \\
\text { coliformes } \\
\text { totais } / 100 \mathrm{~mL}\end{array}$ & $\begin{array}{c}\text { NMP } \\
\text { coliformes } \\
\text { fecais } / 100 \mathrm{~mL}\end{array}$ & Colifagos $/ 100 \mathrm{~mL}$ & $\begin{array}{c}\text { Salmonella sp } \\
\text { em 5L }\end{array}$ & $\begin{array}{c}\text { Oocistos de } \\
\text { Cryptosporidium } \\
s p \text { em } 10 \mathrm{~L}\end{array}$ \\
\hline 19 & $\geq 1600$ & 170 & 670 & ausência & presença \\
\hline 20 & 1600 & 4 & 0 & ausência & ausência \\
\hline 21 & 300 & $<2$ & 0 & ausência & presença \\
\hline 26 & $\geq 1600$ & 9 & 0 & & \\
\hline 29 & 140 & 22 & 25 & & \\
\hline 30 & 300 & 7 & 0 & & \\
\hline 4 & 50 & 50 & 5 & & \\
\hline 10) & 16000 & $: 8$ & () & & \\
\hline 42 & 900 & 2 & 0 & & \\
\hline 44 & $\geq 1600$ & 130 & 0 & ausência & presença \\
\hline 45 & 900 & 80 & 15 & ausĉncia & presença \\
\hline 46 & 300 & $<2$ & 10 & ausência & presença \\
\hline 49 & 50 & $<2$ & 20 & & \\
\hline 51 & $\geq 1600$ & $<2$ & 0 & & \\
\hline 41 & 50 & $<2$ & 0 & & \\
\hline córrego 1 & $\geq 1600$ & $\geq 1600$ & & & \\
\hline córrego 2 & $\geq 1600$ & $\geq 1600$ & & & \\
\hline
\end{tabular}




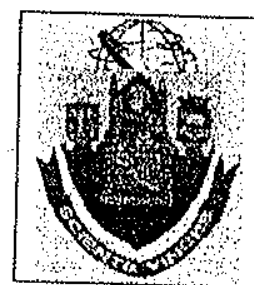

Universidade de São Paulo Instituto de Ciências Biomédicas

Departamento de Microbiologia

São Paulo, 17 de junho de 1998

\begin{tabular}{|c|c|c|c|}
\hline$n^{\prime \prime}$ do poco & $\begin{array}{l}\text { NMP coliformes } \\
\text { tolais } / 100 \mathrm{ml}\end{array}$ & $\begin{array}{l}\text { NMP coliformes } \\
\text { fecais/ } 100 \mathrm{~mL}\end{array}$ & Colifagos $/ 100 \mathrm{~mL}$ \\
\hline 19 & 110 & $<2$ & 0 \\
\hline 20 & 900 & $<2$ & 0 \\
\hline 21 & 70 & 2 & 0 \\
\hline 26 & 80 & $<2$ & 0 \\
\hline 29 & $\geq 1600$ & 130 & 285 \\
\hline 30 & 1600 & 130 & 0 \\
\hline 4 & 2 & $<2$ & 0 \\
\hline 40 & 220 & $<2$ & 330 \\
\hline 42 & 2 & $<2$ & 0 \\
\hline 44 & $\geq 1600$ & 110 & 5 \\
\hline 45 & 500 & 2 & 60 \\
\hline 46 & 14 & $<2$ & 0 \\
\hline 49 & 17 & $<2$ & 85 \\
\hline 51 & 70 & $<2$ & 0 \\
\hline 41 & 130 & 2 & 0 \\
\hline
\end{tabular}

Fossa 2 ausência de Salmonella sp em IL presença de oocistos de (ryplosporidium sp em $\mathrm{L}$ 


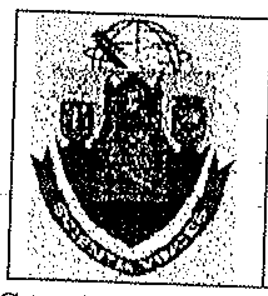

Universidade de São Paulo Instituto de Ciências Biomédicas Departamento de Microbiologia

São Paulo, 21 de julho de 1998

\begin{tabular}{|c|c|c|c|}
\hline $\mathbf{n}^{\mathbf{0}}$ do poço & $\begin{array}{c}\text { NMP coliformes } \\
\text { totais/100mL }\end{array}$ & $\begin{array}{c}\text { NMP coliformes } \\
\text { fecais/100mL }\end{array}$ & Colifagos /100 mL \\
\hline 19 & 80 & 2 & 0 \\
\hline 20 & 1600 & $<2$ & 0 \\
\hline 21 & $<2$ & $<2$ & 0 \\
\hline 26 & 500 & $<2$ & 0 \\
\hline 29 & $\geq 1600$ & 17 & 0 \\
\hline 30 & 11 & $<2$ & 0 \\
\hline 4 & 21600 & $<2$ & 0 \\
\hline 40 & 21600 & $\geq 1600$ & 0 \\
\hline 12 & 500 & 13 & 5 \\
\hline 44 & 900 & 2 & 0 \\
\hline 45 & $<2$ & $<2$ & 0 \\
\hline 46 & $<2$ & $<2$ & 145 \\
\hline 49 & 4 & 2 & 0 \\
\hline 51 & & & 0 \\
\hline 41 & & 2 & 0 \\
\hline
\end{tabular}

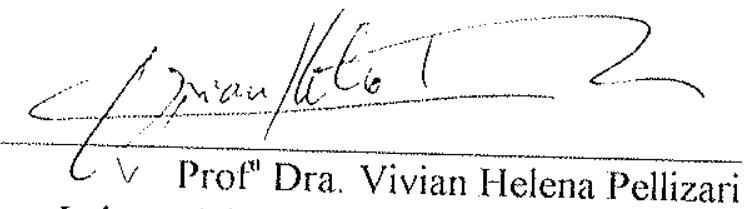

Laboratório de Microbiologia Ambiental 


\section{ANEXO C}

\section{LAUDOS LABORATORIAIS DAS ANÁLISES}

QUÍMICAS 


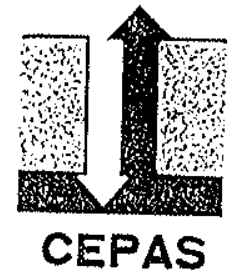

CEPAS

\section{UNIVERSIDADE DE SÃO PAULO \\ INSTITUTO DE GEOCIENCIAS \\ CENTRO DE PESQUISAS DE ÁGUAS SUBTERRÂNEAS}

LABORATÓRIO DE HIDROGEOQUÍMICA II

Emissão: 21/08/97

\section{BOLETIM DE ANÁLISE}

Resultado das análises dos ânions $\mathrm{F}^{-}, \mathrm{Cl}^{-}, \mathrm{NO}_{2}{ }^{-}, \mathrm{Br}^{-}, \mathrm{NO}_{3}{ }^{-}, \mathrm{PO}_{4}{ }^{3-}$ e $\mathrm{SO}_{4}{ }^{2-}$ realizadas pelo processo de cromatografia líquida no aparelho DIONEX $2010 \mathrm{i}$, dos cátions $\mathrm{Na}^{+} \mathrm{e} \mathrm{K}^{+}$realizadas pelo processo de fotometria de chama desenvolvido no fotômetro $\mathrm{B} 262$ da Micronal e dos cátions $\mathrm{Cu}^{2+}, \mathrm{Pb}^{2+}, \mathrm{Zn}^{2+}$, $\mathrm{Fe}^{\text {tolal }}, \mathrm{Cr}^{\text {lotal }}, \mathrm{Mn}^{2+}, \mathrm{Ni}^{2+}, \mathrm{Ba}^{2+}, \mathrm{Al}^{3+1}, \mathrm{Sr}^{2+-}, \mathrm{Ca}^{2+}$ e $\mathrm{Mg}^{2++}$ realizadas pelo processo de espectrofotometria desenvolvido no Aparelho de Absorção Atômica CG AA7000 BCe referente às amostras de água P.4; P.19; P.20; P.21; P.26; P.29; P.30; P.40; P.41; P.42; P.44; P.45; P.46; P.49 e P.51, coletadas em 26/09/97 nas unidades de monitoramento instaladas no Município de Itaquaquecetuba (RMSP)-SP., área onde se desenvolve o Projeto de Pesquisa "Impacto das Fossas no Aquífero Freático" e encaminhadas a este Laboratório pelo pósgraduando Rodrigo dos Santos Espínola sob orientação do Prof. Dr. Alberto Pacheco, financiado pela FAPESP.

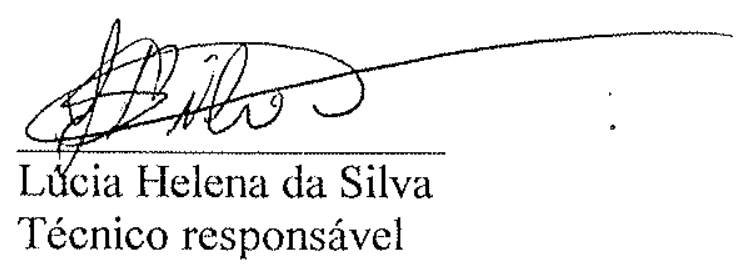

Técnico responsável

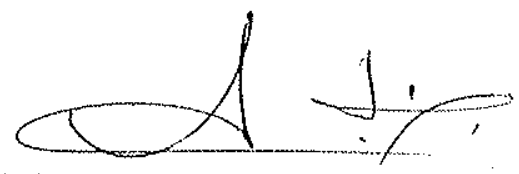

Profa. Dra. Annkarin A.K. e Silva e/ou Prof. Dr. Uriel Duarte Coordenador dos Laboratórios/CEPAS 


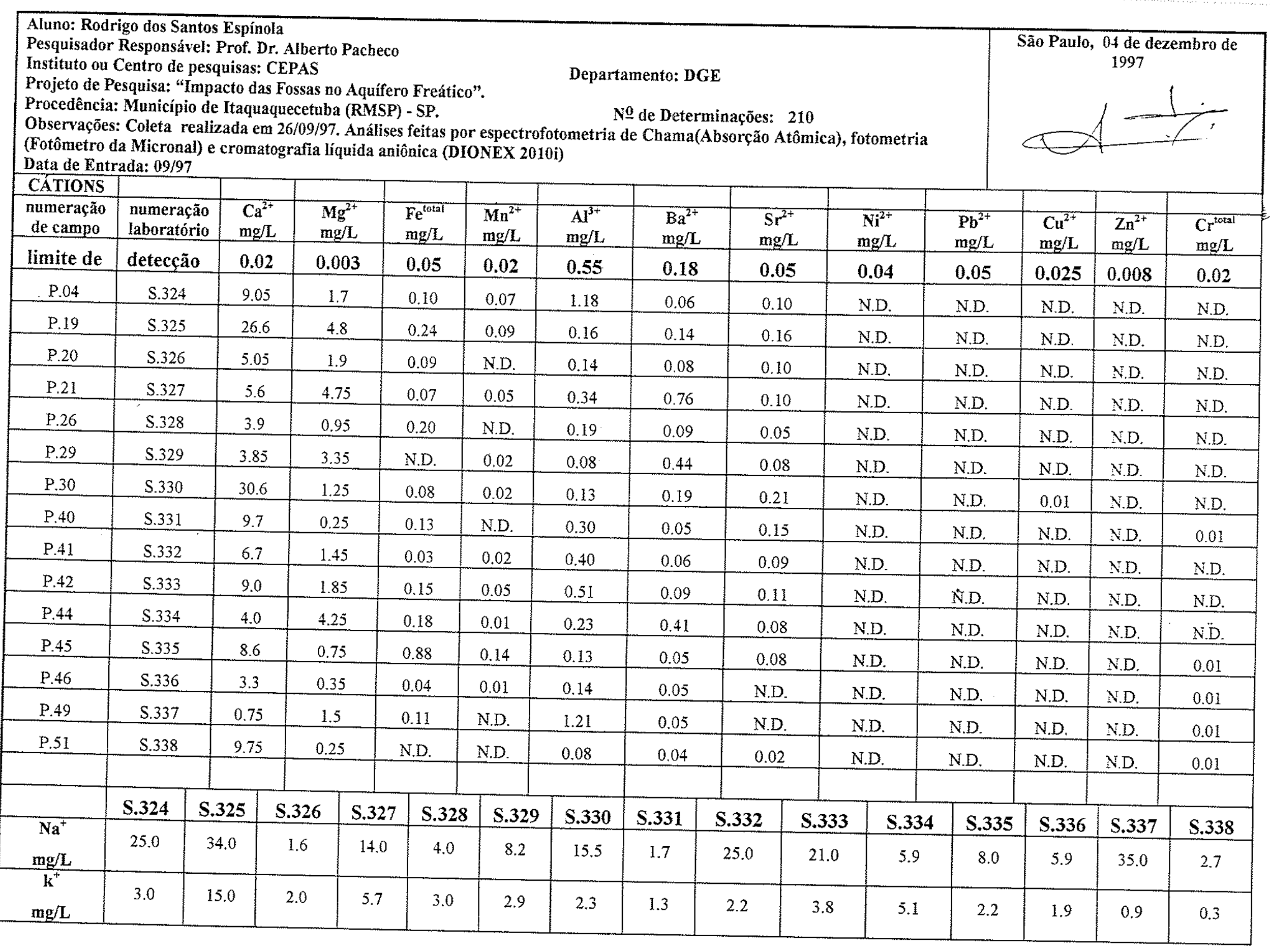




\begin{tabular}{|c|c|c|c|c|c|c|c|c|c|}
\hline \multicolumn{9}{|c|}{$\begin{array}{l}\text { Aluno: Rodrigo dos Santos Espínola } \\
\text { Pesquisador Responsável: Prof. Dr. Alberto Pacheco } \\
\text { Instituto ou Centro de pesquisas: CEPAS }\end{array}$} & $\begin{array}{l}\text { São Paulo, 04 de dezembro de } \\
1997\end{array}$ \\
\hline ÂNIONS & & $\begin{array}{c}\mathrm{F} \\
\mathrm{mg} / \mathrm{L}\end{array}$ & $\begin{array}{c}\mathrm{Cl} \\
\mathrm{mg} / \mathrm{L}\end{array}$ & $\begin{array}{l}\mathrm{NO}_{2}^{-} \\
\mathrm{mg} / \mathrm{h}\end{array}$ & $\begin{array}{c}\mathrm{Br} \\
\mathrm{mg} / \mathrm{L}\end{array}$ & $\begin{array}{l}\mathrm{NO}_{3}{ }^{\circ} \\
\mathrm{mg} / \mathrm{L}\end{array}$ & $\begin{array}{l}\mathrm{PO}_{4}^{3-} \\
\mathrm{mg} / \mathrm{L}\end{array}$ & $\begin{array}{l}\mathrm{SO}_{4}{ }^{2-} \\
\mathrm{mg} / \mathrm{L}\end{array}$ & \\
\hline P.04 & S.324 & 0.06 & 23.66 & N.D. & 0.09 & 66.31 & 0.19 & 2.02 & \\
\hline P.19 & S. 325 & 0.11 & 38.28 & N.D. & 0.16 & 56.34 & 0.04 & 16.63 & \\
\hline P.20 & S.326 & 0.04 & 1.13 & N.D. & N.D. & 9.78 & 0.55 & 0.61 & \\
\hline P.21 & S.327 & 0.23 & 11.4 & N.D. & 0.03 & 54.8 & 0.31 & 1.12 & \\
\hline P.26 & S. 328 & 0.03 & 1.41 & N.D. & N.D. & 0.98 & 0.78 & 0.61 & \\
\hline P.29 & S.329 & 0.04 & 3.53 & N.D. & 0.015 & 36.23 & 0.009 & 0.23 & \\
\hline P.30 & S. 330 & 0.24 & 14.55 & N.D. & 0.03 & 11.56 & 0.04 & 5.99 & \\
\hline P. 40 & S.331 & 0.04 & 2.98 & N.D. & 0.014 & 1.81 & 0.04 & 0.96 & \\
\hline P. 41 & S. 332 & 0.03 & 10.99 & N.D. & 0.04 & 71.59 & 0.29 & 0.45 & \\
\hline P. +2 & S.333 & 0.07 & 31.48 & N.D. & 0.47 & 25.11 . & 0.007 & 4.52 & \\
\hline P. 4 & S.334 & 0.06 & 3.79 & N.D. & 0.04 & 45.61 & 0.02 & 0.66 & \\
\hline$P .45$ & S.335 & 0.06 & 8.58 & N.D. & 0.19 & 5.61 & 0.02 & 1.48 & \\
\hline P. 46 & S. 336 & 0.015 & 6.06 & N.D. & 0.02 & 10.29 & 0.02 & 0.86 & \\
\hline P. 49 & S.337 & 0.02 & 16.21 & N.D. & 0.04 & 87.26 & 0.04 & 0.59 & \\
\hline P.51 & S.338 & N.D. & 3.05 & N.D. & 0.013 & 3.09 & 0.014 & 0.65 & \\
\hline & & & & & & & & & \\
\hline
\end{tabular}


LABORATÓRIO DE HIDROGEOQUÍMICA II

Emissão: 20/07/98

\title{
BOLETIM DE ANÁLISE
}

\begin{abstract}
Resultado das análises dos ânions $\mathrm{F}^{-}, \mathrm{Cl}^{-}, \mathrm{NO}_{2}{ }^{-}, \mathrm{Br}^{-}, \mathrm{NO}_{3}^{-}, \mathrm{PO}_{4}{ }^{3 *}$ e $\mathrm{SO}_{4}{ }^{2-}$ realizadas pelo processo de cromatografia líquida no aparelho DIONEX $2010 \mathrm{i}$, dos cátions $\mathrm{Na}^{-1} \mathrm{e} \mathrm{K}^{+}$realizadas pelo processo de fotometria de chama desenvolvido no fotômetro $\mathrm{B} 262$ da Micronal e dos cátions $\mathrm{Cu}^{2+}, \mathrm{Pb}^{2+}, \mathrm{Zn}^{2+}$, $\mathrm{Fe}^{\text {total }}, \mathrm{Cr}^{\text {total }}, \mathrm{Mn}^{2+}, \mathrm{Ni}^{2+}, \mathrm{Ba}^{2+}, \mathrm{Al}^{3+-}, \mathrm{Sr}^{2+}, \mathrm{Ca}^{2+} \mathrm{e} \mathrm{Mg}^{2+}$ realizadas pelo processo de espectrofotometria desenvolvido no Aparelho de Absorção Atômica CG AA7000 BCe referente às amostras de água dos poços P.4; P.19; P.20; P.21; P.26; P.29; P.30; P.40; P.41; P.42; P.44; P.45; P.46; P.49 c P.51 e kigua dos córregos 1 e 2, coletádas em 02/03/98 nas unidades de monitoramento instaladas no Município de Itaquaquecetuba (RMSP)-SP., área onde se desenvolve o Projeto de Pesquisa "Impacto das Fossas no Aquífero Freático" e encaminhadas a este Laboratório pelo pós-graduando Rodrigo dos Santos Espínola em 08/05/98 sob orientação do Prof. Dr. Alberto Pacheco, financiado pela FAPESP.
\end{abstract}

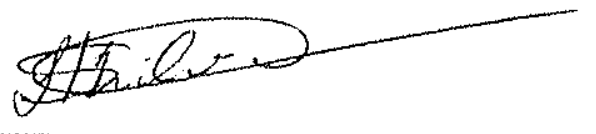

Lúcia Helena da Silva

Técnico responsável

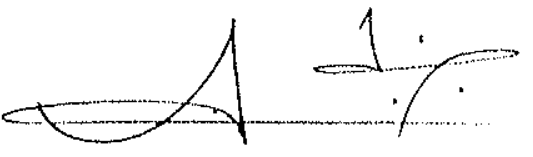

Prof. Dr. Uriel Duarte e/ou

Profa. Dra.Annkarin A.K. e Silva

Coordenador dos Laboratórios/CEPAS

Rua do Lago, 562 (Cidade Universitária) CEP 05508-900 São Paulo, SP-Brasil FAX: (011) 818 - 4207 -E-mail: cepas@edu.usp.br 


\begin{tabular}{|c|c|c|c|c|c|c|c|c|c|c|c|c|}
\hline \multicolumn{13}{|c|}{$\begin{array}{l}\text { Aluno: Rodrigo dos Santos Espínola } \\
\text { Pesquisador Responsável: Prof. Dr. Alberto Pacheco } \\
\text { Instituto ou Centro de pesquisas: CEPAS } \\
\text { Projeto de Pesquisa: "Impacto das Fossas no Aquífero Freático". } \\
\text { Procedência: Município de Itaquaquecetuba (RMSP) - SP. } \\
\text { Observaçōes: Coleta realizada em 02/03/98. Análises feitas por espectrofotometria de Chama(Absorção Atômica), fotometria } \\
\text { (Fotômetro da Micronal) e cromatografia líquida aniônica (DIONEX 2010i) } \\
\text { Data de Entrada: } 08 / 05 / 98\end{array}$} \\
\hline ÂNIONS & & $\begin{array}{c}F \\
\mathrm{mg} / \mathrm{L}\end{array}$ & $\begin{array}{c}\mathrm{Cl}^{-} \\
\mathrm{mg} / \mathrm{L}\end{array}$ & $\begin{array}{l}\mathrm{NO}_{2}{ }^{-} \\
\mathrm{m} \mathrm{g} / \mathrm{L}\end{array}$ & $\begin{array}{c}\mathrm{Br}^{-} \\
\mathrm{mg} / \mathrm{L}\end{array}$ & $\begin{array}{l}\mathrm{NO}_{3}^{-} \\
\mathrm{mg} / \mathrm{L}\end{array}$ & $\begin{array}{l}\mathrm{PO}_{4}^{3-} \\
\mathrm{mg} / \mathrm{L}\end{array}$ & $\begin{array}{l}\mathrm{SO}_{4}^{2+} \\
\mathrm{mg} / \mathrm{L}\end{array}$ & CÁTIONS & & $\begin{array}{c}\mathrm{Na}^{+} \\
\mathrm{mg} / \mathrm{L}\end{array}$ & $\begin{array}{c}\mathrm{K}^{\dagger} \\
\mathrm{mg} / \mathrm{L}\end{array}$ \\
\hline Córrego 1 & LH.16 & 0.06 & 8.40 & 2.60 & 0.07 & 3.40 & 0.12 & 2.25 & Córrego 1 & LH.16 & 10.2 & 4.1 \\
\hline Córrego 2 & LH.17 & 0.03 & 5.81 & 3.02 & 0.07 & 5.09 & 0.07 & 1.93 & Córrego 2 & LH.17 & 6.8 & 3.4 \\
\hline P.04 & LH.18 & 0.015 & 26.73 & N.D. & 0.05 & 90.08 & 0.31 & 5.35 & P.04 & LH. 18 & 38.0 & 5.0 \\
\hline P.19 & LH.19. & 0.05 & 34.59 & N.D. & 0.14 & 39.80 & 0.05 & 19.87 & P.19 & LH.19 & 35.0 & 20.0 \\
\hline P.20 & LH. 20 & 0.03 & 0.81 & N.D. & 0.02 & 11.90 & 0.25 & 0.44 & P.20 & LH.20 & 1.8 & 2.2 \\
\hline P.21 & LH.21 & 0.33 & 15.84 & N.D. & 0.03 & 71.98 & 0.10 & 1.60 & P.21 & LH.21 & 24.5 & 6.1 \\
\hline P.26 & LH.22 & 0.018 & 1.09 & N.D. & 0.007 & 0.94 & 0.08 & 0.38 & P. 26 & LH. 22 & 4.1 & 3.2 \\
\hline P. 29 & LH.23 & 0.27 & 5.22 & N.D. & N.D. & 604.94 & 0.09 & 0.51 & P.29 & LH. 23 & 8.8 & 3.5 \\
\hline P.30 & LH. 24 & 0.15 & 19.43 & N.D. & 0.05 & 13.86 & 0.03 & 8.73 & P. 30 & $\mathrm{LH} .24$ & 20.0 & 2.2 \\
\hline P. 40 & LH. 25 & 0.012 & 2.12 & N.D. & 0.012 & 1.24 & 0.02 & 0.46 & P. 40 & LH. 25 & 2.1 & 0.6 \\
\hline P. 41 & LH.26 & 0.23 & 23.81 & N.D. & 0.02 & 116.02 & 0.02 & 1.97 & P.41 & LH. 26 & 28.0 & 9.8 \\
\hline P.42 & LH. 27 & 0.21 & 45.84 & N.D. & 0.09 & 112.71 & 0.04 & 17.85 & P.42 & LH. 27 & 51.0 & 9.6 \\
\hline P.44 & LH.28 & 0.07 & 3.72 & N.D. & 0.19 & 37.62 & 0.02 & 0.95 & P.44 & LH. 28 & 5.4 & 5.5 \\
\hline P.45 & LH.29 & 0.03 & 8.01 & N.D. & 0.05 & 3.68 & 0.03 & 1.07 & P.45 & LH. 29 & 7.8 & 2.5 \\
\hline P.46 & LH. 30 & 0.02 & 9.56 & N.D. & 0.03 & 15.92 & 0.02 & 0.27 & P.46 & LH.30 & 10.4 & 2.7 \\
\hline P.49 & LH.31 & 0.05 & 14.30 & N.D. & 0.02 & 90.45 & 0.18 & $0 .+5$ & P.49 & LH.3I & 30.0 & 1.9 \\
\hline P.51 & LH. 32 & 0.012 & 2.91 & N.D. & 0.017 & 3.37 & 0.02 & 1.06 & P.51 & LH. 32 & 3.3 & 0.6 \\
\hline
\end{tabular}




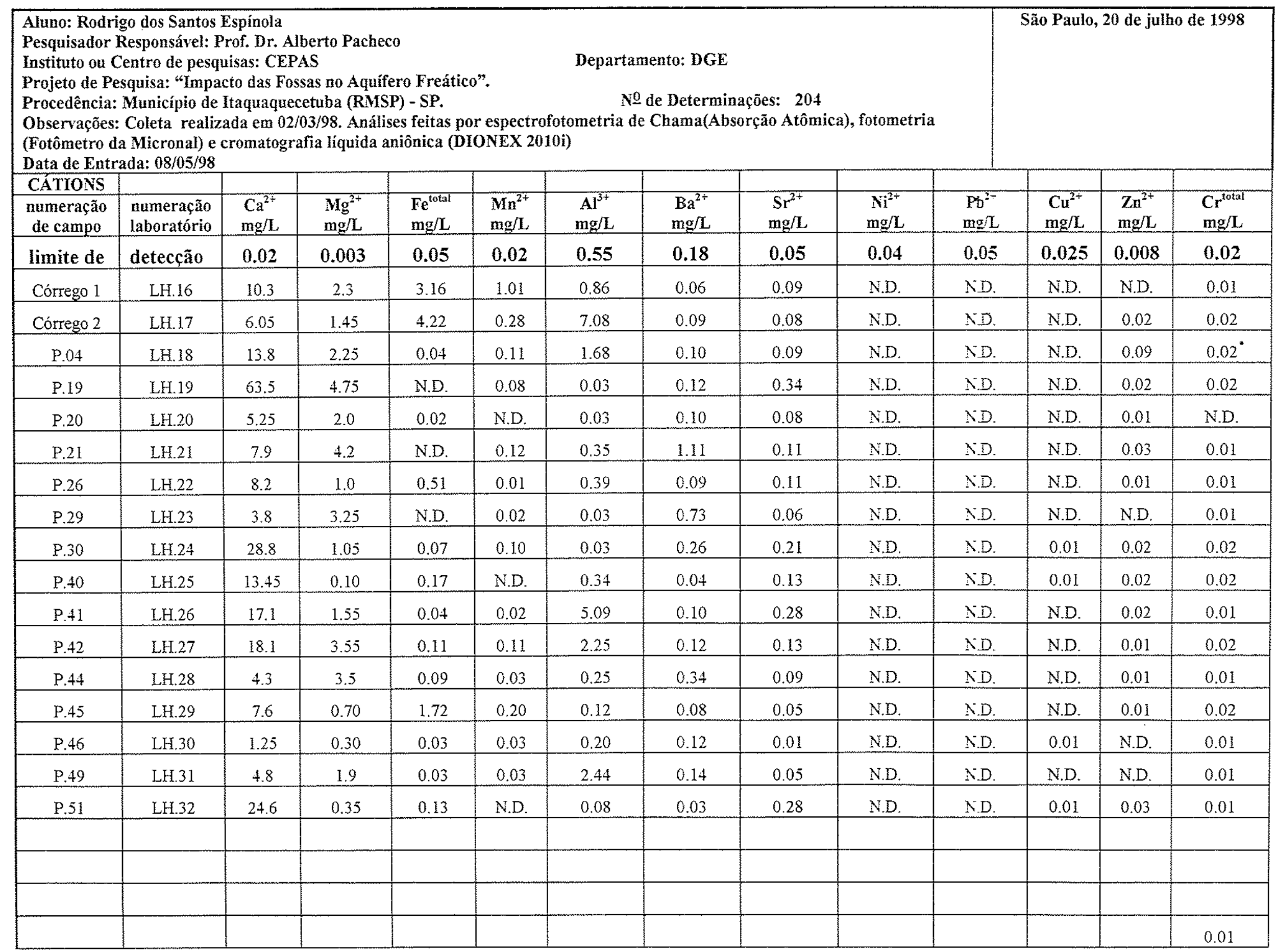


Sample Cross Reference

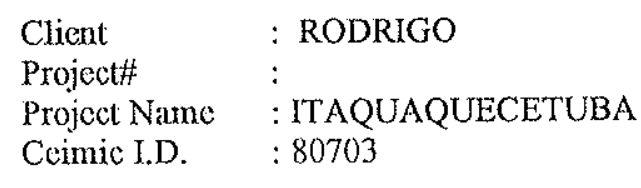

\begin{tabular}{|c|c|c|c|}
\hline SmpH & Sample ID & Matrix & Date Sampled \\
\hline 01 & $\mathrm{P} 04$ & Water & $06 / 17 / 98$ \\
\hline 02 & $P 19$ & Walcr & $06 / 17 / 98$ \\
\hline 03 & $P 20$ & Walcr & $06 / 17 / 98$ \\
\hline 04 & P 21 & Water & $06 / 17 / 98$ \\
\hline 05 & P 26 & Water & $06 / 17 / 98$ \\
\hline 06 & P 29 & Water & $06 / 17 / 98$ \\
\hline 07 & P 30 & Water & $06 / 17 / 98$ \\
\hline 08 & P 40 & Water & $06 / 17 / 98$ \\
\hline 09 & $P 41$ & Watcr & $06 / 17 / 98$ \\
\hline 10 & $\mathrm{P} 42$ & Water & $06 / 17 / 98$ \\
\hline 11 & P 44 & Water & $06 / 17 / 98$ \\
\hline 12 & P 45 & Water & $06 / 17 / 98$ \\
\hline 13 & P 46 & Water & $06 / 17 / 98$ \\
\hline 14 & $P 49$ & Water & $06 / 17 / 98$ \\
\hline 15 & P 51 & Water & $06 / 17 / 98$ \\
\hline 16 & CORREGO 1 & Water & $06 / 17 / 98$ \\
\hline 17 & CÓRREGO 2 & Water & $06 / 17 / 98$ \\
\hline 18 & FOSSA & Water & $06 / 17 / 98$ \\
\hline \multicolumn{4}{|c|}{ Analytical Schedule } \\
\hline \multirow{4}{*}{\multicolumn{2}{|c|}{$\begin{array}{l}\text { Analysis/Method } \\
\text { EPA } 350.2 \text { AMMONIA, AS N } \\
\text { SM 4500 B CHLORIDE } \\
\text { EPA 353.3 NITRATE }\end{array}$}} & \multicolumn{2}{|c|}{ Technique/Description } \\
\hline & & \multicolumn{2}{|c|}{ TITRIMETRIC METHOD } \\
\hline & & \multicolumn{2}{|c|}{ TITRIMETRIC METHOD } \\
\hline & & \multicolumn{2}{|c|}{ COLORIMETRIC METHOD } \\
\hline
\end{tabular}

CEIMIC STANDARD DISPOSAL PRACTICE

The sample (s) from this project will be disposed of thirly (30) days from the date of this report. If an extended storage period is required, please contact our laboratory prior to scheduled disposal date. In addition, if the sample(s) need to be returned to the client please notify the laboratory prior to disposal date.

Rua Brigadeiro Galvão, 535-A Cep: 01151-000 - São Paulo - SP - Brasil Tel:. (011) 3667-0126 Fax: (011) 826-1429 - c-mail: ceimic@8415.com.br 
General Chemistry Results

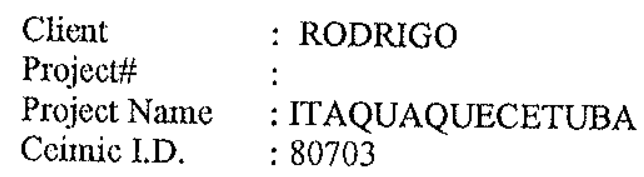

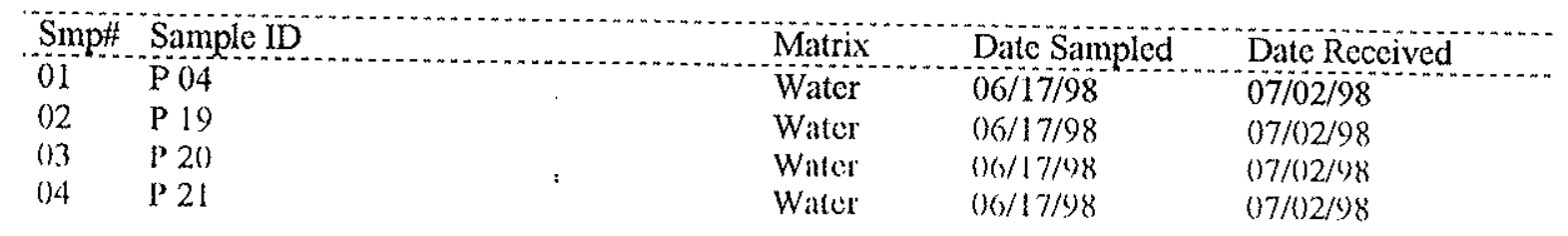

\begin{tabular}{|c|c|c|c|c|c|}
\hline Parameter & Units & $1 \ldots \ldots$ & 2 & $3 \ldots$ & 4. \\
\hline AMMONIA, AS N & $\mathrm{MG} / \mathrm{L}$ & $<0,40$ & 4.82 & $<0.40$ & $<0.40$ \\
\hline CHLORIDE & $\mathrm{MG} / \mathrm{L}$ & 38.2 & 47.9 & 15.6 & 33.1 \\
\hline NITRATE & $\mathrm{MG} / \mathrm{L}$ & 15.3 & 7.78 & 3.59 & 15.7 \\
\hline
\end{tabular}


General Chemistry Results

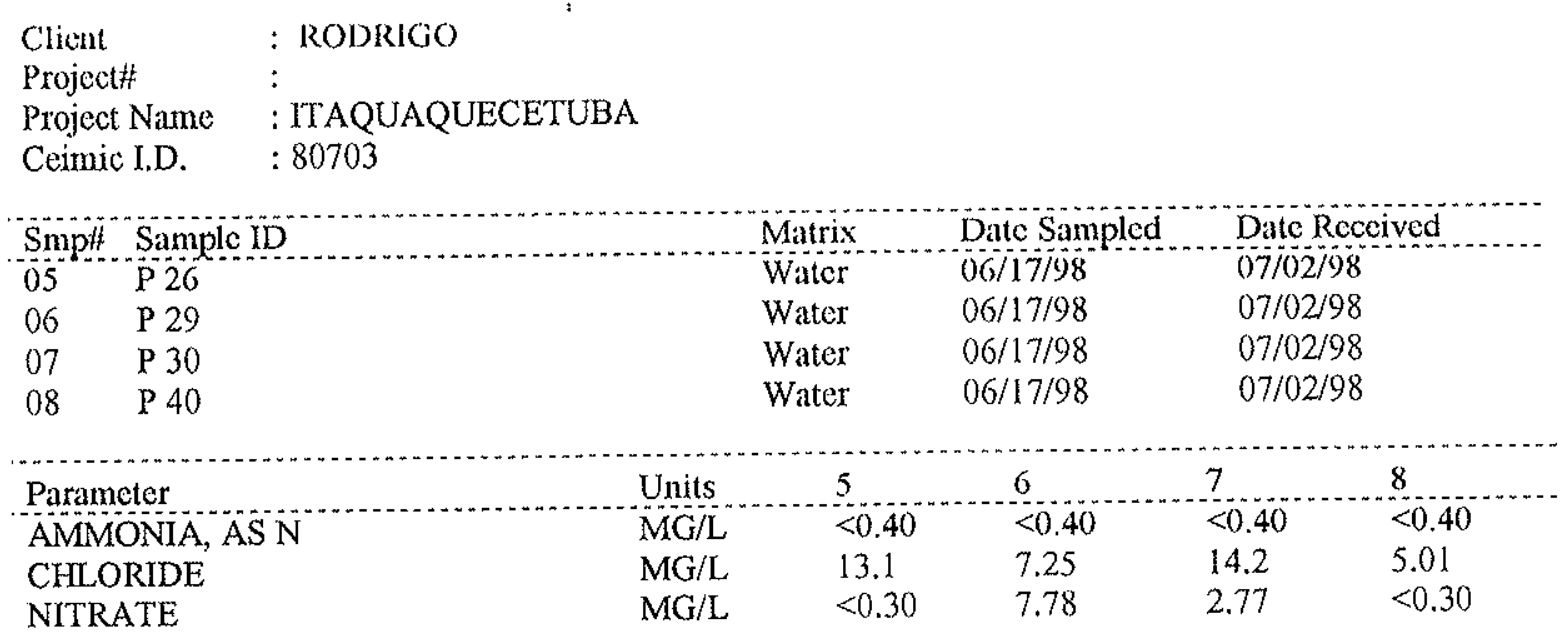

Rua Brigadeiro Galvão, 535-A Cep: 01151-000 - São Paulo - SP - Brasil Tel:. (011) 3667-0126 Fax: (011) 826-1429 _ e-mail: ceimic@8415.com.br 
General Chemistry Results

$\begin{array}{ll}\text { Clicnt } & : \text { RODRIGO } \\ \text { Project/ } & : \\ \text { Project Name } & : \text { ITAQUAQUECETUBA } \\ \text { Ceimic I.D. } & : 80703\end{array}$

\begin{tabular}{|c|c|c|c|c|}
\hline Smp & Sample ID & Matrix & Date Sampled & Date Received \\
\hline $09^{-4 n}$ & $\mathrm{p} 41$ & Water & $06 / 17 / 98$ & $07 / 02 / 98$ \\
\hline 10 & $P 42$ & Water & $06 / 17 / 98$ & $07 / 02 / 98$ \\
\hline 11 & P 44 & Water & $06 / 17 / 98$ & $07 / 02 / 98$ \\
\hline 12 & P 45 & Water & $06 / 17 / 98$ & $07 / 02 / 98$ \\
\hline
\end{tabular}

$\begin{array}{llllll}\text { Parameter } & \text { Units } & 9 & 10 & 11 & 12 \\ \text { AMMONIA, AS N } & \mathrm{MG} / \mathrm{L} & <0.40 & <0.40 & <0.40 & <0.40 \\ \text { CHLORIDE } & \mathrm{MG} / \mathrm{L} & 19.6 & 39.0 & 8.28 & 8.28 \\ \text { NITRATE } & \mathrm{MG} / \mathrm{L} & 22.1 & 14.6 & 10.4 & 1.79\end{array}$


Genemb Chemistry Resuls

$\begin{array}{ll}\text { Client } & \text { : RODRIGO } \\ \text { Project\# } & : \\ \text { Project Name } & : \text { ITAQUAQUECETUBA } \\ \text { Ccimic I.D. } & : 80703\end{array}$

\begin{tabular}{|c|c|c|c|c|}
\hline Smp杖 & Sample ID & Matrix & Date Sampied & Date Received \\
\hline 13 & $\mathrm{P} 46$ & Water & $06 / 17 / 98$ & $07 / 02 / 98$ \\
\hline 14 & P 49 & Water & $06 / 17 / 98$ & $07 / 02 / 98$ \\
\hline 15 & P 51 & Water & $06 / 17 / 98$ & $07 / 02 / 98$ \\
\hline 16 & CÓRREGO & Water & $06 / 17 / 98$ & $07 / 02 / 98$ \\
\hline
\end{tabular}

\begin{tabular}{|c|c|c|c|c|c|}
\hline Parameter & Units & 13 & 14 & 15 & 16 \\
\hline AMMONOA, $\mathrm{AS} N$ & $\mathrm{MG} / \mathrm{L}$ & $<0.40$ & 1.55 & $<0.40$ & 0.80 \\
\hline CHLORIDE & $\mathrm{MG} / \mathrm{L}$ & 7.63 & 26.8 & 5.45 & 11.3 \\
\hline NITRATE & $\mathrm{MG} / \mathrm{L}$, & 3.03 & 41.18 & 1.33 & 3.08 \\
\hline
\end{tabular}

Rua Brigadeiro Galvão, 535-A Cep: 01151-000 - São Paulo - SP - Brasil Tel:. (011) 3667-0126 Fax: (011) 826-1429 - c-mail: ceimic@8415.com.br 
General Chemistry Results

$\begin{array}{ll}\text { Client } & : \text { RODRIGO } \\ \text { Project } \# & : \\ \text { Project Name } & : \text { ITAQUAQUECETUBA } \\ \text { Ceimic L.D. } & : 80703\end{array}$

\begin{tabular}{|c|c|c|c|c|}
\hline SimpH & Sample 1D & Matrix & Date Sampled & Date Received \\
\hline $17^{-\cdots}$ & CORREGO 2 & Water & $06 / 17 / 98$ & $07 / 02 / 98$ \\
\hline 18 & FOSSA & Water & $06 / 17 / 98$ & 07/02/98 \\
\hline
\end{tabular}

\begin{tabular}{|c|c|c|c|}
\hline Paramcter & Units. & 17 & 18 \\
\hline AMMONIA, AS N & $\mathrm{MG} / \mathrm{L}$ & 1.62 & 758 \\
\hline CHLORIDE & $\mathrm{MG} / \mathrm{L}$ & 10.9 & 257 \\
\hline NITRATE & $\mathrm{MG} / \mathrm{L}$ & 4.00 & 2.40 \\
\hline
\end{tabular}


General Chemistry - Quality Control Report Blank/Blank Spike

$\begin{array}{ll}\text { Clicnt } & \text { : RODRIGO } \\ \text { Projecll } & : \\ \text { P'roject Name } & : \text { I'AQUAQUECETUBA } \\ \text { Ceimic L.D. } & : 80703\end{array}$

$\begin{array}{llllll}\text { Parametcr } & \text { Units } & \text { Blank } & \text { Spiked } & \text { Spike } & \% \text { Rec. } \\ & & \text { Restalt } & \text { Sample } & \text { Conc. } & \\ \text { AMMONIA, AS N } & \mathrm{MG} / \mathrm{L} & <0.40 & 0.89 & 1.00 & 89 \\ \text { CHLORIDE } & \mathrm{MG} / \mathrm{L} & <2.00 & 80.3 & 81.2 & 99 \\ \text { NITRATE } & \mathrm{MG} / \mathrm{L} & <0.30 & 4.24 & 4.00 & 106\end{array}$

$\%$ Recovery $=(\text { Spike Sample Result }- \text { Sample Result })^{\text {tw }} 100 /$ Spike Concentantion 


\section{Gencral Chemistry - Quality Control Report \\ Duplicate/Matrix Spike}

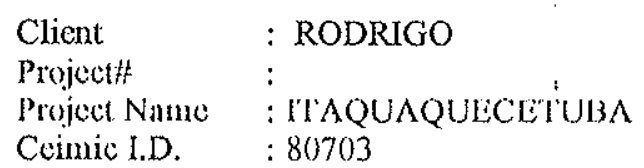

\begin{tabular}{|c|c|c|c|c|c|c|c|c|}
\hline Parameter & Ref. I.D. & Units & $\begin{array}{l}\text { Sample } \\
\text { Resull }\end{array}$ & $\begin{array}{l}\text { Dup } \\
\text { Result }\end{array}$ & $\begin{array}{l}\text { RPD } \\
\%\end{array}$ & $\begin{array}{l}\text { Spiked } \\
\text { Samplc }\end{array}$ & $\begin{array}{l}\text { Spike } \\
\text { Conc. }\end{array}$ & $\% \operatorname{Rec}$. \\
\hline AMMONIA, AS N & $80702-02$ & $\mathrm{MG} / \mathrm{L}$ & $1.80^{-1}$ & 1.48 & 20 & 2.55 & 1.00 & 75 \\
\hline CHLORIDE & $80628 m 02$ & $\mathrm{MG} / \mathrm{L}$ & 5.35 & 5.35 & 0 & 90.0 & 86.7 & 98 \\
\hline NITRATE & $80703-05$ & $\mathrm{MG} / \mathrm{L}$ & $<0.30$ & $<0.30$ & 0 & 4.06 & 4.00 & 102 \\
\hline
\end{tabular}

\%Recovery = (Spike Sample Result - Sample Result) $100 /$ Spike Concentration RPD (Relative \% Difference) $=(\text { Sample Result }- \text { Duplicate Result })^{*} 100 /$ Average Restult 
ANEXO D

ANEXO FOTOGRÁFICO 


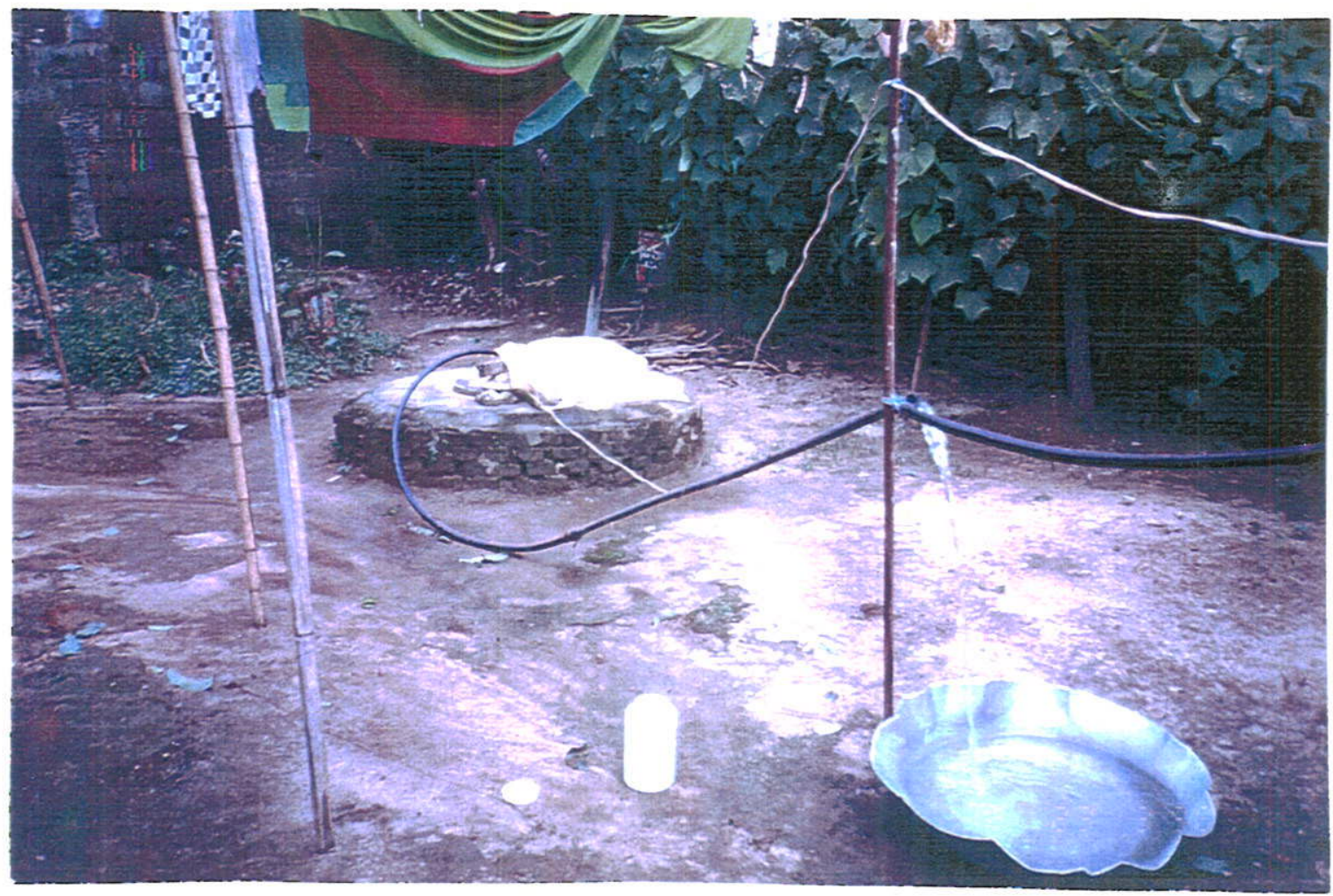

Fotografia 01 - Coleta de água no poço 40 (montante), através de bomba 


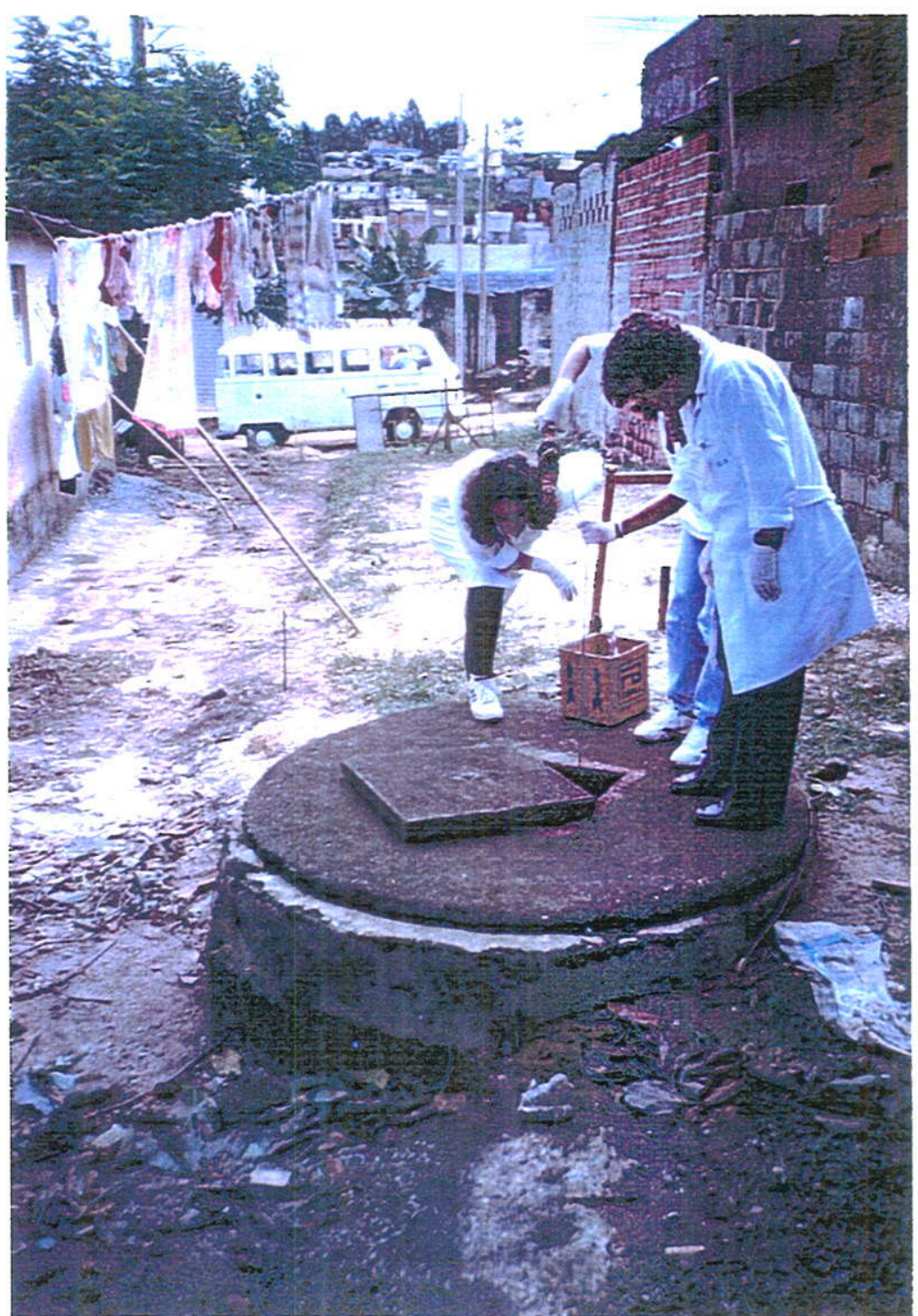

Fotografia 02 - Coleta de água no poço 41 (posição intermediária), através de coletor esterilizado 


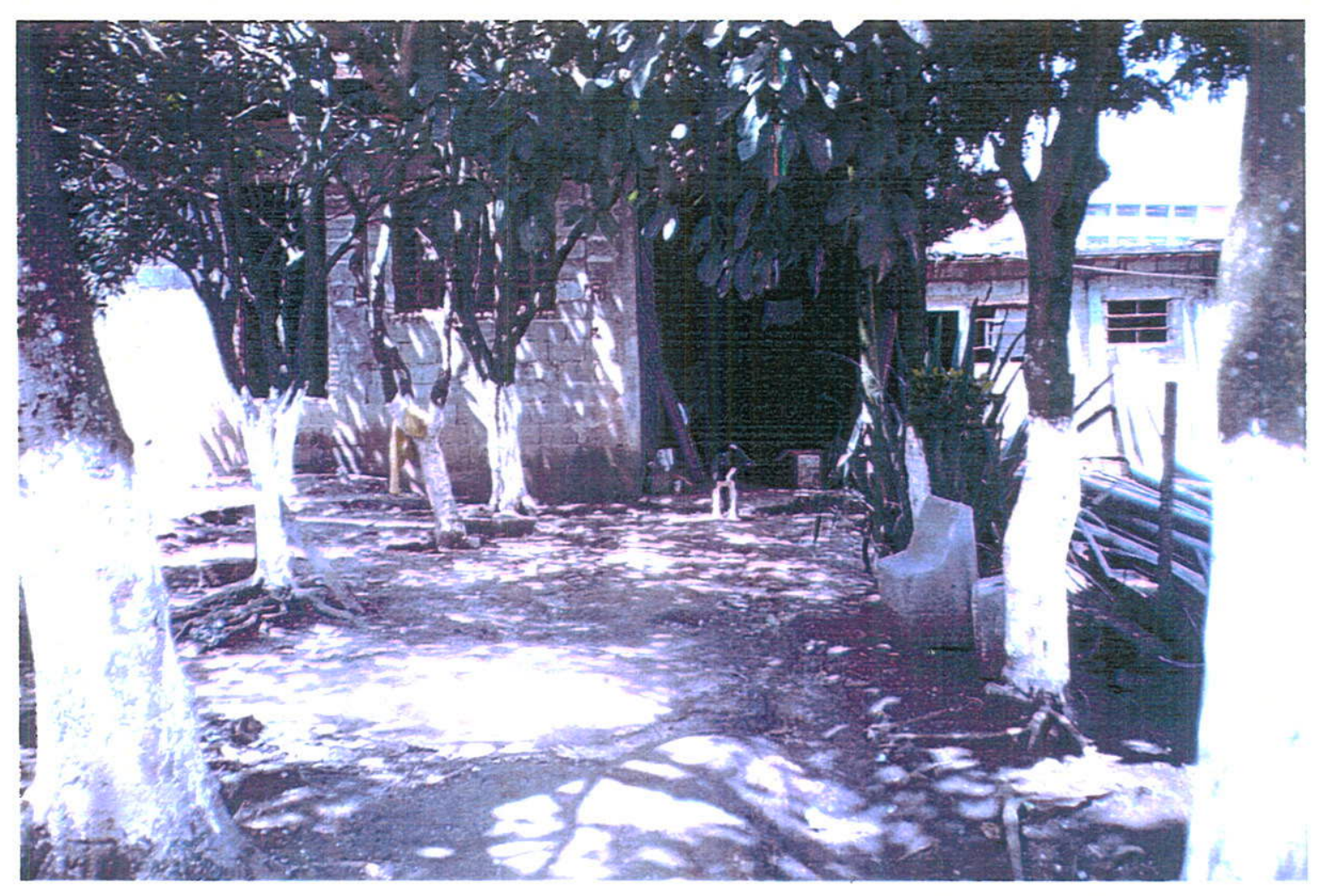

Fotografia 03 - Residência onde se localiza o poço 42 (ao fundo, posição jusante) 


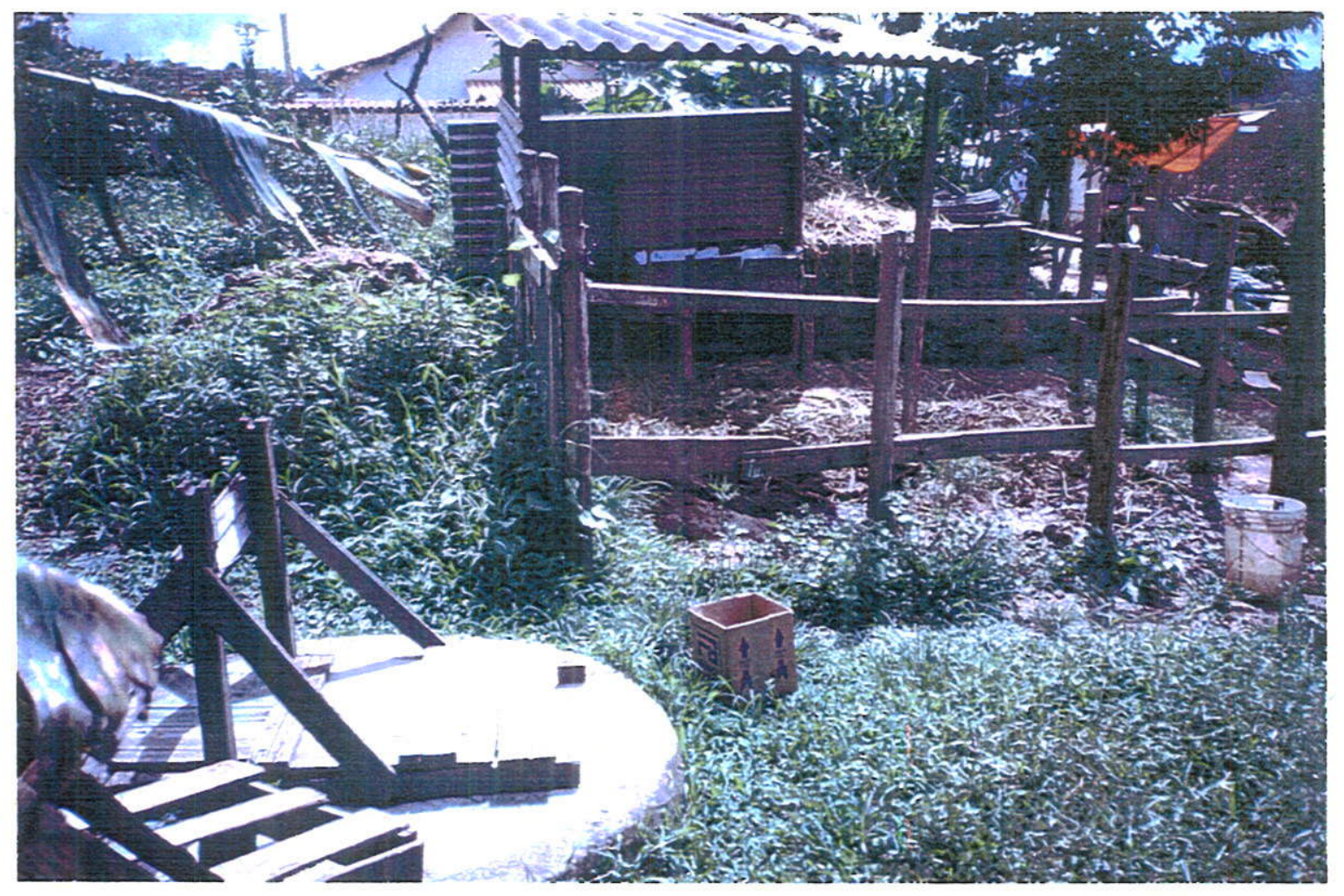

Fotografia 04 - Poço 44 (montante), onde, ao lado, existe uma criação de cavalos 




Fotografia 05 - Coleta de água manual, através de balde ( $P$ 44) 


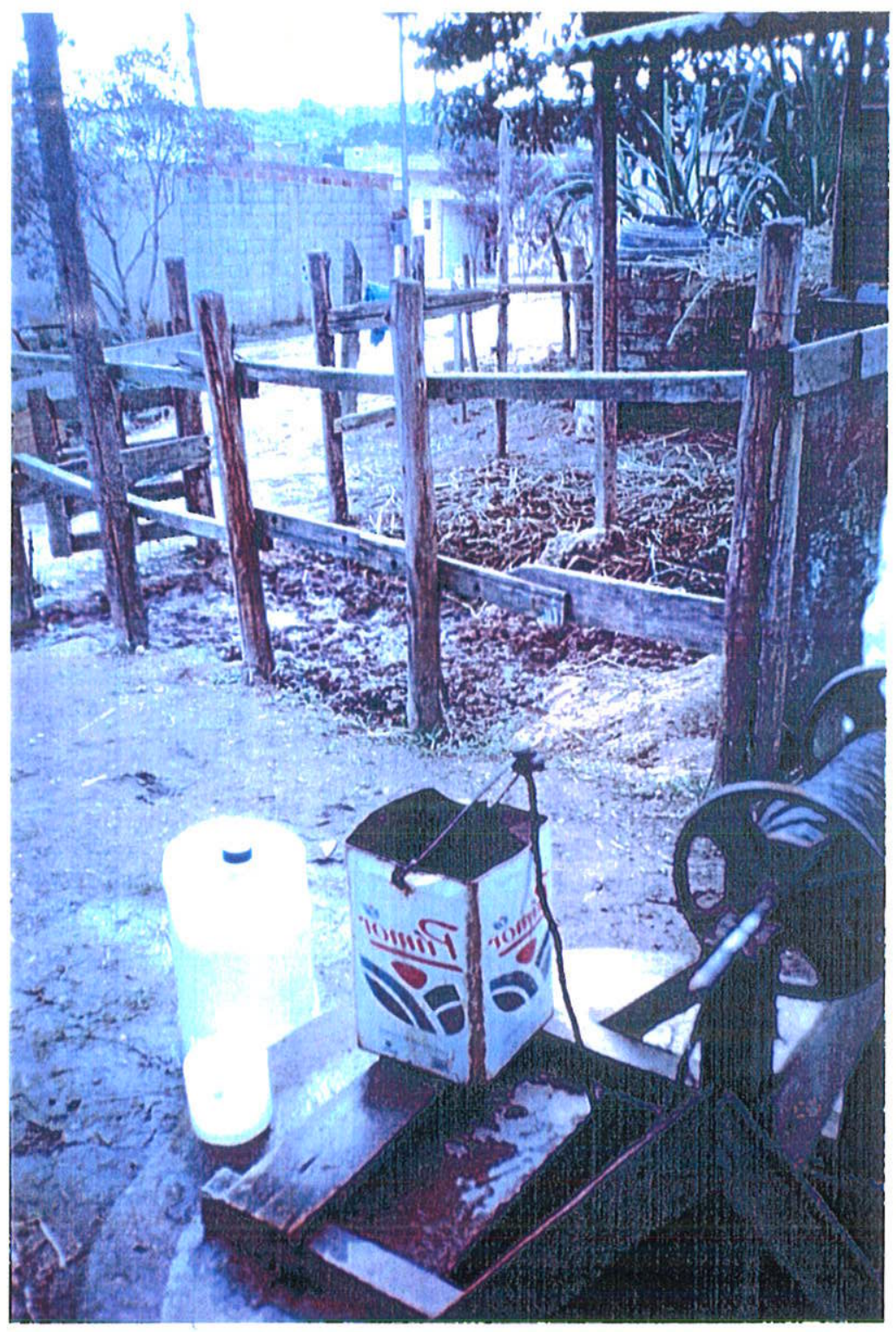

Fotografia 06 - Coleta de amostra de água para análise de Cryptosporidium (P 44) 


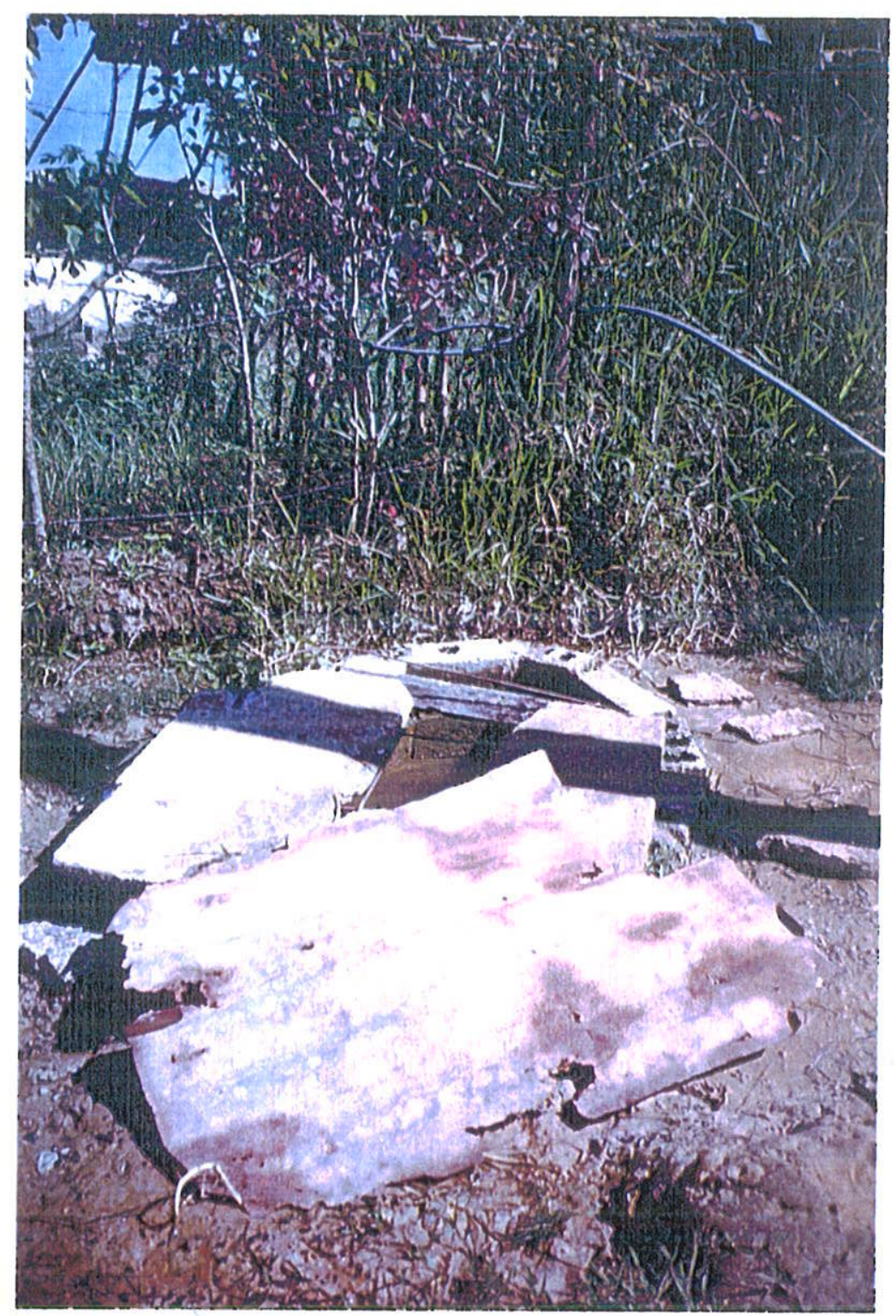

Fotografia 07 - P 45, em condições sanitárias precárias 


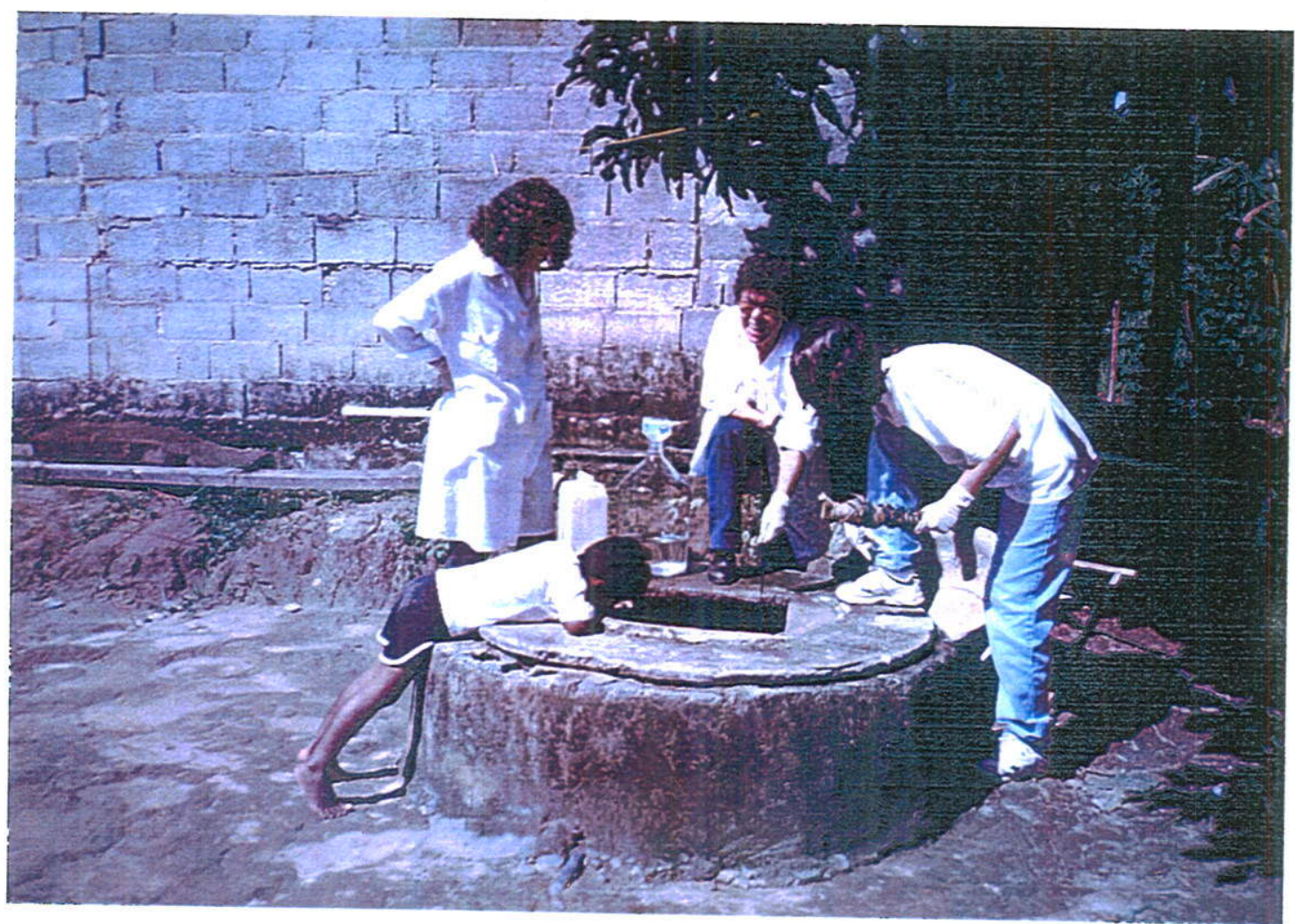

Fotografia 08 - Coleta de água no poço 46 (jusante), através de coletor esterilizado 


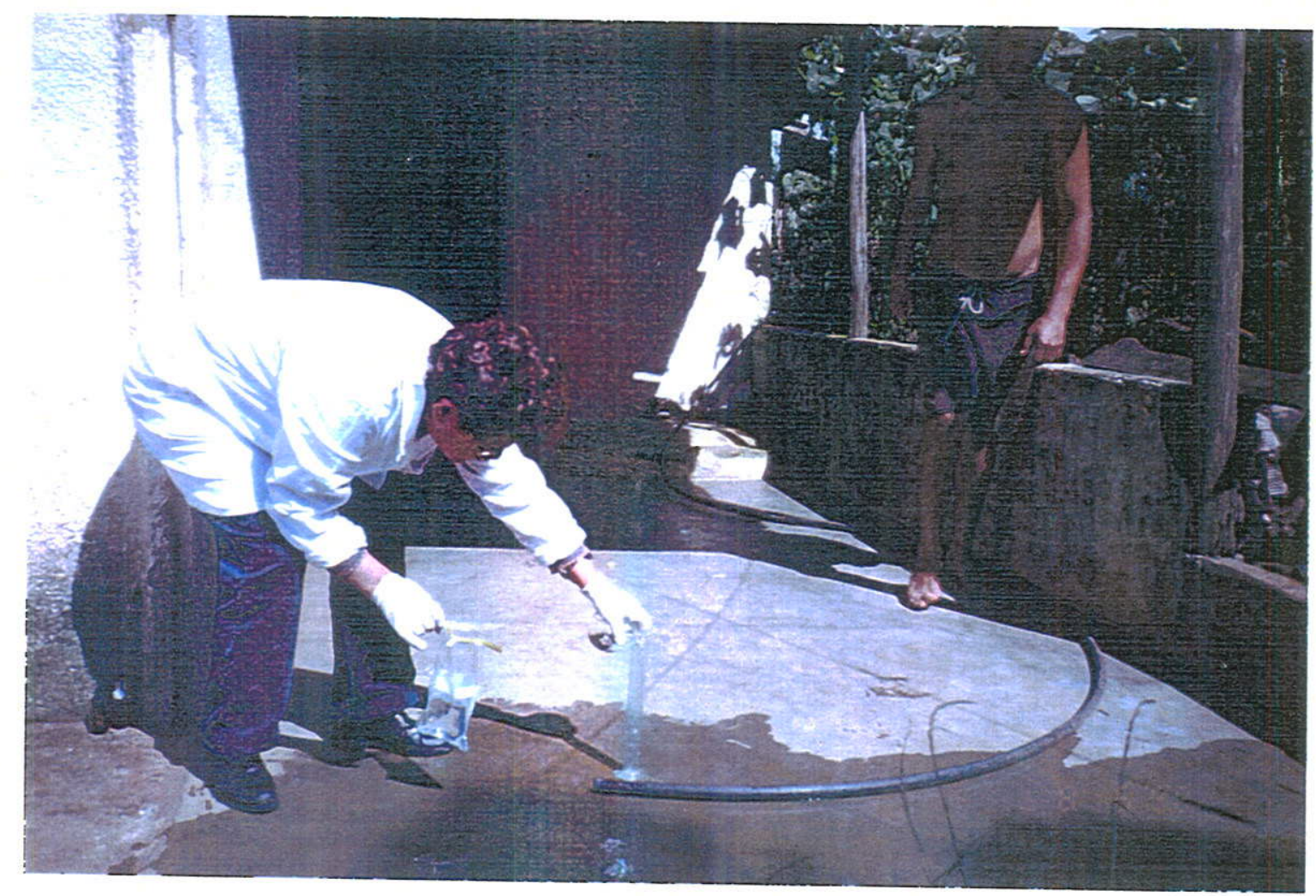

Fotografia 09 - Coleta de água no poço 51 (montante), através de bomba (amostra para análise de coliformes e para teste de alcalinidade) 


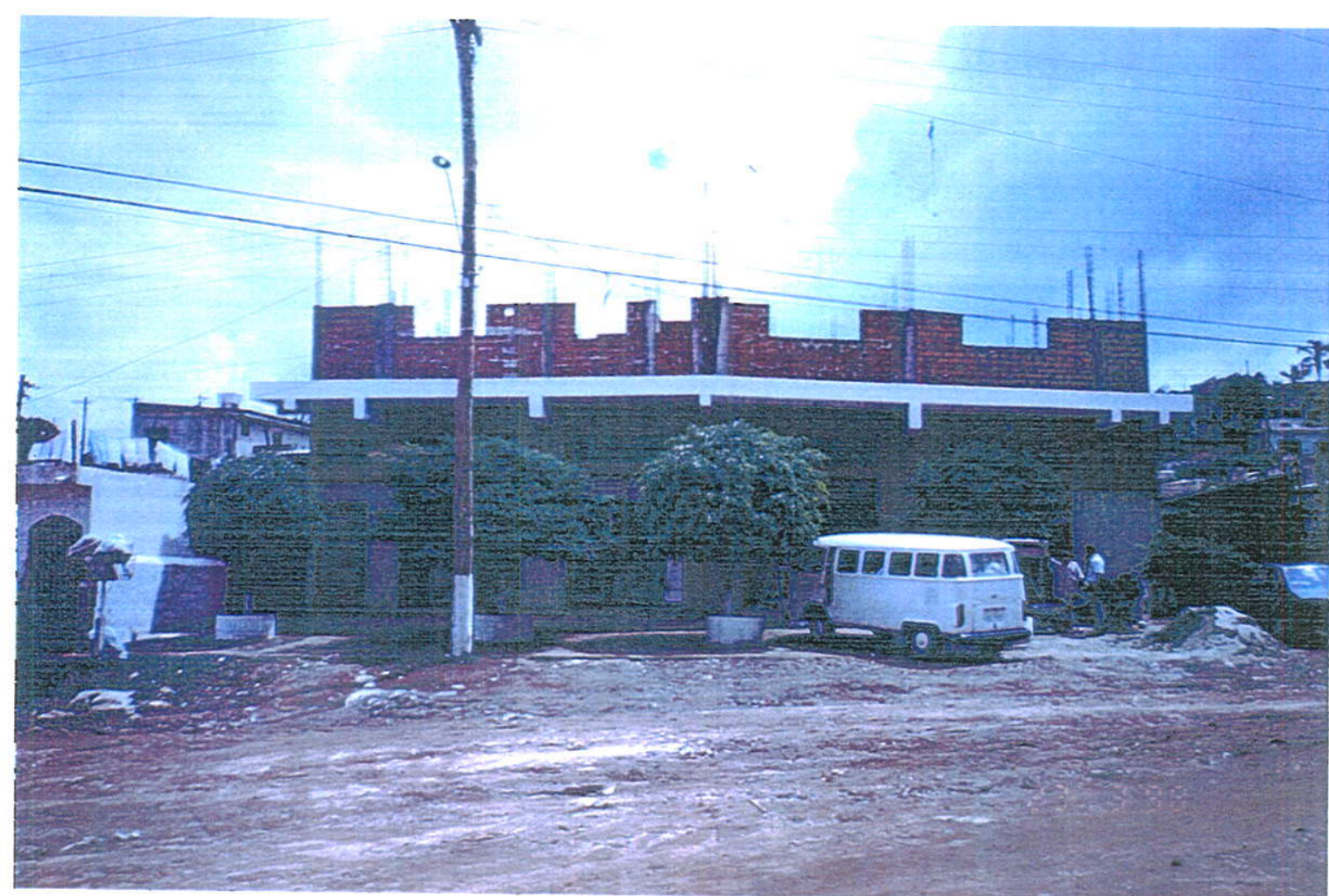

Fotografia 11 - Estabelecimento comercial (padaria), onde está localizado o poço 04 (jusante) 


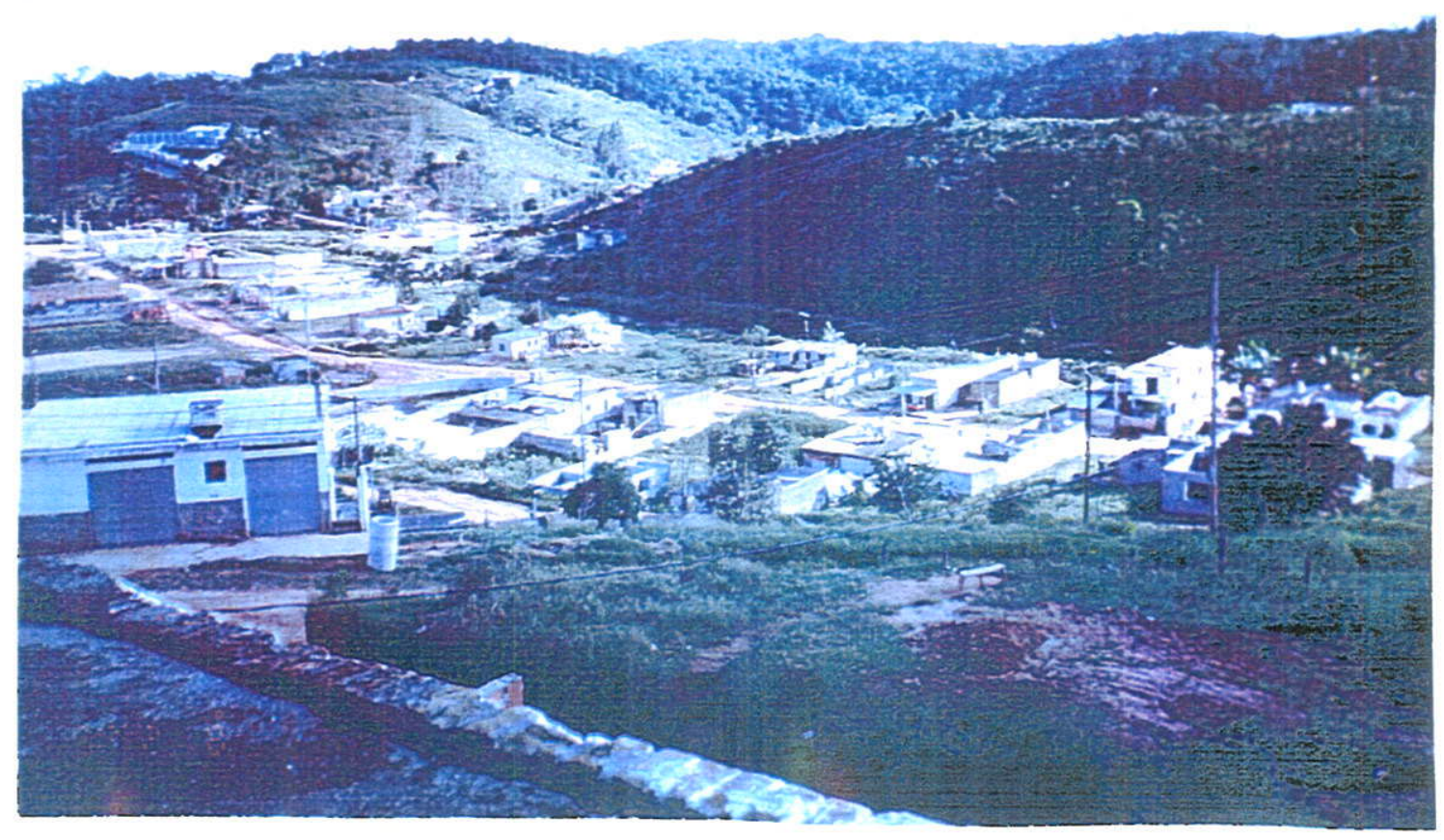

Fotografia 12 - Visão geral do extremo norte do bairro, menos povoado, vertente dos poços 21-20-19 


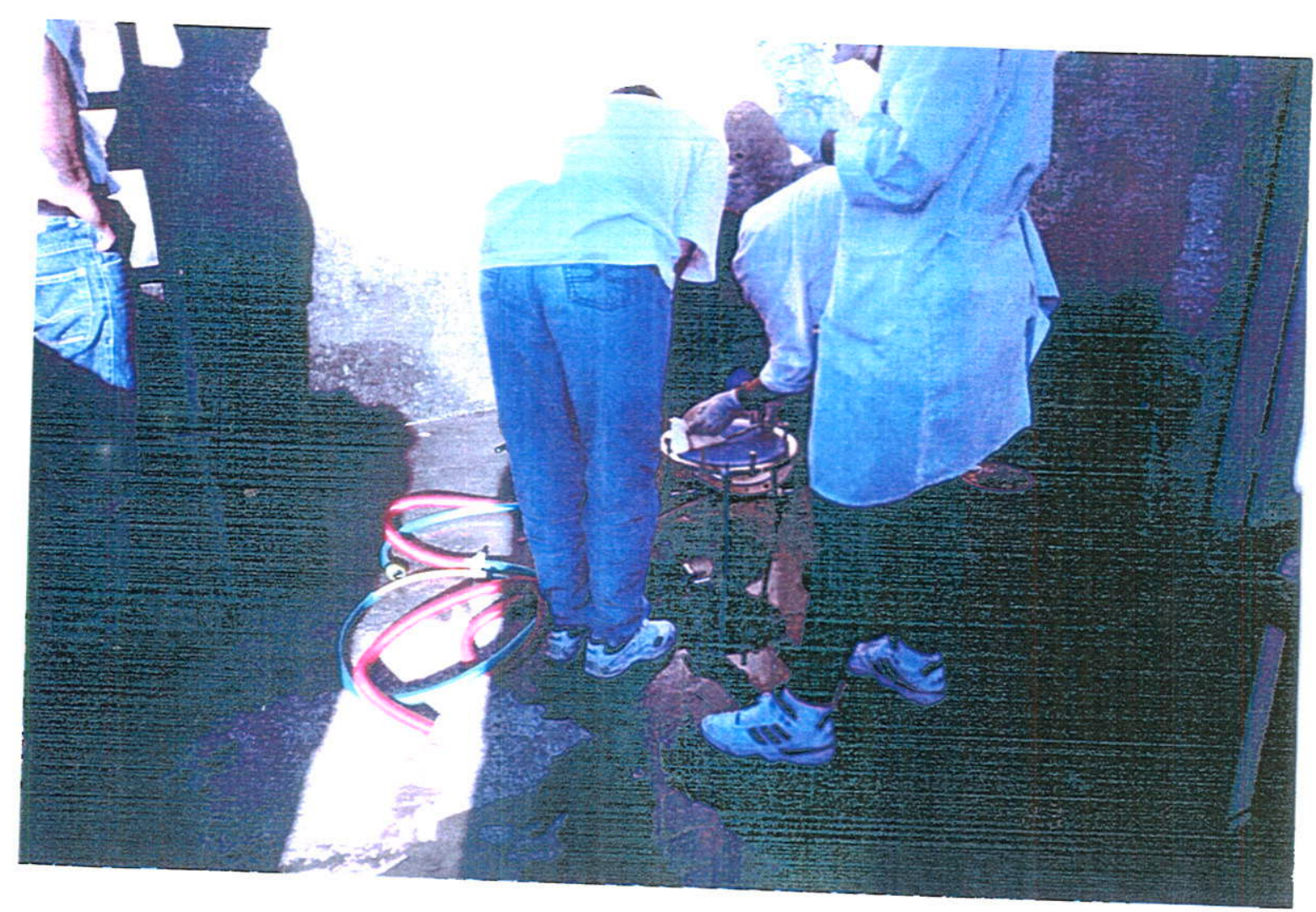

Fotografia 13 - Coleta de água para análises de Cryptosporidium (P 19, jusante) 


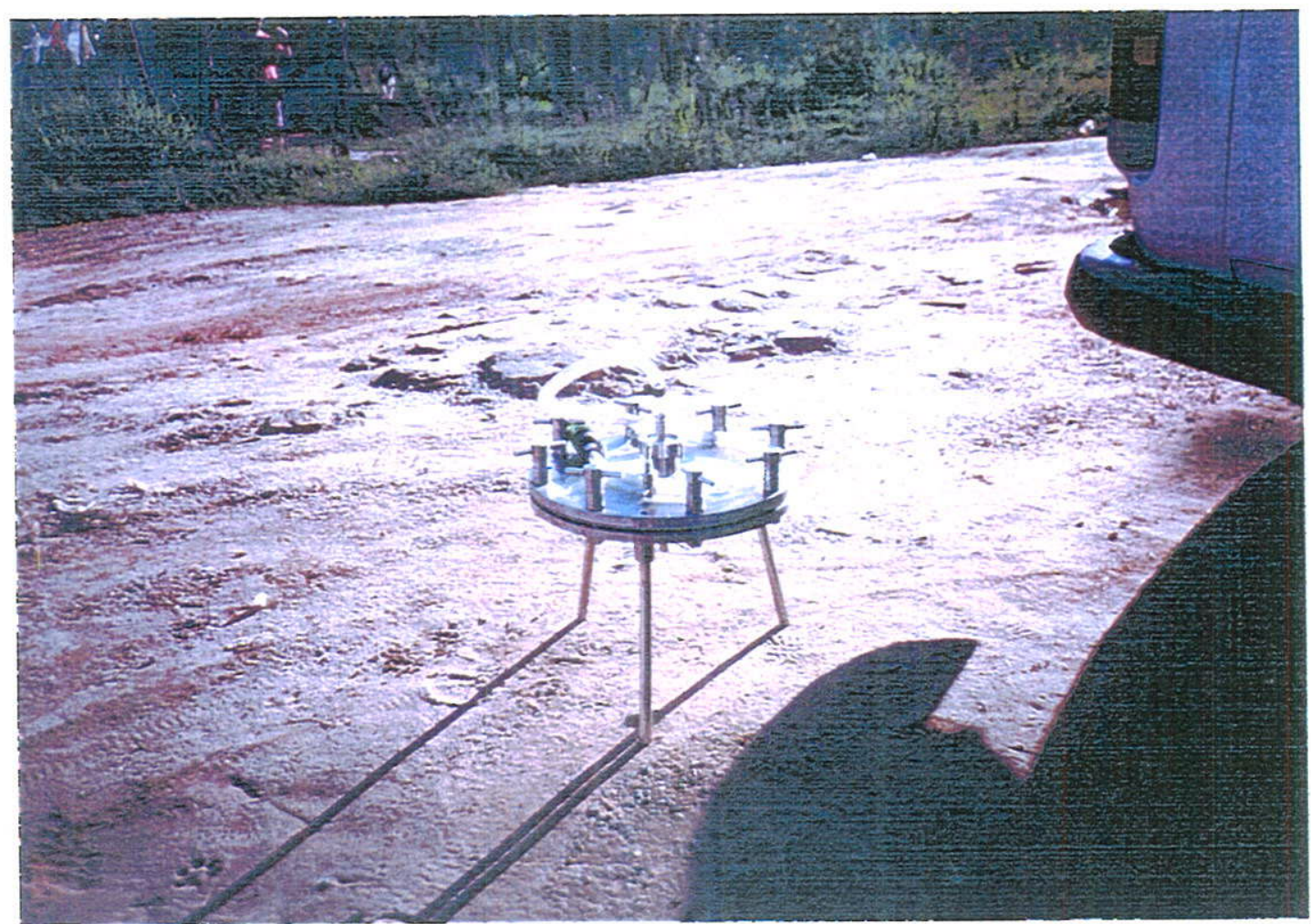

Fotografia 14 - Detalhe do suporte para filtragem de oocistos de Cryptosporidium 


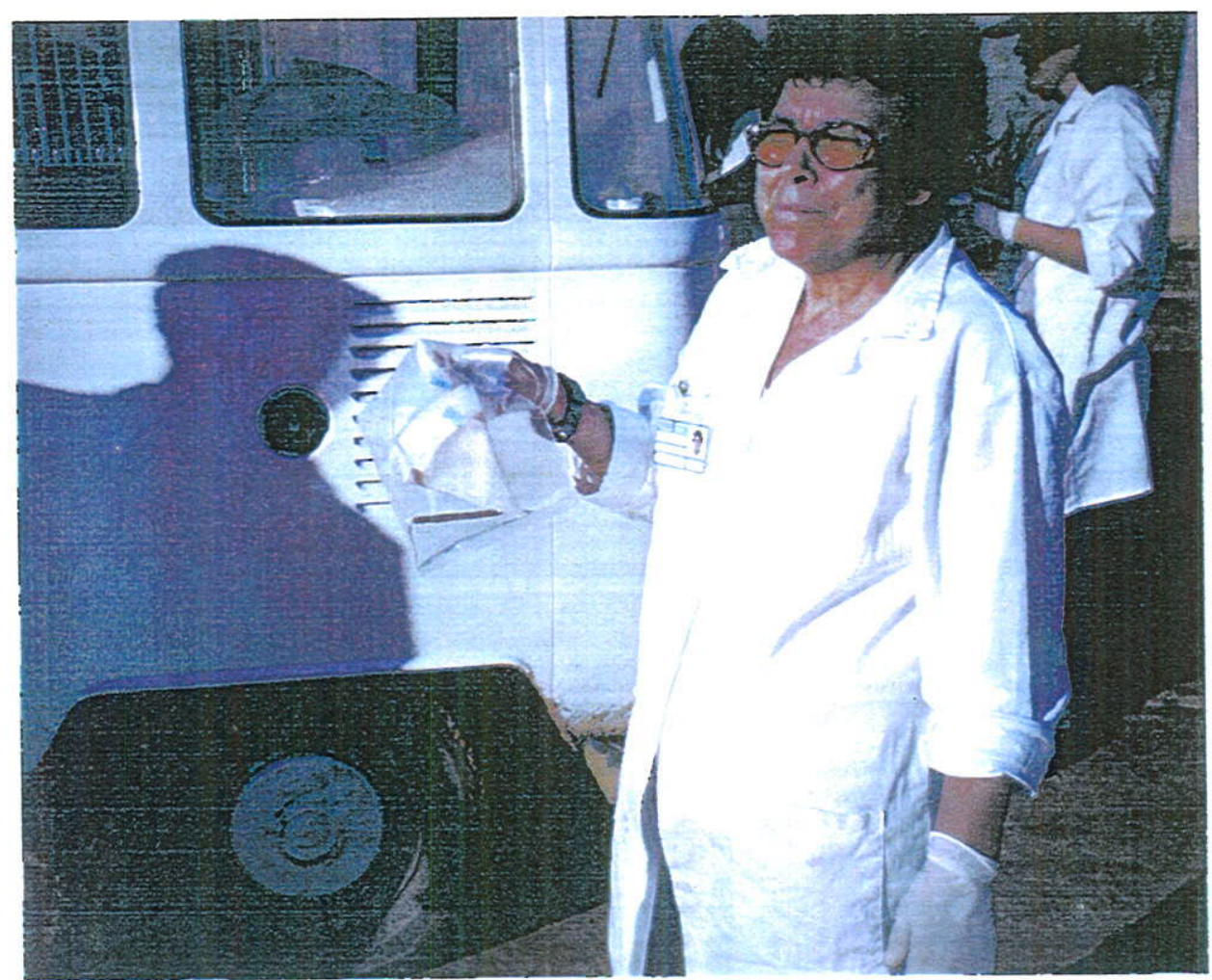

Fotografia 15 - Armazenamento do filtro utilizado para retenção de oocistos de Cryptosporidium 


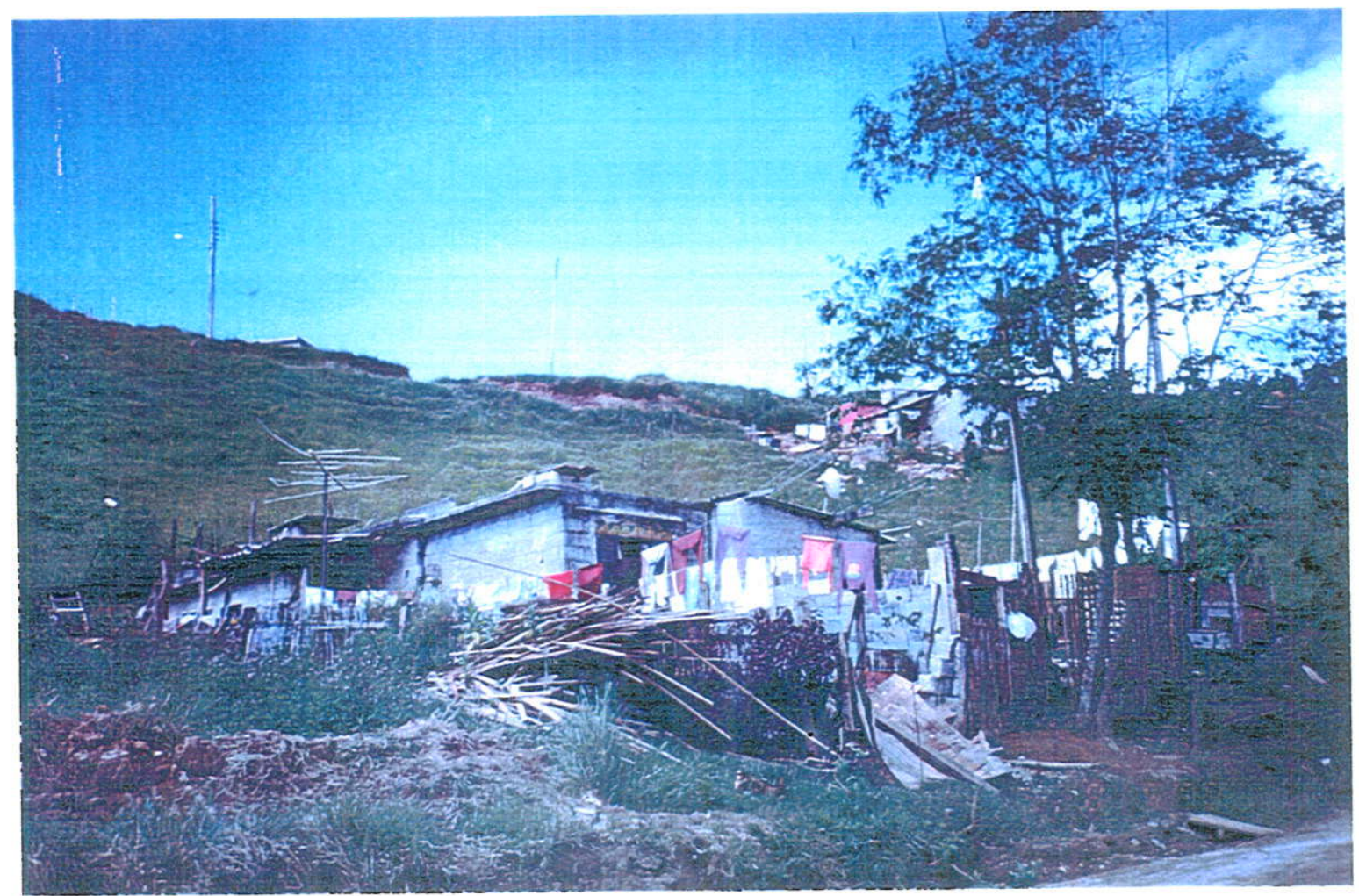

Fotografia 16 - Residência onde está localizado o P 29 (posição intermediária). Condições precárias de moradia 


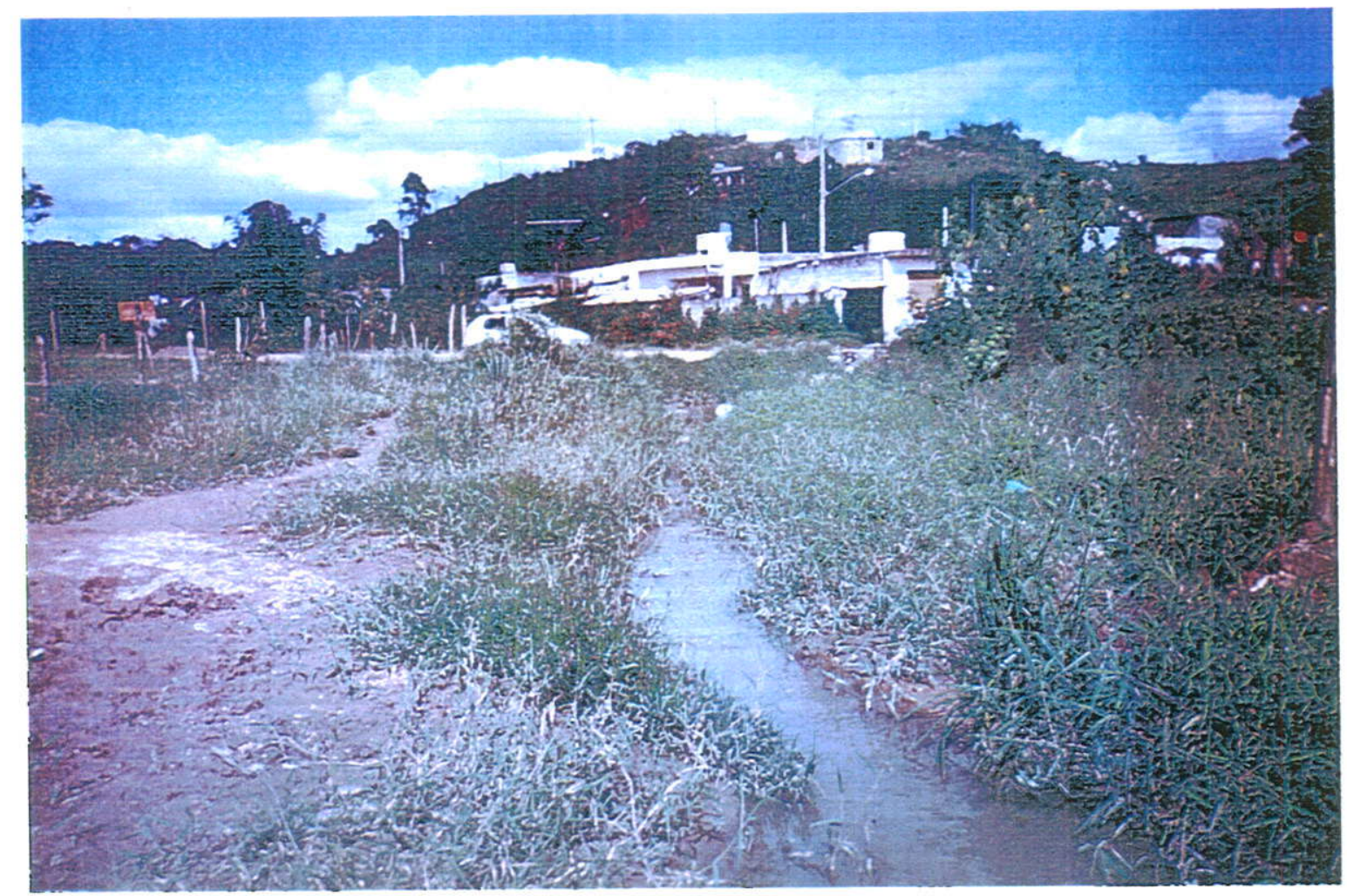

Fotografia 17 - Local de coleta de água superficial (Córrego 1) 


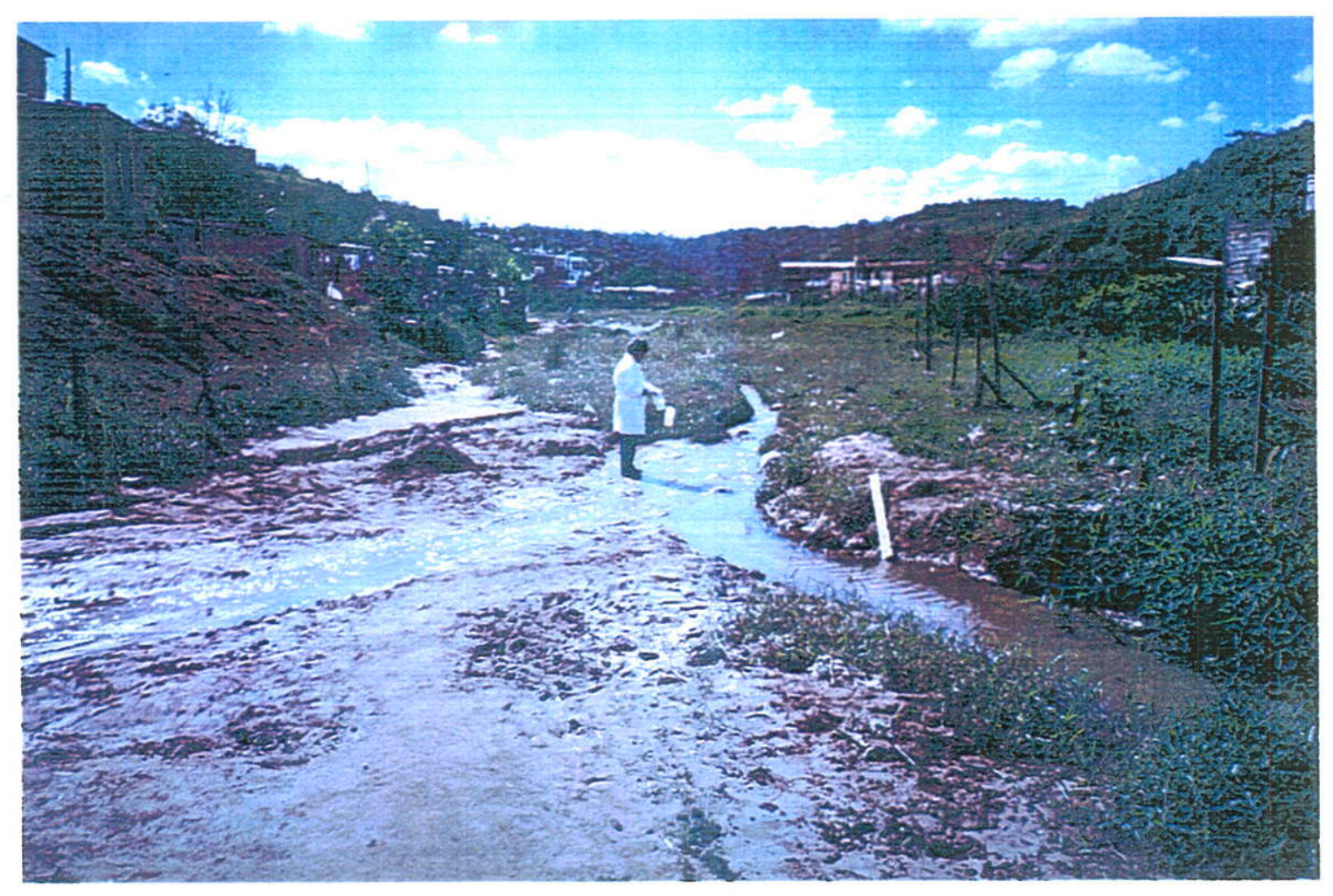

Fotografia 18 - Local de coleta de água superficial (Córrego 2) 


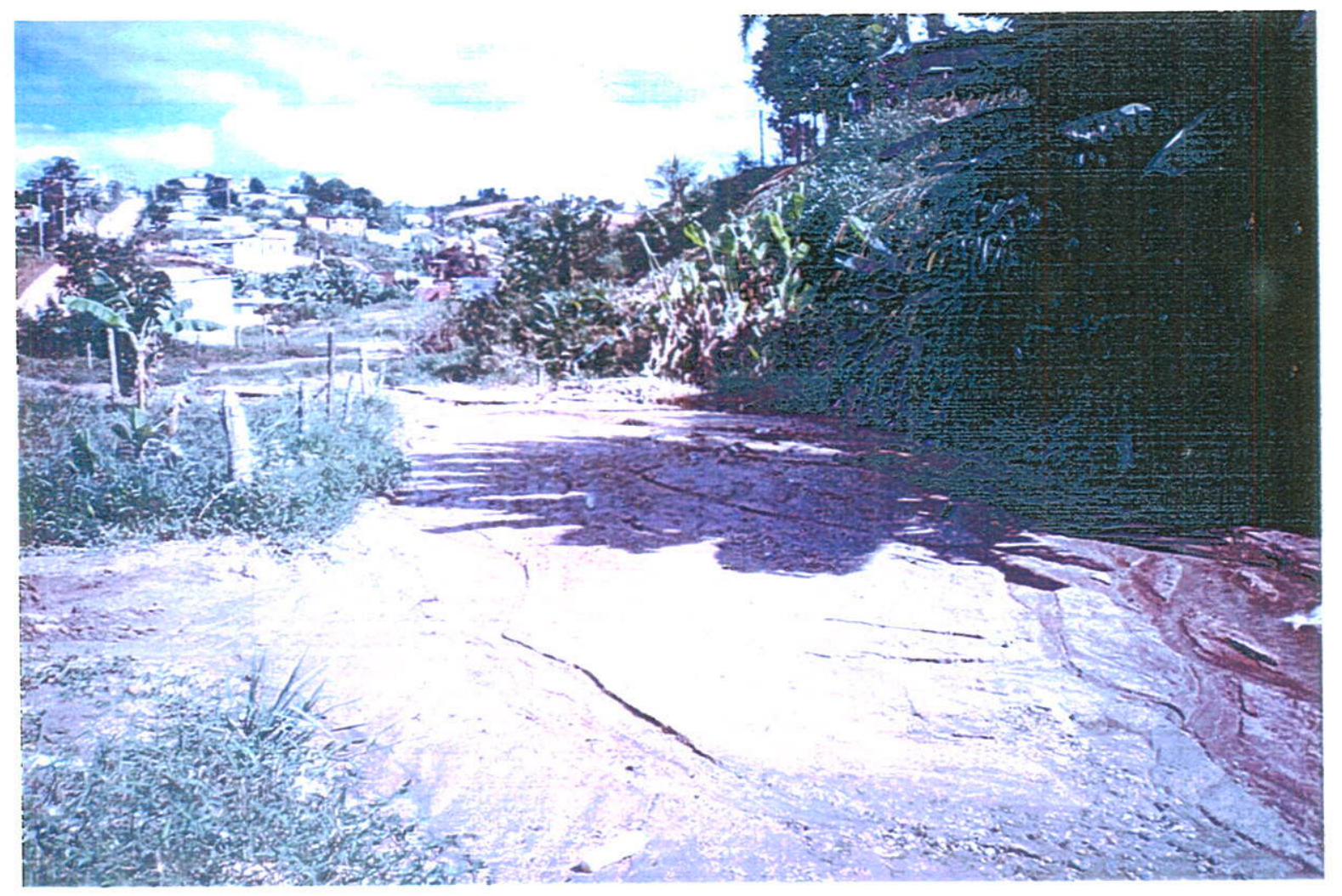

Fotografía 19 - Córrego afluente ao Córrego 2. Notar assoreamento de seu leito em função da ocupação desordenada do solo montante 


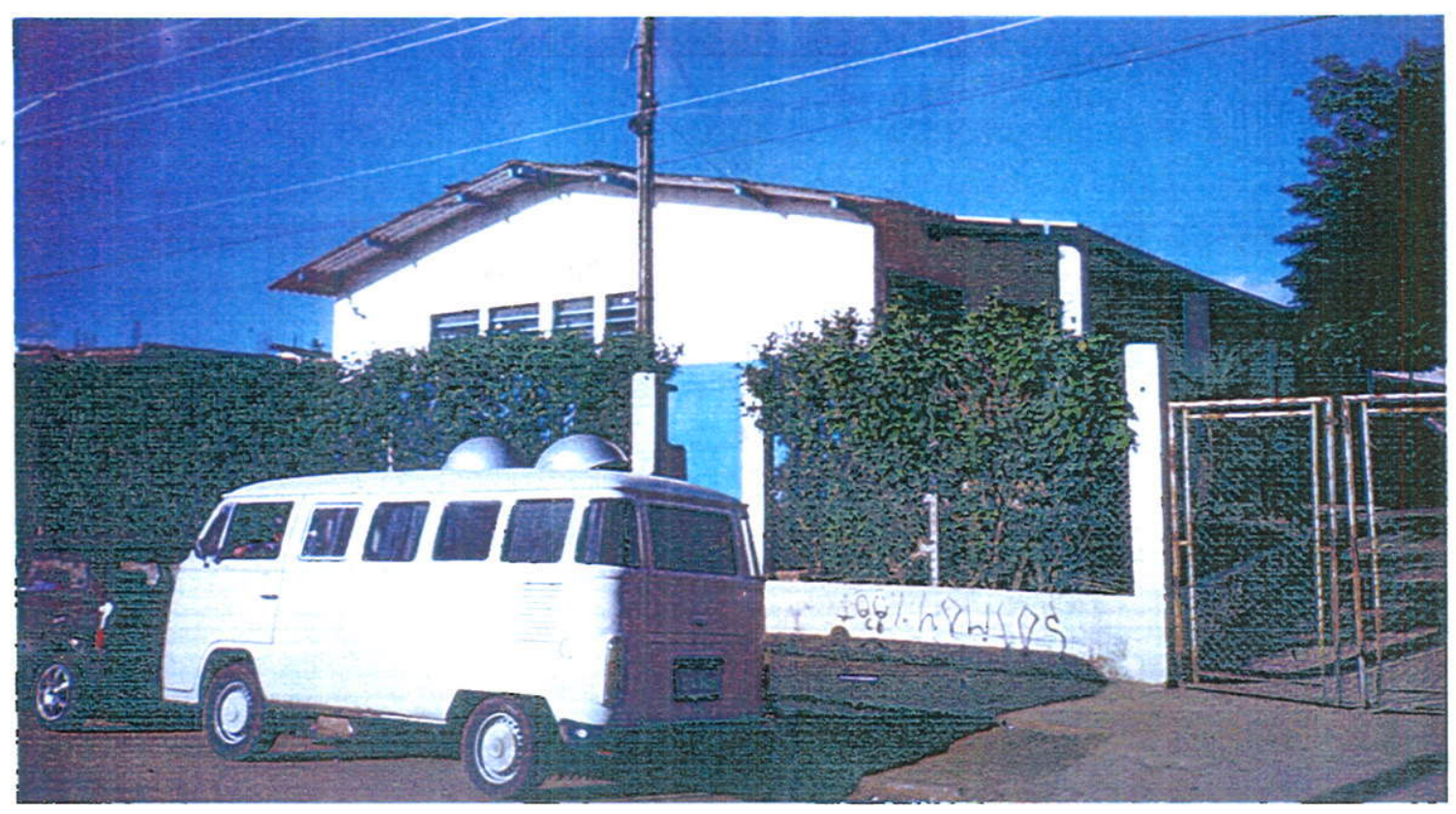

Fotografia 20 - Posto de Saúde do bairro Recanto Mônica 


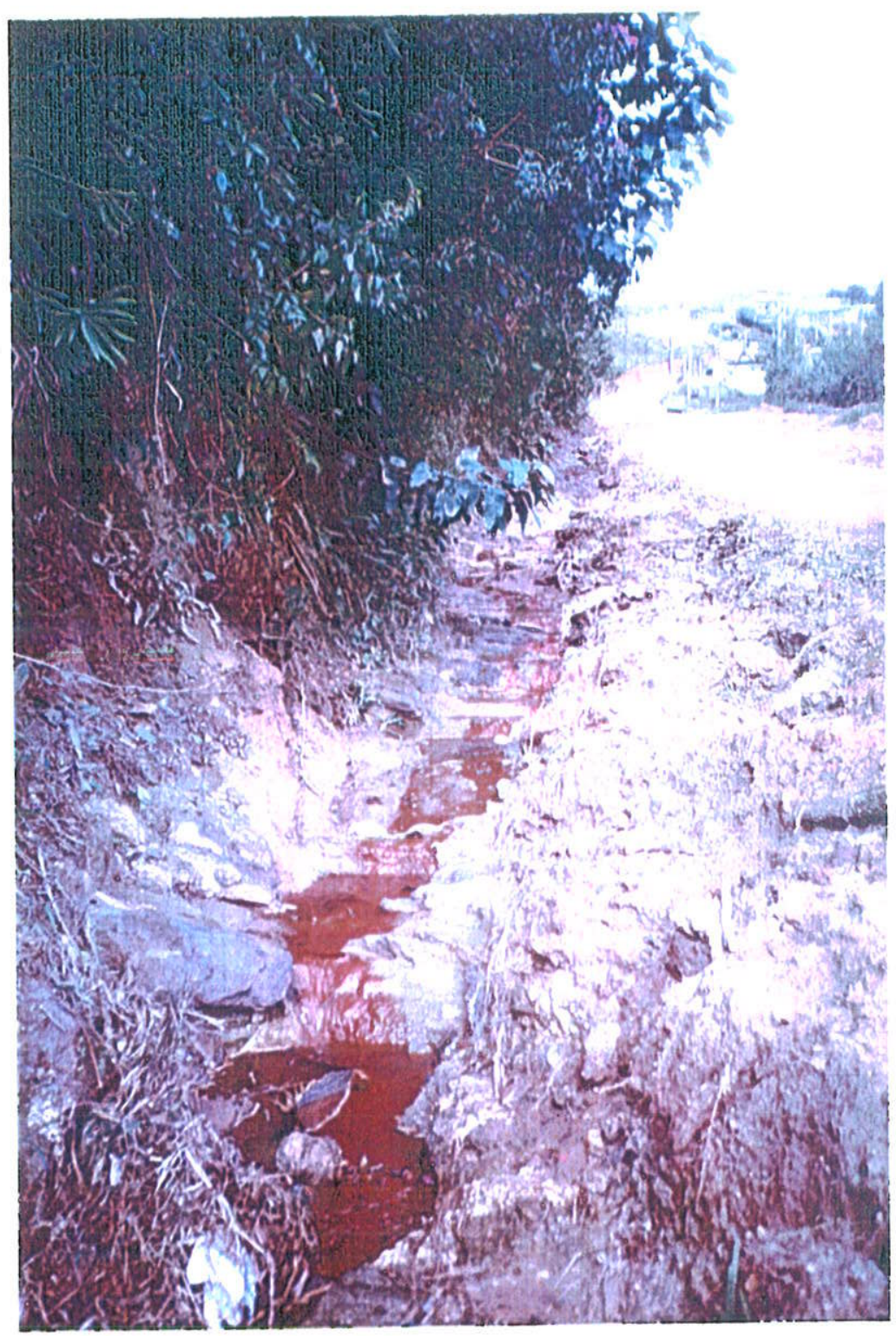

Fotografia 21 - Exposição de rocha alterada (no local também corre esgoto a céu aberto) 


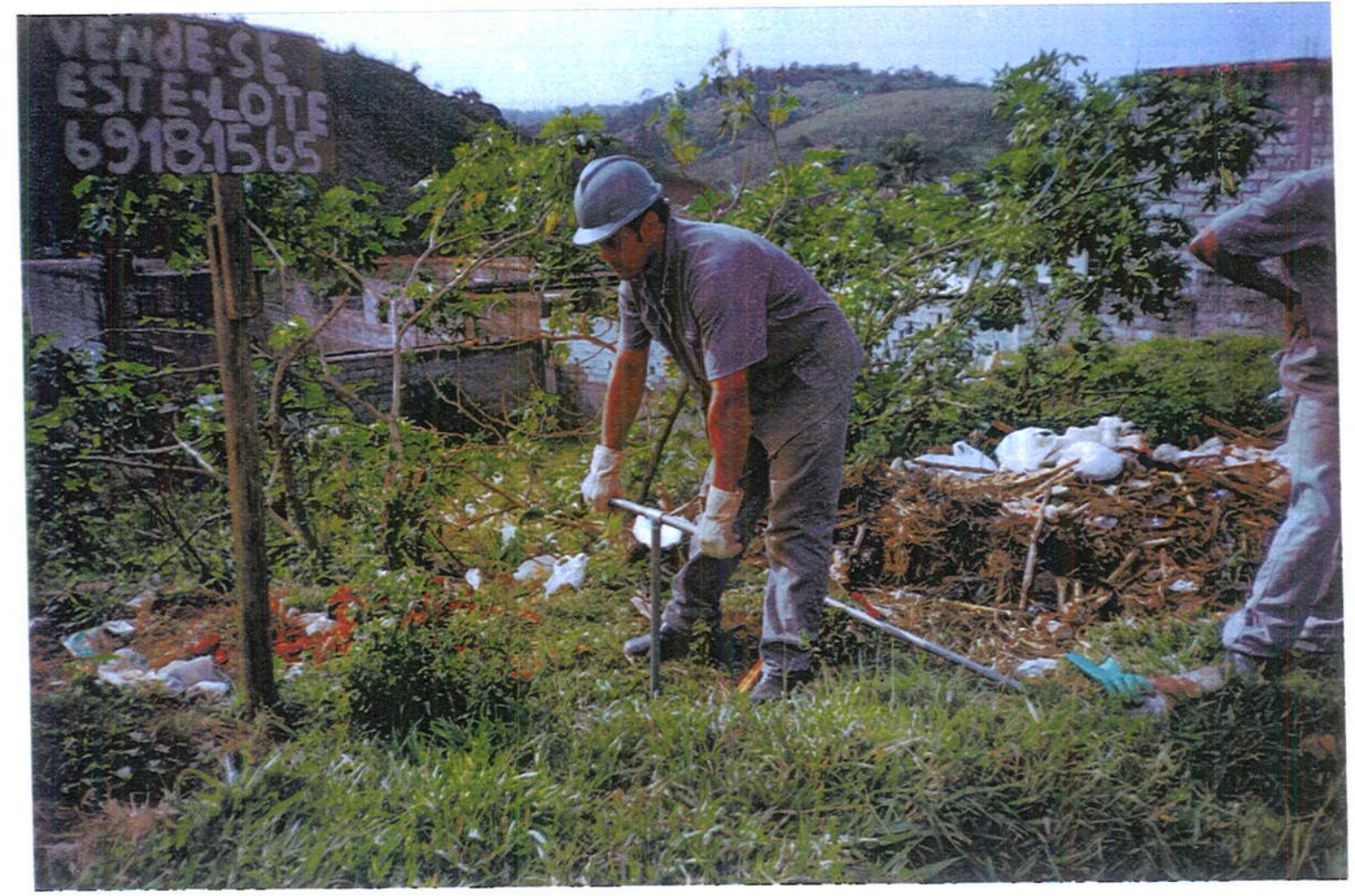

Fotografia 22 - Sondagem a trado (ST 21) 


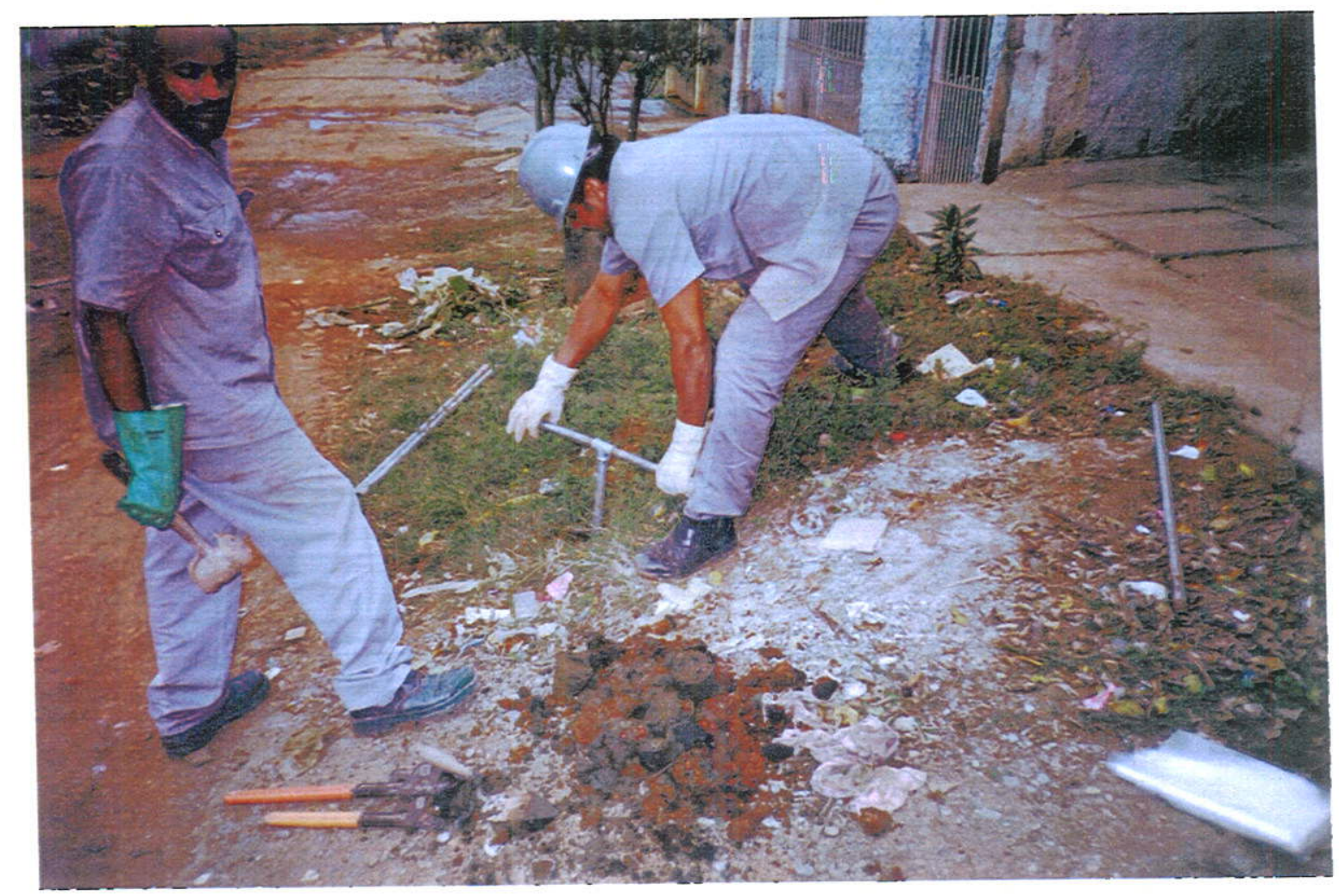

Fotografia 23 - Sondagem a trado (ST 04) 


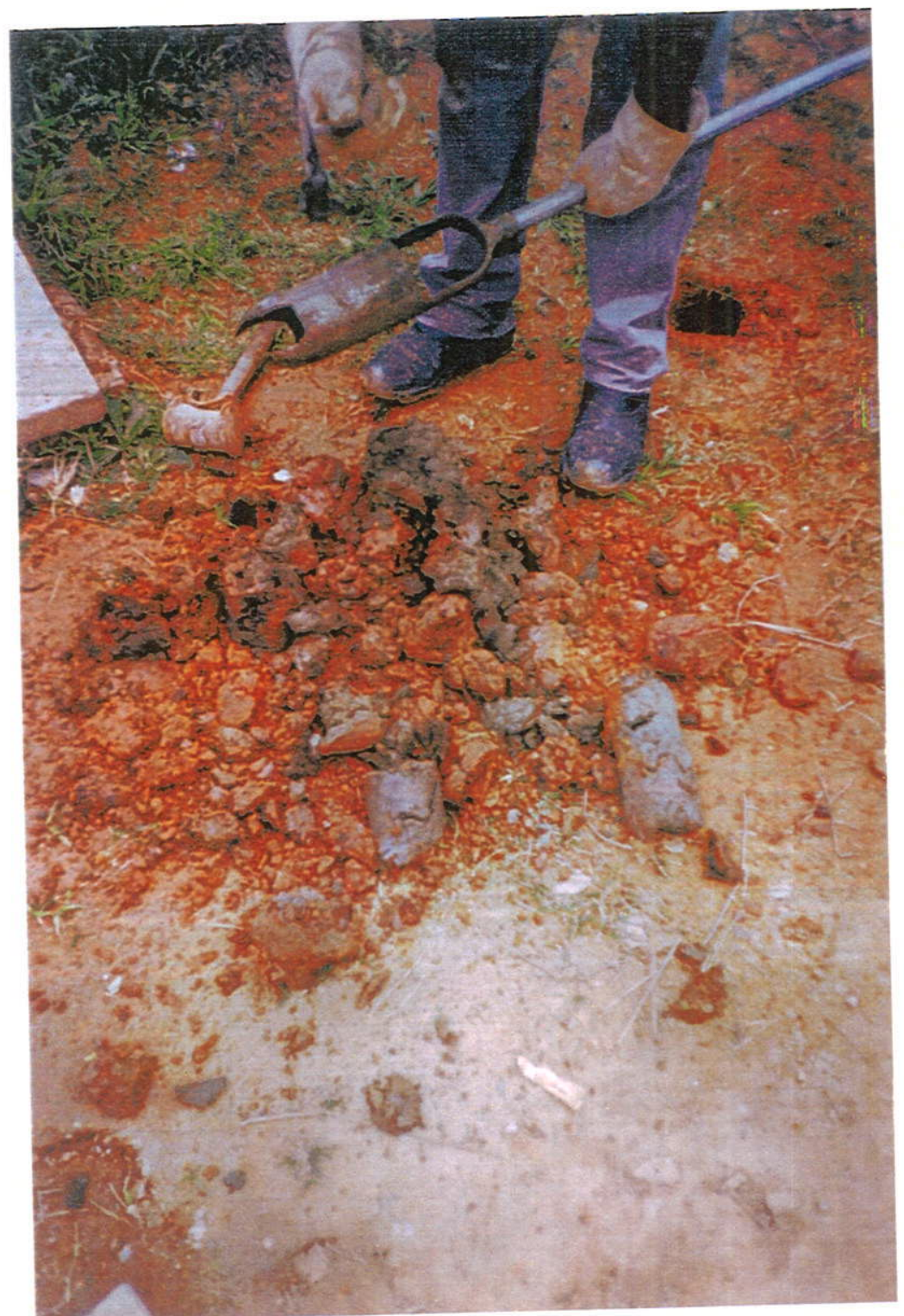

Fotografia 24 - Detalhe do solo com evidência de contaminação (influência da água subterrânea contaminada) 